
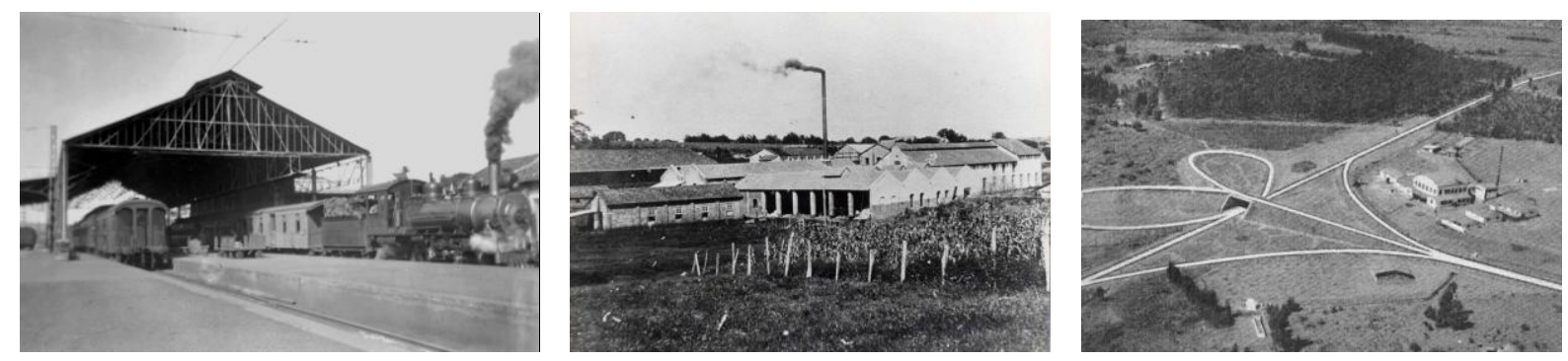

\title{
INDUSTRIALIZAÇÃO E URBANIZAÇÃO EM SÃO CARLOS NAS DÉCADAS DE 1930 A 1960
}

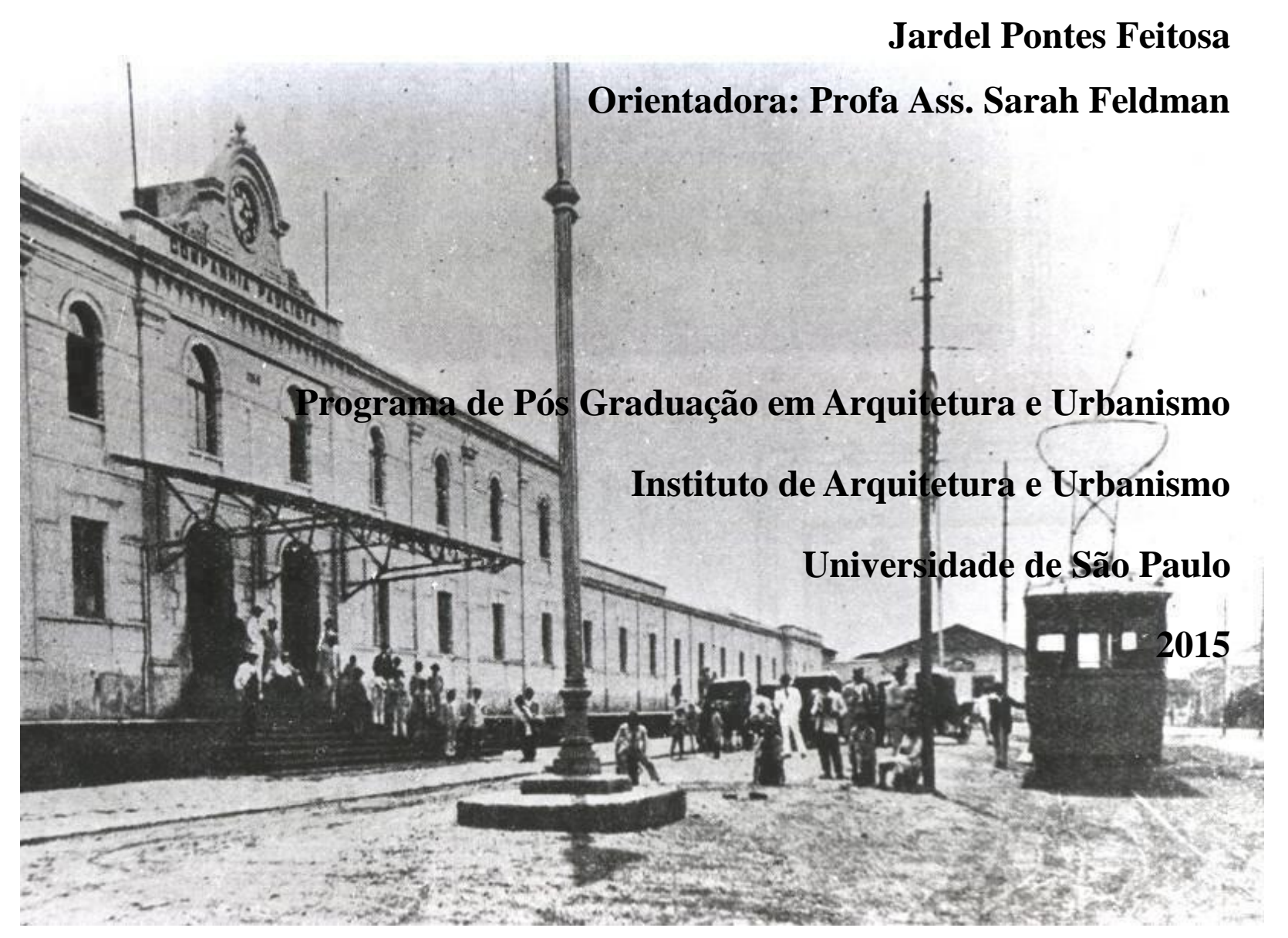


FOLHA DE JULGAMENTO

Candidato: Licenciado em Geografia Jardel Pontes Feitosa.

Título da dissertação: "Industrialização e Urbanização em São Carlos nas décadas de 1930 a $1960 "$

Data da defesa: 28/05/2015.

Comissão Julgadora:

Resultado:

Profa. Dra. Sarah Feldman (orientadora) (Instituto de Arquitetura e Urbanismo - USP)

APNOUADO

Profa. Dra. Eulalia Portela Negrelos

(Instituto de Arquitetura e Urbanismo - USP)

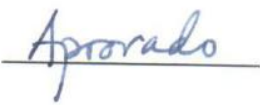

Profa. Dra. Maria Encarnação Beltrão Spósito (Universidade Estadual Paulista - UNESP)

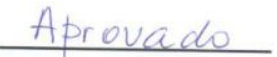

Presidente e Coordenador do Programa de Pós-Graduação em Arquitetura Urbanismo: Prof. Dr. Márcio Minto Fabrício 


\title{
UNIVERSIDADE DE SÃO PAULO
}

Escola de Engenharia de São Carlos

Programa de Pós Graduação em Arquitetura e Urbanismo

\section{INDUSTRIALIZAÇÃO E URBANIZAÇÃO EM SÃO CARLOS NAS DÉCADAS DE 1930 A 1960}

\author{
Jardel Pontes Feitosa
}

Dissertação apresentada ao Programa de Pós-Graduação em Arquitetura e Urbanismo da Escola de Engenharia de São Carlos da Universidade de São Paulo, sob orientação da Profa. Dra. Sarah Feldman, como parte dos requisitos para obtenção do título de Mestre em Teoria e História da Arquitetura e Urbanismo. 
AUTORIZO A REPRODUÇAO TOTAL OU PARCIAL DESTE TRABALHO, POR QUALQUER MEIO CONVENCIONAL OU ELETRÔNICO, PARA FINS DE ESTUDO E PESQUISA, DESDE QUE CITADA A FONTE.

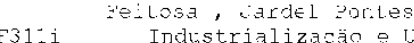

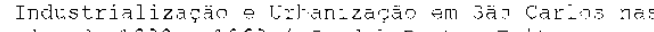
lécadas de $193 \hat{0}$ a 1960 ; Jande- Pontes Iétosa. or-ertadorá Saralı geldman. Săc Carlos, $23: 5$.

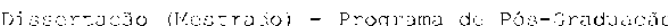

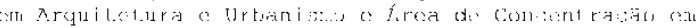

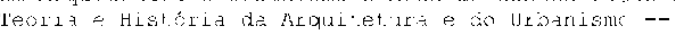
lnetrtuti de Arquitetura - Urasiem da Jri"ersidade de Să० Palllo, 2015

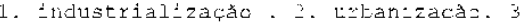
deservelvimento ecocomics. 4. Eengrafia urbana. I. Títu-o. 
Aos geógrafos, urbanistas, historiadores e economistas: que este trabalho possa contribuir para conhecer São Carlos e aprimorar os conhecimentos nessa importante seara. 


\section{AGRADECIMENTOS}

Agradeço à CAPES por conceder 24 meses de bolsa.

Algumas pessoas merecem meu reconhecimento. Primeiramente, agradeço a Sarah Feldman, com quem aprendi muito sobre urbanismo e sobre a vida no meio acadêmico. Orientação sempre presente, com intervenções precisas e esclarecedoras.

Agradeço as professoras Maria Encarnação Beltrão Spósito e Eulália Portela Negrelos, por participarem da banca de qualificação, contribuindo decisivamente para melhorar a qualidade do trabalho. A leitura para banca final foi minuciosa e as críticas muito bem colocadas. Um privilégio conviver com três mulheres dedicadas, competentes e inteligentes.

Agradeço aos esforços de pesquisadores que foram fundamentais para nosso estudo: Ary Neves, Oswaldo Truzzi, Jonas Abreu, Renata Lima, Regina Devescovi, entre outros.

Agradeço aos meus professores de graduação e pós-graduação. Aos funcionários públicos do Instituto de Arquitetura e Urbanismo, da Câmara Municipal e da Fundação Pró-Memória, que sempre me atenderam quando precisei. Aos empresários Italinho Cardinali, Fernando Pereira Lopes, Irineu Massari e Mario Maffei, que me receberam muitíssimo bem e contribuíram com a pesquisa. Ao barbeiro Sr. Francisco Rossi, pelas valiosas dicas sobre a localização dos estabelecimentos antigos.

Duas pessoas especiais me acompanharam nessa jornada de estudos. Meu amigo Renato Lima, que conheci durante o mestrado e vou guardar sua amizade para o resto da vida, e minha namorada Ana Carolina, que abriu uma porta muito especial para mim, colorindo e perfumando os meus dias. 
"o espaço total, que escapa à nossa apreensão empírica e vem ao nosso espírito sobretudo como conceito, é que constitui o real, enquanto que as frações do espaço, que nos parecem tanto mais concretas quanto menores, é que constituem o abstrato, na medida em que o seu valor sistêmico não está na coisa tal como a vemos, mas no valor relativo dentro de um sistema mais amplo" (SANTOS, 1992:18). 


\section{RESUMO}

Essa dissertação tem por objetivo analisar as relações entre os processos de industrialização e de urbanização no município de São Carlos, localizado no CentroOeste paulista, entre as décadas de 1930 e 1960. O recorte temporal enquadra-se na etapa de desenvolvimento industrial brasileiro marcado pela concentração da produção no estado de São Paulo. Nesse período, o nexo econômico da industrialização se impõe à dinâmica urbana. As relações entre industrialização e urbanização da área urbana em São Carlos, no período em tela, foram estudadas em três dimensões. Em relação aos processos territoriais, destacamos a distribuição das indústrias, dos loteamentos e dos grupos sociais no território, procurando a lógica por trás dos arranjos, sobretudo, a influência dos sistemas de transportes sobre conformação espacial. Em relação à atuação do poder público no controle e/ou incentivo à instalação de indústrias, mostramos as mudanças da composição política relacionada ao desenvolvimento econômico e, por conseqüência, à ascensão das classes sociais ligadas ao processo de industrialização. Essas mudanças políticas colocaram na agenda do poder público, do âmbito nacional até o local, o desenvolvimento industrial e urbano. A terceira dimensão, analisamos a participação dos industriais no processo de expansão urbana, ou seja, como empresários ligados ao processo de industrialização promoveram a expansão urbana. Os objetivos acima expostos foram atingidos através de pesquisa bibliográfica, levantamento de dados estatísticos, dados secundários, bases cartográficas, entrevistas com empresários, pesquisa em jornais e pesquisa documental nos arquivos da Prefeitura de São Carlos, em especial na Fundação Pró-Memória de São Carlos. 


\begin{abstract}
This dissertation aims to examine the relationships between the processes of industrialization and urbanization in São Carlos, located in the Central West of the state of São Paulo, between the 1930s and the 1960s. The period in focus refers to Brazilian stage of industrial development, which is characterized by the concentrate of production in the state of São Paulo. In this period, the nexus of industrialization is imposed on urban dynamics. The relations between industrialization and urbanization in São Carlos, were be studied in three dimensions. In relation to territorial processes, highlight the distribution of industries, allotments and social groups in the territory, looking for the rationale behind the arrangements, especially the influence of transport systems on spatial conformation. In relation to the government's role in controlling and/or encourage the installation of industries, present changes of the political composition related to economic development and, consequently, the rise of social classes linked to industrialization. These political changes put in the government's agenda, at the national to the local scope, industrial and urban development. The third dimension, we analyze the participation of industrial entrepreneurs in the urban expansion process, that is, how businessmen linked to industrialization promoted urban sprawl. The objectives above were achieved through a bibliographical review, statistical and secondary data survey, cartographic databases, interviews with entrepreneurs and research in papers and documental research in the archives of the city of São Carlos, in particular at Fundação Pró-Memória de São Carlos.
\end{abstract}




\section{SUMÁRIO}

INTRODUÇÃO.

\section{CAPÍTULO O1 - O “FÁCIES BUROCRÁTICO” DA CIDADE E A TRANSIÇÃO}

\section{PARA O CAPITALISMO INDUSTRIAL}

1.1 - Desenvolvimento do Complexo Cafeeiro do Oeste Paulista...... .23

1.2 - O complexo cafeeiro e a formação do mercado interno. .34

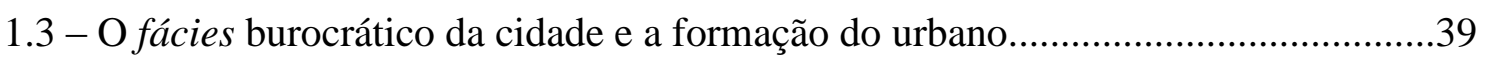

1.4 - Estado moderno e transição para o capitalismo industrial.

\section{CAPÍTULO 02 - INDUSTRIALIZAÇÃO E TRANSFORMAÇÃO SOCIOESPACIAL EM SÃO CARLOS NAS DÉCADAS DE 1930 A 1960}

2.1- Expansão urbana e desenvolvimento econômico em São Carlos até 1929 .57

2.2 - Crescimento industrial em São Carlos: décadas de 1930 e 1940 71

2.3 - A primeira fase da industrialização pesada em São Carlos: décadas de 1950 e 1960. .80

2.4- As indústrias e o sistema de transporte sobre trilhos.

2.5 - As moradias próximas ao local de trabalho e concentração das atividades econômicas .93

2.6 - O sistema rodoviário e a ruptura da proximidade entre moradia e trabalho. 103

2.7 - A segregação socioespacial em São Carlos nas décadas de 1950 e 1960. 


\section{CAPÍtulo 03 - AgENTES PÚBLICOS E PRIVADOS NOS PROCESSOS DE INDUSTRIALIZAÇÃO E URBANIZAÇÃO}

3.1 - Atuação do Estado no processo de industrialização nas décadas de 1930 a

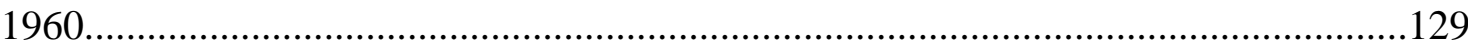

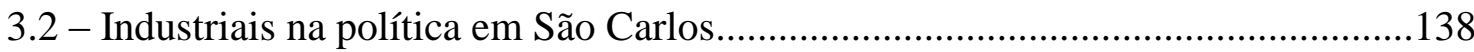

3.3 - Incentivos às indústrias e regulação urbanística em São Carlos..........................148

3.4 - Atuação dos industriais nos negócios imobiliários................................................158

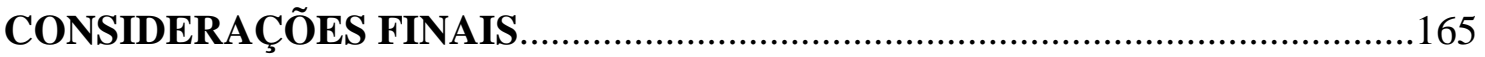

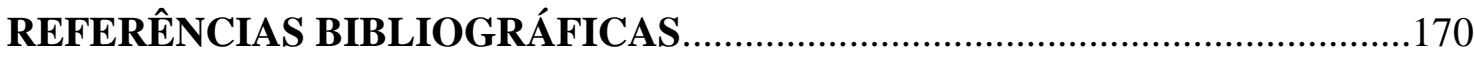

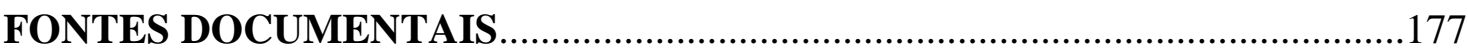

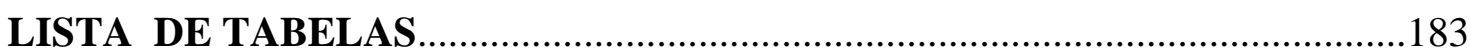

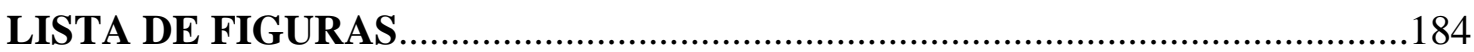

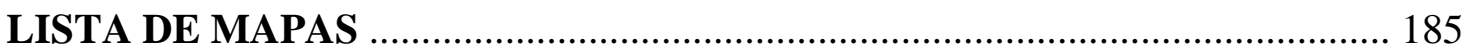

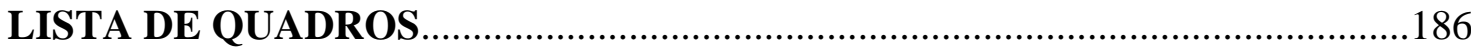




\section{INTRODUÇÃO}

O estudo que realizamos estabelece a relação entre os processos de industrialização e urbanização no município de São Carlos nas décadas de 1930 a 1960. Analisamos essa relação em três dimensões: a que trata dos processos econômicos e territoriais (indústrias, comércio, infraestrutura, loteamentos, grupos sociais); outra que tange à atuação do poder público nos processos de industrialização e urbanização; e a terceira que procura relacionar a inserção de empresários ligados ao processo de industrialização, no ramo imobiliário e na política

As peculiaridades da formação industrial paulista e sua relação com o processo de urbanização definiram o recorte temporal adotado. Os principais estudos sobre o processo de industrialização em que nos apoiamos, como Baer (1975), Cano (1983), Dean (1991), Furtado (1968), Negri (1996), Rangel (1985) e Rattner (1972), apontam que até o final da década de 1960, a industrialização paulista passou por três fases: a industrialização subordinada ao café - até 1929; a industrialização restringida - de 1930 até 1955; e a primeira fase da industrialização pesada - 1956 até 1967. Negri (1996) e Rattner (1972) estudaram o processo de industrialização paulista com ênfase na concentração e desconcentração espacial da indústria. Conforme apontam, esses três cortes temporais formam o período de "concentração industrial", i.e, quando as taxas de crescimento industrial eram maiores na capital e região metropolitana. A partir de 1967, a industrialização no interior do estado adquire maior taxa de crescimento.

Até 1929, a indústria crescia de forma dependente da renda dos produtos de agroexportação, principalmente o café. O colapso de 1929 e a Revolução de 1930 foram acontecimentos marcantes que desencadearam o processo de crescimento econômico por substituição de importações e romperam com o modelo agroexportador. Entre 1930 e 1955, o crescimento industrial teve como causa primária as tensões estruturais motivadas pelo declínio da capacidade de importar e pela atuação do Estado. A partir de meados da década de 1950, as indústrias estrangeiras se instalam no estado de São Paulo, introduzindo, principalmente, as indústrias de base e de bens de capital e integrando a produção e o mercado internos.

Essas etapas do processo de industrialização repercutiram na urbanização em São Carlos. Até 1929, a cidade de São Carlos funcionava como sede comercial e administrativa subordinada ao capital comercial estrangeiro. Nas décadas de 1940 e 1950, se intensificou o crescimento industrial e o espaço urbano se tornou o local dessa 
produção, com instalação de indústrias que atraíram trabalhadores e desenvolveram o comércio e os serviços. Nessas décadas, as indústrias se concentraram próximas à estação ferroviária e os trabalhadores estabeleciam suas residências próximas ao local de trabalho. Nas décadas de 1950 e 1960, sob influência da industrialização pesada, da ampliação do sistema rodoviário e da introdução dos ônibus urbanos, ocorreu uma mudança na localização das indústrias e dos loteamentos, seguindo os eixos rodoviários. Essas mudanças também foram acompanhadas da alteração nos padrões urbanísticos e da segregação socioespacial. No final da década de 1950, teve início um processo de estruturação de órgãos de planejamento urbano em São Carlos. Em 1966, foi aprovada a lei que criou a zona industrial no município, marcando a atuação técnica do poder público municipal em relação à instalação e localização das indústrias.

Além da concentração industrial na capital e região metropolitana até a década de 1960, o marco analítico se encerra no final dessa década, pois a partir da década de 1970 o governo federal adota uma política de descentralização industrial do estado de São Paulo para o restante do país, dando início ao processo de desconcentração em escala nacional (NEGRI, 1996). Esse fato introduziria um novo elemento a ser considerado, ampliando a questão. Tendo em vista a proposta de aprofundamento da pesquisa sobre a relação entre industrialização e urbanização, encerramos a análise na década de 1960.

Assim, de acordo com essas considerações sobre os processos de industrialização e urbanização, definimos como período para nossa pesquisa as décadas de 1930 a 1960.

Anterior a esse período, analisamos no estado de São Paulo e em São Carlos, os fatores que permitiram a transição para o capitalismo industrial. Mostramos a relação de dependência da economia e do espaço urbano ao capital mercantil estrangeiro até o final da década de 1920: a imposição do "velho" Imperialismo europeu e norte americano. Para isso, nos apoiamos, nos estudos de Dean (1977), Mello (1982), Rossini (1988), Lorenzo (1998) e, principalmente, Monbeig (1998), nos quais os autores analisam, no Oeste Paulista, a expansão da cultura cafeeira, o desenvolvimento dos transportes ferroviário e rodoviário, a implantação de usinas de energia elétrica e o crescimento populacional por imigração. A introdução desses elementos permitiu o desenvolvimento industrial no estado de São Paulo à frente do restante do país.

Sobre a relação entre industrialização e urbanização a partir de 1930, alguns estudos foram fundamentais para nossa abordagem. O livro de Aroldo de Azevedo (1958) 'A cidade de São Paulo: estudos de geografia urbana', com a contribuição de diversos autores, tornou-se referência para os estudos de geografia urbana. No que se 
refere à nossa pesquisa, destacamos as análises sobre a localização das indústrias, as infraestruturas, a concentração ou dispersão de comércio e serviços, a distribuição dos grupos sociais e a produção dos loteamentos. O estudo de Mattos (1958) 'O parque industrial paulistano' é paradigmático no que se refere ao processo de industrialização. O autor analisa a importância do café para a indústria, a contribuição do imigrante, a localização geográfica e as políticas da República Velha. Em seguida, desenvolve a análise sobre a distribuição das indústrias no território, elaborando mapas por ramos de fabricação e descrevendo o processo de instalação desses ramos; estabelece também relações com as conjunturas nacionais e internacionais, analisa o papel das rodovias como eixos de ligações aos mercados e a paisagem industrial da capital. Müller (1958) estuda as transformações urbanas na área central de São Paulo relacionada às atividades econômicas e faz o mapeamento das funções que as áreas urbanas desempenhavam no ano de 1952, a saber, a função comercial, a função industrial, as profissões liberais e a função bancária. Penteado e Petrone (1958) analisam o desenvolvimento de São Caetano do Sul e Osasco e as bases físicas sobre a qual se desenvolveu a indústria, bem como a distribuição das indústrias sobre o território. Petrone (1958), ao analisar a cidade de São Paulo no final do século XIX, mostra que as principais áreas industriais acompanharam a via férrea e que essa função industrial ocasionou a expansão urbana de 1925 a 1950, acompanhando as vias férreas, nas direções Norte, Oeste, Leste e Sudeste. Para o Sul, as linhas de bondes, as estradas de rodagem e a construção das represas da Light concorreram para que numerosos bairros residenciais de classe média e algumas indústrias viessem a se instalar naquele local.

O clássico estudo de Paul Singer (1968) 'Desenvolvimento econômico e evolução urbana' analisa o processo de desenvolvimento econômico pela ótica da evolução urbana, pois esta abordagem, segundo o autor, permite enfocar com maior acuidade os efeitos integrativos sobre a economia do país. Assim, Singer estuda a evolução de cinco cidades (São Paulo, Blumenau, Porto Alegre, Belo Horizonte e Recife) com o objetivo de captar o processo de desenvolvimento mediante a multiplicidade dos seus efeitos em diferentes partes do país. No caso de São Paulo, Singer mostra que o crescimento vertiginoso da capital é fruto de sua industrialização e da tendência "natural" do capital industrial à concentração econômica e espacial. Aponta que São Paulo superou a indústria do Rio de Janeiro devido, principalmente, à oferta de infraestruturas de transporte e de energia e por sua posição geográfica privilegiada em relação aos mercados internos emergentes. 
Ressaltamos ainda dois estudos sobre cidades médias paulistas, mas ambos se concentram no período posterior a década de 1960. A cidade de Marília foi estudada por Mourão (1994), que analisou a relação entre industrialização e urbanização. Ao tratar da organização do espaço urbano-industrial, mostra que a indústria atua como um importante elemento centralizador das atividades urbanas e que, internamente, as indústrias se territorializam em três áreas principais: no centro; no Distrito Industrial, situado na zona leste da cidade; e ao longo das rodovias Marília-Bauru e Transbrasiliana, na direção de Ourinhos. Gomes (2007) estudou as cidades de Araçatuba, Birigui, Presidente Prudente, Marília e São José do Rio Preto, e mostra que a gênese do capital da indústria de origem familiar implicou na criação de indústrias articuladas com a agropecuária, até passar por um processo de reestruturação na década de 1990, provocando o surgimento de novos ramos industriais e mudanças nas condições de trabalho.

A cidade de São Carlos possui estudos que abordam seu desenvolvimento econômico e urbano e que utilizamos como fontes bibliográficas. Lorenzo (1979) analisa o processo de industrialização na região Araraquara-São Carlos e mostra os aspectos que influenciaram no fato da cidade de Araraquara ter se desenvolvido principalmente nos setores agroindustriais e em São Carlos ter predominado as indústrias metalúrgicas, têxteis, de material elétrico e de mobiliário. O estudo de Devescovi (1987) elucida aspectos importantes do processo de urbanização em São Carlos. A autora estuda os processos de urbanização e acumulação de capital desde a fundação de São Carlos até a década de 1970. Ainda aponta os efeitos da cafeicultura para a indústria e para a segregação socioespacial quando, a partir da década de 1950, começaram a se formar loteamentos precariamente implantados; entretanto, não se preocupa em examinar os agentes envolvidos na produção do espaço urbano.

O estudo de Truzzi (2000) se tornou uma referência sobre o desenvolvimento da cafeicultura e da industrialização em São Carlos até 1950. O autor se concentra sobre a produção cafeeira e industrial e as principais realizações dos cafeicultores e das classes populares (posseiros, escravos e imigrantes), mas não analisa o processo de urbanização. Abreu (2000) estuda a relação entre política, economia e urbanização entre as décadas de 1880 e 1950. Sua principal contribuição consiste em mostrar a constituição dos agentes do poder público e do mercado imobiliário e o processo de implantação de alguns loteamentos. A dissertação de Lima (2007) também analisa a produção de loteamentos, com ênfase na atuação do setor de urbanismo e sobre os 
instrumentos utilizados no controle da expansão urbana. Grimberg (2009) estuda a importância do pequeno capital industrial nas três primeiras décadas do século $\mathrm{XX}$ e mostra que esse pequeno capital foi o principal responsável pelo crescimento industrial.

A pesquisa que realizamos se apoia nestes estudos e em inúmeras fontes documentais sobre os processos de industrialização e urbanização em São Carlos até a década de 1960. Em nosso trabalho, estabelecemos a relação dos dois processos em seus aspectos territoriais e de atuação dos agentes públicos e privados. Em outras palavras, analisamos como as indústrias se desenvolvem; como se distribuem as atividades econômicas e os grupos sociais no território; como se dá a relação entre local de trabalho e local de moradia; como atuam o poder público e os empresários industriais nos processos de industrialização e urbanização e a relação entre estes agentes.

Alguns conceitos desenvolvidos por um conjunto de estudiosos serviram para o entendimento da realidade que analisamos. A partir de Ignácio Rangel (1981, 1985), que estuda a história econômica brasileira em relação aos ciclos longos da economia mundial, apreendemos a lógica macroeconômica em que estão inseridas as etapas do desenvolvimento econômico no estado de São Paulo e em São Carlos.

O conceito de "complexo econômico" designa o conjunto de atividades econômicas sobre o qual atua certo número de variáveis, independentes ou não ao conjunto, capazes de desencadear um processo dinâmico de acumulação ao próprio sistema. Partindo desse conceito, em sua obra 'Raízes da Concentração Industrial em São Paulo', Wilson Cano (1983) estudou as lavouras cafeeiras que se formaram no estado de São Paulo. A produção de café, sendo a atividade econômica principal, em conjunto com as atividades econômicas acessórias, que se desenvolvem com objetivo de aumentar a produção e a renda do setor cafeeiro, foi denominada de "complexo econômico cafeeiro". A segunda metade do século XIX foi o período em que os complexos cafeeiros se expandiram em direção ao oeste do estado de São Paulo.

Durante a etapa de expansão do complexo cafeeiro, a economia e a cidade cresciam em função da renda desse setor. Como mostra Oliveira (1982) em 'O Estado e o Urbano no Brasil', a cidade possuía, até então, o caráter de fácies burocrático, ou seja, de entreposto administrativo e comercial entre a economia colonial e a metropolitana. Nessa mesma etapa, Singer (1968) analisa o processo de formação do mercado interno, quando a economia possuía principalmente os setores de exportação e de subsistência. O setor de mercado, que produz fundamentalmente para o mercado interno, crescia ou diminuía em função do setor exportador, as expensas do setor de subsistência. Singer 
mostra que ocorre uma ruptura estrutural com esse modelo típico de economias coloniais quando a produção para o mercado cresce em função do mercado interno. Em harmonia com esse pensamento, Santos (1982), no livro 'Espaço e Sociedade' aponta que a formação do urbano se dá quando as atividades produtivas são voltadas para o mercado interno e ocorre especialização do espaço, no sentido de que a produção para o mercado induz uma divisão social do trabalho. Assim, procuramos caracterizar em São Carlos essa ruptura com o modelo econômico e urbano típico das formações coloniais dependentes. Essa "dependência" é um conceito fundamental para a compreensão de nosso estudo. Conforme Cardoso e Faletto (1981:27) na obra 'Dependência e Desenvolvimento na América Latina',

"a noção de dependência alude diretamente às condições de existência

e funcionamento do sistema econômico e do sistema político, mostrando a vinculação entre ambos. A noção de subdesenvolvimento passa a caracterizar o grau ou o estado de diferenciação do sistema produtivo [...], sem acentuar as pautas de controle de decisões de produção e consumo."

Assim, analisamos as implicações econômicas e políticas da formação do mercado interno e mostramos como São Carlos se insere nesse contexto.

Após 1930, desenvolvemos a pesquisa abordando o tema da industrialização de forma ampla, conforme aponta Santos (2002) em 'A Urbanização Brasileira', ou seja, em suas repercussões econômicas e espaciais; não apenas como criação de atividades industriais nos lugares, mas como processo social complexo que inclui a formação de um mercado nacional, expansão do setor terciário e do sistema de transporte. Vale lembrar que, na 'Crítica à Razão Dualista', Oliveira (1987) ressalta que esse conceito sobre o processo de industrialização entendido de forma restrita à produção, induz à interpretação errônea de que a urbanização cresce muito acima da industrialização, enquanto que, na realidade, o processo de industrialização assume a forma da urbanização.

As páginas que se seguem, não revelam todos os meandros que percorremos e as mudanças de caminho, pois grande parte da pesquisa documental e bibliográfica não foi redigida, muito embora tenham contribuído decisivamente para o resultado final. Assim, cremos que, ao final, não apresentamos apenas conclusões sobre um objeto de estudo, 
mas uma metodologia de estudo construída pela necessidade e pelo descobrimento de fontes documentais.

Consultamos os almanaques de São Carlos no período de 1894 até 1928, de onde extraímos informações valiosas sobre a implantação de infraestruturas urbanas e sobre o crescimento do setor industrial, comercial e de serviços. Pelos Códigos de Posturas analisamos a atuação do poder público no controle sobre a expansão urbana e indústrias.

Sobre indústrias após 1930, consultamos na Fundação Pró-Memória de São Carlos, o Livro de Impostos sobre Indústrias e Profissões da Prefeitura para os anos de: 1930; 1934; 1938; 1942; 1946; 1948. Após essa data, os livros não foram encontrados. Coletamos os dados sobre nome, endereço, produtos fabricados/comercializados e impostos dos estabelecimentos industriais e comerciais. Como não havia organização desses dados, separamos os estabelecimentos por ramos de fabricação e comercialização.

Outros documentos importantes sobre indústrias foram o Catálogo das Indústrias do Estado de São Paulo (disponível na biblioteca da Faculdade de Economia e Administração de Ribeirão Preto e no site do SEADE), o Cadastro Industrial de 1965 (disponível na biblioteca da Faculdade de Engenharia de São Carlos) e o Guia de Informações de São Carlos de 1969 (disponível na Fundação Pró-Memória de São Carlos). A partir da análise e sistematização dos dados presentes nesses documentos, foi possível analisar o desenvolvimento da indústria em seus aspectos econômicos e territoriais.

Para a elaboração dos mapas que representam a expansão urbana e a localização das indústrias, do comércio e bancos, utilizamos bases cartográficas de 1930, 1949 e 1976. As duas primeiras disponíveis no Arquivo Público do Estado de São Paulo e a última na Fundação Pró-Memória de São Carlos. Por se tratar de documentos originais e desgastados pelo tempo, tiveram de ser restaurados digitalmente. Como os endereços anteriores à década de 1950 não correspondem aos atuais, para localizá-los, foi necessário identificar os prédios ainda existentes e através de entrevistas encontrar os demais endereços.

As informações sobre os loteamentos foram consultadas nas dissertações de Abreu (2000) e Lima (2007). Através do cruzamento dos nomes dos proprietários das indústrias e dos proprietários de loteamentos, identificamos os empresários industriais que se inseriram no ramo imobiliário. 
Pesquisamos no arquivo da Câmara Municipal de São Carlos os nomes e as profissões dos políticos de São Carlos, para caracterizar as mudanças na representação do poder público. Contextualizamos com as principais realizações do poder público, sobretudo no tocante aos incentivos e/ou regulação sobre o processo de industrialização.

A legislação sobre São Carlos até a década de 1930 foi consultada nas Atas da Câmara Municipal de São Carlos, disponíveis no acervo da Fundação Pró-Memória de São Carlos. A partir da década de 1940, consultamos a legislação municipal na internet, no site da Câmara Municipal de São Carlos. A legislação Estadual e Federal foi consultada a internet, nos sites da Câmara Legislativa Estadual e Federal.

Outros arquivos com informações sobre indústrias e estatísticas de população em São Carlos foram consultados no acervo digital do SEADE e no IBGE de São Carlos. Todas essas fontes e referências que apontamos estão devidamente indicadas ao longo da dissertação.

No capítulo 01, mostramos que a expansão do Complexo Cafeeiro do Oeste Paulista repercutiu na implantação de infraestruturas de transporte e de energia elétrica até a década de 1920. Mostramos ainda o aumento populacional nessa região em função da oferta de empregos nas lavouras cafeeiras. Analisamos o desenvolvimento do mercado interno no contexto de uma economia periférica, salientando seu caráter dependente (econômico e político), no sentido de que as decisões que afetam a produção ou o consumo de uma economia subdesenvolvida são tomadas em função da dinâmica e dos interesses das economias desenvolvidas. A questão da formação do mercado interno na transição para o capitalismo industrial se associa à formação do urbano. A teoria da Cidade Local de Milton Santos (1982) caracteriza a formação do urbano pela divisão social do trabalho e pela formação do mercado interno. Desse modo, relacionamos a etapa de transição para o capitalismo industrial com a formação do urbano em São Carlos. Por fim, analisamos a teoria marxista de formação do Estado Moderno e as peculiaridades do Estado e da revolução burguesa "pelo alto" que ocorreu no Brasil. Esse Estado haveria de assumir papel protagonista no processo de industrialização. Assim, mostramos também como se deu, de forma geral, o processo de industrialização no Brasil entre as décadas de 1930 e 1960.

No capítulo 02, efetuamos uma análise dos processos de industrialização e urbanização no município de São Carlos baseado principalmente em fontes documentais. O período analisado está circunscrito à etapa de concentração espacial da 
produção industrial, que pode ser dividido na industrialização restringida (1930-1955) e na primeira fase da industrialização pesada (1956-1967).

Dividimos o capítulo em três partes. Na primeira, analisamos o desenvolvimento econômico e urbano de São Carlos até 1929. A seguir, focamos nos processos econômicos e espaciais da industrialização nas décadas de 1930 a 1960. Na terceira parte, relacionamos a industrialização com a expansão urbana em dois momentos distintos: de 1930 a 1948 e de 1949 até 1969, pois nesses dois momentos ocorrem mudanças na lógica da industrialização e urbanização e na relação entre ambas. Em relação à industrialização, o primeiro momento é marcado pela produção de bens de consumo não duráveis. Por isso, nesse caso, é usual utilizar o termo "crescimento industrial" e o termo "industrialização" para o segundo momento, quando se constitui o setor de bens de produção e bens de capital. Nesses dois momentos, a relação entre atividades econômicas e urbanização se altera.

No capítulo 03, analisamos a atuação dos agentes públicos e privados nos processos de urbanização e industrialização em São Carlos. Em relação ao poder público, mostramos as mudanças na composição e na forma de atuação nas esferas Federal e Municipal de São Carlos, no período posterior à Revolução de 1930 até o final da década de 1960. Na esfera Federal, centramos a análise nos incentivos para o processo de industrialização, através de fontes bibliográficas e da Legislação Federal. Em São Carlos, pesquisamos registros sobre os políticos, legislação Municipal e Estadual, jornais, bibliografias e entrevistas com empresários industriais e do ramo imobiliário, para compreender como se deu a atuação do poder público e de empresários nos processos de industrialização e urbanização em São Carlos. 
CAPÍTULO 01 - O "FÁCIES BUROCRÁTICO” DA CIDADE E A TRANSIÇÃO PARA O CAPITALISMO INDUSTRIAL 


\section{1 - Desenvolvimento do Complexo Cafeeiro do Oeste Paulista}

As primeiras lavouras cafeeiras foram introduzidas no Brasil no Vale do Paraíba, estado do Rio de Janeiro, a partir do final do século XVIII, dando início a um novo ciclo econômico na história do Brasil. No início do século XIX, o café migrou para o estado de São Paulo em busca de novas terras férteis. A "marcha do café" prosseguiu rumo ao interior do estado e, no final do século, São Paulo controlava a maior produção de café mundial. Segundo Cano (1983), com a queda da produtividade cafeeira no Vale do Paraíba por esgotamento do solo e envelhecimento da lavoura, as terras no chamado "Oeste Paulista" foram um "livre conduto" à expansão cafeeira, tanto no que se refere à sua disponibilidade quantitativa, quanto ao seu principal aspecto, que se refere às condições propícias de clima, fertilidade e topografia.

Os problemas com o transporte, decorrente das longas distâncias do porto, persistiram por curto período, solucionado pela implantação da ferrovia. O mapa abaixo mostra a localização das lavouras de café no estado de São Paulo no início do século $\mathrm{XX}$.

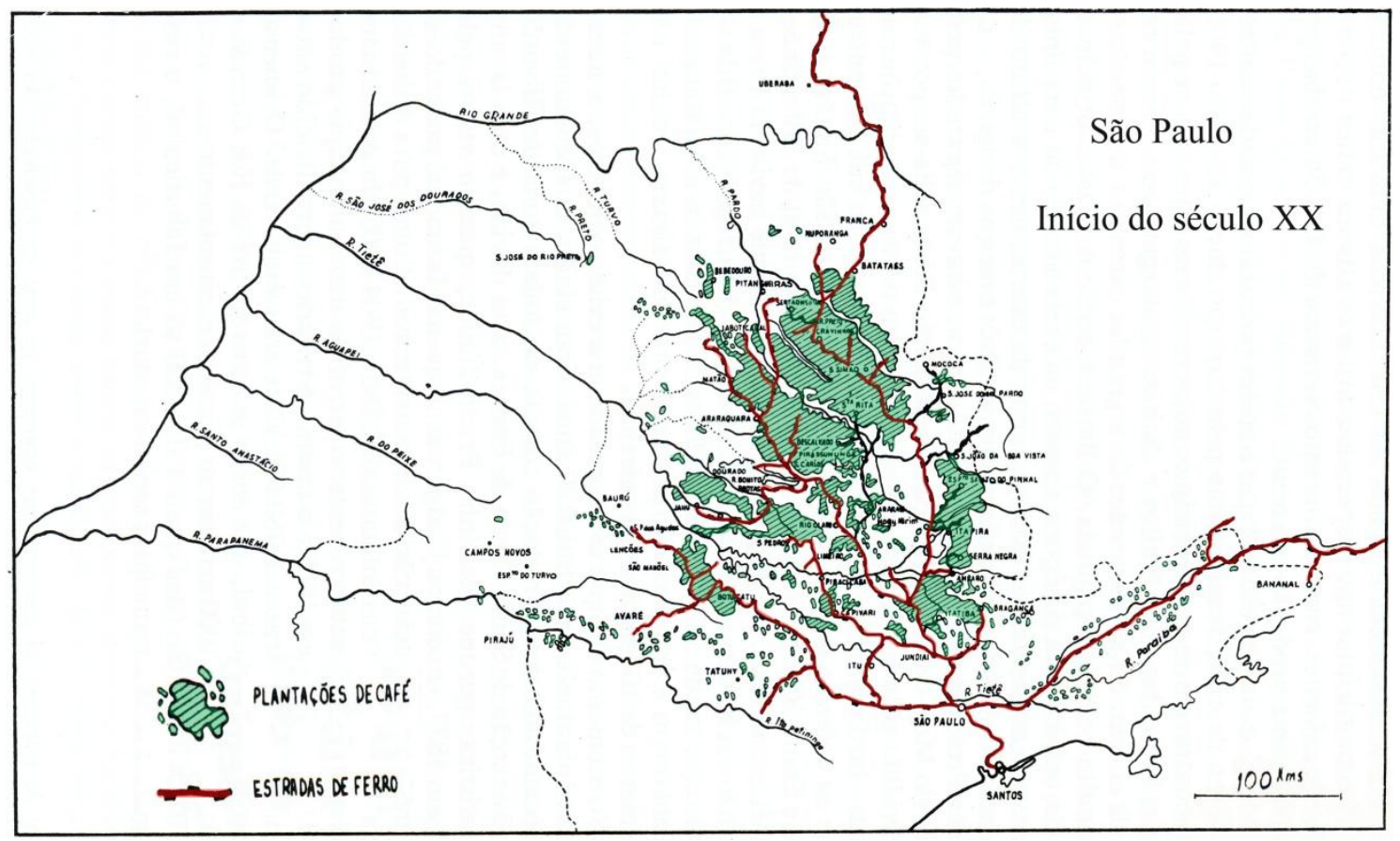

Mapa 01: Localização das lavouras cafeeiras e ferrovias no início do século XX

Fonte: Modificado pelo autor com base em: MONBEIG, 1998:169.

Mostraremos que, além da implantação das ferrovias e estradas, a expansão das lavouras cafeeiras para o Oeste Paulista induziu um aumento populacional nessa região 
e a introdução de infraestruturas de transporte e de energia. A diversificação de atividades levou ao aumento da renda interna e do fluxo de importação. Com a demanda de importação instalada, em conjunto com as dificuldades de importação devido às políticas cambiais e crises cíclicas do capital, foi reforçada a substituição de importações através de pequenas manufaturas que evoluíram para estabelecimentos mecanizados. Após a queda da produção cafeeira, na década de 1930, as pré-condições para o estabelecimento do capitalismo industrial estavam consolidadas.

Apoiados nessas considerações, ressaltamos fatores que contribuíam para a disparidade regional que caracterizou o desenvolvimento do mercado interno paulista e o tornou o centro da economia nacional. Caio Prado Jr (PRADO, 2010) salienta que a concentração da produção industrial no estado de São Paulo deve-se, em muito, aos efeitos da economia cafeeira, como a imigração, trazendo sua experiência da Europa; ao grande potencial hidráulico do estado, que possibilitou a produção de energia elétrica; e ao desenvolvimento tecnológico dos transportes e comunicações, que determinaram posição estratégica em relação ao mercado do centro-sul. Singer (1986) também aponta como explicação para o êxito da produção paulista, a disponibilidade de energia elétrica e transportes, que acabaram por determinar uma posição estratégica do estado e da capital em relação ao emergente mercado interno, possibilitado pelo sistema viário ferroviário e, posteriormente, rodoviário.

O surto das ferrovias paulistas rumo ao oeste do estado ocorreu a partir de 1860 , com a construção da Estrada de Ferro Santos-Jundiaí, realizada pela antiga companhia inglesa São Paulo Railway. A ligação com áreas mais afastadas do oeste paulista foi realizada por empresas fundadas com capital dos grandes fazendeiros de café. Quatro empresas contribuíram para desbravar o oeste: A Cia. Paulista de Estradas de Ferro, a Cia. Mogiana de Estradas de Ferro, a Cia. Ytuana de Estradas de Ferro e a Cia. Sorocabana de Estradas de Ferro (MONBEIG, 1998).

Como pode ser observado na figura 01, a Cia. Paulista de Estradas de Ferro, concluiu o trecho ligando Jundiaí a Campinas em 1872. De Campinas seguiu para Rio Claro (1876), Araras (1880) e Descalvado (1881). Também realizou a ligação, através de um ramal que partia de Rio Claro, com Analândia (1884), São Carlos (1884) e Araraquara (1885). Somente em 1912 foi realizado o prolongamento até São José do 
Rio Preto. Em 1933 chegou até Mirassol e em 1952 atingiu o ponto final em Presidente Epitácio. Em 1929 foi realizada uma derivação em Itirapina em direção a Brotas ${ }^{1}$.

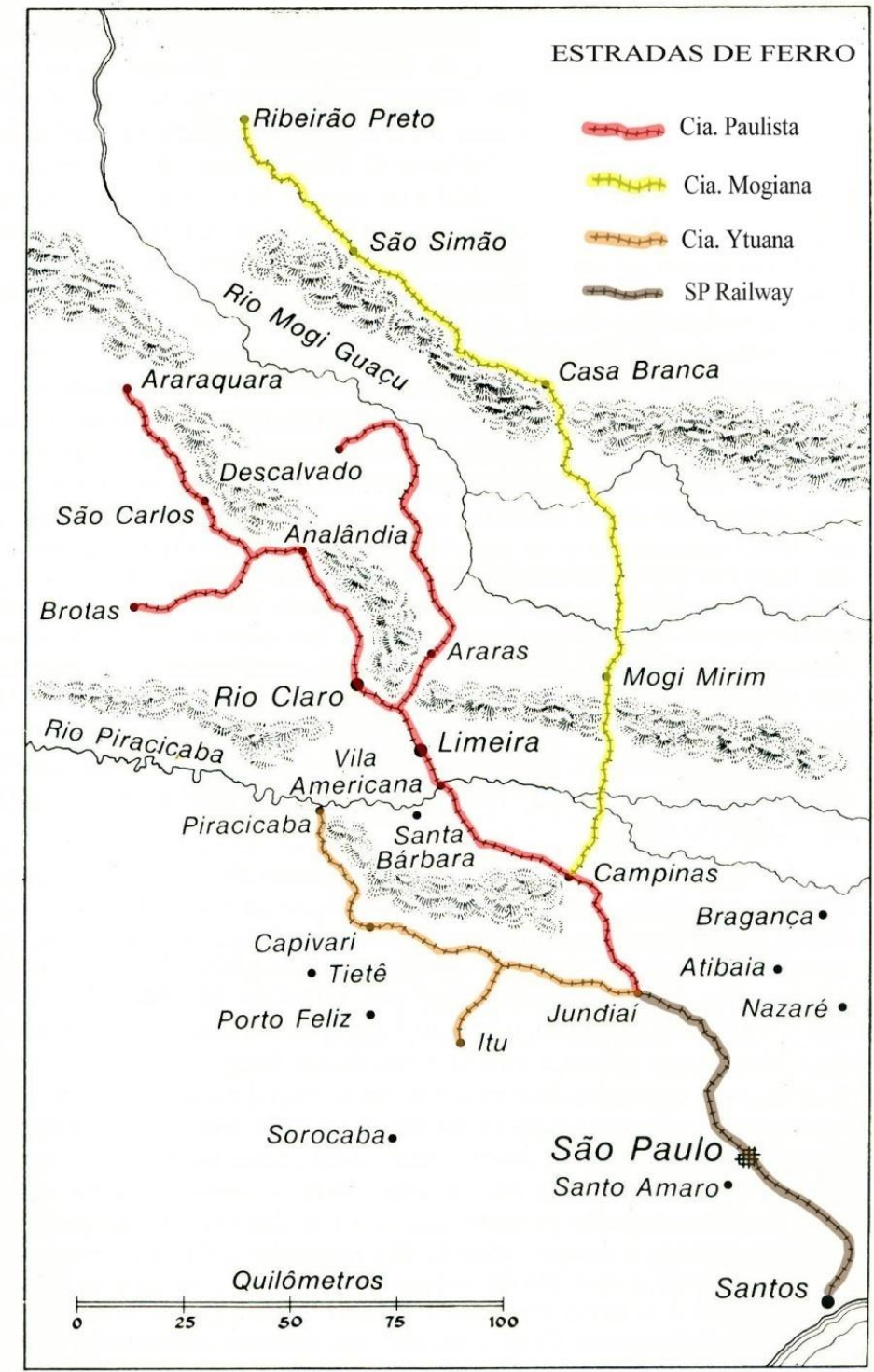

Oeste Paulista

Figura 01: Primeiras estradas de ferro do Oeste Paulista

Fonte: Modificado pelo autor com base em: DEAN, 1977:23

Segundo Monbeig (1998), o desenvolvimento das estradas de ferro obedecia aos interesses dos produtores, administradores e comerciantes de café. Assim, o plano

\footnotetext{
${ }^{1}$ Fonte: Disponível em: http://www.estacoesferroviarias.com.br (acesso em janeiro de 2015)
} 
inicial da Cia. Mogiana, que consistia em atingir Cuiabá, no coração do Brasil, acabou seguindo o percurso clássico em direção ao Triângulo Mineiro. A estrada da Cia. Mogiana começava em Campinas, seguia para Mogi-Guaçú, Casa Branca (1880), São Simão (1882), Ribeirão Preto (1883) Batatais (1886), Franca (1887) e penetrava no Triângulo Mineiro. Ficou a cargo da Cia. Ytuana uma linha menor de Jundiaí a Itu, prolongando até Piracicaba (1879) e São Miguel (1888) (SINGER, 1962). Nas duas primeiras décadas do século XX, foram construídos, pelas companhias Mogiana e Paulista, pequenos ramais ligando outros municípios produtores de café, como Dourado, Boa Esperança, Bariri, Socorro, Cravinhos, Bebedouro, Barretos, Jaboticabal, Pitangueiras e Orlândia (MONBEIG, 1998).

Inicialmente se direcionando ao sudeste do estado, mas com o prolongamento também se direcionado a oeste, até chegar à chamada "boca do sertão", a Cia. Sorocabana de Estradas de Ferro abriu o tráfego entre São Paulo e Sorocaba (1875) seguindo por Ipanema (1876), Boituva (1882), Tietê (1983), Laranjal (1886), Conchas (1887), Pirambóia (1888) até chegar em Botucatu em 1889. Em 1892, a Cia. Ytuana, à beira da falência, foi fundida pela Cia. Sorocabana. Em 1903, o governo federal assumiu a ferrovia, vendida para o governo paulista em 1905. Em 1907 foi arrendada para um grupo privado, e, mais tarde, em 1919, voltou à administração do governo até 1971, quando passou a fazer parte da FEPASA ${ }^{2}$.

Segundo Monbeig (1998), na década de 1920, a maior região produtora de café no Oeste Paulista, servida pelas Cia. Mojiana e Paulista, apresentava sinais de esgotamento. Enquanto grandes municípios produtores, como Ribeirão Preto e São Carlos, perdiam milhões de pés de café, a cultura se expandia para a região norte e, sobretudo, oeste, se aproveitando das terras virgens e propícias à produção. Essa região foi beneficiada pelo prolongamento da Estrada de Ferro Alta Sorocabana. De Botucatu partiram dois eixos: um passando por Bauru (1906) e Araçatuba (1922), dirigindo-se ao Mato Grosso até atingir o rio Paraguai; o outro, partindo de Botucatu, passava por Salto Grande (1909), Assis (1914), Presidente Prudente (1919), até atingir Presidente Epitácio (1922), à margem do rio Paraná. Assim, houve um deslocamento de produção rumo a essas regiões servidas pela Estrada de Ferro Sorocabana. Às vésperas da crise de 1929, a produção de café no oeste paulista encontrava seus pontos extremos nos arredores de

\footnotetext{
${ }^{2}$ Fonte: Disponível em: http://www.estacoesferroviarias.com.br (acesso em janeiro de 2015).
} 
Presidente Prudente, Marília, Araçatuba, Bebedouro, São José do Rio Preto e Franca (mapa 02). Além disso, a cultura do arroz, do milho e do fumo ganhavam mais importância.

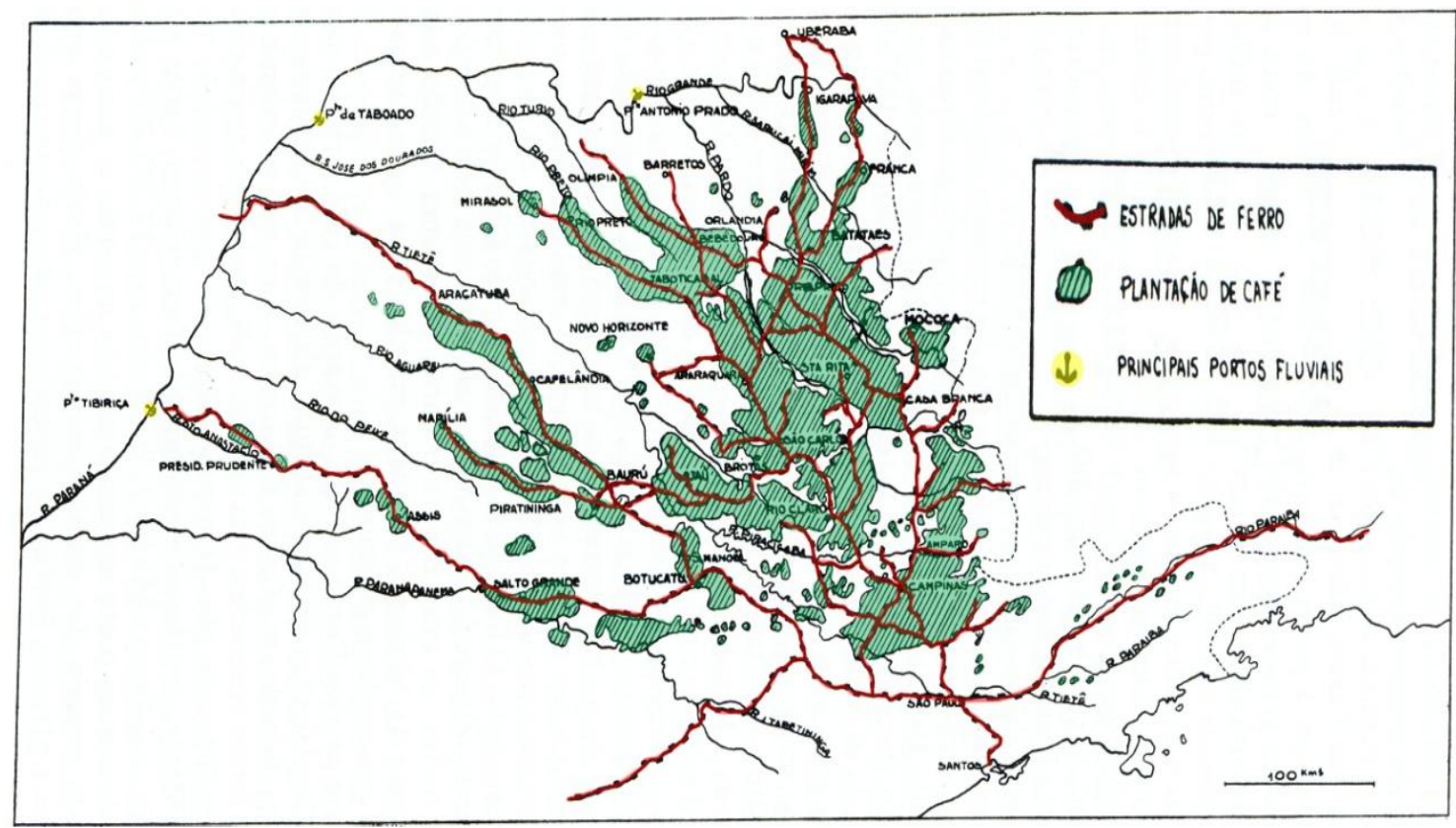

Mapa 02: Localização das lavouras cafeeiras e ferrovias às vésperas da crise de 1929

Fonte: Modificado pelo autor com base em: MONBEIG, 1998:186

A partir da década de 1920 o automóvel, ao penetrar em áreas de difícil acesso à ferrovia, começou a ganhar importância no Oeste Paulista, alargando o raio de atuação dos trilhos e permitindo maior intercâmbio entre os núcleos urbanos. Ainda de acordo com Monbeig (1998), até então a circulação dos fazendeiros de sua casa na fazenda até a estação ferroviária era realizada por meio de troles puxados a cavalo. Esse trole, que foi introduzido por imigrantes americanos vindos depois da Guerra de Secessão, começou a ceder espaço para o possante Ford, que circulava sem problemas pelos caminhos dos carros de boi. Para os fazendeiros, o Ford e o caminhão, além do transporte de pessoas, poderiam ser também poderosos instrumentos no transporte de cargas, como arroz, milho, feijão, etc. Em todas as zonas pioneiras, o primeiro caminhão apareceu em 1924.

“A iniciativa de criar a rede rodoviária ficou a cargo do governo do estado, que lançou o slogan 'boas estradas para todo o ano'. Era uma 
obra de fôlego e os poderes públicos elaboraram um plano ambicioso, que visava ligar a capital do Estado à capital federal e aos Estados de Mato Grosso e Paraná. Trabalhou-se com rapidez, em detrimento dos traçados, da qualidade e da segurança. Em 1922 uma estrada carroçável já estava aberta entre São Paulo e Ribeirão Preto, então ainda considerada a capital do café. Essa estrada foi em seguida continuada em direção ao Triângulo Mineiro, acentuando assim a permanência dos antigos rumos da circulação. Foi empreendida igualmente a construção de uma estrada até Botucatu e daí até Bauru e Mato Grosso" (MONBEIG, 1998:198).

Com a introdução do automóvel, as construções das estradas surgiram como uma necessidade para que os carros e caminhões suportassem maior peso no transporte de cargas e de pessoas. Monbeig (1998) assinala que entre 1919 e 1921, o número de carros e caminhões crescia muito acima da quilometragem dos grandes eixos rodoviários construídos pelo Estado. No entanto, na franja pioneira paulista, i.e., áreas onde os homens compravam terras dos grandes fazendeiros para a realização de empreendimentos, os fazendeiros e loteadores de terras (empresas que possuíam técnicas de agrimensura) construíram novos caminhos e alargaram os antigos, cientes que as estradas eram um prolongamento dos trilhos. Os efeitos imediatos destas ações foram a valorização das áreas servidas pela vias e a divisão e venda de terras entre cinco a vinte alqueires, bem como instalação de comerciantes nas margens das estradas.

Esses pioneiros compradores de sítios, ao contrário dos fazendeiros, eram homens pobres, geralmente colonos que abriram um comércio e que, por sua vida medíocre, tiveram possibilidade de acumular algum dinheiro e adquirir uma pequena propriedade. Sem recursos pra investir em transportes, estes sitiantes só compravam uma propriedade quando a estrada rompia o isolamento. "A estrada era uma garantia contra o isolamento e uma oportunidade a mais para a pequena propriedade, o sítio" (MONBEIG, 1998:2001).

Outra infraestrutura que se consolidou no Oeste Paulista durante as primeiras décadas do século XX foi a energia elétrica. Até o ano de 1900, a produção dessa energia era muito pouco significativa. Apenas os municípios de Sorocaba, Americana, Pinhal, Rio Claro, Piracicaba, Campinas, Jaboticabal e São Carlos contavam com 
usinas, mas com baixa capacidade de produção e pouca disponibilidade para consumo urbano e industrial. A iluminação pública, quando havia, era feita por gás ou querosene. $\mathrm{Na}$ indústria, predominavam motores a vapor, de combustão interna (gás e querosene) ou hidráulica.

Foi a partir da primeira década do século que o estado de São Paulo começou a se destacar como produtor e consumidor de energia elétrica. As causas da expansão foram, principalmente, a iluminação pública e os motores elétricos nas indústrias. Em 1907, os ramos fabris que se destacavam na produção com energia elétrica eram o têxtil, o açucareiro, o cervejeiro e o de moagem de cereais, juntos consumindo $70 \%$ da energia elétrica na indústria. Contudo, o uso de eletricidade representava apenas 18,4\% de toda a potência instalada no estado (LORENZO, 1998).

A tabela abaixo mostra a evolução da produção no estado de São Paulo nas três primeiras décadas do século XX e destaca a área do Oeste Paulista. Observa-se que a produção total do estado, que era de 4.040 HP em 1900, passa para $5.745 \mathrm{HP}$ em 1910, 225.746 HP em 1920 e 398.130 HP em 1930, o que representa um aumento de 99 vezes em três décadas. Considerando apenas as usinas com mais de 1.000 HP, a produção da região do Oeste Paulista correspondia a $71 \%$ da produção total do estado em 1910, passando para 23\% em 1910, 38\% em 1920 e 27\% em 1930. Mesmo com considerável aumento da capacidade de produção de energia elétrica da capital paulista, sobretudo na primeira década do século, o Oeste Paulista cresceu acima da média da produção paulista. 
Tabela 01: Evolução da produção de energia elétrica no estado de São Paulo.

\begin{tabular}{l|c|c|c|c|c|c|c|c|c|c}
\cline { 2 - 11 } & \multicolumn{2}{c}{1900} & \multicolumn{2}{c|}{1910} & \multicolumn{2}{c}{1920} & \multicolumn{2}{c}{1930} & \multicolumn{2}{c}{1940} \\
\hline Estado de São Paulo & HP & $\%$ & HP & $\%$ & HP & $\%$ & HP & $\%$ & HP & $\%$ \\
\hline Usinas (Total) & 4.040 & 100 & 59.745 & 100 & 225.746 & 100 & 398.130 & 100 & 488.876 & 100 \\
Usinas (+ 1.000HP) & 3.600 & 89.1 & 47.325 & 79.1 & 180.321 & 79.8 & 374.532 & 94.07 & 407.262 & 83.31 \\
\hline Regiöes & - & 100 & & 100 & - & 100 & - & 100 & & 100 \\
\hline Capital & - & - & 21.500 & 45.4 & 39.440 & 21.9 & 155.276 & 41.4 & 160.739 & 39.4 \\
V. do Paraíba & - & - & 3.435 & 7.6 & 6.520 & 3.6 & 11.037 & 2.9 & 12.032 & 2.9 \\
Central & 1.050 & 29.2 & 8.300 & 17.5 & 35.330 & 19.5 & 75.411 & 20.1 & 83.530 & 20.5 \\
Mogiana & 1.250 & 34.7 & 3.500 & 7.4 & 26.933 & 14.9 & 49.311 & 13.1 & 50.250 & 12.4 \\
Paulista & 1.360 & 37.1 & 4.300 & 9.0 & 22.729 & 12.6 & 34.988 & 9.3 & 38.980 & 9.5 \\
Araraquarense & - & - & 3.200 & 6.7 & 10.728 & 5.9 & 12.500 & 3.3 & 14.780 & 3.6 \\
Noroeste & - & - & - & - & 8.000 & 4.4 & 6.300 & 1.6 & 7.300 & 2.7 \\
A. Sorocabana & - & - & 3.100 & 6.5 & 9.672 & 5.3 & 8.000 & 2.1 & 10.274 & 2.5 \\
B. Sorocabana & - & - & - & - & - & - & - & - & 2.950 & 0.7 \\
Santos e Litoral Sul & - & - & - & - & 20.970 & 11.6 & 21.710 & 5.8 & 26.157 & 6.4 \\
\hline
\end{tabular}

Fonte: Modificado pelo autor com base em: Anuário Estatístico de São Paulo, 1901 a 1940; Censos de 1920 e 1940; Coleção de Leis e Decretos, 1902 a 1919, apud LORENZO, 1998:164.

O mapa a seguir representa a distribuição territorial da capacidade de produção do estado e a localização das usinas com mais de 1.000 HP no ano de 1930. 


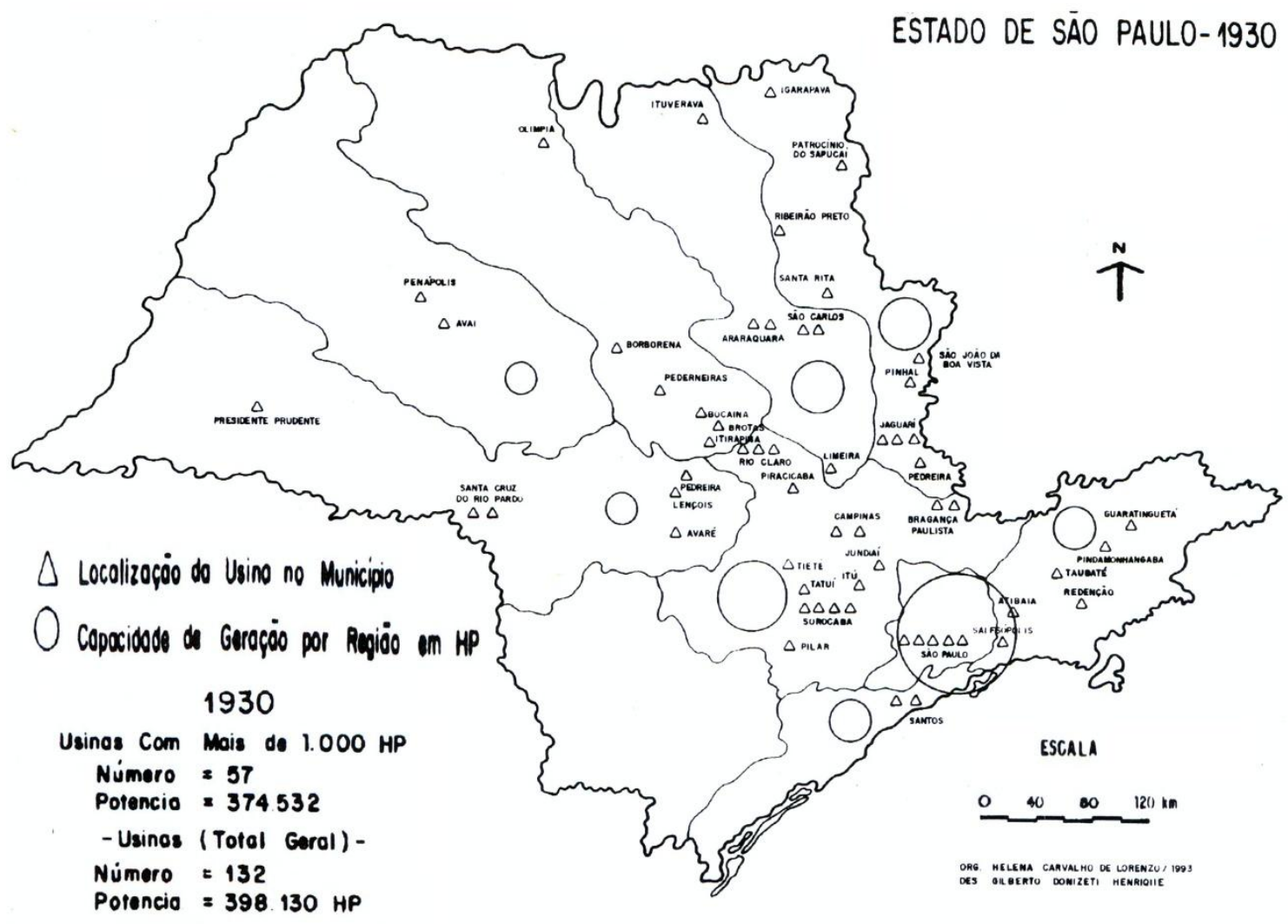

Mapa 03: Capacidade de geração de energia elétrica no estado de São Paulo e localização das usinas com mais de $1.000 \mathrm{HP}$.

Fonte: LORENZO, 1998:174

A cafeicultura foi também a principal responsável pela chegada de imigrantes no final século XX. Segundo Monbeig (1998), dos 123.069 imigrantes que chegaram no estado entre 1898 e 1902, 49.799, ou seja, 40\% se concentraram em apenas cinco municípios: Ribeirão Preto, São Simão, São Carlos, Araraquara e Jaú. O mapa abaixo mostra a distribuição dos imigrantes no estado, entre 1898 e 1902. 


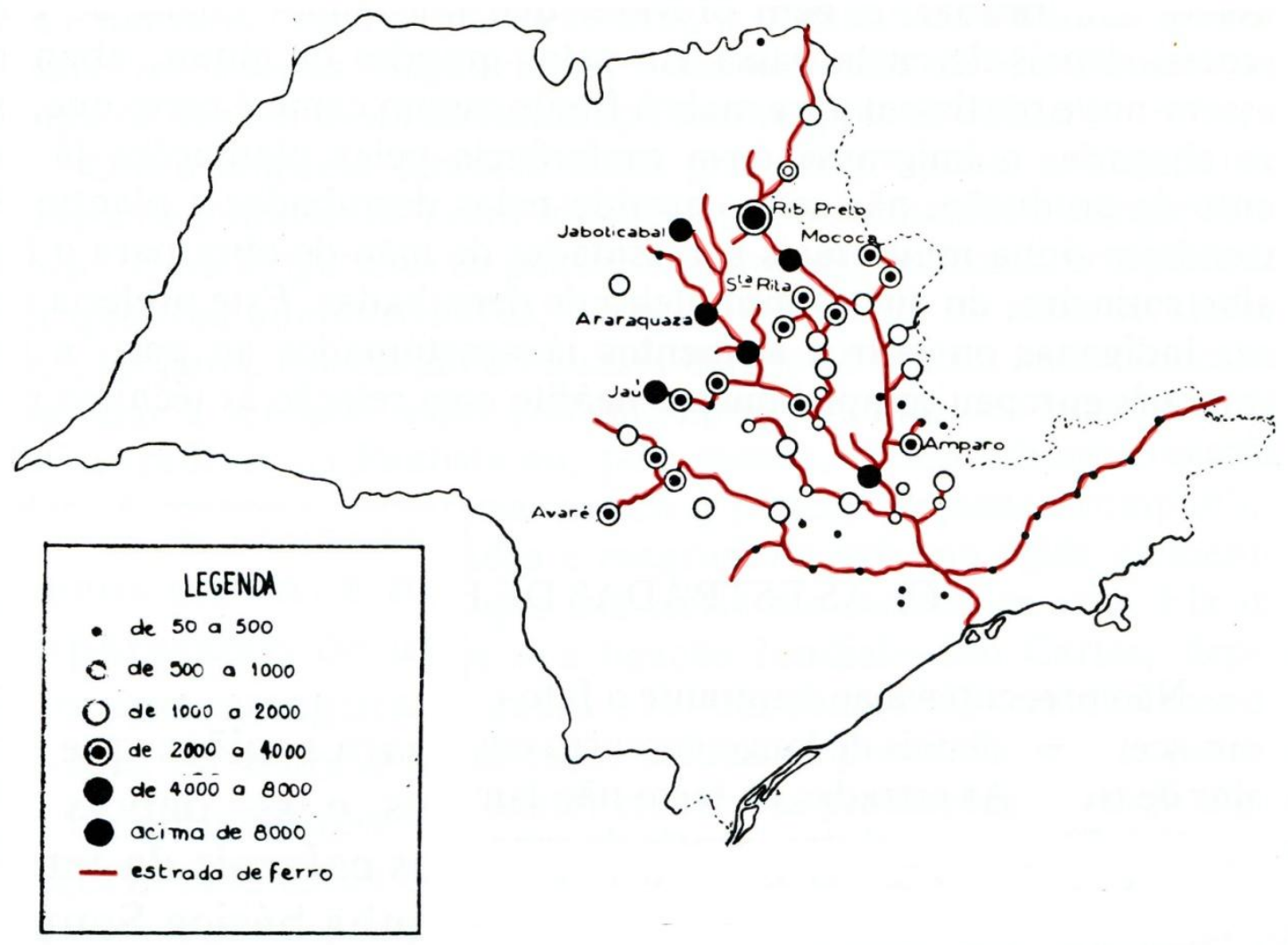

Mapa 04: Localização dos imigrantes que passaram pela Hospedaria dos Imigrantes de São Paulo no período de 1898 a 1902.

Fonte: Modificado pelo autor com base em: MONBEIG, 1998:173

Entre os anos de 1926 a 1930, a imigração estrangeira revela um novo direcionamento, seguindo a expansão da cultura cafeeira, ou seja, avançando nas regiões norte e oeste do estado, no prolongamento das estradas de ferro Mogiana e Alta Sorocabana. Entre os 233.202 imigrantes que se dirigiram para zonas rurais do estado, $84,8 \%$ foram para o planalto ocidental, com destaque para as áreas do extremo oeste, norte e noroeste do estado. Concentraram-se em alguns municípios, como Batatais, Franca, Ribeirão Preto, Rio Preto, Araçatuba, Pirajuí e Presidente Prudente (mapa 05). 


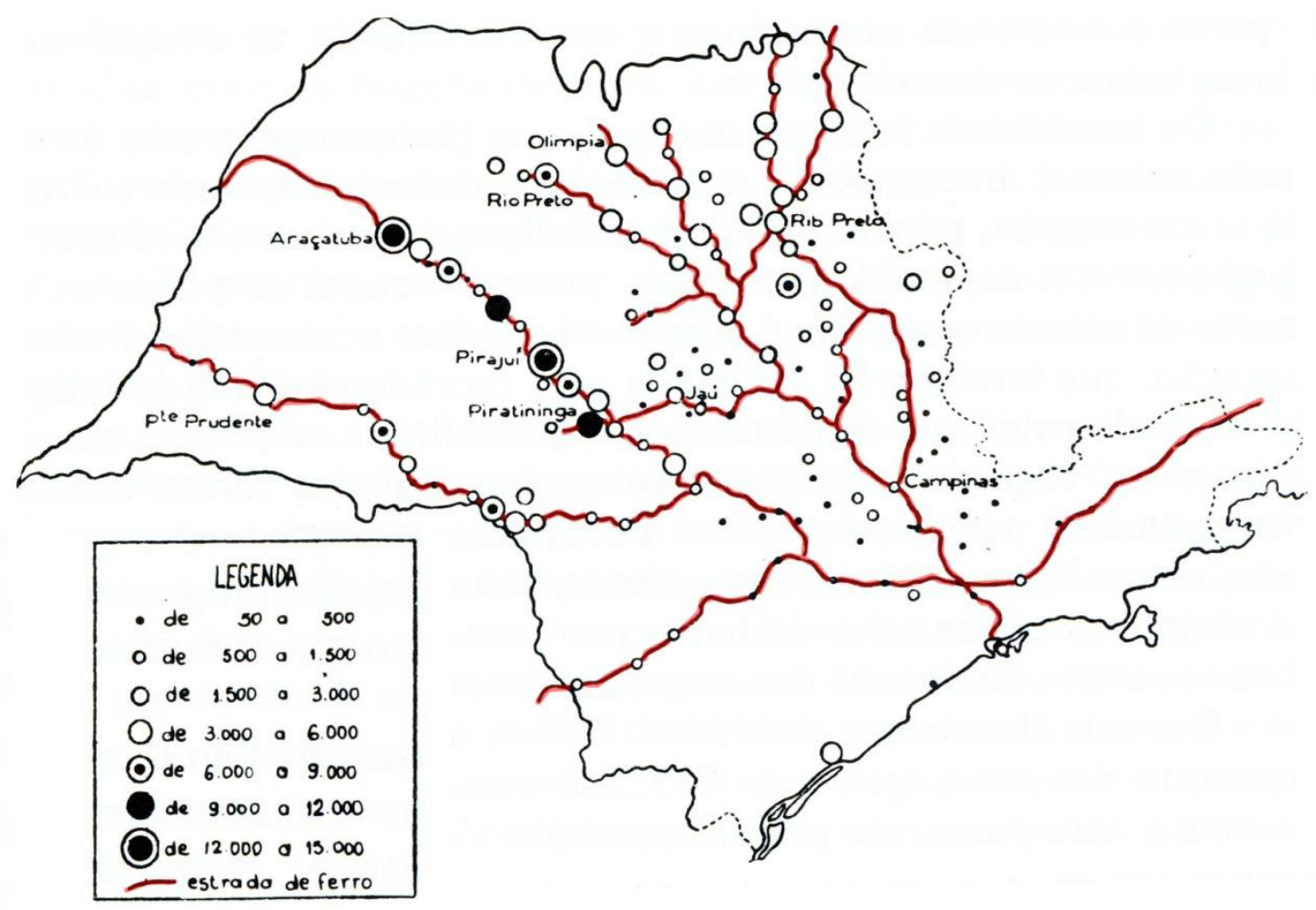

Mapa 05: Localização dos imigrantes que passaram pela Hospedaria dos Imigrantes de São Paulo no período de 1926 a 1930.

Fonte: Modificado pelo autor com base em: MONBEIG, 1998:173

Podemos afirmar que os efeitos da $2^{\mathrm{a}}$ Revolução Industrial foram experimentados no Oeste Paulista durante a década de 1920. Além da introdução do automóvel e a construção de estradas, no período, é incorporada a eletricidade e consolidado o sistema bancário. Em conjunto com a intensa imigração estrangeira, estavam dadas as condições para o desenvolvimento do processo de industrialização: ferrovias, estradas, eletricidade, bancos, mão de obra livre e indústrias simples. Couberam aos efeitos da crise mundial e da ação planejada no Estado intensificarem esse processo a partir da década de 1930. 


\section{2 - O complexo cafeeiro e a formação do mercado interno}

Em seu livro "As raízes da concentração industrial em São Paulo", Wilson Cano (1983) analisa os complexos econômicos agroexportadores e mostra que a busca por maiores patamares de acumulação na produção primária, principalmente do café, induziu a criação de um mercado interno e a implantação de infraestruturas que possibilitaram o desenvolvimento da economia industrial e o crescimento das cidades vinculadas à industrialização. Para Cano, a raiz da concentração da produção industrial no estado de São Paulo está no desenvolvimento do complexo econômico cafeeiro.

Em outros casos de produção colonial, como a mineração e a cana-de-açúcar, exclusivamente escravagistas, baseadas no esquema casa-grande/senzala, a economia possuía apenas os setores de mercado externo e de subsistência. Nesses casos, a divisão social do trabalho não foi suficiente para criar um setor de mercado interno e as infraestruturas sobre as quais se apoia a indústria. Freyre (1969) aponta que em cidades mineiras o próprio setor de subsistência não era desenvolvido, sendo o problema da fome uma constante que assolava trabalhadores livres e escravos, atendido por importação de comida enlatada. Prado (2010) observa que, nessas condições, a produção de gêneros de consumo interno se tornou insuficiente, obrigando a importação da maior parte até mesmo dos mais vulgares artigos de alimentação.

Por outro lado, nos complexos econômicos agroexportadores (café, cacau e borracha) que se iniciaram no século XIX, a produção voltada para o mercado externo se desenvolveu por um processo de Economia de Escala, intensificando a divisão do trabalho. Segundo Singer (1962), na primeira metade do século XIX o Brasil deve ter possuído uma ampla produção manufatureira de subsistência. O autor encontra base para essa afirmação ao notar que a renda per capta em 1823 era de uma libra por ano e, por isso, a produção manufatureira deveria ser considerável, tendo em vista a baixa capacidade de importação. A formação do setor de mercado interno consistiu na transferência da produção manufatureira de subsistência para o mercado.

A indústria, voltada exclusivamente para o mercado e fundamentalmente para o mercado interno, possuía pouco mais de 50 estabelecimentos em 1850, incluindo salineiras, têxteis, alimentares, fábricas de caixões, metalurgia e produtos químicos. A monetarização da economia se apresenta como meio para realização das relações de troca do mercado interno (SINGER, 1962). 
As condições para a criação da produção voltada para o mercado interno no Brasil foram sendo gestadas nos complexos econômicos agroexportadores, sobretudo do café. Para aumentar o lucro sem necessariamente aumentar a produção, os cafeicultores desenvolveram técnicas para otimizar o processo de produção do café, gerando uma divisão do trabalho em atividades acessórias à produção primária. Essa divisão do trabalho consistia nas seguintes atividades: agricultura produtora de alimentos e matérias primas dentro e fora da lavoura cafeeira; atividade industrial de benefício do café e produção de embalagens de juta; implantação e desenvolvimento do transporte ferroviário; expansão do sistema bancário; atividade de comércio de exportação e importação e introdução de infraestruturas de transporte urbano, de comunicação, de prédios para escolas, comércio, moradia entre outros. Acrescenta-se a isso, a fundação de vilas e municípios, agregando toda a estrutura política ligada ao Estado (CANO, 1983). Assim, ainda que de forma incipiente, surgiram as funções urbanas: indústria, comércio, administração pública, instrução, religião etc.. Na medida em que a produção de alimentos ocorria no campo, e a população do campo recorria ao comércio, serviços e indústrias, as funções urbanas e a produção de alimentos formaram o hinterland econômico da cidade (SINGER, 1968).

Em sua "História da Dualidade Brasileira", Rangel (1981) analisa a produção de café para exportação relacionando-a aos ciclos longos da economia, denominados Ciclos de Kondratiev, e mostra quais conjunturas da economia mundial foram mais ou menos favoráveis para as substituições de importações. Seguindo a razão dos ciclos, o autor mostra que em períodos de prosperidade da economia mundial, a produção para exportação aumenta no Brasil, impulsionada pela demanda exterior, permitindo o aumento de investimentos em atividades acessórias à produção principal, entre as quais a ferrovia é a mais importante. Os períodos de recessão imprimem, na medida das forças de produção instaladas, um esforço de substituição de importações, pois o preço dos produtos importados aumenta em relação aos exportados.

Assim, com o aumento da receita monetária durante o período de produção do complexo cafeeiro na fase ascendente do $2^{\circ}$ ciclo (1851 a 1870), muitos fazendeiros mudaram-se para as cidades, levando consigo a criadagem escrava. A fase depressiva do $2^{\circ}$ ciclo (1871 a 1896) foi a época em que começou a substituição de importação pelo desenvolvimento de atividades urbanas artesanais de transformação e construção civil. 
A fase ascendente do $3^{\circ}$ ciclo (1897 a 1920) associa-se ao máximo desempenho da economia cafeeira, porém, a I Guerra Mundial também induziu um esforço artesanal de substituição de importação (RANGEL, 1981). No entanto, conforme aponta Mello (1982), o ciclo cafeeiro não resulta apenas dos movimentos cíclicos das economias importadoras, mas também de fatores atuantes do lado da oferta, como a disponibilidade de terras agricultáveis e o período de maturação do café. Cano (1983) indica também como variável do lado interno, a disponibilidade de mão de obra, o movimento imigratório e as políticas cambiais e de valorização do café.

Em "Formação Econômica do Brasil", Furtado (2008) aponta que o aumento da renda decorrente da produção de café para exportação induz a expansão do mercado interno. Sendo assim, o mercado interno cresce em função do movimento exportador, seguindo as vagas cíclicas da economia mundial (prosperidade/recessão) em conjunção favorável com as variáveis internas. Nesse sentido, Singer (1968) observa que, enquanto a produção para o mercado interno permanece dependente do aumento da renda proveniente da produção de café, ela apenas desempenha um papel de fornecedora supletiva do fluxo de importações. Em uma economia subdesenvolvida e dependente,

"o processo de desenvolvimento se inicia por uma ruptura estrutural, começando o Setor de Mercado Interno a crescer autonomamente, tornando-se competidor da indústria fornecedora de produtos importados, que ele passa a substituir, até se transformar no setor condutor de toda a economia" (SINGER, 1968:15).

Essa ruptura estrutural ocorreu entre 1930 e 1933, mas foi decorrente de um processo lento que se iniciou com o desenvolvimento de complexos econômicos agroexportadores (CANO, 2002). A intensificação da divisão social do trabalho no interior dos complexos econômicos foi gestando, por força dialética interna, as condições para o desenvolvimento do processo de industrialização e de crescimento das atividades urbanas vinculadas a esse modo de produção dependente. Não ocorreu devido atuação do Estado na economia, mas como consequiência natural do desenvolvimento de uma economia de livre mercado, demonstrando que a formação econômica e social periférica (o Brasil), a despeito de seu caráter dependente, não é passiva ao desenvolvimento da economia das regiões desenvolvidas, pois contém o seu 
próprio polo interno de desenvolvimento convivendo com polo externo, mais desenvolvido.

Para Mamigonian (1969:56), a industrialização brasileira deve muito ao café na medida em que o crescimento da economia cafeeira provocou a ampliação do mercado interno (atendido por artigos importados), a criação de ampla rede de estradas de ferro, a implantação de energia elétrica, etc.. Segundo o autor, entretanto, existe um exagero enganoso sobre o papel da transferência de capitais de empresários de café para a indústria, sendo necessário buscar as causas da industrialização brasileira no imigrante.

Nesse sentido, Dean (1991) aponta que os imigrantes comerciantes importadores estão na origem da criação de um setor industrial no Brasil. Os importadores contribuíram para a instalação de manufaturas, devido às suas posições estratégicas na estrutura do comércio, o que possibilitava acesso ao crédito do exterior, conhecimento do mercado e canais para distribuição do produto acabado, pois o fabricante distribuía seus produtos através dos importadores e não através de atacadistas. Na maioria dos casos, os próprios importadores convertiam suas agências de vendas em fábricas autorizadas ou forneciam crédito para a fabricação nacional, da qual o próprio credor poderia ser o vendedor. "Apenas uns poucos dentre os primeiros empresários industriais não iniciaram suas carreiras como negociantes-importadores” (DEAN, 1991:36).

Inicialmente, as indústrias dos imigrantes fabricaram produtos de difícil transporte (devido ao volume, peso, periculosidade ou por ser perecível), como ferragens, caldeiras, acetileno, biscoitos, pastas, cerveja, material de encanamento, etc..

$\mathrm{O}$ autor elabora uma lista de nomes dos principais industriais que tiveram essa origem, entre os quais se destaca Francisco Matarazzo, que chegou ao Rio de Janeiro com um estoque de banha, que esperava vender, e ingressou no ramo de importação de banha enlatada, arroz e trigo. Em 1900, dezenove anos após chegar ao Brasil, montou uma indústria, caminho que o levaria a ser o maior empresário industrial da América Latina. Nesse processo inicial, o capital financeiro dos comerciantes e dos fazendeiros foi importante para a criação da produção nacional (DEAN, 1991).

A ampliação do setor de crédito chegaria aos consumidores durante a década de 1930, com o intuito de atrair a parcela da sociedade com menor poder aquisitivo. Foi o caso da Loja Mappin (figura 02), inaugurada em São Paulo em 1913 por uma família inglesa. Quando inaugurado, o Mappin era um espaço destinado à elite paulistana, que vendia somente produtos de origem importada, além de disponibilizar serviços como 
barbearia e salão de chá. Com a crise econômica da elite na década de 1930, a empresa criou o crediário para incluir as classes com menor poder aquisitivo no consumo.

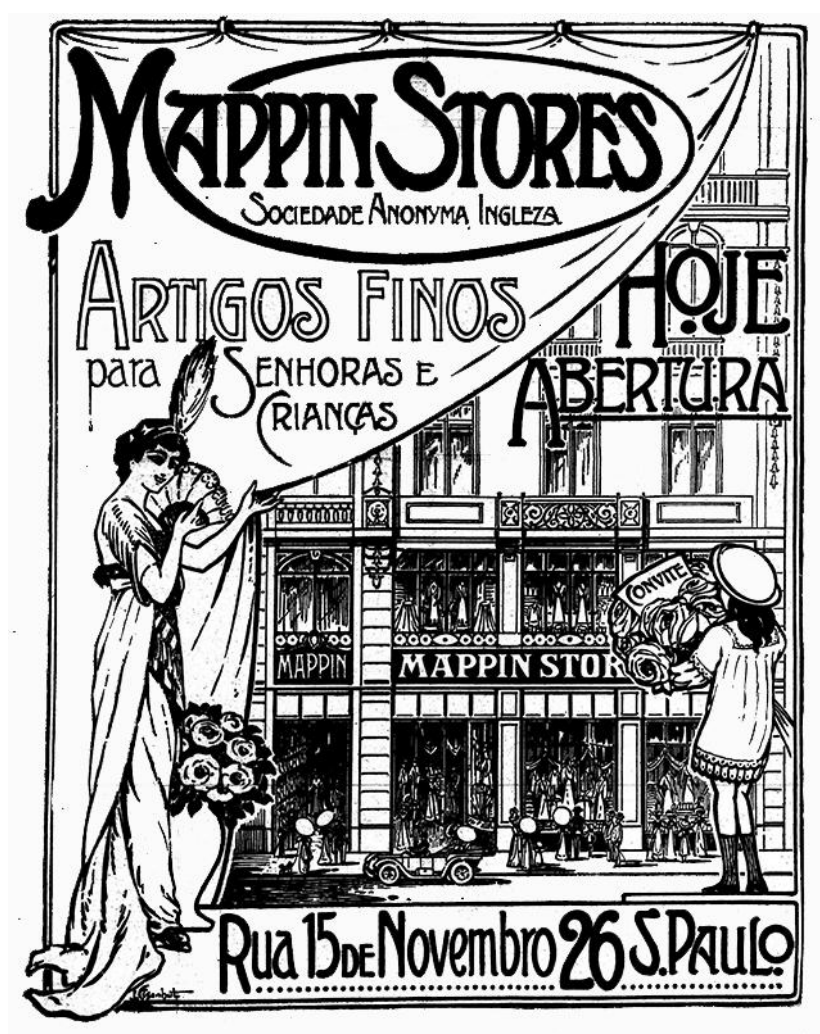

Figura 02: Anúncio de abertura da Loja Mappin em 1913.

Fonte: Em: http://www.saopauloantiga.com.br/mappin/ ${ }^{3}$

Pelo que foi exposto, concluímos que os investimentos realizados pelos cafeicultores, sobretudo em infraestruturas urbanas, juntamente com a produção de mercadorias iniciada por imigrantes comerciantes, geraram acumulação do pequeno capital comercial e manufatureiro, mercado consumidor interno e disponibilidade de mão de obra, i.e., a preparação para a industrialização substitutiva de importações. Conforme mostraremos, as condições políticas para acelerar esse processo foram iniciadas com a Revolução de 1930 e com a adoção de práticas protecionistas de incentivo à indústria nacional.

\footnotetext{
${ }^{3}$ Acesso em janeiro de 2015.
} 


\section{3 - O fácies burocrático da cidade e a formação do urbano}

Durante essa fase preparatória para o desenvolvimento do capitalismo industrial (Império e Primeira República), o Estado Nacional era formado hegemonicamente por fazendeiros agroexportadores, que tomavam decisões em função dos interesses do capital comercial ao qual estavam economicamente subordinados. A classe dos pequenos comerciantes importadores e manufatureiros ganhava importância com o crescimento da economia urbana. Esses haveriam de se aliar aos fazendeiros para promover a industrialização a partir da década de 1930, dando origem a Segunda República, ou Era Vargas (RANGEL, 1982).

Apesar de a economia brasileira ser baseada na agricultura, Oliveira (1982) afirma que o campo nunca controlou o Estado no Brasil. Sua afirmação encontra fundamento em dois fatos históricos: no caráter exportador da monocultura agrícola e na dualidade da estrutura política. Esses dois elementos levam o autor a adotar a ideia de fácies burocrático da cidade, ou seja, a cidade como o local onde se concentra a maioria dos aparelhos de Estado, controladores das relações entre a economia colonial e a economia metropolitana.

\footnotetext{
"É esse caráter de sede do capital comercial que responde, na maioria dos casos, pelo caráter que a urbanização toma por exemplo no Brasil Colônia e depois, já com o país independente, no prosseguimento da expansão da agricultura de exportação sob a égide do café até o final dos anos 20" (OLIVEIRA, 1982:37).
}

Assim, a forma e formação da cidade foram condicionadas, em última instância, por sua posição na estrutura do sistema de produção internacional. Enquanto a produção nacional se resumia à produção agrícola para exportação, o aparelho do Estado Nacional, como parte de um sistema de produção mais amplo, era controlado de fora. Conforme aponta Rangel (1982) os barões-senhores de escravos estavam ligados por laços de suserania-vassalagem ao capitalismo mercantil europeu; internamente eram senhores e externamente, vassalos.

A estrutura vertical da comercialização do café mostra esta dependência. Segundo Mello (1982), a Independência de 1822 implicou no fim do monopólio metropolitano da produção, na formação do Estado Nacional, na nacionalização do excedente de produção e em um estímulo à produção privada. No entanto, o colonizador livre, ao 
plantar sua lavoura cafeeira, ficava subordinado à dominação do capital mercantil, exercido por empréstimos concedido pelos comissários, ou seja, comerciantes que haviam acumulado capital no comércio de mulas e escravos. Estes comissários diversificavam suas atividades fundando bancos e financiando as plantações sob a forma de hipotecas. Assim, cobravam dos fazendeiros uma comissão pela venda, pelas despesas de armazenamento e juros pelo financiamento da plantação. Através das Casas Comissárias, vendiam o café para as firmas exportadoras. Entre as dez maiores firmas exportadoras de café em 1907, apenas uma era brasileira: a Prado Chaves, que ocupava o sétimo lugar. Todas as outras eram estrangeiras, como a Theodor Wille (alemã) e a Neumann \& Gepp (inglesa), sendo que própria cotação do café era manipulada pelos exportadores. O Convênio de Taubaté viria salvar os exportadores, que viam as exportações aumentarem, mas seus lucros não acompanhavam esse aumento (Nosso Século, 1985:100 [volume 01]).

Estabelecia-se assim, um circulo vicioso que consistia em derrubar a mata virgem e empenhar as safras futuras para obter dinheiro para plantar mais café. O círculo se fechava com as vendas do café, que ficavam atreladas ao oligopsônio e oligopólios estrangeiros. Desse modo, o financiamento para novas plantações dependia do maior rendimento das exportações. Mello (1982:69) aponta as mudanças nos agentes da dominação econômica antes e após a independência:

\footnotetext{
"Desaparecera o monopólio do comércio colonial, que conseguia reduzir os lucros retidos pelo setor produtor a quase nada, fixando os preços de venda dos produtos metropolitanos. Surgira em seu lugar o oligopsônio e o oligopólio financeiro, que, manipulando os preços de compra e fixando exorbitantes taxas de juros, terminaram por conduzir ao mesmo resultado, à dominação do capital mercantil."
}

É possível perceber esse controle político e econômico estrangeiro, pela conformação espacial dos núcleos urbanos marcado por uma rede de núcleos urbanos polarizando as funções de sede administrativa da produção agrícola de exportação. A configuração do sistema de transporte ferroviário ligando as cidades ao porto mostra a materialização da relação de subordinação das cidades ao capital comercial exportador. Internamente, esses núcleos urbanos se formavam a partir da estação ferroviária (local de entrada e saída de mercadorias) e as funções urbanas eram limitadas ao atendimento das necessidades da classe dominante: moradia da elite, religião, lojas de importação e 
serviços destinados à elite. Mostraremos especificamente esses fatos quando analisarmos a formação do município de São Carlos.

No entanto, como apontamos, a dinâmica do complexo cafeeiro impulsionava a divisão social do trabalho. O crescimento do hinterland econômico das cidades (produção de alimentos e demais funções urbanas) foi gestando as condições para o surgimento de um espaço urbano qualitativamente diverso. Assim como a industrialização rompeu com o modelo de desenvolvimento agroexportador e o setor de mercado interno passou a ser preponderante na economia, foi também rompido, durante a década de 30, o caráter burocrático das cidades subordinado ao capital comercial exterior. A industrialização tornou o espaço urbano o local da produção e de moradia dos trabalhadores e, ainda nesse contexto, teve início um crescimento da área e da população urbana no Brasil sem precedentes. Nesse sentido, analisaremos nos capítulos 02 e 03, sob vários aspectos, como se dá essa nova relação entre industrialização e urbanização no município de São Carlos. Neste capítulo 01, focaremos em mostrar que, à transição para o capitalismo industrial corresponde uma transição do ponto de vista urbano.

Segundo Rossini (1988:75), foi só a partir de meados do século XIX que a urbanização paulista atingiu a sua maturidade:

“Em 1872, após três séculos e meio de colonização, a população paulista não atingia um milhão de pessoas (837.354 habitantes). A expansão do complexo cafeeiro paulista, a implantação de ferrovias, a substituição do trabalho escravo pelo trabalho livre com o imigrante europeu e a presença do colonato foram as principais causas da ocupação nesse período. O povoamento do planalto ocidental paulista iniciou-se pelas áreas de Ribeirão Preto - Araraquara"

A população paulista atingiu 1.384.753 habitantes em 1890, chegando a 2.282.279 habitantes em 1900, representando um aumento, entre 1872 e 1900, de 272\%. Entre 1900 e 1920 esse crescimento foi de 101,2\%, atingindo 4.592.188 habitantes em 1920, correspondendo a $15 \%$ do total brasileiro. No ano de 1920, a maioria dos municípios produtores de café contava com uma população entre 25 mil e 47 mil habitantes. Na área de Ribeirão Preto-São Carlos, no centro-oeste do estado, entre os vales do rio Mogi e Pardo, assistia-se também um enorme crescimento demográfico (ROSSINI, 1988). 
Essa população, em sua maioria camponeses assalariados, haveriam de constituir o mercado interno.

Segundo Singer (1968:44), a constituição do mercado interno para produtos manufatureiros que se processou no último quarto do século XIX, tomou principalmente a forma de urbanização:

"As cidades crescem em função do movimento exportador, pois elas são a sede de uma série de serviços - transporte, armazenamento, comercialização, embalagem, embarque e desembarque complementares do comércio externo. Estes serviços constituem um terceiro setor da economia, que se distingue do Setor de Mercado Externo, porque sua produção é constituída unicamente para o mercado, não havendo nele quase nenhum autoconsumo. Chamamos a este de 'Setor de Mercado Interno'. Sua dinâmica está, nesta fase, inteiramente na dependência do Setor de Mercado Externo. Aumentando a exportação, aumenta o Setor de Mercado Interno. Diminuindo aquela, diminui este."

Portanto, observando as cidades do interior do estado de São Paulo que cresceram vinculadas ao complexo cafeeiro, percebemos que a formação do setor de mercado interno, o qual assume a forma da urbanização, começa a se concretizar numa relação de dependência da produção primária. Para Santos (1982), a melhor forma de caracterização do fenômeno urbano é através de sua dinâmica funcional, ou seja, da função que desempenha dentro de um sistema mais amplo. Se essa função está direcionada para atender as necessidades da população local, então significa que o urbano se tornou independente da atividade primária que deu origem a aglomeração. A função direcionada para as necessidades da população local implica necessariamente uma divisão social do trabalho ou, em outras palavras, na coalescência de funções. Santos (1982) indica que essa divisão do trabalho pode ser objetivamente analisada através de três variáveis: a população, a renda e o consumo interno. Uma aglomeração em que a população seja numerosa, mas que não disponha de renda e de um mínimo de consumo não pode ser considerada uma cidade, mas uma pseudocidade.

“A 'cidade local' é a dimensão mínima a partir da qual as aglomerações deixam de servir às necessidades da atividade primária para servir às necessidades inadiáveis da população, com verdadeira 'especialização do espaço'” "(SANTOS, 1982:71). 
No sistema da grande lavoura cafeeira, as necessidades de acumulação incluíam componentes intensificadores da divisão social do trabalho e, por consequência, aumento populacional, aumento da renda e do consumo interno. Com o colapso, em 1929, da economia mundial e principalmente dos EUA, para onde se destinava a maior parte do café brasileiro, a maioria das cidades do Oeste Paulista viram a renda proveniente da agricultura minguar, juntamente com um intenso êxodo rural. Assim, a urbanização que se intensifica na década de 1930, independente do excedente primário, mostra que havia rompido a dimensão mínima a partir da qual o fenômeno urbano cresce em função das necessidades do mercado interno. Nesse caso, formação do urbano significa também uma mudança no modo de produção, ou seja, na transição para o capitalismo industrial.

Para Cano (2002:92), a crise de 1929 não constituiu elemento decisivo para por em andamento a industrialização, porém reforçou o processo que já vinha em marcha. Contudo, os anos de 1929 até 1933 deram as condições para que fosse alterado o antigo padrão de acumulação (o modelo primário-exportador) e rompesse definitivamente com a dominância que as exportações exerciam sobre o nível e o ritmo da atividade econômica. A partir de 1933, a economia atinge o mesmo nível de crescimento do ano anterior à crise, agora puxada pelo setor industrial. Em 1939, a economia nacional passa a crescer preponderantemente em função do mercado interno. Nas regiões onde as indústrias não se desenvolveram, as exportações continuaram a ser o elemento dinâmico da economia (CANO, 2002).

\section{4 - Estado moderno e transição para o capitalismo industrial}

"A economia capitalista de troca, com base no mercado, floresce numa liberdade ambígua, que inclui liberdade de consciência, expressão e emprego, ao mesmo tempo que incorpora a liberdade para explorar, para obter lucro privado às custas do Estado e para monopolizar os meios de produção" (HARVEY, 2001:86) 
O Estado que entra em cena no Brasil após a Revolução de 1930 serviu como ferramenta eficaz para o desenvolvimento do capitalismo industrial. Para compreender quais interesses de classe ele representa, ou seja, quem controla o Estado, nos reportamos à análise marxista sobre a formação do Estado Moderno.

Partindo da máxima que "da força material dominante deriva também a ideologia dominante", a teoria marxista busca a origem do Estado moderno no surgimento da sociedade civil e na defesa dos interesses dessa:

"A sociedade civil, como tal, desenvolve-se somente com a burguesia; com este mesmo nome, no entanto, foi continuamente designada a organização social que se desenvolve diretamente a partir da produção e do intercâmbio e que constitui em todos os tempos a base do Estado e da restante superestrutura idealista" (MARX, 1969: 74).

Em outras palavras, com a ascensão da burguesia comercial e industrial, o Estado tornou-se a forma de organização social destinada à garantia do desenvolvimento capitalista. Assim, o nascimento da sociedade civil, propriamente dita, refere-se à ascensão da burguesia e o Estado Moderno aparece como a instituição que garante a hegemonia dos interesses dessa burguesia.

Segundo Harvey (2001), em um sistema baseado no interesse próprio e na competição, o Estado assume as responsabilidades para a manutenção desse sistema, o que capitalista algum se disporia a prover com o seu lucro. Por isso

“o estado capitalista também tem de funcionar como veículo pelo qual os interesses de classe dos capitalistas se expressam em todos os campos da produção, da circulação e da troca" (HARVEY, 2001:85).

As funções do Estado no sistema capitalista industrial passam a ser: a regulação da competição e da exploração do trabalho; o fornecimento de infraestruturas sociais e físicas necessários para reprodução capitalista; o envolvimento em momentos de crise do sistema, para evitar perdas de lucro (HARVEY, 2001).

Ao desenvolver suas relações de produção industrial na periferia da economia mundial, a formação socioespacial brasileira combinou elementos do mundo desenvolvido e subdesenvolvido. Por conseguinte, a formação do Estado teve sua 
especificidade própria ao conciliar a herança produtiva e ideológica da antiga elite agrária, com os novos interesses da burguesia comercial e industrial e da nova classe média urbana. Embora os latifundiários tenham cedido espaço no controle do aparelho do Estado para o setor industrial, a estrutura da propriedade da terra baseada na grande propriedade e na alta taxa de exploração da mão de obra assalariada não foi alterada, convivendo a produção agrícola extensiva com as novas relações de produção industriais baseada no esquema de substituição de importação.

Assim, o fato de se constituírem relações de produção capitalistas não significou ocorrência de revolução burguesa.

“Tal processo histórico - o da revolução burguesa - inscreveu-se nas definições de Marx numa luta, por um lado, econômica, e por outro, política, de uma classe social - a burguesia - quando esta se desvencilhava e destruía os laços da sociedade feudal" (DE DECCA, 1981:55).

De Decca (1981), problematizou essa questão da revolução no Brasil se reportando às análises de Lênin na obra "O desenvolvimento do capitalismo na Rússia", na qual o autor aborda a questão do processo de formação do mercado interno para a grande indústria:

\begin{abstract}
"Analisando mais de perto essa obra de Lênin, podemos perceber que a questão da revolução burguesa permite dois desdobramentos. No primeiro deles, o desfecho revolucionário, dando-se sob a direção do partido revolucionário, assumiria a forma de uma revolução democrático-burguesa; e no segundo, tal revolução ocorreria pelo “alto", perdendo, portanto, seu caráter democrático, já que a direção política deslocar-se-ia para o âmbito das velhas "superestruturas", com a conseqüente derrota do partido revolucionário" (DE DECCA, 1981:59).
\end{abstract}

Nesse último caso, a passagem para a economia capitalista se dá mediante uma acomodação da propriedade da terra baseada no latifúndio, tal como se manteve na etapa de transição para o capitalismo industrial no Brasil. Segundo Fausto (Caderno Cebrap 10$)^{4}$, a capacidade de articulação da burguesia do café durante o período da $1^{\text {a }}$ República forjou as instituições estatais e as transformou no instrumento de seus interesses, enquanto os setores industriais se constituíam adaptados ao centro agrário-

\footnotetext{
${ }^{4}$ Em: http://www.cebrap.org.br/v2/items/view/205 (acesso em janeiro de 2015).
} 
exportador. Durante a $1^{\mathrm{a}}$ República, os grupos da baixa classe média não puderam encontrar formas organizatórias de expressão e o movimento operário não conseguiu se tornar polo de atração. Entretanto, durante os anos 20, quando os adversários eram os tenentes, a oligarquia (representada pelo Partido Democrático) procurou fazer uma ponte em direção ao proletariado.

Nas três primeiras décadas do século XX, surgem as reivindicações dos operários das fábricas concentradas apenas nos polos industriais da época, pois no restante do Brasil, como no interior paulista, os movimentos ficavam muito dispersos devido ao isolamento geográfico dos sindicatos, quando existiam; já os trabalhadores rurais, ignorantes e analfabetos, eram facilmente dominados pelos latifundiários (FAUSTO, 1986). Contudo, foi no começo do século XX que os trabalhadores industriais começavam a se constituir como classe, formando sindicatos e fazendo greves. Foi nesse contexto que começou se constituir a legislação trabalhista das indústrias.

Segundo Fausto (1986:217),

$$
\begin{aligned}
& \text { "o ascenso do movimento operário nos anos 1917-1920 coloca pela } \\
& \text { primeira vez a "questão social" na cena política. Nem os industriais, } \\
& \text { nem o Estado oligárquico, nem outros grupos da sociedade podem } \\
& \text { ignorá-la como tinham feito em larga medida até então". }
\end{aligned}
$$

A Questão Social, que era reivindicada com greves e manifestações públicas pela massa trabalhadora, referia-se às melhores condições de trabalho nas fábricas, como legislação específica sobre acidentes de trabalho, horas trabalhadas, nível do salário e regulamentação do trabalho menor. Referiam-se, portanto, àquilo que nos países industrializados se tornaram o mote das revoluções. Aqui, os capitalistas brasileiros começavam a ceder às reinvindicações, mas não sem muita resistência e muitas vezes apenas como formalização, pois na prática só passaram a ser cumpridas décadas mais tarde.

Com a Revolução de 30, os interesses ficaram divididos entre a oligarquia agrária e a industrial e, em segundo plano, a classe média urbana e os ultraexplorados trabalhadores do campo e das indústrias. Foi nessa conjuntura que o governo Vargas, como representante da Aliança Liberal interessada pela industrialização e pela Questão Social, governou o Brasil agitado pelas movimentações operárias nos primeiros anos da década de 1930, usando o populismo como estratégia política da nova relação entre o poder estatal e a classe operária. Segundo Oliveira, o populismo foi a estratégia da 
nascente burguesia industrial que usou o apoio da classe trabalhadora urbana para liquidar politicamente as antigas classes proprietárias rurais. O populismo começou por estabelecer a aliança entre o arcaico e o novo, fundando novas formas de relação entre capital e trabalho, a fim de criar as fontes internas de acumulação (OLIVEIRA,1987).

Portanto, o Estado passou a atuar sobretudo na provisão de infraestruturas para indústria, na consolidação da legislação trabalhista, na formação da mão de obra e até mesmo atuando na produção industrial, indiretamente com financiamentos de bancos públicos ao setor produtivo, ou diretamente com implantação de indústrias de base.

Como resultado, o crescimento industrial, que vinha ocorrendo timidamente na década de 1920, foi acelerado após 1930, como alternativa à crise econômica do setor agroexportador. O Brasil, sendo um país exportador de produtos agrícolas e importador de bens de consumo, começou seu processo de industrialização com uma crise agrícola e com substituição de bens de consumo, principalmente com o setor têxtil, se aproximando, setor após setor, dos bens de produção (RANGEL, 1986).

Confirmando essa lógica macroeconômica, dados da economia mostram que as importações brasileiras caíram de US\$ 416,6 milhões em 1929, para US\$108,1 milhões em 1932 (BAER, 1977:16). Analisando um período maior, o coeficiente de exportação no Brasil passou de 9,1\% em 1939 para 7,3\% em 1950. Nas mesmas datas, a exportação no estado de São Paulo passou de 23,9\% para $15 \%$. Ao mesmo tempo, no estado de São Paulo, o comércio interno adquiriu maior importância quantitativa em relação ao externo. Sobre o total do valor exportado, o comércio interno, que representava $37,3 \%$ em 1928, passou para 43,3\% em 1939 e 57\% em 1955 (NEGRI, 1996). Portanto, na década de 1930, as importações caíram e o consumo interno cresceu, sendo que a partir de 1939 a economia passou a crescer preponderantemente em função do mercado interno, devido principalmente à produção industrial.

Um levantamento de dados mostra que, a partir de 1933, iniciou-se a recuperação da economia brasileira puxada pelo setor industrial de bens de consumo, que crescia a uma média nacional de 11,2\% a.a. entre 1933 e 1939, enquanto que a indústria paulista, que concentrava produção nacional, crescia a 14\% no mesmo período (NEGRI, 1996:67). O ramo principal da indústria nessa etapa era o têxtil, mas durante o período da $2^{\mathrm{a}}$ Guerra, além das indústrias têxteis, também foram favorecidos os ramos de cimento, ferro e metalurgia, que tiveram grande impulso (BAER, 1977).

Esse comportamento de substituição de importações foi estudado por Rangel (1985). Com o crescimento do mercado interno, o economista detectou um novo centro 
dinâmico na economia, que, por sua regularidade desempenhada na economia brasileira, foi estudado como um ciclo. Esse ciclo breve (em média de 10 anos) modula o ciclo longo (com duração media de 50 anos, sendo 25 anos de expansão da economia mundial e 25 anos de recessão) e soma-se a ele no sentido de impelir a industrialização, de tal maneira que a cada ciclo breve, um novo setor de importação é substituído pela indústria nacional, passando pelos bens de consumo não duráveis, para os duráveis até introduzir um Departamento I na indústria nacional, isto é, o setor de insumos e bens de produção.

O fato de a produção de bens de consumo nacional ter se desenvolvido na quase ausência de um Departamento I e com capacidade de importação reduzida, é explicada pela introdução de segmentos industriais tecnologicamente mais simples e pela sustentação desse sistema na intensa exploração do trabalho. As interpretações sobre a industrialização brasileira acentuam que, ao se desenvolver na periferia da economia mundial, o processo de acumulação que permitiu a rápida reprodução do capital industrial se apoiou na alta taxa de exploração do trabalho, o que permitiu novos investimentos ao mesmo tempo em que, ao criar postos de trabalho, ampliava o mercado interno para bens de consumo e a importação de bens de produção.

Com o desenvolvimento industrial durante a década de 1930, a estrutura espacial da indústria brasileira ficou concentrada no estado de São Paulo, que tinha como polo de produção a capital do estado. Alguns autores apontaram elementos para explicar as causas dessa concentração industrial. Nas palavras de Edgar de Decca,

"a industrialização entendida como o desenvolvimento das forças produtivas - potência social do capital criando meios de produção torna-se possível a partir do próprio mercado interior e o capitalismo pode se desenvolver na medida em que faz crescer esse mesmo mercado, intensificando a divisão social do trabalho" (DECCA, 1981, p.118).

Para Furtado (2008:165), o desenvolvimento econômico com base no mercado interno só se torna possível quando o organismo econômico alcança um determinado grau de complexidade, que se caracteriza por uma relativa autonomia tecnológica. Rattner (1972:24) indica, entre os fatores que tiveram influência preponderante na fase inicial de industrialização e do posterior crescimento urbano da região metropolitana de São Paulo, i) a existência de capitais acumulados a procura de investimentos, ii) a 
concentração do imigrante trazendo consigo seu Know-how, iii) a posição geográfica estratégica e condições climáticas favoráveis e, finalmente, iv) a concentração de energia elétrica com preços relativamente baixos. Entre os fatores acima apontados, que favoreceram o estado de São Paulo, a capital paulista certamente foi o lugar privilegiado de concentração, além de, ela própria, formar importante mercado consumidor. Todos esses pontos favoráveis explicam a concentração da indústria no estado, sobretudo na área representada pelo mapa abaixo.

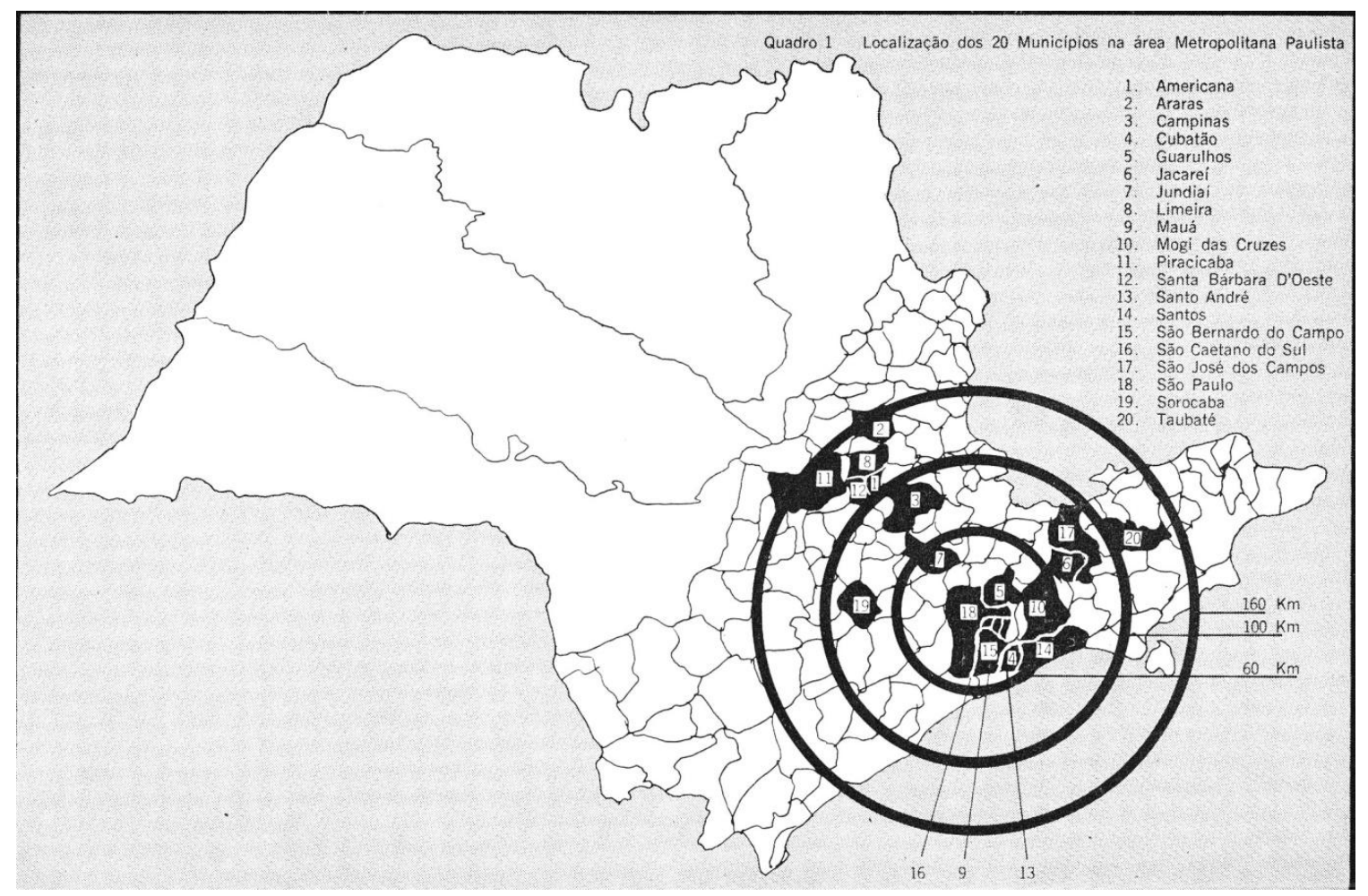

Mapa 06: Concentração da produção industrial no estado de São Paulo em 1930. Fonte: Rattner, 1972:06.

Entre 1920 e 1950, os 20 municípios em destaque no mapa, o que representa apenas $4,9 \%$ da área total do estado, passaram de $31,2 \%$ para $41,5 \%$ do número de operários total do estado, de $32,3 \%$ para $40,2 \%$ da força motriz e de $31,5 \%$ para $43,4 \%$ do valor da produção (IBGE. Censos de 1920, 1940, 1950, apud RATTNER, 1972:27). Essa concentração pode ser observada qualitativamente pois, à medida em que se desenvolvem os ramos mais sofisticados, essa produção se concentra na capital.

Segundo Rattner (1972:50),

"as indústrias dinâmicas produzem com índices mais elevados de capitalização e, aproveitando os progressos tecnológicos, 
correspondem também a uma estrutura mais diversificada da procura interna, orientada para bens de consumo duráveis, insumos e bens de capital. À medida que se processa o desenvolvimento econômico e industrial, este grupo de atividade tende a suplantar o de atividades tradicionais, tanto em valor da produção, quanto do número de empregados".

Seguindo essa lógica, dados estatísticos mostram que, embora a produção de bens de consumo não duráveis representasse a maioria da produção nacional, durante a década de 1930, os setores da indústria que mais cresceram no Brasil foi o de bens de capital e de bens de consumo duráveis, com taxas de crescimento de $12 \%$ ao ano. Em segundo plano ficaram os de bens intermediários, com $7 \%$ ao ano, enquanto que as indústrias de bens de consumo não duráveis cresceram menos de 5\% ao ano. Mesmo assim, em 1939 as indústrias têxteis e de alimentos ainda representavam $45 \%$ da produção nacional (NEGRI, 1996:60).

O intenso crescimento das indústrias de bens de capital e de consumo duráveis, durante a década de 1930, deve-se à montagem de caminhões e ônibus por empresas estrangeiras e também à fabricação de motores elétricos, máquinas e equipamentos para agricultura. Entre os ramos de bens intermediários, os que mais cresceram foram as indústrias químicas - derivados de petróleo e carvão, fỉos artificiais e matérias plásticas, óleos e essências vegetais, matérias graxas animais e farmacêuticas - e metalúrgicas siderurgia e metalurgia dos não ferrosos como cimento, cal e beneficiamento de minerais não metálicos (HADDAD, 1978, apud NEGRI, 1996:61).

Outro fator importante na década de 1930 foi o crescimento da indústria no interior do estado. $\mathrm{O}$ valor da produção em relação à produção paulista passou de $28,4 \% \mathrm{em}$ 1928, para 35,5\% em 1937, sendo que os ramos que mais cresceram foram de minerais não metálicos e materiais de transporte. Em segundo plano ficaram as indústrias de metalurgia, mecânica, madeira e mobiliário. Apesar desse crescimento, a produção industrial do interior paulista ainda estava concentrada nos ramos de alimentos, têxtil e químico. A agropecuária do interior, sendo a mais dinâmica e diversificada do estado, estimulou, durante as décadas de 1930 e 1940, a produção agroindustrial de beneficiamento de café, arroz, milho, frigoríficos e produção de álcool e açúcar. A produção têxtil também se beneficiou da agricultura (NEGRI, 1996:84). 
Assim como a produção nacional era concentrada no estado de São Paulo, a produção paulista se concentrava na Capital do estado, e, na década de 1940, essa concentração se acentuou. A microrregião de São Carlos (formada pelos municípios de Analândia, Descalvado, Dourado, Ibaté, Ribeirão Bonito e São Carlos) contava com 2,19\% da produção industrial paulista em 1939, mas diminuiu para 1,63\% dez anos depois. No ano de 1940, a Grande São Paulo participava com 62,3\% da produção estadual, passando para 72\% em 1950 (DEVESCOVI, 1987:117). Segundo estatística de 1939 acerca dos impostos sobre indústrias no estado de São Paulo (ESTATISTICA INDUSTRIAL, 1938/1939), a Capital do estado era responsável por 67,25\% dos impostos, enquanto São Carlos apenas 0,26\%.

Em 1939, a produção da indústria de bens não duráveis no estado de São Paulo correspondia a 37,6\% da produção nacional, dividida da seguinte forma: ramo têxtil, 51\%; ramo de mobiliário, 41\%; no ramo alimentício, $25 \%$. No setor de bens intermediários a concentração ainda era maior, de 40,9\%. Mas a concentração mais acentuada estava no setor de bens de capital e de bens de consumo duráveis, com $72 \%$ da produção nacional em 1939. Como se observa, quanto mais sofisticado o setor da indústria no quesito tecnológico, mais se concentrava no estado de São Paulo. Contudo, cabe salientar que nesse período de "industrialização restringida", a proporção da produção entre os setores estava dividida da seguinte forma: bens de consumo não duráveis, 62,3\%; bens intermediários, 26\%; bens de capital e de consumo duráveis, 11\%; Na década de 1940, as taxas de crescimento no estado continuaram elevadas em todos os setores, seguindo a mesma lógica da década anterior. Em relação à produção nacional, houve ampliação da participação dos setores de bens intermediários, bens de capital e de consumo duráveis. Ampliou-se também a concentração da produção na indústria paulista (NEGRI, 1996:64).

Na década 1940, a indústria nacional cresceu a uma taxa média anual de 7,8\%. Os setores que mais cresceram, assim como na década anterior, continuaram sendo as indústrias de bens intermediários (10\%) e de bens de consumo duráveis $(9,3 \%)$. A indústria de bens de consumo não duráveis, puxada pela indústria têxtil, que foi favorecida pela conjuntura da $2^{\mathrm{a}}$ Guerra, teve um crescimento maior do que na década passada, $6,7 \%$ contra menos de $5 \%$. Portanto, nas duas décadas, os setores que mais tiveram crescimento foram os de bens intermediários e de bens de consumo duráveis. Mesmo com todas as mudanças durante essas duas décadas, as indústrias têxteis e de 
alimentos ainda eram as mais representativas no total da produção nacional no ano de 1949 (CANO, 1985, apud NEGRI, 1996:61).

A partir da consolidação do setor de bens de consumo e início da produção de bens de capital na década de 1950, a economia mundial entrava novamente em fase expansiva (1948-73). Se, durante a fase recessiva o esforço de substituição de importações (de bens de consumo) sobreveio como uma necessidade, pelos motivos já mencionados, apoiado na abundante exploração do trabalho, na fase de expansão o processo continuou, com a implantação do setor de bens de capital. Rangel (1986:31), aponta dois fatos que contribuíram para a continuação do processo a despeito da conjuntura não favorável para a industrialização na periferia do sistema: i) a reativação do comércio internacional ocorreu entre os próprios países desenvolvidos, sendo que o Brasil manteve suas exportações constantes entre 1950 (US\$ 1.085 milhões) e 1965 (US\$ 1.096 milhões); ii) no mesmo período, o PIB nacional e industrial continuou crescendo em um descompasso acima da capacidade de importar, o que induziu a produção de bens de capital internamente. Portanto, na fase expansiva da economia mundial, a indústria brasileira cresceu em função de seu mercado interno. A esses fatores deve-se acrescentar ainda a gradativa industrialização da produção primária que estimulou a produção de bens de capital. A tabela abaixo mostra que as importações brasileiras diminuíram drasticamente em todos os setores industriais.

Tabela 02: Importações brasileiras com uma percentagem da oferta total.

\begin{tabular}{|l|c|c|c|c|c|c|}
\hline & $\mathbf{1 9 4 9}$ & $\mathbf{1 9 5 5}$ & $\mathbf{1 9 6 0}$ & $\mathbf{1 9 6 2}$ & $\mathbf{1 9 6 5}$ & $\mathbf{1 9 6 6}$ \\
\hline Bens intermediários & 59,0 & 43,2 & 23,4 & 12,9 & 8,2 & 13,7 \\
\hline Bens de capital & 25,9 & 17,9 & 11,9 & 8,9 & 6,3 & 6,8 \\
\hline Bens de consumo & 10,0 & 12,2 & 4,5 & 1,1 & 1,2 & 1,6 \\
\hline
\end{tabular}

Fonte: A industrialização brasileira: diagnóstico e perspectiva. Estudo Especial. Programa Estratégico de Desenvolvimento. 1968 - 1970. Ministério do Planejamento e Coordenação Geral, jan. 1969, apud BAER:302.

Em relação ao comércio interno, Negri (1996:71) aponta dados que mostram a evolução quantitativa do mercado interno em relação ao total exportado no estado de São Paulo. Em 1928, o comércio interno representava 37,3\% do total das exportações; 
em 1939, 43,3\%; e em 1955, 57\%, superando o valor das exportações. O crescimento da economia e a continuação do processo de industrialização em uma economia periférica que crescia "para dentro" mesmo em condições não muito propícias (fase expansiva da economia mundial) coloca em relevo i) a introdução dos ciclos curtos na lógica do processo, ii) as medidas tomadas pelo governo, que se lançou num vasto programa dedicado a construção e melhoramento de infraestruturas para a indústria, e iii) a associação com o capital estrangeiro em alguns ramos da indústria.

Mesmo com a atuação estatal no incentivo à industrialização, a partir de 1962, a indústria nacional se desaqueceu e a inflação aumentou, o que, doravante, se tornou um problema crônico e um desafio para o governo. Conforme mostra a tabela abaixo, a inflação aumentou enquanto a produção industrial diminuiu de crescimento. A partir de 1964, com a recuperação da indústria, a inflação começou a diminuir.

\begin{tabular}{|c|c|c|}
\hline \multicolumn{3}{|c|}{$\begin{array}{l}\text { Tabela 03: Evolução da produção industrial e da inflação entre } \\
\text { 1958 e 1965 }\end{array}$} \\
\hline ANOS & $\begin{array}{c}\text { PROD. INDUSTRIAL } \\
\% \text { a.a. }\end{array}$ & $\begin{array}{c}\text { INFLAÇÃO } \\
\% \text { a.a. }\end{array}$ \\
\hline 1958 & 16,2 & 14,4 \\
\hline 1959 & 11,9 & 33,5 \\
\hline 1960 & 9,6 & 17,3 \\
\hline 1961 & 10,6 & 43,6 \\
\hline 1962 & 7,8 & 42,2 \\
\hline 1963 & 0,2 & 88,4 \\
\hline 1964 & 5,2 & 82,2 \\
\hline 1965 & 5,0 & 69,7 \\
\hline
\end{tabular}

Fonte: Conjuntura Econômica, vol. 30, n. 3, mar. 76, apud Rangel, 1985: 41

Nesse novo contexto da economia mundial, ou seja, em sua fase expansiva, a indústria paulista continuou seu crescimento à frente da indústria nacional, exceção feita ao setor de transportes, devido ao dinamismo da indústria naval e da Fábrica Nacional de Motores do Rio de Janeiro. Em 1955, os setores industriais estavam distribuídos da seguinte maneira no estado de São Paulo: o setor de bens de consumo não duráveis representava $45,4 \%$ da produção total; o de bens intermediários, 38,2\% e o de bens de 
capital e de consumo duráveis, $16,4 \%$, sendo que em todos os setores houve aumento da concentração no estado de São Paulo (NEGRI, 1996:71). Portanto, observa-se um gradativo aumento da produção em direção aos setores mais avançados no quesito de tecnologia de produção.

Assim como o período da industrialização restringida (1930-1955), durante a primeira fase da industrialização pesada, (1956-1967), a indústria no Brasil continuava concentrada no estado de São Paulo, tanto no que se refere ao total da produção, como à localização dos estabelecimentos e ao número de empregados industriais. Do mesmo modo, dentro do estado, a produção estava concentrada na Grande São Paulo, sendo que as taxas de crescimento anuais acentuavam essa concentração. $\mathrm{O}$ período em que se verifica um processo de desconcentração e descentralização espacial, i.e, de um crescimento maior rumo ao interior do estado, seguindo, principalmente, os grandes eixos rodoviários, tem início no ano de 1967 (NEGRI, 1996). Apesar de permanecer o processo de concentração, ocorrem algumas mudanças em relação ao período compreendido entre 1930 e 1955 . Havia começado a primeira fase da industrialização pesada, devido à importância que os setores de bens de consumo duráveis, bens intermediários e de capital passavam a desempenhar no crescimento econômico.

As características dessa fase são: i) intensificação da produção de bens de capital, bens intermediários e bens de consumo duráveis, e ii) consolidação dos estabelecimentos de grande porte, detentores de grande parcela da produção industrial, com um patamar mais sofisticado de produção, gerenciamento e atendimento de mercados. Segundo Rattner (1972:97), a concentração da produção em grandes empresas é um processo histórico inevitável na medida em que a ampliação e diversificação do parque industrial cria as condições propícias para realizar economia de escala. Por disporem de mais recursos financeiros, reúnem mais equipamentos, mão de obra e capital ao seu controle. Além da esfera puramente econômica, acrescentam-se as práticas anticompetitivas, como formação de trustes e cartéis.

A despeito da diversificação da produção, as indústrias de bens de consumo, também se desenvolveram durante a segunda metade da década de 1950. Entretanto, as que mais cresceram foram as de bens intermediários e bens de capital. No período de industrialização mais intensa, entre 1956 e 1962, a taxa anual de crescimento do produto real foi de $7,8 \%$, com a indústria crescendo a $10,3 \%$ ao ano e a agricultura crescendo apenas $5 \%$. Os principais ramos da indústria responsáveis por esse crescimento foram o metalúrgico, o de materiais elétricos, o de material de transporte e a indústria química 
(BAER, 1975:300). Conforme apontado no item anterior, nessa etapa, as taxas de importações desses setores caíam drasticamente, se elevando sensivelmente a partir de 1966.

Segundo dados dos censos industriais (apud NEGRI, 1996:103), na segunda metade da década de 1950, os principais segmentos que cresceram foram de materiais de transportes (tendo à frente a indústria automobilística), de material elétrico e de bens de capital (principalmente máquinas, ferramentas, equipamentos sob encomenda e máquinas e implementos agrícolas). Toda essa produção se instalou predominantemente na Grande São Paulo, com forte presença de investimentos estrangeiros. O setor de bens intermediários cresceu devido à produção da indústria petroquímica, siderúrgica e de energia elétrica, com investimentos diretos do Estado. 
CAPÍTULO 02 - INDUSTRIALIZAÇÃO E TRANSFORMAÇÃO SOCIOESPACIAL EM SÃO CARLOS NAS DÉCADAS DE 1930 A 1960 


\section{1 - Expansão urbana e desenvolvimento econômico em São Carlos até 1929}

"Contam que os territórios hoje ocupados pelas comarcas de São Carlos e Araraquara, eram medonhos sertões habitados por índios até 1786, quando Carlos Bartholomeu de Arruda adquiriu a sesmaria do Pinhal (atual município de São Carlos) pela insignificante quantia de $30 \$ 960$ réis... Em 1802, começou a affluir levas de aventureiros attrahidos pela uberdade das terras".

Essa descrição de autoria do advogado Theodorico de Camargo, publicada no “Alamanck de São Carlos” em 1917, ilustra o início da ocupação das terras que formam o município de São Carlos. Segundo Neves (1984), foi o sargento-mor Carlos Bartolomeu de Arruda Botelho o responsável pela abertura, a partir de 1799, do chamado "Picadão de Cuiabá", devido ao interesse na extração do ouro em Mato Grosso. Saindo de Piracicaba, que era a "boca do sertão", esse caminho atravessava a mata do Pinhal, onde atualmente está o núcleo urbano de São Carlos, e atingia a margem direita do rio Tietê. A abertura desse caminho deu ensejo à vinda de posseiros, com a introdução de economia de subsistência, como plantações de arroz, milho, feijão, mandioca e criação de animais, cuja venda do toucinho do porco era a principal fonte de riqueza (BRAGA, 1894, In: ALMANACH DE 1894, 2007).

Na segunda metade século XIX, a disponibilidade de terras e as condições naturais (climáticas e geomorfológicas), do Oeste Paulista foram fatores de atração para a introdução da cafeicultura e desenvolvimento do urbano. Conforme descreve Neves $(2007: 23)$

\footnotetext{
"as terras que hoje constituem o município de São Carlos localizamse nas bordas do planalto ocidental paulista, último contraforte da larga rechã arenítico-basáltica meridional”.
}

Trata-se (a larga rechã) da Serra Geral, que se estende do sul do Brasil até o Oeste Paulista. O intemperismo basáltico nessa área deu origem aos férteis solos chamados de Terra Roxa. A aquisição das terras para o plantio do café foi estimulada pelas concessões de serviços (cartas de sesmarias para cultivo da terra), expulsando a maior 
parte dos posseiros. Apenas uma pequena parcela deles foi aproveitada nas plantações de café (TRUZZI, 2000).

Aproveitando a abertura das picadas e a doação das cartas de sesmarias, os donatários, que procuravam novas terras férteis para o plantio do café, aos poucos estabeleciam oficialmente as vilas - alguns, inclusive, após adquirirem, as vendiam, gerando uma incipiente especulação pela compra de terras (BRAGA, 1894). Inicialmente, as terras do atual município de São Carlos foram integradas politicamente ao município de Araraquara, vila desde 24 de agosto de 1833. Em 20 de abril de 1857, foi criado o Distrito de Paz e, logo no dia seguinte, a Câmara de Araraquara determinou ao arruador que procedesse ao alinhamento para construir o cemitério. Em 1865, o Distrito foi elevado à categoria de Vila e em 1880 a de Município (NEVES, 1984). A data oficial de fundação é o 4 de novembro de 1857, em homenagem a São Carlos Borromeu, santo italiano padroeiro da cidade.

Para o historiador e político são-carlense, Ary P. das Neves (NEVES, 1984) o município de São Carlos possui três períodos em sua história. A São Carlos iniciada com sua fundação política, de casas de barro e de palha, modestas e improvisadas em torno do pátio da capela; a São Carlos da estrada de ferro, de tijolos e de telhas, com nobres sobrados de cafeicultores, que se inicia em 1884; e a São Carlos do presente, de edifícios de concreto armado e aço, simbolizada por sua imensa catedral. Essa fase data da demolição e reconstrução do templo, iniciado em 1949.

No primeiro período surgem as primeiras ruas, cujo eixo principal era a rua São Carlos no sentido norte-sul. Até 1868, a área urbana permaneceu limitada à metade sul do pátio da Matriz, quando, através da doação de Dona Alexandrina de uma parte da sesmaria do Pinhal, a vila se estendeu para o alto da colina, com o prolongamento da rua São Carlos e abertura das transversais. Até a implantação da ferrovia, em 1884, embora os fazendeiros possuíssem casas na cidade, continuavam a residir na casa-grande em suas fazendas, tendo em vista a pouca infraestrutura e a pobreza da população (NEVES, 1984). A figura abaixo mostra a rua São Carlos em sua metade sul no ano de 1866. 


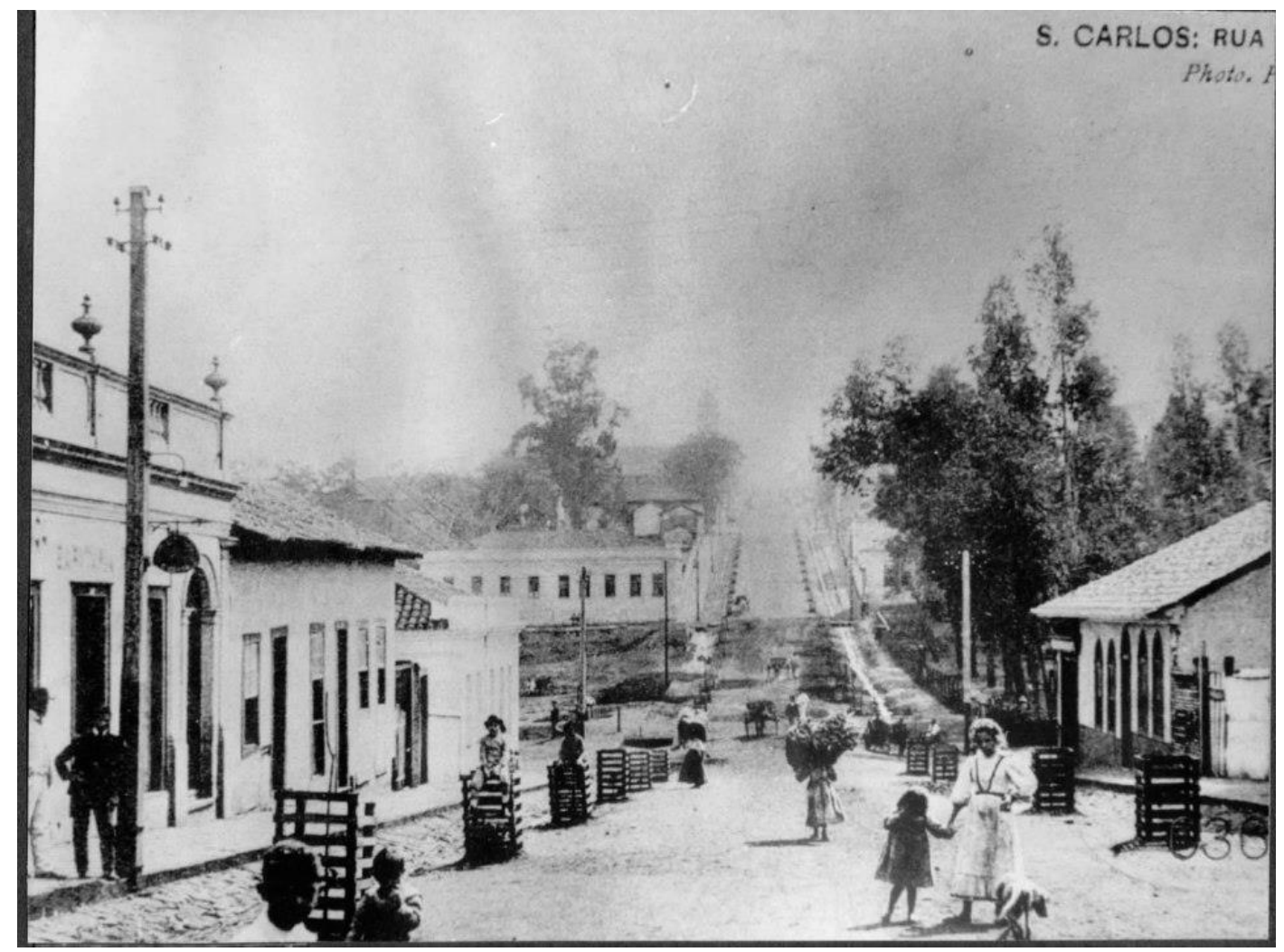

Figura 03: Vista da rua São Carlos em 1866.

Fonte: Prefeitura Municipal de São Carlos. Fundação Pró-Memória.

Em 1883, o fazendeiro de café Antonio Carlos de Arruda Botelho, já deputado provincial e detentor do nobre título de Visconde do Pinhal, conseguiu superar os obstáculos e obteve a aprovação do Império para a construção da estrada de ferro. Devido ao alto custo da implantação, optou pela bitola estreita. Em 15 de outubro de 1884, a estação ferroviária, localizada no extremo sul da malha urbana, foi oficialmente inaugurada em São Carlos. Os trilhos, que tangenciavam a cidade na parte sul, não deveriam parar em Araraquara, mas seguir até Guatapará, onde o Conde do Pinhal havia recentemente comprado terras. De São Carlos deveriam também partir ramais para Santa Eudóxia, Ribeirão Bonito e Dourado (NEVES, 1984). A partir de então, a área central de São Carlos modifica-se, com a implantação de infraestruturas e a substituição de prédios acanhados e mal construídos por outros com arquitetura mais elaborada. É a época em que os grandes cafeicultores mudam para cidade, então transformada em sede administrativa da produção cafeeira. É também o local onde se estabelece relação com São Paulo, Rio de Janeiro e as grandes cidades do exterior, como Paris, Londres, Nova Iorque, etc. (MONBEIG, 1998). 
As transformações, portanto, ganham enorme impulso com o trem que trazia materiais importados da Europa. Surgem os prédios públicos e privados (Câmara Municipal, Cadeia Pública, casas, escolas, teatro, hospital, lojas, etc.) ornamentados com materiais importados, segundo a estética e o gosto europeu, convivendo com o hábito rural local, como o de manter amplos quintais com pomares e criação de animais dentro da cidade (FREYRE, 1977).

A partir de 1889, com o forte desempenho do complexo cafeeiro e a implantação da ferrovia, a área urbana se expandiu e houve também a implantação dos primeiros loteamentos, sob controle da Câmara Municipal que impunha regras rígidas de arruamento e demarcação dos lotes através dos Códigos de Posturas.

O primeiro loteamento de terras privadas foi a Vila Nery, em 1889, ao nordeste da área central, seguindo como eixo principal a rua Padre Teixeira. Em 1891, uma chácara ao noroeste dos primeiros arruamentos foi loteada e ganhou o nome de Vila Puresa. Era um prolongamento principalmente das ruas 15 de Novembro e Carlos Botelho. No mesmo ano, outra chácara foi loteada na parte sudeste e ganhou o nome de Vila Isabel. Inicialmente, este loteamento possuía 16 quarteirões e no meio uma praça onde foi erguida a capela de Santa Isabel. Em 1893, o coronel Leopoldo de Almeida Prado, um político e fazendeiro de São Carlos, loteou parte dos campos além da ferrovia e vendeu os lotes a preços módicos para as famílias de ferroviários interessados em morar perto do local de trabalho. Assim como a Vila Isabel, a Vila Prado rompeu com o traçado urbano de ruas paralelas e transversais à rua São Carlos. Logo seria esta a região mais populosa da cidade, abrigando, em sua maioria, operários (NEVES, 1984). Assim, se formou a área urbana, com os primeiros arruamentos e quatro loteamentos implantados nos quatro cantos da cidade, totalizando 363 hectares, divididos da seguinte forma: área que atualmente corresponde ao centro com 247 ha; Vila Nery com 15 ha; Vila Puresa com 26,8 ha; Vila Isabel com 17 ha; e Vila Prado com 57,7 ha (LIMA, 2007:38), como pode ser observado pelo mapa a seguir. 


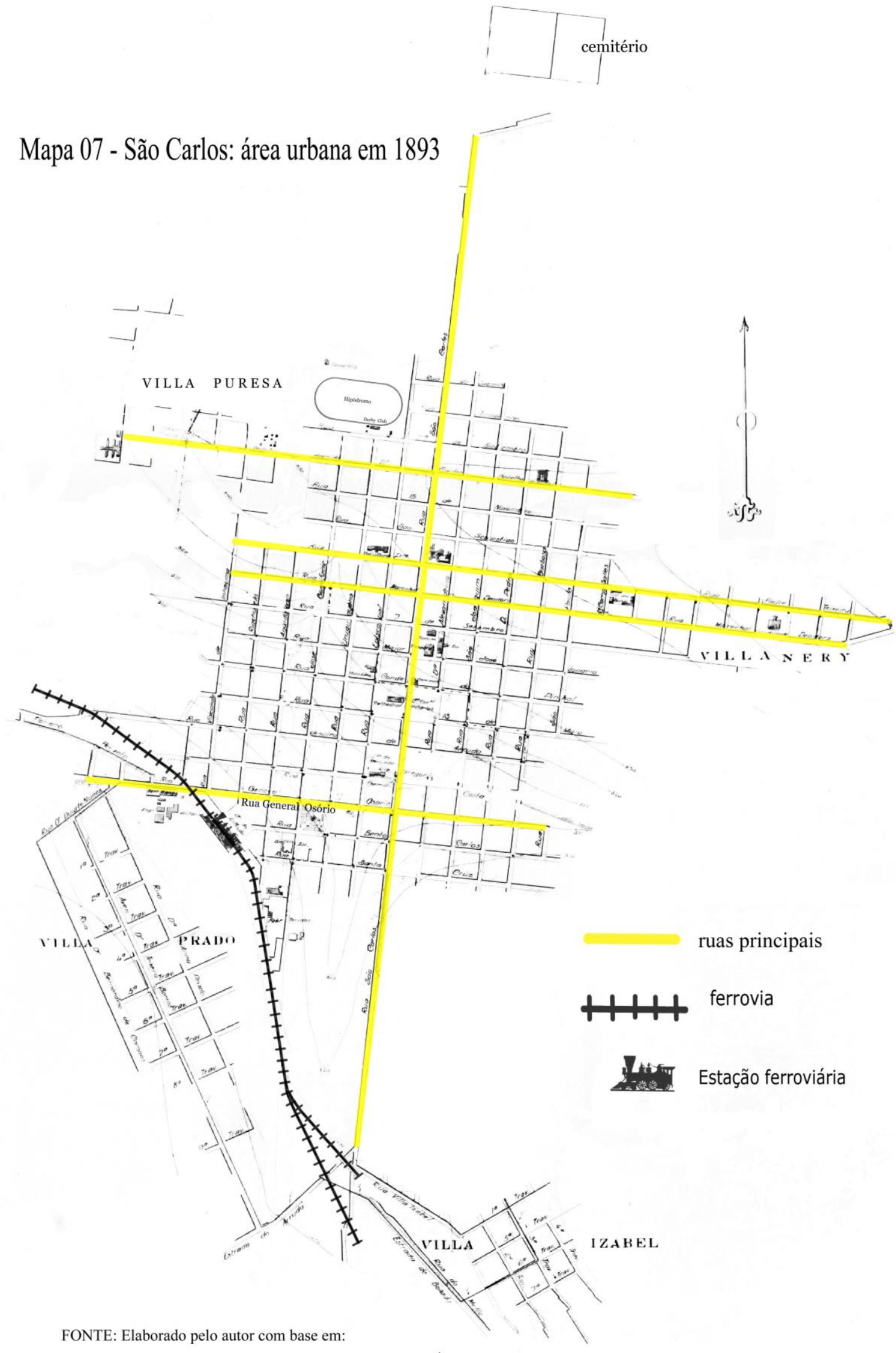

Base Cartográfica: Planta da cidade de São Carlos: Conjuncto da Rede de Água com Remanejamento e Prolongamento. Ano: 1930. Escala: 1:5.000. Autor: Joel Garcês 
Durante a fase em que ocorreu expansão da área urbana, ou seja, de 1856 até 1893, os padrões nos arruamentos realizados foram obedecidos, conferindo a homogeneidade do traçado, que é uma característica do processo de expansão desse período. Somente em 1920, seria aprovado mais um loteamento, a Vila Marcelino com 17 ha. (LIMA, 2007:53). Apesar de a área loteada permanecer praticamente a mesma até o ano de 1935, as infraestruturas urbanas, o comércio, os serviços e as pequenas indústrias continuaram se instalando.

Em 1889, foi inaugurado o serviço telefônico, de propriedade privada, sendo a proclamação da República uma das primeiras notícias transmitidas pelos aparelhos da empresa. Em 1894, a empresa de telefone foi incorporada à Companhia Telephônica S. Carlense, representada por 800 ações de cem mil réis cada, sendo que, em 1908, a Companhia modernizou e ampliou os seus serviços com a comunicação interurbana (ALMANACH 1915, 2007:39).

1890 foi o ano da contratação de engenheiros para a instalação dos serviços de água, de construção da rede de esgotos domiciliares e de iluminação por energia elétrica. Mesmo a Câmara Municipal encontrando dificuldades em fornecer melhoramentos, devido à grande baixa no câmbio, os serviços foram realizados:

“A primeira canalização d'agua, que aqui se fez, foi promovida pela Camara em 1889 e levada a effeito pela Intendencia nesse anno, utilisando-se dos serviços do industrial sr. Manoel Cabral do Santos, o qual assignou contrato com a municipalidade em 8 de Fevereiro de 1890. Possue a nossa cidade uma boa caixa d'agua e quatro chafarizes, que fornecem á uma parte da cidade a exellente agua da biquinha" (sic) (ALMANACH 1894, 2007: 75)

“A Companhia Luz Electrica de São Carlos instalou-se em novembro de 1890 com fim de dar cumprimento ao contracto celebrado em 22 de abril desse mesmo anno, entre a Intendência e os engenheiros $\mathrm{S}$. Malfatti \& Huggins" (ALMANACH 1894, 2007: 29)

Pelo contrato, obrigava-se a fazer a iluminação da cidade com 210 focos de luz durante 30 anos, recebendo em pagamento da Câmara Municipal, $12.000 \$ 000$ por ano. Durante os trabalhos para a instalação, o capital primitivo da companhia foi elevado de 
$80.000 \$ 000$ para 200.000\$000, devido ao aumento dos preços dos materiais pela baixa do câmbio. $\mathrm{O}$ engenheiro que dirigiu a obra foi o inglês dr. James Thomas Cornisk. Em 1894, a companhia possuía duas turbinas de dois dínamos, dos quais somente um era usado, e outro ficava de reserva. Buscando aumentar a iluminação particular e também fornecer energia motriz, a companhia encomendou de Londres mais uma turbina e outros aparelhos necessários para o seu funcionamento. Também mandou vir da Europa grande quantidade de lâmpadas para iluminação particular. Alguns aparelhos sofreram avarias por terem demorado muito tempo no porto de Santos, porém, já em 1894, todos os aparelhos funcionavam perfeitamente (ALMANACH 1894, 2007: 29).

A Usina Monjolinho, responsável pela produção da energia, entrou em operação em 1893. A Companhia de Luz Elétrica de São Carlos operou até 1907, quando foi substituída pela Companhia Paulista de Eletricidade (CPE). Em 1910, devido ao aumento da demanda de energia pelos bondes elétricos, que já eram planejados, a CPE construiu novas usinas, com instalações em Capão Preto, distante 20 km de São Carlos. A CPE ficou responsável pela energia de iluminação e de tração dos bondes e também pelo abastecimento dos municípios de Descalvado e Analândia (ALAMANACH, 1915, 2007:164).

O fazendeiro de café Bento Carlos de Arruda Botelho finalizou a construção do Teatro Municipal de São Carlos em 1892. O dinheiro arrecadado com o primeiro espetáculo foi aplicado em favor do projeto da construção da Santa Casa de Misericórdia (ALMANACH 1894, 2007: 25). Em 1893, foi doado um quarteirão de terreno para construir o prédio do hospital. Embora tenha servido para tratar e isolar os doentes de uma epidemia de febre amarela nos anos de 1895, 96 e 97, a Santa Casa foi oficialmente inaugurada em $1^{\circ}$ de novembro de 1899 (Almanach-Album de São Carlos 1916 - 1917, 2007).

No almanaque de São Carlos de 1894 já constavam dois bancos de propriedade de fazendeiros de café: o Banco de São Carlos e o Banco União de São Carlos, ambos localizados no largo da matriz. Havia também nesse ano, inúmeros estabelecimentos comerciais, de serviços e indústrias. Abaixo listamos os estabelecimentos comerciais e industriais: 


\begin{tabular}{|c|c|}
\hline \multicolumn{2}{|l|}{$\begin{array}{l}\text { Tabela 04: Estabelecimentos comerciais instalados em } \\
\text { São Carlos em } 1894\end{array}$} \\
\hline Estabelecimentos Comerciais & 100 \\
\hline Secos e molhados & 45 \\
\hline $\begin{array}{c}\text { Armazéns de fazendas, armarinhos, } \\
\text { chapéus, roupas feitas, etc. }\end{array}$ & 32 \\
\hline Ferragens, tintas, óleos & 17 \\
\hline Açougues & 40 \\
\hline Botequins e restaurantes & 2 \\
\hline Farmácias & $\mathbf{2 3 6}$ \\
\hline TOTAL &
\end{tabular}

Fonte: Elaborado pelo autor com base em: ALMANACH 1894, 2007

\begin{tabular}{|c|c|}
\hline \multicolumn{2}{|c|}{$\begin{array}{l}\text { Tabela 05: Estabelecimentos industriais instalado } \\
\text { em São Carlos em } 1894\end{array}$} \\
\hline Indústrias & Unidades \\
\hline Móveis & 02 \\
\hline Macarrão & 05 \\
\hline Charutos & 01 \\
\hline Sabão & 02 \\
\hline Alfaiatarias & 16 \\
\hline Cervejas e gasosas & 08 \\
\hline Fundição, ferreiros e serralheiros & 17 \\
\hline Tornearia & 01 \\
\hline Pedras para construção & 02 \\
\hline Serrarias, marcenarias e carpintarias & 23 \\
\hline Olarias & 06 \\
\hline Padarias & 10 \\
\hline Tipografias & 02 \\
\hline TOTAL & 106 \\
\hline
\end{tabular}

Fonte: Elaborado pelo autor com base em: ALMANACH 1894, 2007 
As melhorias urbanas continuaram se sucedendo, realizadas pela administração pública e por fazendeiros de café. Em 1905, o município contava com 15 escolas, totalizando aproximadamente 620 alunos. As escolas eram mantidas pelos poderes públicos municipal e estadual (FARIA, 1904). Seis anos depois, foi fundada a Escola Normal de São Carlos. Segundo Truzzi (2000:97),

\footnotetext{
"a instalação de uma Escola Normal na cidade em 1911, instituição de que poucos municípios no Estado podiam se gabar, representou a mais importante realização dos fazendeiros nesse campo."
}

O prédio da Escola Normal (figura 04) impressiona pela riqueza de materiais e acabamentos. Tal feito não poderia ser realizado sem a importação dos materiais duráveis, que resistem ao tempo. Segundo Nosella, um prédio como esse jamais poderia ser produzido em série, contradizendo o nascente industrialismo e conferindo para São Carlos um prédio único e exclusivo (NOSELLA, 2002).

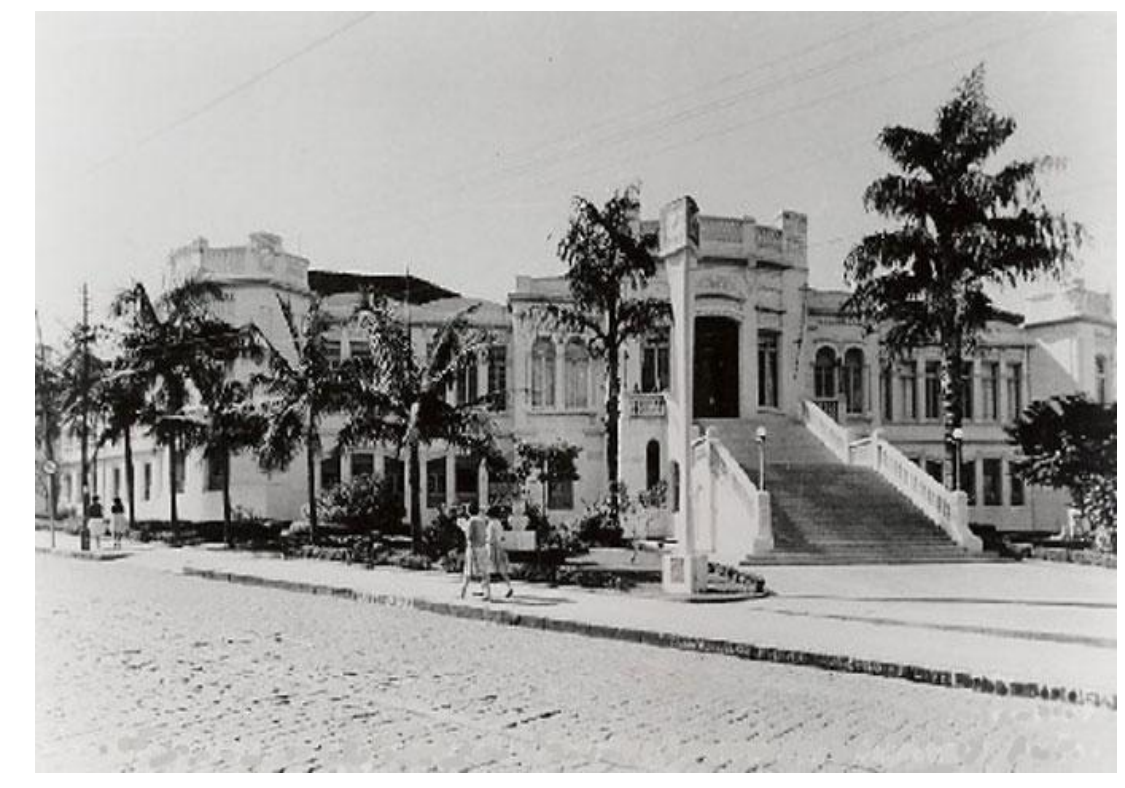

Figura 04: Escola Normal de São Carlos em 1950

Fonte: Prefeitura de São Carlos. Fundação Pró-Memória.

Em 1912, foi firmado um contrato entre a Câmara Municipal e a Companhia Paulista de Eletricidade para o estabelecimento de linhas de bondes por tração elétrica, cujo sistema de transporte público começou a funcionar em 1914 e esteve ativo até 1962. Antes do bonde, o principal meio de transporte urbano eram troles puxados por 
cavalos. Em seu trajeto, os bondes importados da Bélgica circulavam pelo centro da cidade e pelos bairros Vila Puresa e Vila Nery. Como pode ser observado na figura a seguir, o bonde possuía três linhas de circulação. A Linha 01 ligava o cemitério, na entrada norte da cidade, à estação ferroviária, passando pelas ruas São Carlos e General Osório. A Linha 02 ligava o matadouro ao ginásio do Colégio Diocesano, passando pela Santa Casa, seguindo paralelo à rua São Carlos, passando pelas ruas Bento Carlos, Santa Cruz e Pereira Lopes, até alcançar o Ginásio. A Linha 03 ligava o final da Vila Nery à estação ferroviária, passando pelas ruas Padre Teixeira, 07 de Setembro, São Carlos, 9 de Julho e Santa Cruz.

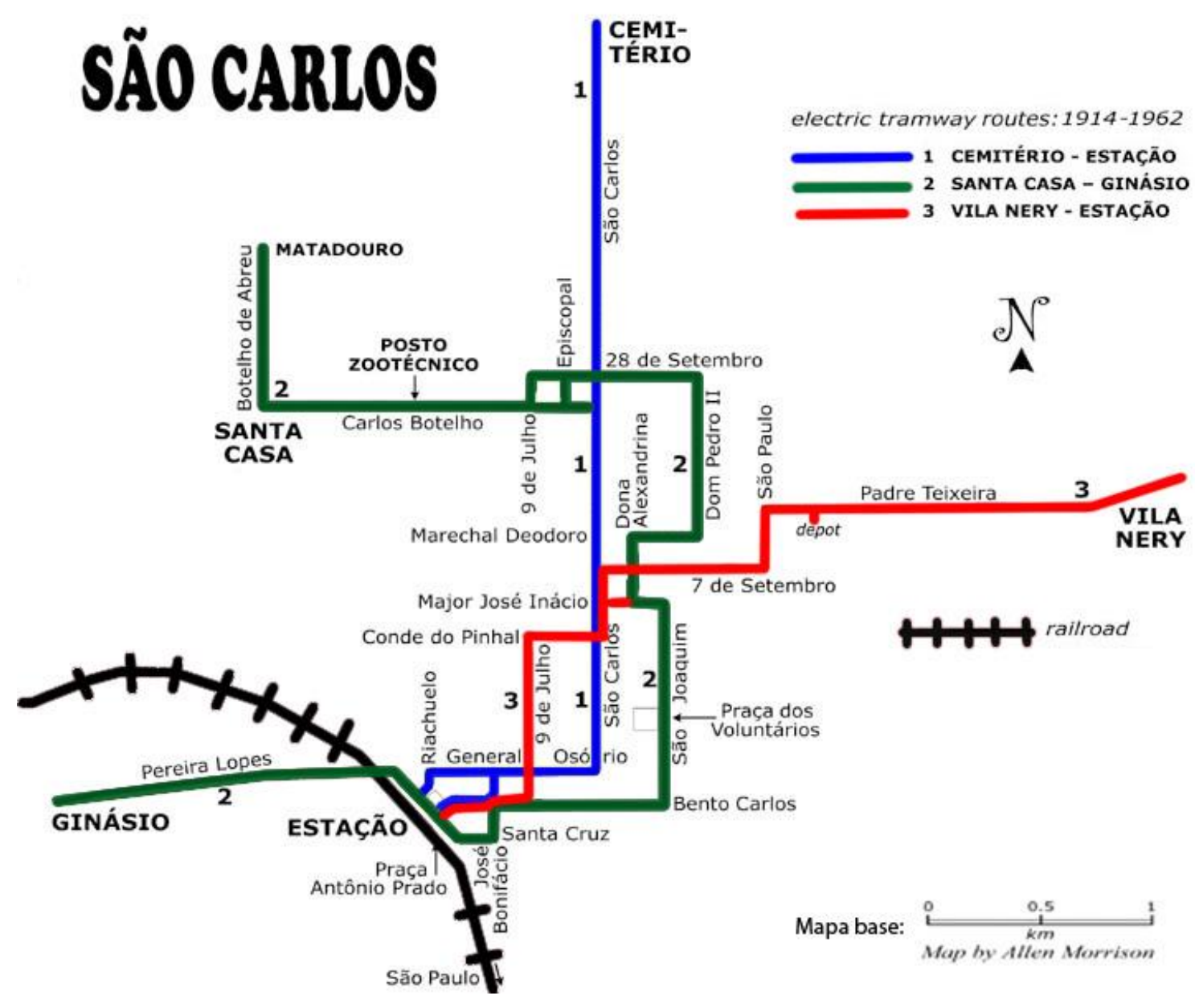

Figura 05: Infraestruturas de transporte em São Carlos até 1929

Fontes: Modificado pelo autor com base em: www.lugardotrem.com.br (mapa base) ${ }^{5}$

\footnotetext{
${ }^{5}$ Acesso em janeiro de 2015
} 
A imagem abaixo mostra o bonde elétrico em pleno funcionamento, já no ano de 1927. O bonde, apesar de ser uma importante infraestrutura de transporte, não foi determinante nos eixos de expansão, pois sua função de transporte interno limitou-se às áreas que já estavam loteadas e ocupadas, ou seja, teve sua implantação posterior à ocupação das áreas urbanas.

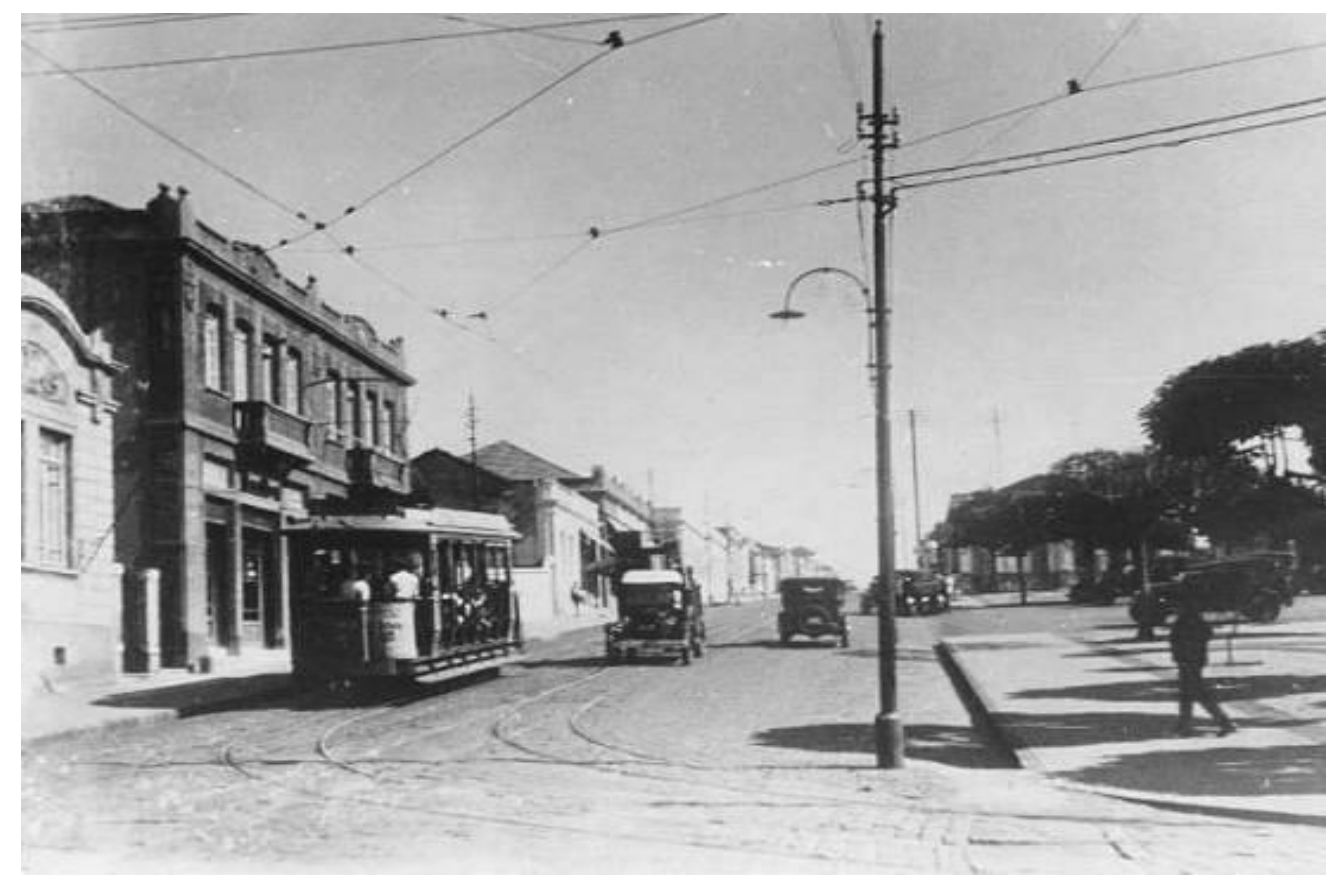

Figura 06: Bonde em São Carlos em 1927

Fonte: www.lugardotrem.com.br ${ }^{6}$

Em 1913, iniciou-se o calçamento a paralelepípedos. A ligação com a capital do estado através de estrada de rodagem se dava pela estrada São Carlos-Porto Ferreira. Neste último ponto, se juntava com a estrada estadual São Paulo-Ribeirão Preto, a qual foi iniciada a construção em 1920 por Washington Luís e que, posteriormente, seria denominada Rodovia Anhanguera. Em 1928, um anúncio do almanaque de São Carlos (ALAMANACK ANNUARIO DE S. CARLOS 1928, 2007) destacava as seguintes estradas:

"São as seguintes as distancias em optimas estradas de rodagem especiaes para automóveis, da cidade de S. Carlos á divisa de:

\footnotetext{
${ }^{6}$ Acesso em janeiro de 2015
} 


$\begin{array}{ll}\text { Araraquara } & 25 \mathrm{kls} \\ \text { Brotas } & 23 \mathrm{kls} \\ \text { Ribeirão Bonito } & 33 \mathrm{kls} \\ \text { Santa Eudóxia } & 39 \mathrm{kls} \\ \text { Ibaté } & 14 \mathrm{kls} \\ \text { Babylonia } & 12,25 \mathrm{kls} "(\mathrm{sic})\end{array}$

Em 1927 estavam registrados na Repartição de veículos da Câmara Municipal, 553 veículos de tração a gasolina, 445 trolys e 1044 carroças (ALAMANACK ANNUARIO DE S. CARLOS 1928, 2007). Pela imagem acima se vê os carros circulando e dividindo espaço com o bonde.

Embora a elite agrária tenha sido responsável pela implantação de infraestruturas, no tocante às indústrias, a aplicação do capital cafeeiro foi feita indiretamente através dos bancos e, diretamente, no beneficiamento do café e nas indústrias têxteis de fabricação de sacaria para o café, o que demonstra apenas tentativas de aumento do lucro agrícola e não empreendedorismo industrial (GRIMBERG, 2009).

Enquanto começavam a surgir pequenos estabelecimentos industriais em São Carlos, era natural que os cafeicultores não se inserissem nesse ramo, pois o café ainda provia grande fortuna e os estabelecimentos industriais ainda eram simples e pequenos. Conforme relatado por Truzzi (2000:82), a produção de café em São Carlos cresceu atingindo seu auge no ano de 1906, com mais de 2 milhões de arrobas, flutuando pouco na casa de 1 milhão de arrobas até 1917; após esse ano, começa a decair, mantendo-se na média de 800 mil arrobas até o final da década de 20, com exceção do ano de 1929, quando atinge 1.160 .000 arrobas; $\operatorname{logo}$ em seguida, decai novamente, então vertiginosamente de forma que não mais se recuperar. Porém, o montante produzido não necessariamente corresponde ao lucro obtido, devido às políticas de valorização do café para tentar contornar as intermitentes crises.

Em 1882, já tinha se formado a primeira associação de italianos em São Carlos, composta de fazendeiros, industriais e comerciantes. Com a abolição do sistema escravista, alguns imigrantes desenvolveram atividades econômicas urbanas capitalistas, inserindo-se no setor comercial e introduzindo unidades industriais. Truzzi (2000) mostra como os imigrantes, sobretudo italianos, foram os pioneiros na instalação das fábricas e que, posteriormente, conquistaram status na sociedade, tendo importante papel político. Grimberg (2009) aponta que a aplicação do pequeno capital proveniente 
do imigrante foi preponderante nas indústrias durante os anos de 1900 até 1920. Ao final da década de 1920, as indústrias instaladas por imigrantes em São Carlos fabricavam diversos produtos, entre os quais se destacam tecidos, roupas, sapatos, bolachas, cola, pregos, peneiras, sabão, cadeiras, gelo, salames, licores, biscoitos, cerveja e bebidas sem álcool, flores artificiais, toucas, macarrão, produtos pirotécnicos e oficinas mecânicas (ALAMANACK ANNUARIO DE S. CARLOS 1928, 2007).

A Fábrica de Tecidos S. Magdalena, (que depois passou a se chamar Cia. Fiação de Tecidos de Algodão) foi fundada em 1916 e já empregava 500 pessoas em 1917. Nesse ano, era o maior estabelecimento industrial do município. Foi fundada por imigrantes italiano e suíço e localizava-se próximo à estação ferroviária. Essa indústria cresceu muito e em 1936 continuava a ser o maior estabelecimento, empregando 1090 trabalhadores (Correio de São Carlos, São Carlos, 13 de janeiro de 1938). No mesmo ano de 1916 foi fundada por imigrantes da região da Toscana, a indústria de artigos de ferro e madeira S/A Miguel Giometti, que se tornou grande fornecedora de ferramentas para a agricultura. Em 1925, foi fundada a fábrica de lápis H. Fehr Ltda., por um grupo de imigrantes residentes em São Carlos, com capital exclusivamente local. Posteriormente, foi comprada pela Lápis Johan Faber (DEVESCOVI, 1987).

Os imigrantes também tiveram participação no capital financeiro. Truzzi (2000:150) aponta que, em 1915, o imigrante italiano Giovani Apprati era proprietário do Banco de Crédito Internacional, com sede em São Carlos e uma agência em Araraquara. Abaixo, um anúncio de 1915 veicula a propaganda desse banco e de um estabelecimento comercial típico desse período, i.e, praticando importação e venda dos mais variados produtos. 


\section{Banco de Credito Internacional}

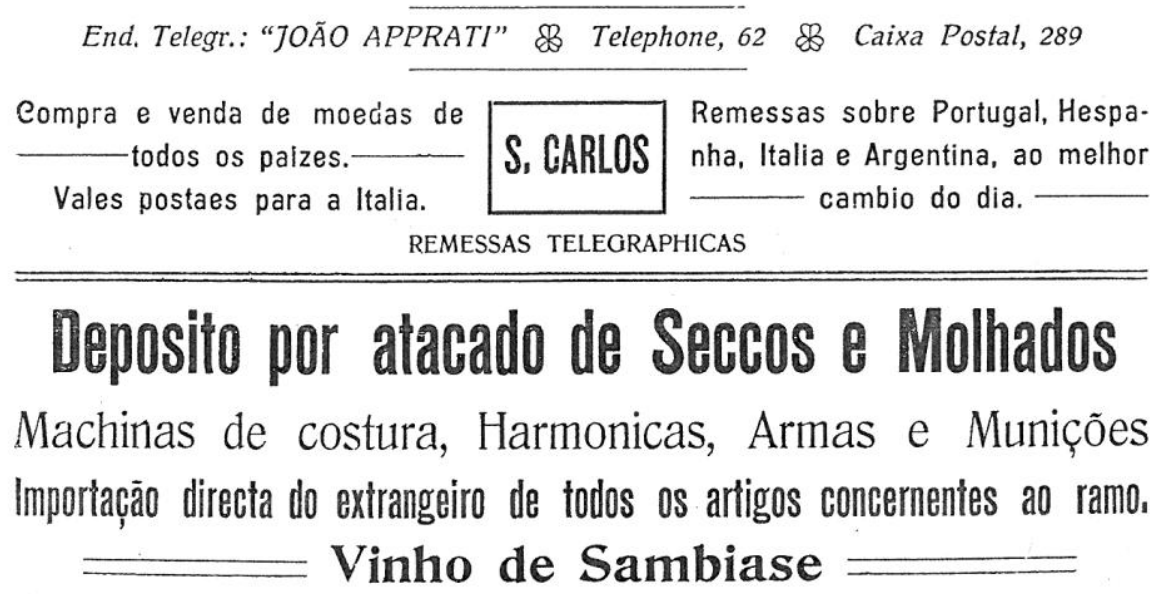

Figura 07: Banco de crédito internacional e depósito de secos e molhados em 1915.

Fonte: ALMANACH DE S. CARLOS PARA 1915. (Ed. Fac-sím.) Joaquim Augusto (Ed.). São Carlos, Sp: EdUFSCar, 2007.

A tabela abaixo mostra as indústrias que foram fundadas em São Carlos antes de 1930 e que ainda funcionavam no ano de 1940. De um total de 146, apenas 31 delas sobreviveram no mercado até 1940.

\begin{tabular}{|l|l|l|l|}
\hline \multicolumn{4}{|l|}{ Tabela 06: Indústrias Instaladas em São Carlos em 1940 com fundação anterior a 1930.} \\
\hline PROPRIETÁRIO/EMPRESA & ENDEREÇO & RAMO & DATA \\
\hline $\begin{array}{l}\text { Manoel Sanches/ Marmoraria } \\
\text { Sancarlense }\end{array}$ & R. São Carlos, 306 & Artefatos de Mármore & 1901 \\
\hline $\begin{array}{l}\text { José Albregard/ Colchoaria } \\
\text { Francêza }\end{array}$ & R. 9 de Julho, 51 & Fab. de Colchões & 1904 \\
\hline Nicola Focchini & R. 28 de setembro, 54 & Fab. de Bebidas & 1906 \\
\hline Vicente Gallucci/ Casas Gallucci & R. Episcopal, 53 & Fab. de Calçados & 1907 \\
\hline José Dolosic/ Ferraria Dolosic & R. São Carlos, 493 & Of. de Ferreiro & 1914 \\
\hline João Stefanutti/ Fab. Sta. Maria & R. São Joaquim, 62 & Fab. de Cadeiras & 1915 \\
\hline $\begin{array}{l}\text { Cia. Fiação de Tecidos de Algodão } \\
\text { R. Aquidaban, 2 }\end{array}$ & $\begin{array}{l}\text { Fab. de Tecidos de } \\
\text { Algodão }\end{array}$ & 1916 \\
\hline F. Thomaz Crncovid \& Irmão & Estrada Matadouro & Of. de Seleiro & 1916 \\
\hline $\begin{array}{l}\text { Mario Constanzo/ Alfaiataria } \\
\text { Constanzo }\end{array}$ & R. Bento Carlos, 16 & Alfaiataria & 1918 \\
\hline $\begin{array}{l}\text { Germano Fehr/ Fab. Móveis G. } \\
\text { Fehr }\end{array}$ & R. Episcopal, 65 a 67 & Fab. de Móveis & 1920 \\
\hline Antonio Basso/ Serraria Usonia & $\begin{array}{l}\text { R. Visconde de Inhaúma, } \\
43\end{array}$ & Serraria & 1921 \\
\hline Miguel Petroni/ Alfaiataria Petroni & R. 9 de Julho, 88 & Alfaiataria & 1921 \\
\hline V. Mastrofrancisco \& Filhos/ Of. & R. São Carlos, 214 & Of. Serralheria & 1922 \\
\hline
\end{tabular}




\begin{tabular}{|l|l|l|l|}
\hline Mastrofrancisco & & & \\
\hline $\begin{array}{l}\text { Eugenio Gallucci/ Alfaiataria } \\
\text { Gallucci }\end{array}$ & R. General Osório, 171 & Alfaiataria & 1922 \\
\hline Luiz Cascaldi \& José Storino & S. Carlos & Of. de Cantaria & 1923 \\
\hline Irmãos Dinuci & $\begin{array}{l}\text { R. Major José Ignácio, } \\
106\end{array}$ & Alfaiataria & 1923 \\
\hline João Moccio/ Alfaiatria Storino & $\begin{array}{l}\text { R. Marechal Deodoro, } \\
113\end{array}$ & Alfaiataria & 1923 \\
\hline $\begin{array}{l}\text { João Coelho de Faria/ Cerâmica S. } \\
\text { Carlos }\end{array}$ & R. José Bonifácio, 65 & Cerâmica & 1923 \\
\hline Mana \& Filhos/ A Gráfica & R. Marechal Deodoro, 77 & Tipografia & 1923 \\
\hline $\begin{array}{l}\text { Núncio Cardinali/ Grande Of. } \\
\text { Mecânica }\end{array}$ & R. São Carlos, 110 & Of. Mecânica & 1924 \\
\hline $\begin{array}{l}\text { Probo Lombardi/ Carpintaria } \\
\text { Centenário }\end{array}$ & R. São Carlos, 140 & Carpintaria & 1925 \\
\hline $\begin{array}{l}\text { Antonio Martinez Carrera \& Filho// } \\
\text { Fab. de Móveis Carrera }\end{array}$ & R. Geminiano Costa, 31 & Fab. de Móveis & 1925 \\
\hline Gelsomino Saia & R. 13 de Maio, 55 & Fab. de Móveis & 1925 \\
\hline $\begin{array}{l}\text { Fernandes \& Batista/ Alfaiataria } \\
\text { Artística }\end{array}$ & R. General Osório, 241 & Alfaiataria & 1927 \\
\hline Jose Natal & R. José Bonifácio, 73 & Of. de Seleiro & 1928 \\
\hline $\begin{array}{l}\text { Carlos Facchina/ Estab. Comercial } \\
\text { S. Carlos }\end{array}$ & R. Bento Carlos & Fab. de Adubos & 1928 \\
\hline José Masci & R. General Osório, 77 & Of. Mecânica & 1928 \\
\hline Antonio Saltão & R. General Osório, 166 & Fab. de Calçados & 1928 \\
\hline E. Júlio Rocha \& Cia. & Estrada de Retiro & Curtume & 1929 \\
\hline Guelfi \& Dotto/ A Sancarlense & R. General Osório, 172 & Fab. de Balas & 1929 \\
\hline M. Vaccari \& Filhos & Bairro Vila Nery & Fab. de Fogos & 1929 \\
\hline & & & \\
\hline
\end{tabular}

Fonte: Elaborado pelo autor com base em: Catálogo das Indústrias do Estado de São Paulo (exclusive para o município da capital). São Paulo: DEE. 1943.

\section{2 - Crescimento industrial em São Carlos: décadas de 1930 e 1940}

A compreensão do crescimento industrial nas décadas de 1930 e 1940 é uma especificidade dos países de industrialização tardia, que começaram com produção de bens de consumo não duráveis, denominada industrialização restringida. Com a paulatina substituição de importação, o mercado interno foi crescendo e a burguesia acumulando, até que foram criadas as condições para o desenvolvimento da industrialização propriamente dita, quando se instalaram os segmentos de bens de produção, bens de capital e de consumo duráveis, a partir da década de 1950, acelerando o ritmo de crescimento do mercado interno e da urbanização. Quanto a esta última, contabilizando todo o território nacional, foi a partir do início da década de 1970 que a população urbana ultrapassou a rural. Em São Carlos, no entanto, esse fato ocorre a partir do ano 1940 (IBGE. Censo Demográfico de 1940). 
Mostraremos como a indústria em São Carlos se inseria no contexto nacional durante as décadas de 1930 e 1940. Vale lembrar que, no período que se estende do final do século XIX até 1929, a indústria são-carlense já atendia a demanda do complexo cafeeiro, com as fábricas simples. Devido ao desenvolvimento desse complexo cafeeiro, a cidade havia reunido as condições que possibilitaram a reorientação da atividade produtiva, ou seja, infraestrutura urbana, sistema bancário, acumulação do pequeno capital industrial, disponibilidade de mão de obra e mercado consumidor interno.

Durante a década de 1930, se intensificou o crescimento industrial, e o processo de acumulação assumiu outra lógica, isto é, de substituição de importação, sobretudo de bens de consumo, produzidos por uma massa de trabalhadores recém saída do campo.

Em relação às indústrias das cidades próximas, São Carlos apresenta algumas especificidades. Embora região do oeste paulista tenha se caracterizado por um processo de industrialização que se articulou com a agricultura e a pecuária, em São Carlos o ramo de alimentos se desenvolveu pouco, caracterizando-se principalmente por pequenos estabelecimentos voltados para o mercado local, como padarias e fábricas de doces, massas e bebidas (LORENZO, 1979).

Mesmo com a crise da cafeicultura iniciada em 1929, o município não diversificou os gêneros de sua produção agrícola devido a dois fatores principais: a rigidez da estrutura da propriedade agrária, em comparação às cidades vizinhas e a baixa fertilidade da maioria dos solos locais. Segundo Bjornberg (apud DEVESCOVI, 1987:23), 61,6\% da área do município correspondem ao solo de tipo arenoso e de baixa coesão, enquanto que as manchas de Terra Rocha correspondem a 31,6\%. Em relação à propriedade da terra, as tabelas mostram as diferenças entre São Carlos, Araraquara e Rio Claro.

A tabela 07 mostra que o município de São Carlos possuía a maior população urbana relativamente ao total da população, quando comparado aos municípios de Araraquara, Rio Claro e Jaú. Em relação à produção agrícola, São Carlos não se destacou em nenhum produto. Jaú, por exemplo, mesmo possuindo menos da metade da área de São Carlos e Rio Claro, era o maior produtor de café e mamona e, em relação ao valor da produção, superou os dois municípios. Rio Claro era o maior produtor de arroz, milho e laranja. No município de Araraquara a produção foi bastante diversificada e em maior quantidade, superando em mais de três vezes o valor da 
produção de São Carlos, com destaque para a produção de algodão, café e feijão. Entre os quatro municípios, São Carlos possuía a menor produção agrícola.

Com relação ao tamanho das propriedades, podemos observar na tabela 08 que entre as pequenas propriedades de até 50 alqueires, São Carlos possuía 183, enquanto Araraquara possuía 736 e Rio Claro, 625. Em relação às grandes fazendas de 500 e 1.000 alqueires, São Carlos contava com 20, Araraquara com 7 e Rio Claro apenas 2. Entre as propriedades com mais de 1.000 alqueires, São Carlos possuía 7, Araraquara 6 e Rio Claro 2. Portanto, fica evidente a baixa produtividade agrícola e a elevada concentração da propriedade da terra em São Carlos em relação aos municípios vizinhos.

Esses fatores ligados à produção agrícola influenciaram o desenvolvimento das indústrias nesses municípios. Ao analisar o crescimento industrial na região de Araraquara-São Carlos, Lorenzo (1979:90) mostra essa influência, ao apontar que em São Carlos se desenvolveram indústrias têxteis, de móveis e de metalurgia, enquanto que em Araraquara as principais atividades industriais eram as açucareiras, de processamento e refino de óleos vegetais, de leite e derivados e de frutas cítricas.

\begin{tabular}{|c|c|c|c|c|}
\hline \multicolumn{5}{|c|}{$\begin{array}{l}\text { Tabela 07: Área, população e produção agrícola em São Carlos, Araraquara, } \\
\text { Rio Claro e Jaú - } 1938\end{array}$} \\
\hline & São Carlos & Araraquara & Rio Claro & Jaú \\
\hline Área & $1.258 \mathrm{~km}^{2}$ & $2.085 \mathrm{~km}^{2}$ & $1.470 \mathrm{~km}^{2}$ & $525 \mathrm{~km}^{2}$ \\
\hline População total & 51.800 & 67.000 & 55.800 & 53.800 \\
\hline População urbana & 20.800 & 23.500 & 19.600 & 18.000 \\
\hline \multicolumn{5}{|l|}{ Produção: } \\
\hline Café (arrobas) & 460.000 & 840.000 & 160.000 & 880.000 \\
\hline Arroz (sc.) & 4.000 & 32.000 & 42.000 & 13.000 \\
\hline Feijão (sc.) & 9.000 & 71.500 & 9.000 & 12.00 \\
\hline Milho (sc.) & 40.000 & 100.000 & 180.000 & 165.000 \\
\hline Mamona (kg) & 32.000 & --- & --- & 205.000 \\
\hline Algodão (ar.) & 120.000 & 600.000 & 150.000 & 82.000 \\
\hline Laranja (cx.) & 79.000 & 100.000 & 150.000 & 15.000 \\
\hline Banana (cachos) & 130.000 & 200.000 & 50.000 & 80.000 \\
\hline Abacaxi (un.) & 1.700 .000 & 1.800 .000 & 80.000 & 70.000 \\
\hline $\begin{array}{l}\text { Valor da prod. } \\
\text { agrícola }(\$)\end{array}$ & 13.500 .000 & 46.600 .000 & 14.000 .000 & 20.000 .000 \\
\hline
\end{tabular}


Fonte: Elaborado pelo autor com base em: Jornal Correio de São Carlos, 27 de fevereiro de 1938.

\begin{tabular}{|c|c|c|c|}
\hline Alqueires & São Carlos & Araraquara & Rio Claro \\
\hline Até 50 & 115 & 584 & 844 \\
\hline $10-25$ & 111 & 555 & 432 \\
\hline $25-50$ & 72 & 181 & 223 \\
\hline $50-100$ & 71 & 99 & 105 \\
\hline $100-250$ & 55 & 64 & 52 \\
\hline $250-500$ & 30 & 64 & 15 \\
\hline $500-1.000$ & 20 & 07 & 02 \\
\hline Mais de 1.000 & 07 & 06 & 02 \\
\hline
\end{tabular}

Fonte: Lavoura de São Paulo. Publicação Anual de Estatística Geral e Agrícola dos Municípios do Estado, São Paulo, Sociedade Impressora Paulista, 1937, apud Truzzi, 2000:103.

Os dados sobre indústrias mostrados no quadro 01 e nas tabelas 09 e 10, permitem observar que, entre 1930 e 1948, houve crescimento no número de estabelecimentos industriais em São Carlos, porém, em relação à representatividade dos ramos industriais no total da produção industrial houve pouca mudança. Os ramos de vestuário, alimentação eram os que tinham maior número de estabelecimentos, nesta ordem. Destaque para o crescimento do ramo mobiliário (Quadro 01). Segundo Truzzi (2000:133) a indústria moveleira se desenvolveu bastante no município de São Carlos, aproveitando-se da oferta de matéria-prima proveniente das serrarias locais, tornando-se um centro moveleiro de reconhecida importância no cenário paulista. No final da década de 1930, São Carlos passou pela chamada "febre das camas", sendo que todas as indústrias produziam o mesmo modelo, chamado 'Cama Patente'. 


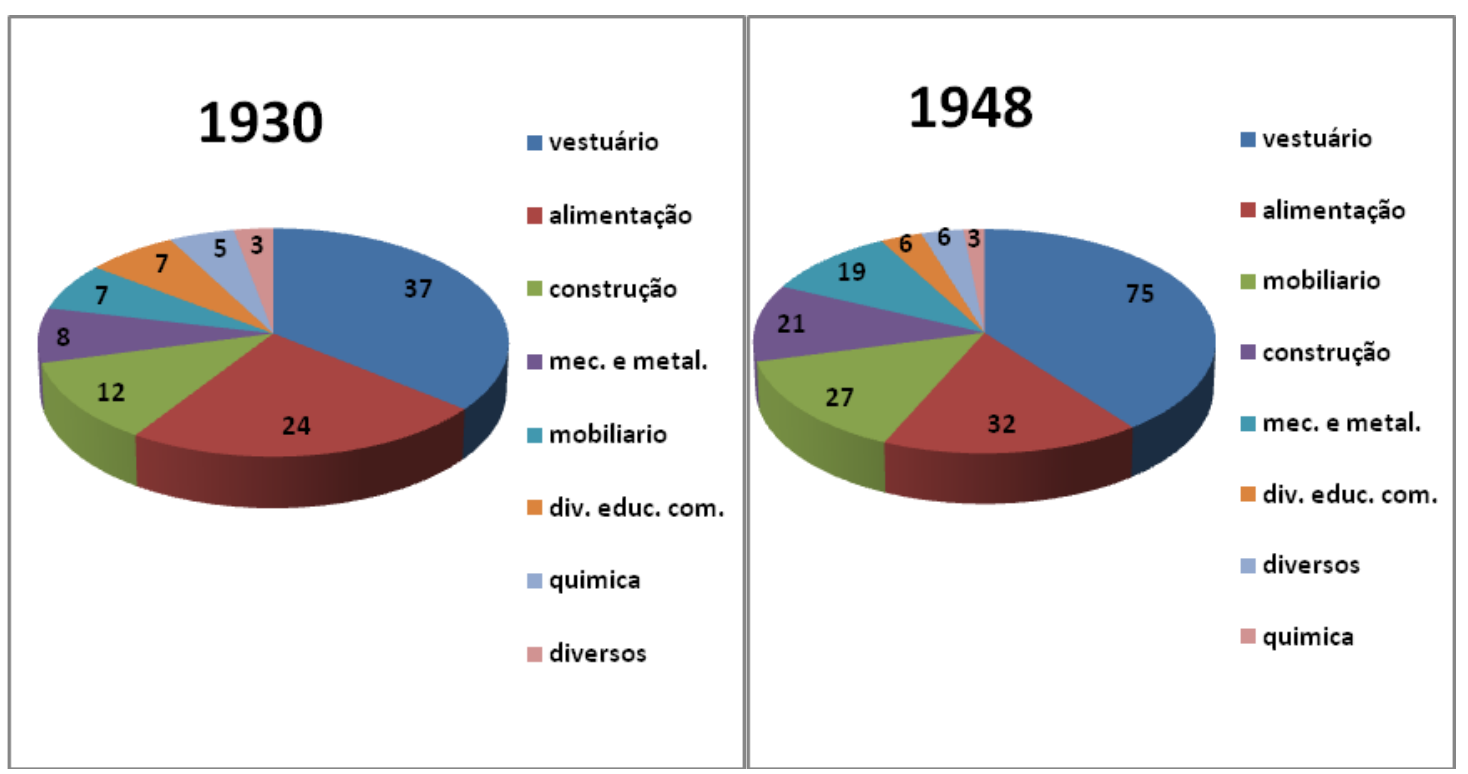

Quadro 01 - São Carlos: número de estabelecimentos industriais por ramos*: 1930 e 1948

* Vestuário: inclui confecções de roupas e calçados e produtos para indústria do vestuário (tecidos e couros); Metal-Mecânica: inclui refrigeradores elétricos; Diversão, Educação e Comunicação: inclui lápis, carimbos, brinquedos, artigos para esporte, gráfica, tipografia, pastas de couro, porta notas e semelhantes; Diversos: inclui estofados para veículos, caixões mortuários, artigos de borracha, de selaria, de lentes, de ourivesaria e de toucador.

Fontes: Elaborado pelo autor com base em: PREFEITURA MUNICIPAL DE SÃO CARLOS. Livro de impostos sobre indústrias e profissões para os anos de 1930 e 1948. São Carlos: Fundação Pró-Memória de São Carlos

O número total de indústrias instaladas aumentou 39\% ao logo das décadas de 1930 e 1940, passando de 103 para 142 novos estabelecimentos. Os ramos que mais cresceram foram o de mobiliário (157\%) e metal-mecânica (137\%), cada um com 11 novos estabelecimentos. É notório que o ramo de Construção cresceu apenas 8\%, o que se explica pela pequena expansão urbana nessa década. Já ao longo da década de 1940, o número total de indústrias cresceu $33 \%$, sendo que os ramos que mais cresceram foram o de construção (61\%), de vestuário (56\%) e mobiliário (50\%) [Tabela 09]. 


\begin{tabular}{|l|c|c|c|c|c|c|}
\hline \multicolumn{3}{|c|}{$\begin{array}{l}\text { Tabela 09: Indústrias instaladas por ramos industriais* em São Carlos - 1930, } \\
1940 \text { e } 1948\end{array}$} & \multicolumn{3}{c|}{ CRESCIMENTO } \\
\hline \multirow{2}{*}{$\begin{array}{l}\text { RAMOS } \\
\text { INDUSTRIAIS }\end{array}$} & $\begin{array}{c}1930 \\
\left(\mathrm{~N}^{\circ}\right)\end{array}$ & $\begin{array}{c}1940 \\
\left(\mathrm{~N}^{\circ}\right)\end{array}$ & $\begin{array}{c}1948 \\
\left(\mathrm{~N}^{\circ}\right)\end{array}$ & $1930-1940$ & $1940-1948$ & $\mathbf{1 9 3 0 - 1 9 4 8}$ \\
\hline Mobiliário & 07 & 18 & 27 & $157 \%$ & $50 \%$ & $\mathbf{2 8 7 \%}$ \\
\hline Metal-Mecânica & 08 & 19 & 19 & $137 \%$ & --- & $\mathbf{1 3 7 \%}$ \\
\hline Vestuário & 37 & 48 & 75 & $30 \%$ & $56 \%$ & $\mathbf{1 0 2 \%}$ \\
\hline Diversos & 03 & 07 & 06 & $166 \%$ & $-14 \%$ & $\mathbf{1 0 0 \%}$ \\
\hline Construção & 12 & 13 & 21 & $8 \%$ & $61 \%$ & $\mathbf{7 5 \%}$ \\
\hline Alimentação & 24 & 26 & 32 & $8 \%$ & $23 \%$ & $\mathbf{3 3 \%}$ \\
\hline $\begin{array}{l}\text { Diversão, educ. e } \\
\text { comunicação }\end{array}$ & 07 & 09 & 06 & $50 \%$ & $-33 \%$ & $\mathbf{- 1 \%}$ \\
\hline Química & 05 & 02 & 03 & $-60 \%$ & $50 \%$ & $\mathbf{- 4 0 \%}$ \\
\hline TOTAL & $\mathbf{1 0 3}$ & $\mathbf{1 4 2}$ & $\mathbf{1 8 9}$ & $\mathbf{3 9 \%}$ & $\mathbf{3 3 \%}$ & $\mathbf{8 6 \%}$ \\
\hline
\end{tabular}

* Ver nota p. 75

Fontes: Elaborado pelo autor com base em: PREFEITURA MUNICIPAL DE SÃO CARLOS. Livro de impostos sobre indústrias e profissões para os anos de 1930 e 1948. São Carlos: Fundação Pró-Memória de São Carlos; CATÁlOGO das Indústrias do Estado de São Paulo (exclusive para o município da capital). São Paulo: DEE. 1943.

Considerando as duas décadas, o crescimento do número de indústrias foi de $86 \%$, passando de 103 para 189 estabelecimentos. Verificamos que houve um desenvolvimento muito significativo em alguns ramos. O de mobiliário cresceu $287 \%$ (19 indústrias), o de metal-mecânica 137\% (11 novas indústrias), o de vestuário 102\% (38 indústrias). Os dados mostram que houve maior crescimento nestes ramos citados, contudo, os ramos de Vestuário e Alimentação se mantiveram com o maior número de estabelecimentos, com 75 e 32 unidades, respectivamente.

Entre as indústrias instaladas em 1948, 13,3\% dos estabelecimentos foram fundados até 1930 e 13,9\% foram fundadas entre 1931 e 1940. Portanto, 72,8\% das indústrias em funcionamento no ano de 1948 foram fundadas após 1941, indicando, além de um crescimento no número de estabelecimentos, uma renovação do parque 
industrial local (PREFEITURA MUNICIPAL DE SÃO CARLOS. Livro de impostos sobre indústrias e profissões para os anos de 1930 e 1948. São Carlos: Fundação PróMemória de São Carlos; CATÁLOGO das Indústrias do Estado de São Paulo [exclusive para o município da capital]. São Paulo: DEE. 1943).

A tabela 10 mostra o montante de imposto municipal pago por ramos industriais nos anos de 1930 e $1948^{7}$, o que permite verificar a evolução dos ramos no total de impostos pagos para a prefeitura, pois é evidente que somente o número de estabelecimentos não mede a sua importância para a economia. Isso se faz necessário pois, embora tenha ocorrido um maior crescimento no número de estabelecimentos nos ramos de mobiliário e de metal-mecânica, em relação aos impostos, o ramo do vestuário teve maior crescimento, tornando-se ainda mais representativo. Vale salientar que, apesar do baixo crescimento do número de estabelecimentos e da diminuição da parcela de impostos para o total da receita (de 21,4\% em 1930 para 16\% em 1948), o ramo de alimentação se manteve como o segundo ramo de indústria que mais contribuiu em impostos para a Prefeitura. O ramo de construção, apesar de crescer $75 \%$ em número de estabelecimentos, diminuiu sua parcela relativa ao total de impostos, passando de $19,7 \%$ em 1930 para 7,5\% em 1948. O expressivo crescimento do ramo de produtos para diversão, educação e comunicação deve-se à instalação da indústria de Lápis Johann Faber Ltda., entre 1930 e 1948.

\footnotetext{
${ }^{7}$ Em entrevista concedida em 22/10/2014. Mario Mafei (ex-prefeito de São Carlos e proprietário da empresa S/A Miguel Giometti, fundada em 1916 e ainda hoje em funcionamento no mesmo endereço), relata que a maior parte do Imposto sobre Indústrias da Prefeitura de São Carlos incidia sobre o faturamento das indústrias, podendo incluir algumas taxas, como letreiros de propaganda, p. ex..
} 


\begin{tabular}{|c|c|c|c|c|c|}
\hline $\begin{array}{c}\text { RAMOS } \\
\text { INDUSTRIAIS }\end{array}$ & $\begin{array}{c}1930 \\
\text { (em Mil Réis) }\end{array}$ & $\begin{array}{l}\% \text { DO } \\
\text { TOTAL }\end{array}$ & $\begin{array}{c}1948 \\
\text { (em Crs.) }\end{array}$ & $\begin{array}{l}\% \text { DO } \\
\text { TOTAL }\end{array}$ & $\begin{array}{c}\text { CRESCIMENTO } \\
1930-1948(\%)\end{array}$ \\
\hline Vestuário & 6.059 & 23,1 & 116.099 & 36,6 & 13,5 \\
\hline Mobiliário & 1.110 & 4,2 & 44.996 & 14,2 & 10 \\
\hline $\begin{array}{c}\text { Diversão, educ. e } \\
\text { comun. }\end{array}$ & 2.240 & 8,5 & 14.740 & 4,6 & 7,5 \\
\hline Química & 1.982 & 7,5 & 12.490 & 3,9 & 4,2 \\
\hline Metal-Mecânica & 3.379 & 12,9 & 49.770 & 15,7 & 2,8 \\
\hline Diversos & 618 & 2,3 & 4.490 & 1,4 & 2,3 \\
\hline Alimentação & 5.614 & 21,4 & 50.874 & 16 & $-5,5$ \\
\hline Construção & 5.160 & 19,7 & 23.060 & 7,2 & $-12,5$ \\
\hline TOTAL & 26.162 & 100 & 316.519 & 100 & --- \\
\hline
\end{tabular}

\section{* Ver nota p.75}

Fonte: Elaborado pelo autor com base em: PREFEITURA MUNICIPAL DE SÃO CARLOS. Livro de impostos sobre indústrias e profissões para os anos de 1930 e 1948. São Carlos: Fundação Pró-Memória de São Carlos.

Considerando o número de estabelecimentos e os impostos pagos, podemos afirmar sobre a indústria em São Carlos no período de 1930 a 1948, que seu crescimento foi voltado para o mercado interno e que os ramos que mais se desenvolveram foram os de vestuário, metal-mecânica e mobiliário.

Em 1930, São Carlos contava com 27 alfaiatarias. Segundo artigo publicado no jornal Correio de São Carlos, a Fábrica de Tecidos S. Magdalena, (que depois passou a se chamar Cia. Fiação de Tecidos de Algodão, popularmente conhecida como “Tecidão”) foi fundada em São Carlos no ano de 1915, próxima à estação ferroviária. Em 1936, empregava 1090 trabalhadores e atendia outros estados:

"Durante o mesmo anno de 1936 exportou 2.385.305 metros de tecidos sendo que os principaes mercados foram São Paulo (698.100 metros), Rio de Janeiro (870.614 metros) e Rio Grande do Sul (228.214 metros). Anexas a este gênero fabril funcionam ainda as seguintes indústrias: extração de óleo de caroço de algodão e mamona 
e fábrica de artefatos de alumínio (sic)" (Correio de São Carlos, 13 de janeiro de 1938).

O crescimento do ramo vestuário ocorreu principalmente na década de 1940, quando mais que dobrou o número de estabelecimentos e a quantidade de impostos sobre faturamento pago para a Prefeitura. No ano de 1940 foi criada a ABASC (Associação Beneficente dos Alfaiates de São Carlos), que defendia os direitos da categoria, promovia bailes, shows de artistas populares e congressos. São Carlos chegou a sediar três congressos nacionais de alfaiataria: em 1944, reuniu 1.500 pessoas; em 1948, 3.200 pessoas; e em 1957, mais de 5 mil pessoas. Nas décadas de 1940 e 1950, a cidade ficou conhecida como a capital da alfaiataria, atendendo todo o mercado nacional, desde uniformes para as indústrias Matarazzo e Companhia de Estrada de Ferro, até ternos para políticos ${ }^{8}$. Algo que também favoreceu o setor de vestuário foi a criação na Escola Industrial Paulino Botelho (fundada em 1932), de um curso de Alfaiataria e um curso de Fiação e Tecelagem, que impulsionavam ainda mais o setor de vestuário na cidade (LEI N. 373, DE 25 DE JULHO DE 1949).

A indústria têxtil foi beneficiada com a expansão do mercado internacional decorrente da II Guerra. Ao mesmo tempo em que ocorreu o fechamento do mercado de Alemanha e Japão para o algodão, ocorreu a expansão do mercado pelos Aliados para os produtos têxteis (PRADO, 2010). O resultado foi a ativação de capacidade ociosa das máquinas e a instalação de novas fábricas. Em São Carlos foi implantada uma fábrica de meias no ano de 1942. No ano seguinte, foram implantadas duas fiações de seda e uma fábrica de toalhas (CATÁLOGO DAS INDÚSTRIAS DO ESTADO DE SÃO PAULO, 1945). Em 1944, a oficina de fundição dos Irmãos Masci lançou uma máquina de fiação batizada de "Fiandeira São Carlos". A Cia Fiação e Tecidos São Carlos, a maior do ramo, passou a funcionar em três turnos e diversificou seus ramos de atuação, passando a utilizar o caroço de algodão para diversos fins e ampliou o número de fazendas sob sua propriedade (TRUZZI, 2000). Essa empresa também se inseriu no ramo imobiliário. Fundaram a Imobiliária Lutfalla e passaram comprar fazendas e implantar loteamentos na cidade, conforme mostraremos ao abordar a relação dos industriais com a expansão urbana. Em 1948, São Carlos contava com quatro indústrias têxteis e duas usinas de

\footnotetext{
${ }^{8}$ Disponível em: http://www.portalk3.com.br/Artigo/ memoria/sao-carlos-foi-capital-nacional-dosalfaiates (acesso em novembro de 2013).
} 
beneficiar algodão (PREFEITURA MUNICIPAL DE SÃO CARLOS. Livro de impostos sobre indústrias e profissões para o ano de 1948).

No processo de abertura para um mercado interno mais amplo, os grandes estabelecimentos passaram a ser preponderantes na economia de São Carlos. Em 1930, $13 \%$ das indústrias representavam $36 \%$ do total de imposto pago para a prefeitura e, em 1948, 13\% das indústrias representavam 50\% do imposto pago. Portanto, ao mesmo tempo em que cresceu o número de indústrias, o faturamento total se concentrou em poucos estabelecimentos (PREFEITURA MUNICIPAL DE SÃO CARLOS. Livro de impostos sobre indústrias e profissões para os anos de 1930 e 1948).

Portanto, assim como em relação ao Brasil e ao estado de São Paulo nas décadas de 1930 e 1940, em São Carlos os setores que mais cresceram foram os de bens intermediários e de bens de consumo duráveis, devido principalmente ao crescimento dos ramos de construção e metal-mecânica (bens intermediários e de consumo duráveis) e mobiliário (bens de consumo duráveis). Apesar do crescimento desses ramos, no final da década de 1940, a maior parte da produção no estado de São Paulo e no município de São Carlos ainda era representada por bens de consumo não duráveis, principalmente, vestuário e alimentos (industrialização restringida).

Ao longo dessas duas décadas, a produção industrial do estado de São Paulo se concentrou na capital, que teve taxas de crescimento mais elevadas que o interior do estado (NEGRI, 1996).

\section{3 - A primeira fase da industrialização pesada em São Carlos: décadas de 1950 e 1960}

Durante as décadas de 1950 e 1960, ocorreram mudanças significativas no desenvolvimento dos ramos industriais e no porte das indústrias. Teve início a primeira fase da industrialização pesada, devido à importância que os setores de bens de consumo duráveis, bens intermediários e de capital passavam a desempenhar no crescimento econômico. Conforme apontado no capítulo anterior, são características dessa fase a intensificação da produção de bens de capital, bens intermediários e bens de consumo duráveis, e a consolidação dos estabelecimentos de grande porte, detentores de 
grande parcela da produção industrial, com um patamar mais sofisticado de produção, gerenciamento e atendimento de mercados.

Assim como o período da industrialização restringida (1930-1955), durante a primeira fase da industrialização pesada, (1956-1967), as maiores taxas de crescimento da indústria se mantiveram na região metropolitana da capital paulista. Foi somente a partir de 1967 que a indústria do interior de São Paulo apresentou crescimento superior ao da região metropolitana da capital. Nessa primeira fase da industrialização pesada, no que tange ao estado de São Paulo, as indústrias que mais cresceram foram as de bens intermediários e bens de capital, representados, sobretudo, pelos ramos de metalurgia, de materiais elétricos, de materiais de transporte e a indústria química (NEGRI, 1996).

A partir do quadro 02, mostramos como a indústria em São Carlos se inseria nesse contexto, no qual é possível visualizar as mudanças que ocorreram na indústria da cidade entre os anos de 1948 e 1965. Com os setores de bens intermediários e de bens de consumo duráveis crescendo acima dos setores de bens de consumo não duráveis, em 1965, este último já havia sido ultrapassado em relação ao número de estabelecimentos industriais. Em 1948, a produção se concentrava nos ramos de vestuário, alimentação e mobiliário, tanto em número de estabelecimentos como de produção. Em 1965, os ramos de construção, alimentação, metal-mecânica e mobiliário eram os mais representativos pelo número de estabelecimentos.

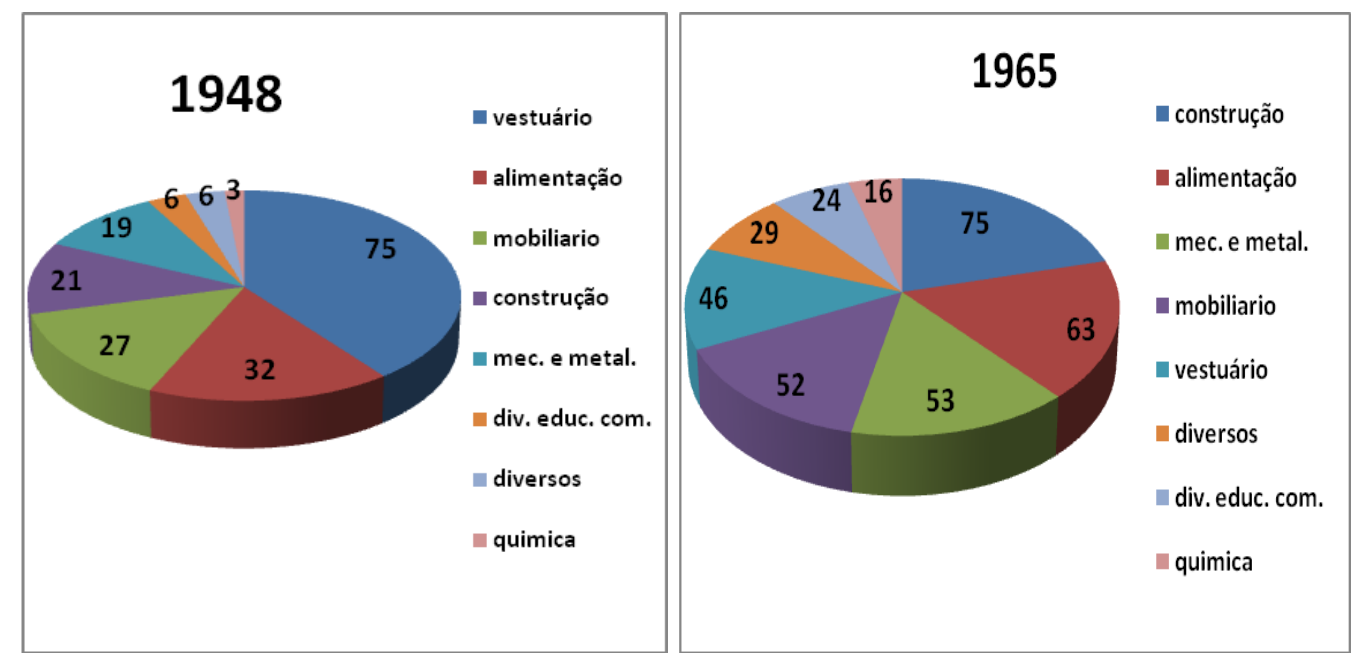

Quadro 02: São Carlos: número de estabelecimentos industriais por ramos*

\section{*Ver nota p. 75}


Fonte: Elaborado pelo autor com base em: PREFEITURA MUNICIPAL DE SÃO CARLOS. Livro de impostos sobre indústrias e profissões para o ano de 1948. São Carlos: Fundação Pró-Memória de São Carlos; CADASTRO INDUSTRIAL 1965. Rio de Janeiro: Fibge, 1968.

A tabela 11 mostra o crescimento dos ramos em São Carlos entre 1948 e 1965 . O mais notório em relação ao período da industrialização restringida é o crescimento negativo do ramo de vestuário devido principalmente ao fechamento das alfaiatarias. Contudo, foram instaladas indústrias têxteis de grande porte e o ramo de vestuário ainda era o segundo maior em valor de vendas e de número de operários, conforme mostraremos a seguir. O ramo de construção cresceu $433 \%$ em número de estabelecimentos, no entanto, eram de pequeno porte. Por isso, é necessário analisar o tamanho dos estabelecimentos no ano de 1965 e não somente o número deles. A tabela 12 mostra o número de empregados por ramos.

Tabela 11: Crescimento no número de estabelecimentos industriais em São Carlos: 1948 a 1965

\begin{tabular}{|l|c|c|c|}
\hline RAMOS INDUSTRIAIS* & $\begin{array}{c}1948 \\
\left(\mathrm{~N}^{\circ}\right)\end{array}$ & $\begin{array}{c}1965 \\
\left(\mathrm{~N}^{\circ}\right)\end{array}$ & $\begin{array}{c}\mathbf{1 9 4 8 - 1 9 6 5} \\
(\text { crescimento })\end{array}$ \\
\hline Química & 03 & 16 & $\mathbf{( 4 3 3 \% )}$ \\
\hline Diversos & 06 & 29 & $\mathbf{( 3 8 3 \% )}$ \\
\hline $\begin{array}{l}\text { Diversão, Educação e } \\
\text { Comunicação }\end{array}$ & 06 & 24 & $\mathbf{( 3 0 0 \% )}$ \\
\hline Construção & 21 & 75 & $\mathbf{( 2 5 7 \% )}$ \\
\hline Metal-Mecânica & 19 & 53 & $\mathbf{( 1 7 8 \% )}$ \\
\hline Alimentação & 32 & 63 & $\mathbf{( 9 6 , 9 \% )}$ \\
\hline Mobiliário & 27 & 52 & $\mathbf{( 9 2 , 6 \% )}$ \\
\hline Vestuário & $\mathbf{7 5}$ & 46 & $\mathbf{( - 3 8 , 6 \% )}$ \\
\hline TOTAL & $\mathbf{1 8 9}$ & $\mathbf{3 5 8}$ & $\mathbf{( 8 9 , 4 \% )}$ \\
\hline
\end{tabular}

*Ver nota p. 75

Fonte: Elaborado pelo autor com base em: PREFEITURA MUNICIPAL DE SÃO

CARLOS. Livro de impostos sobre indústrias e profissões para o ano de 1948. São Carlos: Fundação Pró-Memória de São Carlos; CADASTRO INDUSTRIAL 1965. Rio de Janeiro: Fibge, 1968. 


\begin{tabular}{|l|l|c|c|c|c|c|}
\hline $\begin{array}{l}\text { Tabela 12: Número de empresas por ramos industriais segundo o número de } \\
\text { operários - São Carlos, } 1965\end{array}$ \\
\hline Namos & & & & & \\
\hline No de operários & $\mathbf{1 ~ a 9}$ & $\mathbf{1 0}$ a 49 & $\mathbf{5 0}$ a 99 & $\mathbf{1 0 0}$ a 249 & $\mathbf{2 5 0}$ a 499 & $\mathbf{5 0 0}$ a 999 \\
\hline Metal-Mecânica & 38 & 12 & --- & 01 & 01 & 01 \\
\hline Vestuário & 25 & 11 & & 04 & 01 & --- \\
\hline Alimentação & 52 & 03 & 01 & --- & 01 & --- \\
\hline $\begin{array}{l}\text { Diversão, educação e } \\
\text { comunicação }\end{array}$ & 15 & 03 & --- & --- & --- & 01 \\
\hline Construção & 55 & 06 & --- & --- & --- & --- \\
\hline Mobiliário & 34 & 06 & 01 & -- & --- & --- \\
\hline Química & 08 & 03 & --- & --- & --- & --- \\
\hline Diversos & 32 & 04 & --- & --- & --- & --- \\
\hline TOTAL & $\mathbf{2 5 9}$ & $\mathbf{4 8}$ & $\mathbf{0 3}$ & $\mathbf{0 4}$ & $\mathbf{0 3}$ & $\mathbf{0 2}$ \\
\hline
\end{tabular}

*Ver nota p. 75

Fonte: Elaborado pelo autor com base em: CADASTRO INDUSTRIAL 1965. Rio de Janeiro: Fibge, 1968.

Como fica evidente na tabela 12 , os ramos que mais empregavam trabalhadores eram de metal-mecânica, vestuário e alimentação, sendo que as grandes indústrias pertenciam a esses ramos. As indústrias dos ramos de construção, mobiliário e química empregavam poucos operários por unidade fabril. No cadastro industrial de 1965 não havia dados sobre número de operários em 29 estabelecimentos, mas, pela natureza dos produtos fabricados e comparando aos valores de venda, percebemos que eram estabelecimentos enquadrados entre 1 a 10 operários. O quadro a seguir mostra os nomes e os produtos fabricados pelas indústrias que concentravam maior número de empregados. 


\begin{tabular}{|c|c|}
\hline \multicolumn{2}{|c|}{ Quadro 03: Indústrias com maior número de operários em São Carlos em 1965} \\
\hline $\mathbf{N}^{\circ}$ de operários & Indústrias \\
\hline 500 a 999 & $\begin{array}{l}\text { - Indústria Pereira Lopes S/A (refrigeradores) } \\
\text { - Lápis Johan Faber Indústria }\end{array}$ \\
\hline 250 a 499 & $\begin{array}{l}\text { - CIA Brasileira de Tratores } \\
\text { - Fiação e Tecelagem Germano Fehr (tecidos de algodão) } \\
\text { - Frigorífico São Carlos do Pinhal S/A (carne congelada e em conserva) }\end{array}$ \\
\hline 100 a 249 & $\begin{array}{l}\text { - CIA Fiação e Tecidos São Carlos (fios de algodão) } \\
\text { - Fábrica de Tapetes São Carlos LTDA } \\
\text { - Ibrahim Remaili e CIA LTDA (roupas de cama, mesa e banho) } \\
\text { - Tecelagem São Carlos LTDA (roupas de cama, mesa e banho) } \\
\text { - S/A Indústria Giometti (peneiras, pregos, rastelos etc.) }\end{array}$ \\
\hline 50 a 99 & $\begin{array}{l}\text { - Indústria R. Camargo S/A (móveis) } \\
\text { - Conservas Alimentícias Hero S/A (conservas de especiarias e } \\
\text { condimentos) } \\
\text { - Cooperativa de Laticínios de São Carlos (pasteurização e frigorificação } \\
\text { de leite) }\end{array}$ \\
\hline
\end{tabular}

Fonte: Elaborado pelo autor com base em: CADASTRO INDUSTRIAL 1965. Rio de Janeiro: Fibge, 1968.

O quadro 04 mostra os estabelecimentos organizados por valores de vendas. As indústrias que mais empregavam eram também as que possuíam maiores valores de venda no ano de 1965. Destacam-se a fábrica de geladeiras, com faturamento acima de 10 milhões de cruzeiros e a fábrica de tratores e o frigorífico, ambos com faturamento acima de 5 milhões de cruzeiros.

Sobre as indústrias têxteis, embora empregassem muitos funcionários, com exceção da Tapete São Carlos, nenhuma possuía valor de venda acima de 2 milhões de cruzeiros. As maiores indústrias alimentícias em valor de vendas eram o Frigorífico São Carlos do Pinhal, a indústria de conservas Hero e as cooperativas de laticínios e agrícola. A maior indústria de móveis, a R. Camargo S/A, possuía faturamento da ordem de 200 mil a 500 mil cruzeiros. Apesar do crescimento do número de indústrias da construção (75 estabelecimentos instalados em 1965), a maior indústria desse ramo possuía valor de venda entre 100 mil a 200 mil cruzeiros, e as 74 restantes menos de 100 mil cruzeiros em valor de venda. 


\begin{tabular}{|c|c|}
\hline \multicolumn{2}{|c|}{ Quadro 04: Indústrias com maiores valores de vendas em São Carlos em 1965} \\
\hline Valor de venda em CR\$ & Indústrias \\
\hline Mais de 10 milhões & - Indústria Pereira Lopes S/A (refrigeradores elétricos) \\
\hline $\begin{array}{l}\text { De } 5 \text { milhões a menos de } \\
10 \text { milhões }\end{array}$ & $\begin{array}{l}\text { - Frigorífico São Carlos do Pinhal S/A (carne congelada e em } \\
\text { conserva) } \\
\text { - CIA Brasileira de Tratores }\end{array}$ \\
\hline $\begin{array}{l}\text { De } 1 \text { milhão a menos de } 5 \\
\text { milhões }\end{array}$ & $\begin{array}{l}\text { - Lápis Johann Faber LTDA } \\
\text { - Fábrica de Tapetes São Carlos } \\
\text { - Conservas Alimentícias Hero S/A (conservas de especiarias e } \\
\text { condimentos); } \\
\text { - Cooperativa de Laticínios de São Carlos; } \\
\text { - Tecelagem São Carlos LTDA (roupas de cama, mesa e banho); } \\
\text { - Fiação e Tecelagem Germano Fehr; }\end{array}$ \\
\hline $\begin{array}{l}\text { De } 500 \text { mil a menos de } 1 \\
\text { milhão }\end{array}$ & $\begin{array}{l}\text { - Cooperativa Agrícola de São Carlos (rações para animais); } \\
\text { - Ibrahim Remaili e CIA LTDA (roupa de cama, mesa e banho); } \\
\text { - S/A Indústria Giometti (peneiras, pregos, rastelos e etc.); }\end{array}$ \\
\hline $\begin{array}{l}\text { De } 100 \text { mil a menos de } \\
500 \text { mil }\end{array}$ & $\begin{array}{l}\text { - Cooperativa Agrícola de São Carlos (beneficiamento de arroz); } \\
\text { - Indústria e Comércio de Roupas Pinhal S/A; } \\
\text { - William Sallum e CIA (fábrica de meias); } \\
\text { - Antoine Azouri e Irmão (artigos de Malha); } \\
\text { - Indústria e Comércio Cardinali LTDA (canos, tubos, mangueiras } \\
\text { e mangotes); } \\
\text { - Indústria Carlos Facchina S/A (adubos); } \\
\text { - Indústria de Papel São Carlos S/A; } \\
\text { - Indústria R. Camargo S/A (mobiliário); } \\
\text { - Dante Ciarrochi (ferramentas para máquinas destinadas à } \\
\text { agricultura); } \\
\text { - Diamantul - J K Smit e Sons S/A (máquinas e aparelhos para } \\
\text { indústrias); } \\
\text { - Gráfica Correio de São Carlos S/A; }\end{array}$ \\
\hline
\end{tabular}




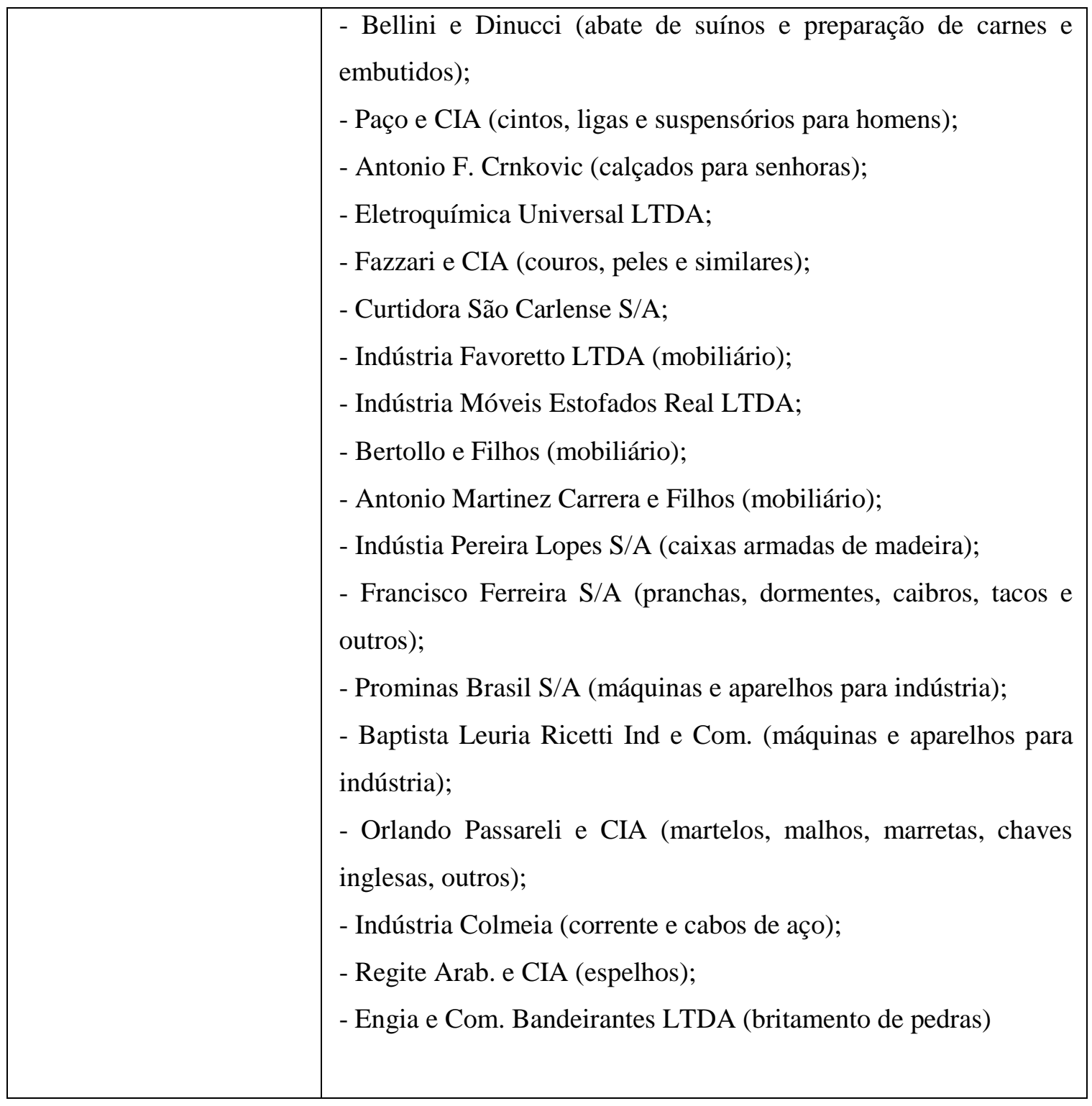

Fonte: Elaborado pelo autor com base em: CADASTRO INDUSTRIAL 1965. Rio de Janeiro: Fibge, 1968.

Em síntese, no ano de 1965, os ramos mais representativos para o total da produção industrial eram, por ordem, metal-mecânica, alimentação e vestuário, seguidos por diversão-educação-comunição (devido principalmente à indústria Johan Faber e às gráficas), mobiliário, construção e química. O grupo de indústrias classificado como “diversos" não constitui um ramo stricto sensu.

Assim, o setor industrial mais importante em São Carlos no ano de 1965 ainda era o de bens de consumo não duráveis (alimentos, vestuário e artigos de educação e comunicação), seguido por bens de consumo duráveis (móveis e eletrodomésticos), 
bens intermediários (construção e produtos para construção) e bens de capital (máquinas para indústria e agricultura).

Essa produção industrial no município estava concentrada em poucos estabelecimentos. Apenas nove indústrias (2,5\% do total) possuíam um valor de venda superior a 1 milhão de cruzeiros e as 41 indústrias (11\% do total) listadas no quadro 04 possuíam valor de venda entre 100 mil e menos de 1 milhão de cruzeiros, enquanto que as 317 restantes (89\%) possuíam valor de venda inferior a 100 mil cruzeiros.

No ano de 1969, um guia de informações de São Carlos listava os nomes e endereços de 409 indústrias instaladas naquele ano (SÃO CARLOS: guia de informações, 1969), contando um aumento de $15 \%$ no número de estabelecimentos industriais em relação a 1965. Entre as indústrias instaladas nesse período, destacam-se pela importância a Dissoltex Indústrias Químicas LTDA, do ramo de tintas, esmaltes, solventes e processamento do couro ${ }^{9}$ e a Construtora Araguaia S/A, especializada na construção de estradas de rodagem ${ }^{10}$, ambas localizadas às margens da rodovia Washington Luís.

\section{4 - As indústrias e o sistema de transporte sobre trilhos}

O sistema de transporte sobre trilhos, formado pela ferrovia e pelo bonde elétrico, foi fator determinante para a localização das indústrias, tanto no âmbito nacional e estadual quanto no espaço intraurbano. Nesse sentido, Villaça (2001) aponta que a compreensão crítica das transformações espaciais urbanas relacionadas unicamente às etapas de desenvolvimento econômico do país, explicam o processo geral de urbanização, de caráter regional. No entanto, as questões específicas do arranjo territorial do espaço intraurbano, v.g., a localização dos loteamentos, dos grupos sociais, das atividades produtivas, de comércio e cultura, devem ser buscadas, sobretudo, na relação com a estrutura de transportes.

Exemplo marcante dessa questão foi demonstrado por Petrone (1958) na cidade de São Paulo no final do século XIX. O autor mostra que a cidade se expandiu com maior intensidade exatamente nas direções onde se localizavam as áreas industriais, a saber,

\footnotetext{
${ }^{9}$ Disponível em: http://www.dissoltex.com.br (acesso em janeiro de 2015)

${ }^{10}$ Disponível em: http://www.planetabrasileiro.com/araguaia-construtora-brasileira-derodovias-s-a-sao-carlos-sp-F1407C70719D4 (acesso em janeiro de 215)
} 
nas direções Oeste, Leste e Sul. Pelo fato de as estradas de ferro terem aproveitado as áreas de fundo de vale, as indústrias foram atraídas para esses locais, pois era o principal meio de transporte para entrada e saída de mercadorias. Com a oferta de emprego nas indústrias, as áreas de várzea foram os locais onde ocorreu a expansão urbana com maior intensidade. Esse fato explica, segundo o autor, a formação da paisagem urbana, marcada pelo desenvolvimento de bairros mistos, ou seja, industriais e residenciais a um só tempo. Na cidade de São Carlos, ocorreu fato semelhante, mas em escala menor do que na capital, conforme mostraremos.

A implantação em São Carlos, pela Companhia Paulista de Estradas de Ferro, do ramal ferroviário que vinha de Rio Claro, ocorreu em 1884 por iniciativa e com capital do Conde do Pinhal. Seu objetivo era transportar o café para o porto de Santos e expandir a cultura cafeeira. Nessa data, a área urbana que hoje corresponde ao centro já havia se consolidado e a ferrovia foi implantada tangenciando a cidade na parte sudoeste. A partir de então, a estação ferroviária tornou-se o ponto principal de entrada e saída de mercadorias e pessoas. Além do transporte do café, que era o produto principal, o trem também se encarregava do transporte intermunicipal de pessoas e de mercadorias que chegavam de outras partes do país e do exterior, atendendo à demanda das lojas e do nascente mercado interno com produtos importados. O mesmo trem que levava o café trazia as encomendas das lojas de comerciantes locais e também de materiais para atividades industriais e de construção civil, como casas, escolas, teatros, hospitais, usina de energia elétrica, bonde, etc. (TRUZZI, 2000).

O mapa 08 mostra, no ano de 1930, a área urbana, o sistema de transporte sobre trilhos e a localização das indústrias. Como pode ser observado, o bonde elétrico circulava pela área central, local de moradia da elite da cidade, e pelos bairros Vila Nery e Vila Puresa, onde, segundo Devescovi (1987) e entrevistas ${ }^{11}$, predominavam moradores de classe média. Nos bairros da zona sul, Vila Prado, Vila Marcelino e Vila Isabel, onde se concentrava a população operária, o bonde não circulava (Correio de São Carlos, 13 de janeiro de 1938).

\footnotetext{
${ }^{11}$ Entrevistas concedidas por empresários industriais e do ramo imobiliário em São Carlos: Ítalo Cardinali Filho em 30/06/2014, Fernando Pereira Lopes em 30/06/2014, Irineu Massari em 01/07/2014 e Mario Maffei em 22/10/2014.
} 


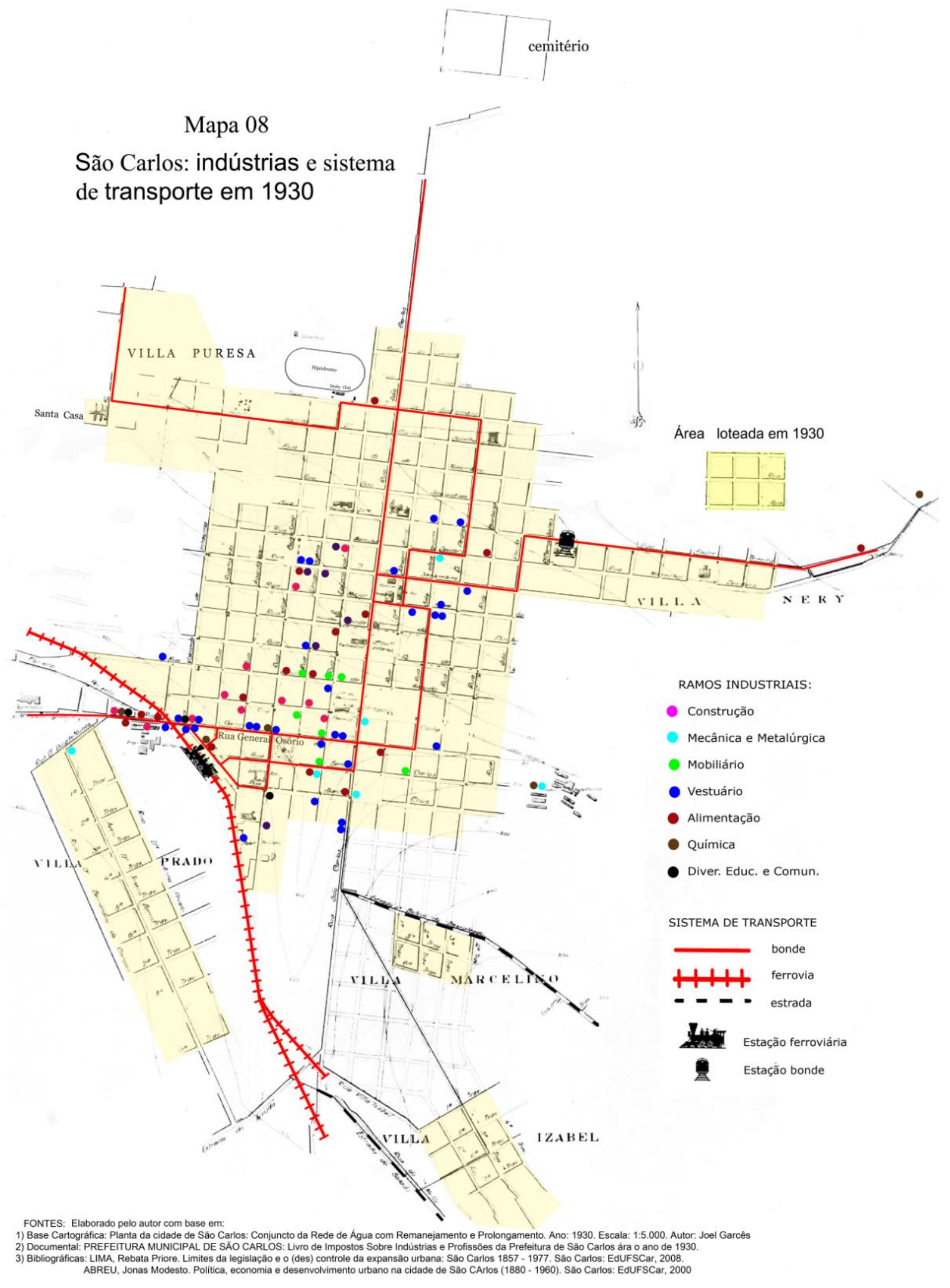


Com o crescimento industrial nas décadas de 1930 e 1940, as indústrias se concentraram próximas à estação ferroviária e ao bonde, sobretudo na região sudoeste, próxima à estação ferroviária. Essa área se localizava entre o limite da área que corresponde aos primeiros arruamentos e os bairros Vila Prado, Vila Marcelino e Vila Isabel. Desse modo, as moradias dos trabalhadores se localizaram estrategicamente do ponto de vista da locomoção para as indústrias, permitindo um acesso fácil, por pedestres ou usuários do bonde, de qualquer ponto da cidade. A Vila Isabel era o bairro que se situava mais distante das indústrias e a 14 quadras do acesso ao bonde.

Através de entrevistas com industriais ${ }^{12}$ de São Carlos, relatamos a importância da ferrovia para a localização das indústrias. O Sr. Mario Maffei, ex-prefeito de São Carlos, nascido em 1926 e proprietário da Indústria S/A Miguel Giometti, fundada em 1916, relata como os produtos acabados e as matérias-primas eram transportadas pelo trem. Sua indústria fabrica produtos de madeira e aço (rastelos, peneiras, arames, pregos, etc) destinados às lavouras e fabricava também sorvetes de palito. Mario Maffei relatou o seguinte na entrevista:

"Naquele tempo os trens tinham uma seção de bagageiros que parava em todas as cidades e essa seção levava encomendas, chamava 'encomendas', então os sorvetes eram feitos em barricas, fechados, em volta colocava serragem e gelo que nós tínhamos e punham nos trens de manhã. De manhã saíam cinqüenta, sessenta barricas dessas e iam distribuindo nas cidadezinhas aqueles sorvetes de palito"

O Sr. Mario Maffei cita os sorvetes, no entanto os principais produtos transportados pelo trem eram os artigos de madeira e aço para a produção agrícola e construção. Esses produtos eram transportados para o norte do Paraná, sul de Minas Gerais, ao oeste, próximo a Rio Preto, e ao leste, até Campinas, ou seja, onde havia plantações de café que utilizavam os produtos de sua indústria. Na década de 1960, algumas estradas foram abertas, mas os produtos acabados ainda eram transportados por trem, que, segundo Mário, havia se tornado mais rápido.

Sobre a matéria-prima, Mario Maffei relata que a madeira provinha das fazendas de São Carlos, cortadas nas serrarias do próprio município. O aço, no início, era importado

${ }^{12}$ Entrevistas concedidas por empresários industriais em São Carlos: Fernando Pereira Lopes em 30/06/2014 e Mario Maffei em 22/10/2014. 
da Alemanha, trazido de trem de Santos para São Carlos. A indústria S/A Miguel Giometti foi uma das primeiras a comprar o aço da Companhia Siderúrgica BelgoMineira, após a Revolução de 1932. Na década de 1940, passaram a comprar da Companhia Siderúrgica Nacional (CSN).

A Indústria Pereira Lopes (IPL), fundada em 1946 no Jardim Bela Vista, recebia pelo trem as chapas de aço para fabricação de geladeiras e fogões, através de um ramal que se aproximava da indústria, mas que hoje está desativado. As chapas eram compradas do estado de Minas Gerais e eram transportadas pelo trem, mas os produtos acabados eram transportados por caminhões da própria indústria. Segundo Fernando Pereira Lopes, neto de Ernesto Pereira Lopes e Emílio Fehr, ambos ex-industriais e expolíticos de São Carlos, em entrevista, relatou seguinte:

\footnotetext{
"as fábricas aqui, as mais antigas, todas elas margeavam a linha férrea, porque elas tinham derivação do terminal férreo para dentro das fábricas, isso há muito tempo atrás. Por exemplo, a Companhia Tecidos São Carlos, chamado Tecidão, se você for lá naquele prédio, tem um ramal ferroviário dentro dele. A própria indústria Germano Fehr, ela era encostada na linha por conta de um ramal ferroviário que vinha, onde está a indústria Rossignollo hoje. Mas onde é o Tecidão, em frente a fábrica de lápis, na José Bonifácio, ali, aquele prédio é nosso inclusive, ali você entra e tem um lugar onde o trem entrava e descarregava, tem um terminalzinho de trem. Nós andamos pra trás nisso aí, nós andamos pra trás! Quem não tinha os galpões para fazer, então os trens descarregavam ali. Eu não sou dessa época, mas a gente ouve falar. Os trens descarregavam ali onde tem uns barracões que o trem descarregava. Você tinha seus depósitos lá e os transportes de matéria-prima eram basicamente ferroviários [...] Eu me lembro de trem de carga de matéria-prima e de passageiros, isso a gente tinha muito (sic)'”.
}

O mapa 09 mostra no ano de 1948, a distribuição das indústrias no território segundo seus ramos industriais, e a área urbanizada. 
Mapa 09

São Carlos: Indústrias e

sistema de transporte em 1948

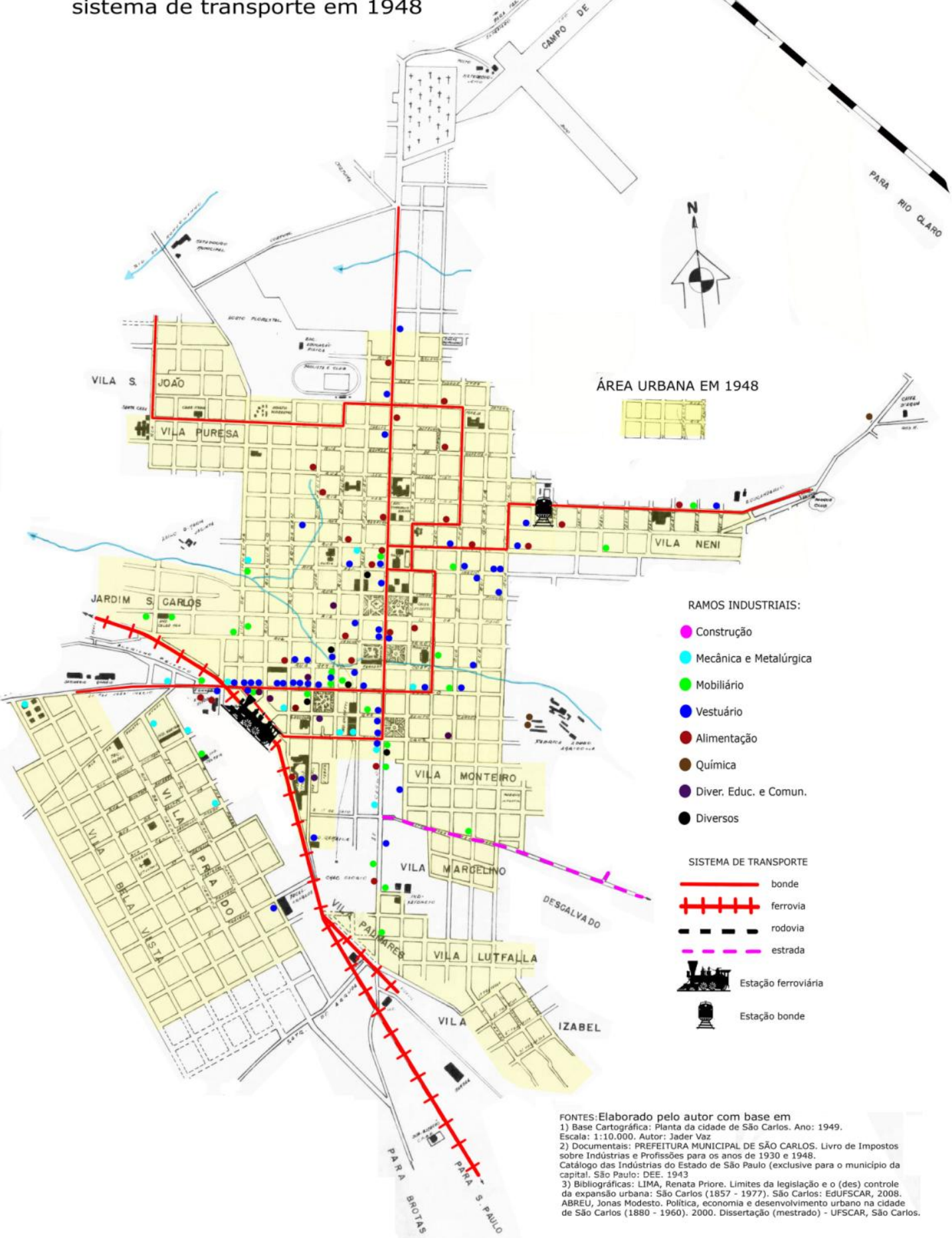


As maiores indústrias fundadas ao longo das décadas de 1930 e 1940 se instalaram próximas à estação ferroviária. É o caso da Indústria Pereira Lopes (atual Eletrolux), fundada em 1946 no Jardim Bela Vista e também das indústrias de móveis Colmeia, Favoretto, da Fiação de Sedas São Carlos S/A, da fábrica de peneiras e pregos Jorge Narvaes e Cia. e da Fiação e Tecelagem Germano Fehr (PREFEITURA MUNICIPAL DE SÃO CARLOS. Livro de impostos sobre indústrias e profissões para os anos de 1930 e 1948; CATÁlOGO DAS INDÚSTRIAS DO ESTADO DE SÃO PAULO, 1945).

Em relação aos ramos industriais, a análise da localização não indica um padrão de localização, ou seja, as indústrias se dispersaram territorialmente independente dos produtos fabricados. No próximo item, analisaremos o processo de urbanização até 1949 e como se vinculam a localização das indústrias e dos loteamentos.

\title{
2.5 - As moradias próximas ao local de trabalho e concentração das atividades econômicas
}

\author{
“[...] é uma lei de toda economia mercantil \\ em desenvolvimento e, sobretudo, da \\ economia capitalista: a população \\ industrial (vale dizer, não agrícola) cresce \\ mais rapidamente que a população \\ agrícola, com o crescente deslocamento de \\ massas da agricultura para a indústria” \\ (LÊEIN, 1982:32)
}

Com a crise agrícola e o desenvolvimento da indústria, o locus da produção se deslocou do campo para a cidade, com intensificação das instalações de fábricas em bairros próximos ao centro e a formação de bairros com grande concentração de população operária. Os processos de crescimento econômico e urbano adquiriram outra lógica de acumulação e organização espacial, ou seja, não mais se dava no sentido de diversificação do complexo cafeeiro, mas vinculada à produção industrial voltada para o mercado interno. É nesta etapa que podemos falar da formação do urbano em São Carlos, ou seja, quando as aglomerações populacionais deixam de servir às necessidades 
da atividade primária e passam a servir às necessidades inadiáveis da população, com verdadeira 'especialização do espaço’ (SANTOS, 1979:71).

Segundo Rossini (1988:96), no final da década de 1920, a urbanização do interior paulista propiciou investimentos privados em estabelecimentos comerciais em companhias de energia, de telefone, de meios de transporte, bancos, instituições de ensino etc., reforçando o setor urbano. Nesse sentido, Santos (1998:27), indica que o termo "industrialização" não é tomado apenas como criação de atividades industriais nos lugares, mas como processo social complexo, que tanto inclui a formação de um mercado nacional, quanto os esforços de equipamento do território para torná-lo integrado, i.e., expansão do setor terciário e expansão urbana. Para Lênin (1982) "o objeto da Economia Política não é simplesmente a 'produção', mas as relações sociais que existem entre os homens na produção, a estrutura social da produção".

Desse modo, considerando as infraestruturas e o setor terciário junto com a industrialização, elaboramos os mapas da expansão urbana relacionada com as atividades econômicas nas décadas de 1930 e 1940, indicando os loteamentos e a localização das atividades econômicas, a saber, indústrias, comércio e bancos.

Desde a fundação de São Carlos (1857), até a data de implantação da ferrovia (1884), o crescimento da malha urbana ocorreu através do prolongamento da Rua São Carlos, no sentido norte-sul. A partir de 1889 até 1893, foram implantados os primeiros loteamentos em São Carlos: Vila Nery a nordeste, Vila Pureza a noroeste, Vila Isabel a sudeste e a Vila Prado a sudoeste. Até 1930, foi implantado mais um loteamento, a Vila Marcelino, próximo a Vila Isabel, conforme mostra mapa 10.

Sobre os melhoramentos urbanos, em 1932 (PIZA, 1933:409) constava o seguinte:

\footnotetext{
"a cidade é dotada de abastecimento de agua e de redes de esgotos. Conta com 3.500 predios, as ruas são calçadas a parallelepipedos e arborizadas com Lingustrum Japonica. O centro telephonico, com 600 apparelhos, é ligado á rêde geral do Estado. A iluminação electrica é fornecida por empreza local a 600 réis o Kilowatt" (sic)
}

São Carlos era conhecida por suas escolas que atraiam estudantes de outros municípios (TRUZZI, 2000). Em 1932, contava com 35 escolas primárias (3.224 alunos), três escolas secundárias (189 alunos), três escolas profissionalizantes (371 
alunos) e a Escola de Direito Moraes de Barros, com 382 alunos. Contava também com três jornais, entidades recreativas e esportivas, quatro templos católicos e um protestante (PIZA, 1933:408).

As atividades econômicas em 1930 se concentravam próximas à rua General Osório e à rua São Carlos, ou seja, nas principais vias onde o bonde circulava. As indústrias e bancos se instalaram a uma distância máxima de três quarteirões do trajeto do bonde. Percebe-se, contudo, que a parte das ruas citadas acima, que contava com mais estabelecimentos de comércio e indústrias, era próxima à estação ferroviária. Os bancos se situavam bem no centro da área urbana, próximos à catedral e ao jardim público, a saber, o Banco do Comércio e Indústria (rua São Carlos, n²43), o Banco Comercial do Estado de São Paulo (rua Major José Ignácio, n66), o Banco de São Paulo e o Banco Francês e Italiano para a América do Sul (ambos na rua Major José Ignácio, $\mathrm{n}^{\circ}$ 56) [PREFEITURA MUNICIPAL DE SÃO CARLOS, 1930]. Os endereços dessa não correspondem ao atual. 


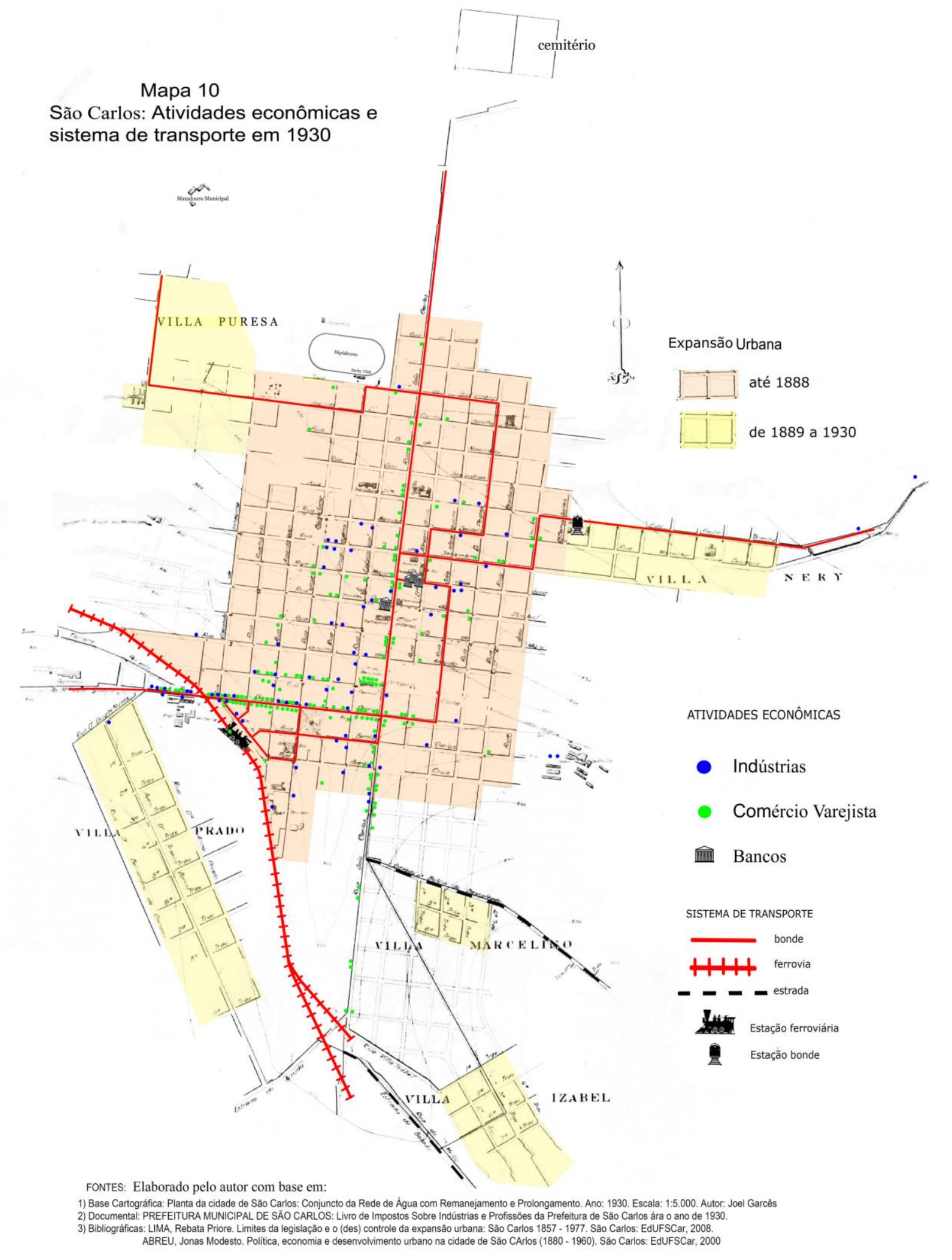


Um relato publicado no Jornal Correio de São Carlos, em 1943, explica o processo de urbanização da Vila Prado, onde se concentrava a maioria da população operária em São Carlos:

\begin{abstract}
"A Vila Prado foi constituida por um processo muito simples de loteamentos da Fazenda Bela Vista [...] Às primeiras industrias ali instaladas - uma torrefação, uma fábrica de doces e bebidas sucederam-se novas e importantes fábricas, atraindo mais e mais operários. Aparecendo alguns predios mais vistosos. Logo mais, um sobrado. A cidade ia crescendo, e com ela, a Vila Prado, que mais tarde acabou sendo incorporada ao perímetro urbano [...] Em 1934 creou-se o Grupo Escolar. Em 1937 foi autorizada a construção da rede de abastecimento de agua, inaugurada em 1939. A Vila Prado extendeu-se mais ainda, originando a Vila Bela Vista (sic)." [Correio de São Carlos, São Carlos, 27 de junho de 1943]
\end{abstract}

Entre 1930 e 1949, houve significativo crescimento da população urbana e da área urbana destinada à moradia dessa população. Em comparação com Araraquara e Rio Claro, durante a década de 1930, a economia agrária de São Carlos declinou ainda mais que suas vizinhas, gerando êxodo rural em direção ao seu centro urbano e para outras regiões. Entre 1934 e 1950, a população total de 51.620 habitantes passou para 47.731. Mesmo com esse decréscimo, a população urbana cresceu de 20.791 (40\%) em 1935, para 32.703 (69\%) em 1950 (CENSO DEMOGRÁFICO: Estado de São Paulo. Recenseamento Geral de 1950), o que resultou em aumento de 11.912 habitantes urbanos $(57 \%)$, em apenas 15 anos.

A partir de 1935, o processo de parcelamento do solo urbano se volta para atender esse êxodo rural que se iniciou com a crise de 1929. Entre 1935 e 1949, foram implantados 12 loteamentos (LIMA, 2007:78), totalizando uma área de 176 hectares em 15 anos, como pode ser observado no mapa 11, que representa, além da implantação de loteamentos até 1949, a distribuição das atividades econômicas no ano de 1948.

No mapa 11, mostramos a localização das indústrias, do comércio e dos bancos no ano de 1948. 
Mapa 11

São Carlos: Atividades econômicas e sistema de transporte em 1948
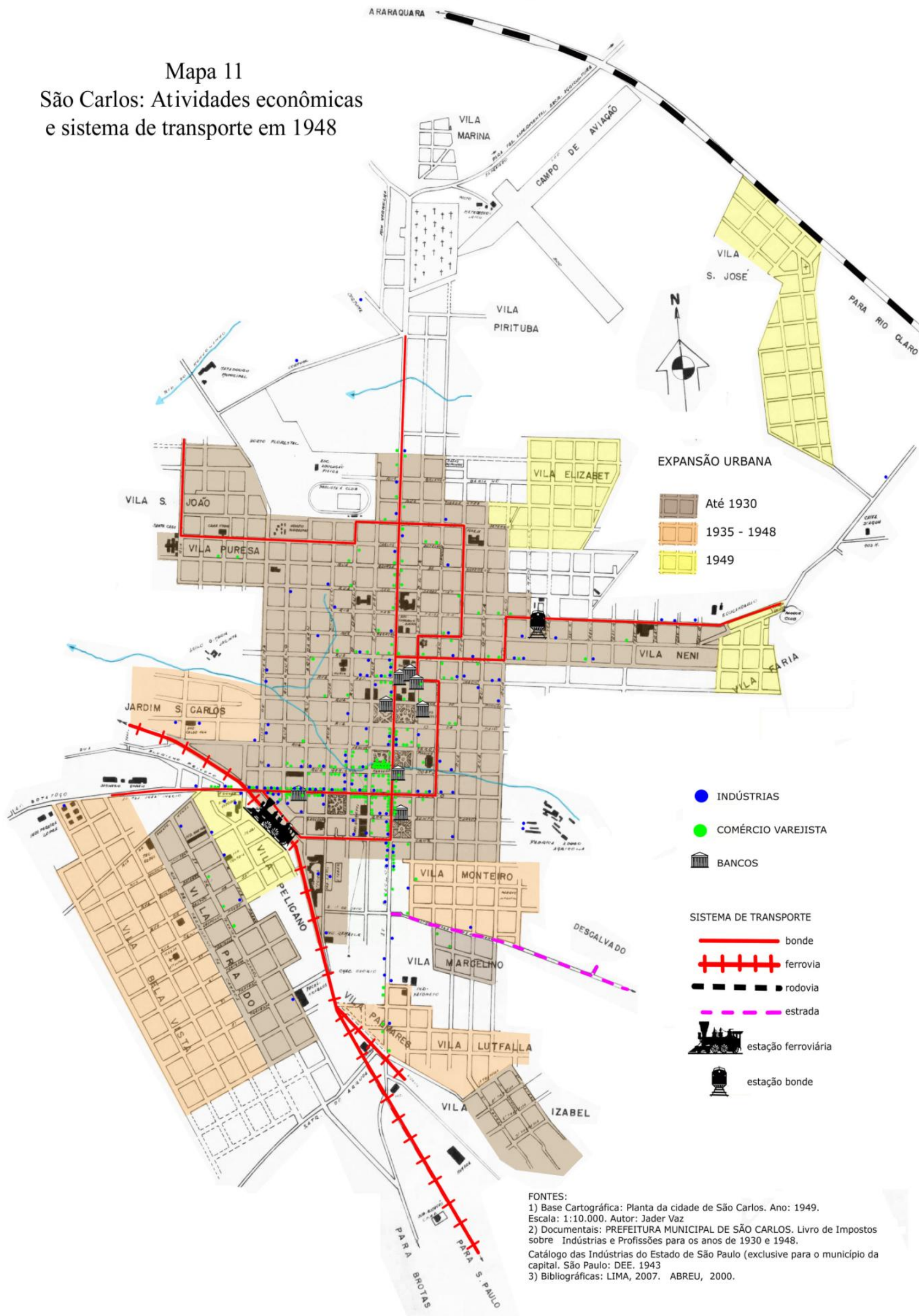
A distribuição do comércio se concentrou em dois eixos principais: a rua General Osório e a rua São Carlos. Em relação aos bancos, foram fundados mais três: a Caixa Econômica (esquina da rua Alexandrina com a rua Conde do Pinhal), o Banco Paulista de Comércio S/A (General Osório, nº172) e o Banco Moreira Salles S/A (rua São Carlos, nº190) [PREFEITURA MUNICIPAL DE SÃO CARLOS, 1948].

Entre 1935 e 1948, todos os loteamentos se localizaram próximos à estação ferroviária, às indústrias e ao comércio. Conforme apontado no item anterior, a maioria das indústrias instaladas pós-1930 se localizavam no início da Rua São Carlos, na região sul. Entre 1935 e 1948 foram implantados os seguintes loteamentos: Jardim São Carlos (1935), Vila Bela Vista (1939), Vila Irene (1940), Vila Palmares (1948), Vila Lutfalla (1948) Vila Sônia (1948) e Vila Monteiro (1948).

Em 1935, foi implantado o Jardim São Carlos, próximo à estação ferroviária. Esse loteamento foi uma continuação das tradicionais ruas Conde do Pinhal e 13 de Maio, para além do Córrego do Gregório que cruza a área onde se concentra o comércio varejista. Assim, o Jardim São Carlos começa no Córrego Gregório e termina na ferrovia. O maior loteamento de São Carlos até a década de 1940, o Jardim Bela Vista, foi implantado em 1939 por um proprietário de uma fábrica de meias e era uma extensão da Vila Prado, localizado próximo às indústrias, na zona sul. Em um artigo publicado em 1943 no Jornal Correio de São Carlos lê-se uma descrição sobre a implantação do loteamento Bela Vista:

"São Carlos, como quasi todas as grandes cidades, tem se desenvolvido sem um plano previamente estabelecido. Enquanto que ainda há no perímetro urbano, mesmo no perímetro central, extensas áreas sem edificação, a cidade continua a se "esparramar", como um polvo a extender seus tentáculos. Assim surgiram os nossos inúmeros bairros - Vilas Prado, Neri, Isabel, Pureza, Marcelino, Matias, Municipal, Jardim São Carlos, etc. Ainda recentemente, assistimos ao nascimento de um novo bairro, parte situado na zona suburbana e parte na zona rural - a Vila Bela Vista. Esses 292 alqueires de terra, fichados em 1937, na Prefeitura, em nome de Sallum e Abdelnur sob o nome "Bela Vista", constituem hoje uma pequena cidade além da Vila Prado, com mais de 200 prédios, além de muitos outros ainda em construção ou em projeto [...]Tais Bairros são formados graças a um processo, aliás já utilizado antigamente, e que é de interesse comercial 
de quem o aplica, e ao mesmo tempo de interesse para a coletividade: o loteamento. Terras mais ou menos próximas aos centros urbanos, pouco interessantes para cultura são loteadas e vendidas aos pedacinhos, em condições módicas para quem deseja construir casas, em geral pequenas e para sua própria residência. Em São Carlos, de todos os arrabaldos o mais importante é, sem dúvida, a Vila Prado [...] Ali e nas adjacências se concentra quase toda a população operária sancarlense, num total que ultrapassa 5.000 pessoas, que habitam cerca de 1.000 casas. As maiores industrias locais tambem se situam nesse prospero bairro, que é dos mais bem situados não só geografica, como topograficamente, proximo ao leito da estrada de ferro (sic)". [Correios de São Carlos, São Carlos, 27 de junho de 1943]

Em 1948, foi implantado o loteamento Vila Monteiro, que também se localizava próximo às indústrias, porém verificamos que as habitações não eram majoritariamente de operários. Segundo Abreu (2000:67), esse loteamento foi um exemplo evidente da promissora atividade comercial ligada ao o mercado imobiliário que doravante ocupou oficialmente a função iniciada pelos poderes públicos locais. Abaixo, seguem texto e imagens (figuras 08, 09, 10 e 11) da propaganda desse loteamento, publicada no jornal Correio de São Carlos em 1950, destacando a transformação da área rural em urbana:

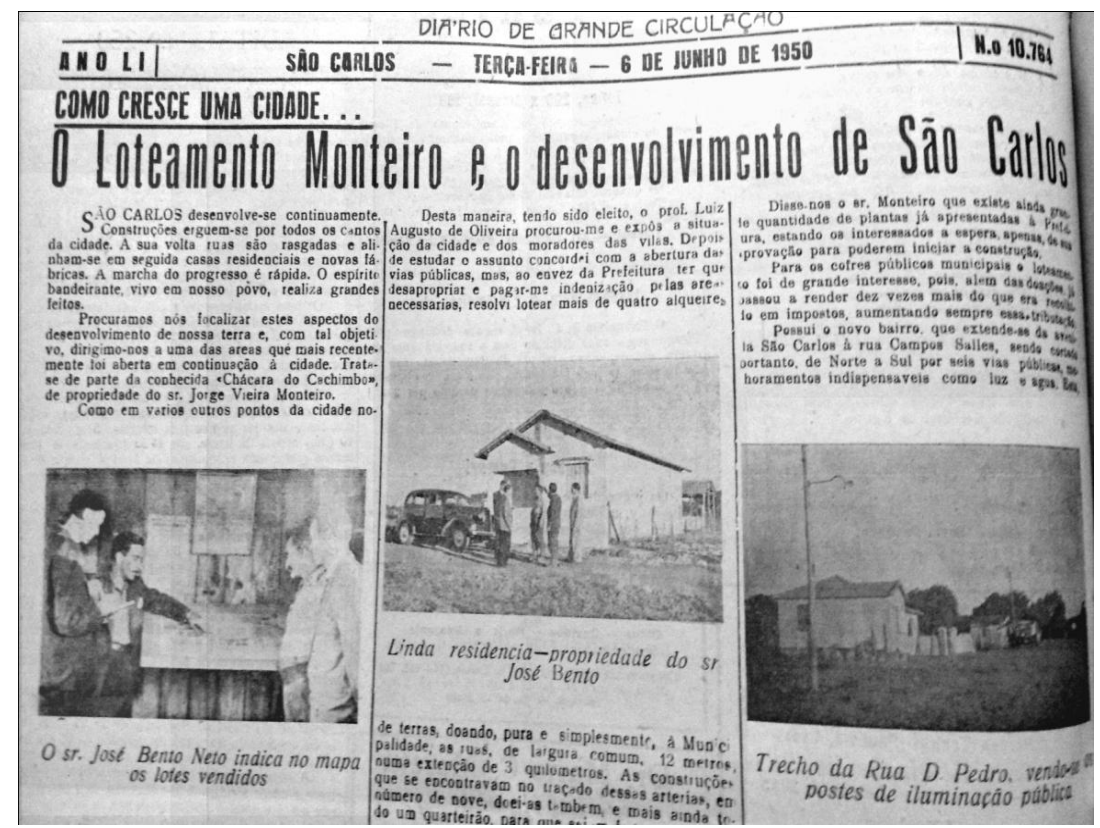

Figura 08: Anúncio loteamento Vila Monteiro, 1950.

Fonte: Correio de São Carlos, 06 de junho de 1950. 


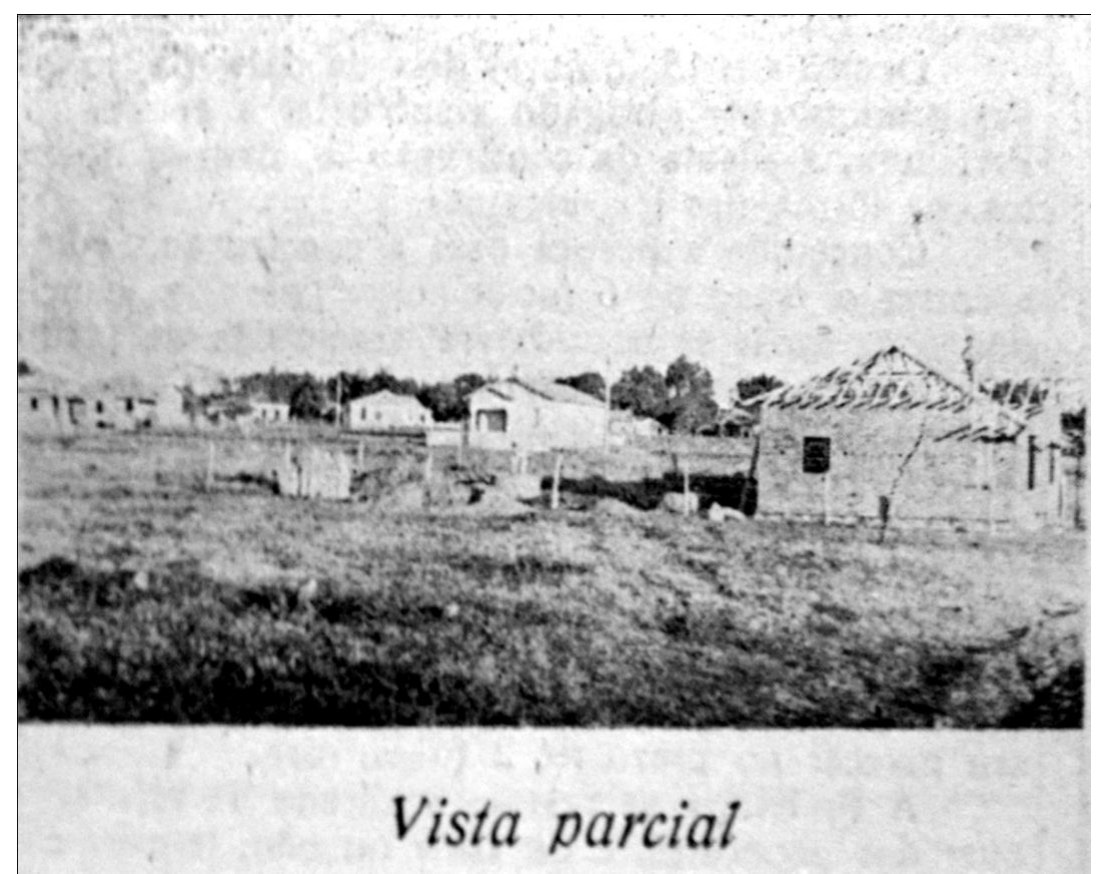

Figura 09: Vista Parcial Vila Monteiro

Fonte: Correio de São Carlos, 06 de junho de 1950.

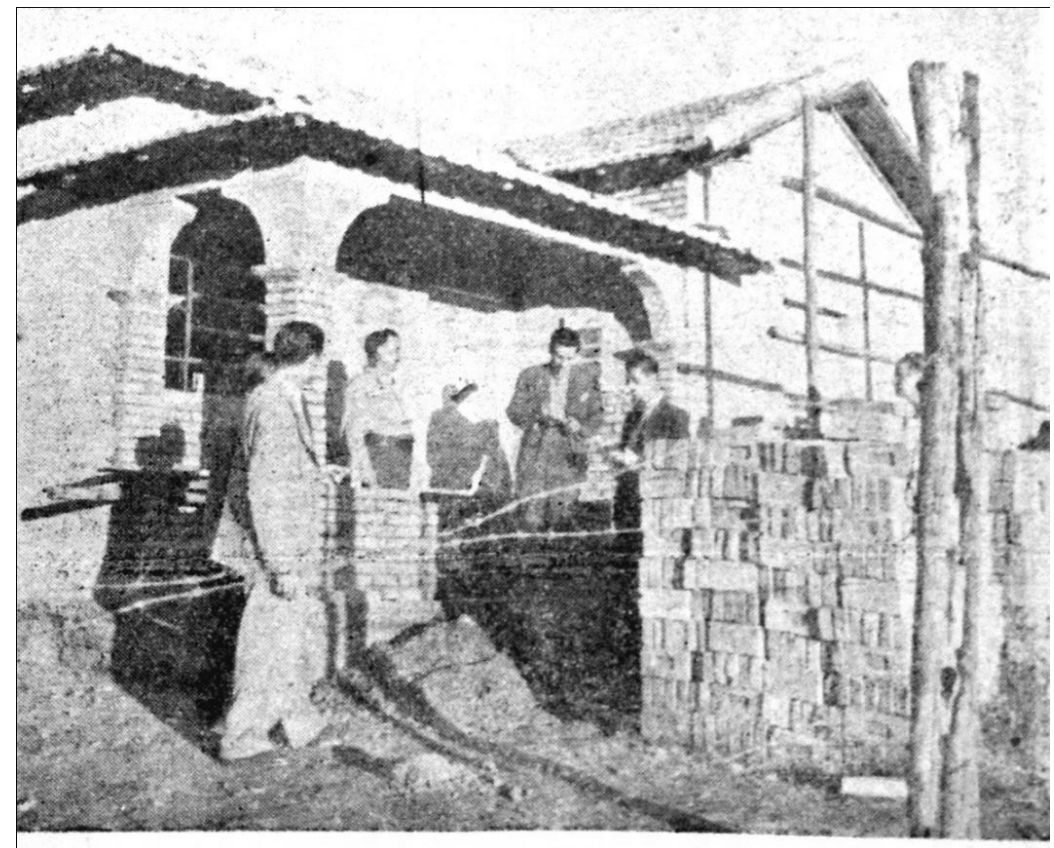

\section{Fina residencia quasi terminada}

Figura 10: Construção de residência, Vila Monteiro, 1950.

Fonte: Correio de São Carlos, 06 de junho de 1950. 
São Carlos desenvolve-se continuamente. Construções erguem-se por todos os cantos da cidade. A sua volta ruas são rasgadas e alinham-se em seguidas casas residenciais e novas fábricas [...] Procuramos nós focalizar estes aspectos do desenvolvimento de nossa terra e, com tal objetivo, dirigimo-nos a uma das áreas que mais recentemente foi aberta em continuação à cidade. Trata-se de parte da conhecida "Chácara do Cachimbo", de propriedade do Sr. Jorge Vieira Monteiro.Como em vários outros pontos da cidade notamos logo a chegada, por toda a extensão de terreno há pouco loteada, grande atividade. Grupos de casas já construídas, cada uma com sua vida normal de trabalho, crianças à volta, fumaça pela chaminé. Casas em construção: pedreiros levantando paredes, amassando reboco, colocando telhas.

Essa área de terra foi dividida em 331 lotes, de acordo com as posses de pessoas dos mais variados rendimentos. Ao que fomos informados, até ontem, já haviam sido vendidos 258 lotes. Percorrendo e examinando detalhadamente aquela nova parte da cidade contamos vinte e duas casas já construídas e 13 ainda em construção. Possui o novo bairro, que estende-se da avenida São Carlos à rua Campos Salles, sendo cortado portanto, de Norte a Sul por seis vias públicas, melhoramentos indispensáveis como luz e água. Esta, até a segunda rua acima da Santa Cruz pode ser ligada a rede de água da cidade. Acima, por hora, são construídos poços, mas em breve, com a construção da caixa da Vila Marcelino, não mais serão necessários. Com o fim de facilitar a comunicação da primeira rua além da rua Santa Cruz, com a avenida São Carlos, poderia, talvez, a Prefeitura desapropriar um pequeno trecho de quintal, com perto de 40 metros, tornando, desta maneira, uniforme o traçado da cidade." (Correio de São Carlos, 06 de junho de 1950) 


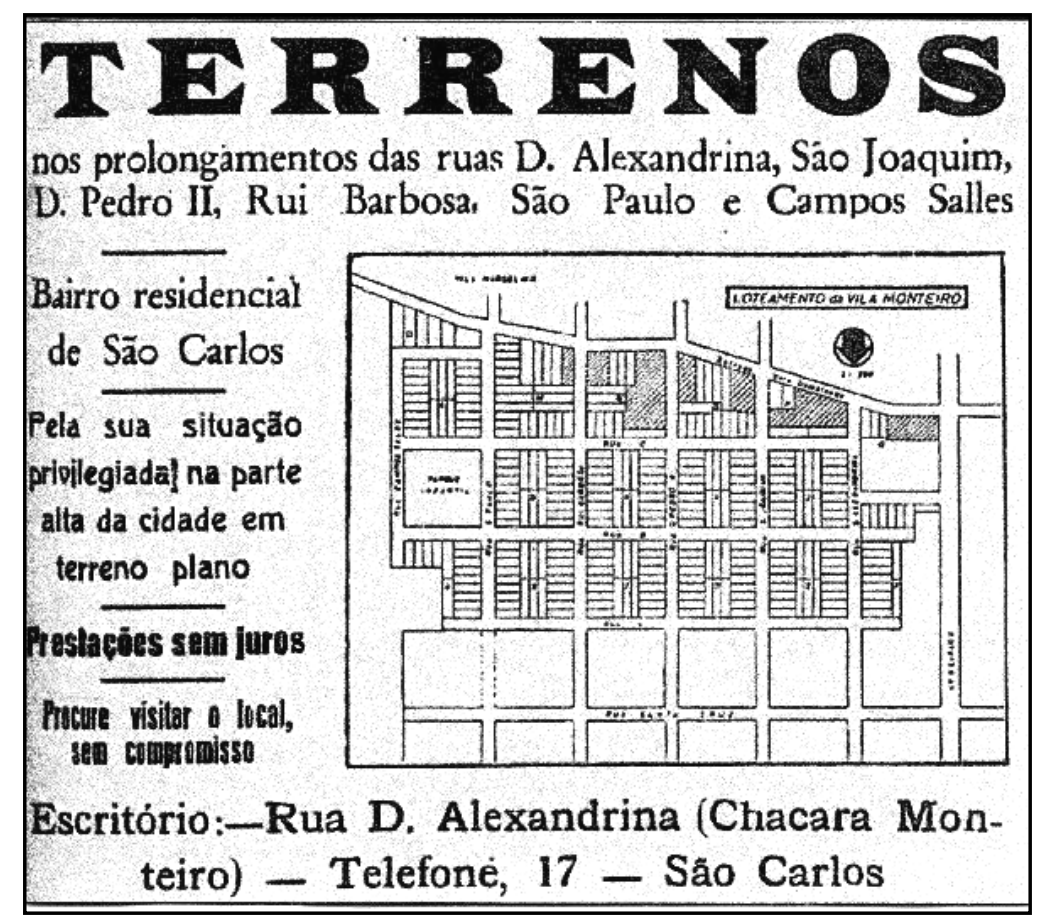

Figura 11: Propaganda da primeira gleba do Loteamento Vila Monteiro, 1950.

Fonte: Correio de São Carlos, 02 de fevereiro de 1950

Até 1948, todos os loteamentos foram implantados próximos às indústrias e, embora não fossem exclusivamente destinados aos operários, a maioria das moradias eram destinadas a essa classe. Portanto, se o processo de industrialização impõe um ritmo e uma lógica à urbanização, o período de 1935 a 1948 pode ser considerado como paradigmático em São Carlos. Os 106,63 hectares de loteamentos implantados nesse período se localizaram ao redor das concentrações industriais, sendo que a localização das indústrias e demais atividades econômicas se concentraram próximas à estação ferroviária, em área bem servida pelo bonde elétrico, ou seja, a localização do transporte sobre trilhos determinou a localização das atividades econômicas que, por sua vez, determinou a localização dos loteamentos e das moradias.

\section{6 - O sistema rodoviário e a ruptura da proximidade entre moradia e trabalho}

O ano de 1949 revela um novo direcionamento na expansão urbana. Foram aprovados cinco novos loteamentos (69,8 hectares), conforme pode ser observado no 
mapa 11: a Vila Elizabeth, Vila Pelicano, Vila São José, Vila Faria e Vila Leonardo (LIMA,2007). Desses loteamentos, apenas a Vila Pelicano se localizou na região sul, próxima à estação ferroviária. Os demais bairros se concentraram nas regiões nordeste e leste da cidade, acompanhando os novos eixos de expansão da cidade.

Essa mudança deve-se à construção da rodovia e à mobilidade proporcionada pelo automóvel, que rompeu com a fixidez espacial das indústrias e das moradias próximas ao sistema de transporte sobre trilhos. Em 1938, uma matéria do jornal Correio de São Carlos já solicitava ao governo do estado a implantação de rodovias que ligassem São Carlos a outras cidades, tendo em vista o desenvolvimento do município. Segundo a matéria, o renascimento de São Carlos passava pela construção do sistema rodoviário, e eram propostas a construção de rodovias, como pode ser observado pela figura 12 (Correio de São Carlos, 27 de fevereiro de 1938).

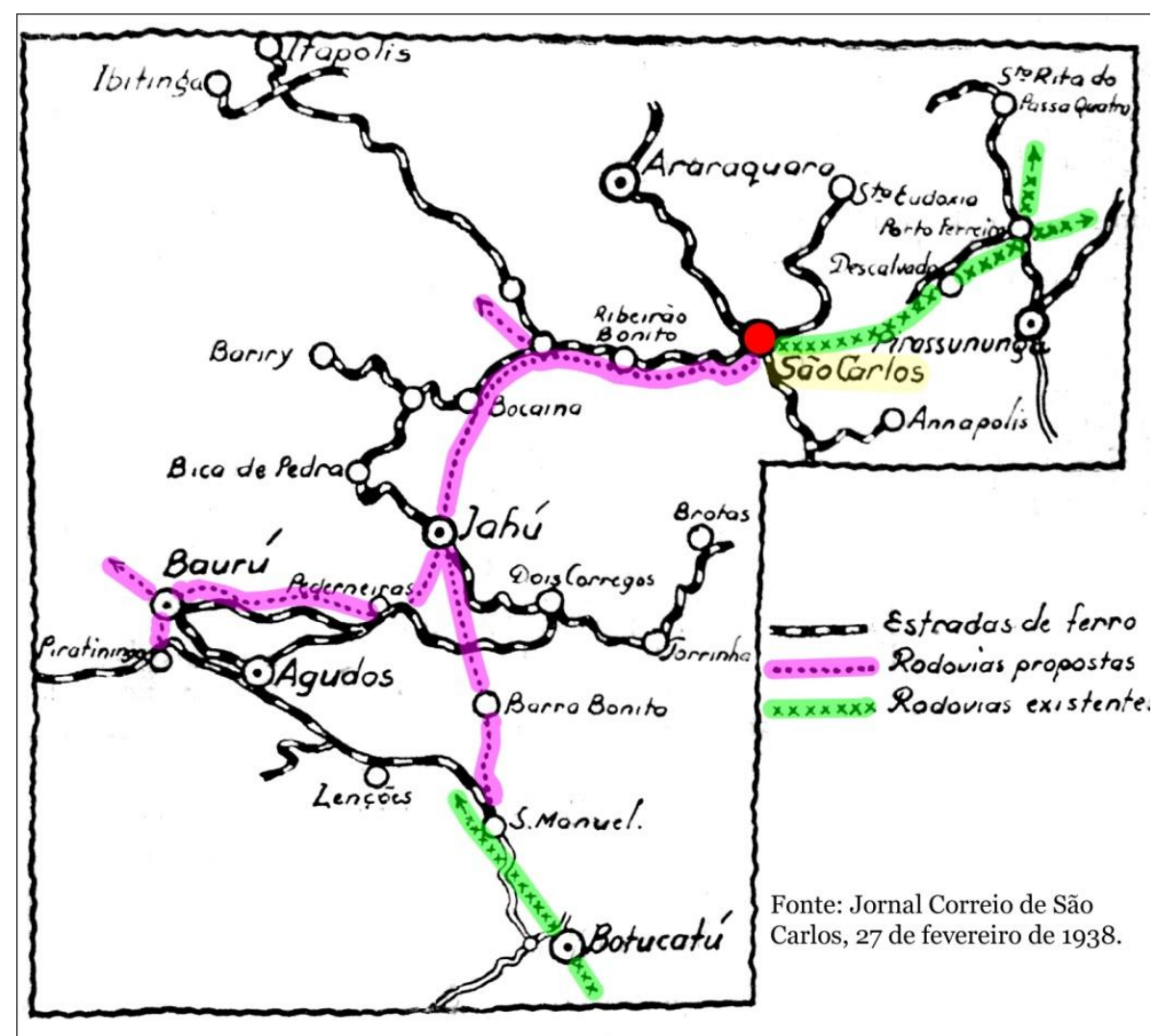

Figura 12: Sistema de transporte na região de São Carlos, 1938.

A figura acima mostra que em 1938 havia apenas a estrada ligando São Carlos a Porto Ferreira, chamada estrada São Carlos-Porto Ferreira, que era o meio de se chegar 
à capital do estado por automóvel, pois, de Porto Ferreira, havia outra estrada fazendo a ligação com São Paulo - atualmente denominada Rodovia Anhanguera (Almanack de São Carlos, 1929). As rodovias propostas nessa figura indicavam a necessidade de ligação de São Carlos com Jaú, e de Jaú para Bauru e Barra Bonita. No entanto, o governo do estado construiu primeiramente a rodovia São Carlos-Araraquara e depois a rodovia São Carlos-Rio Claro, atualmente denominada Rodovia Washington Luís.

Ainda no ano de 1938, o mesmo jornal mostrava propagandas de automóveis e de óleo para automóveis (figuras 13 e 14). Mesmo que o automóvel ainda não fosse um bem popular, o anúncio demonstra a sua inserção e a criação do sistema rodoviário durante a década de 1930.

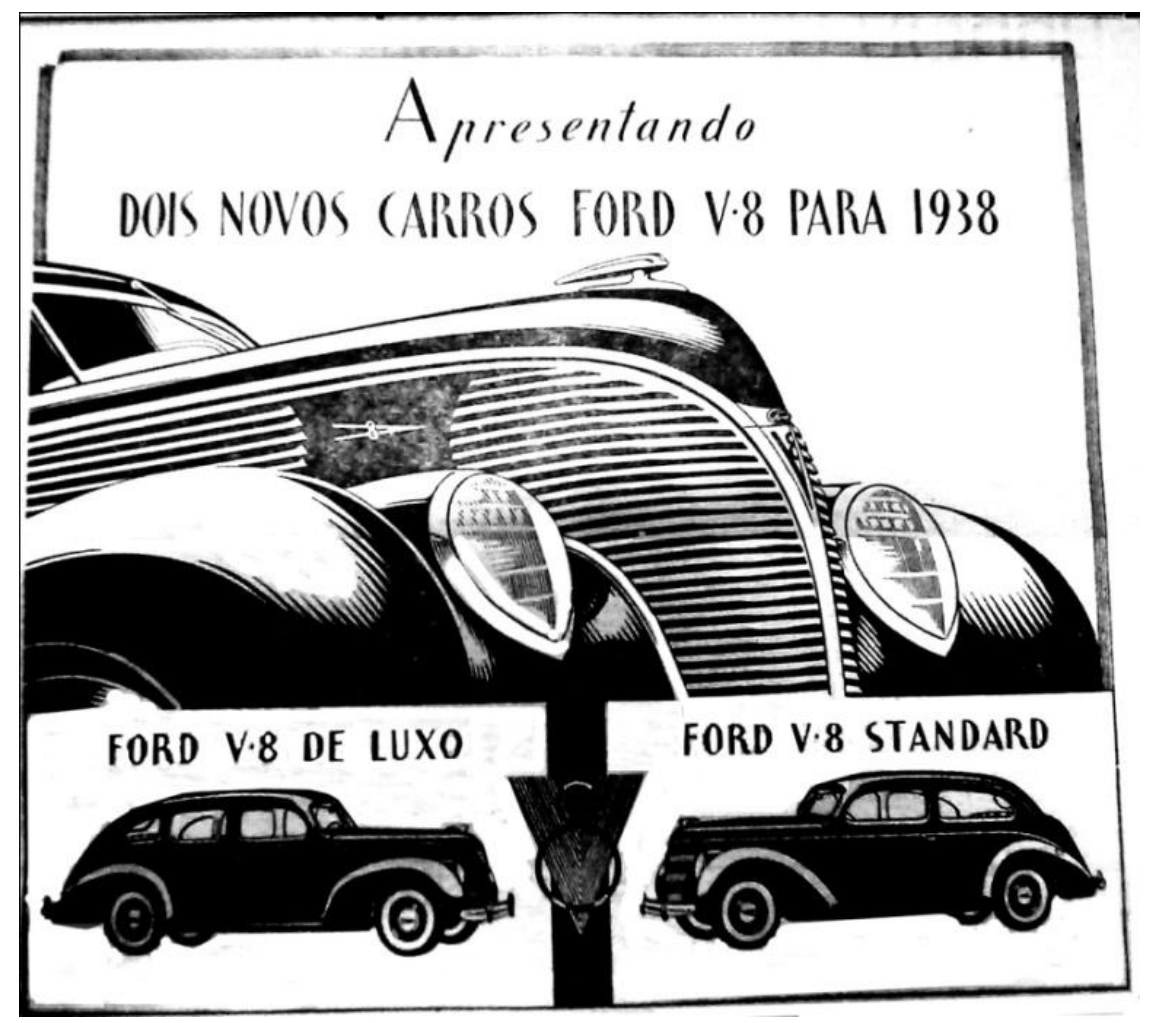

Figura 13: Propaganda de automóvel em 1938.

Fonte: Correio de São Carlos, 30 de janeiro de 1938. 


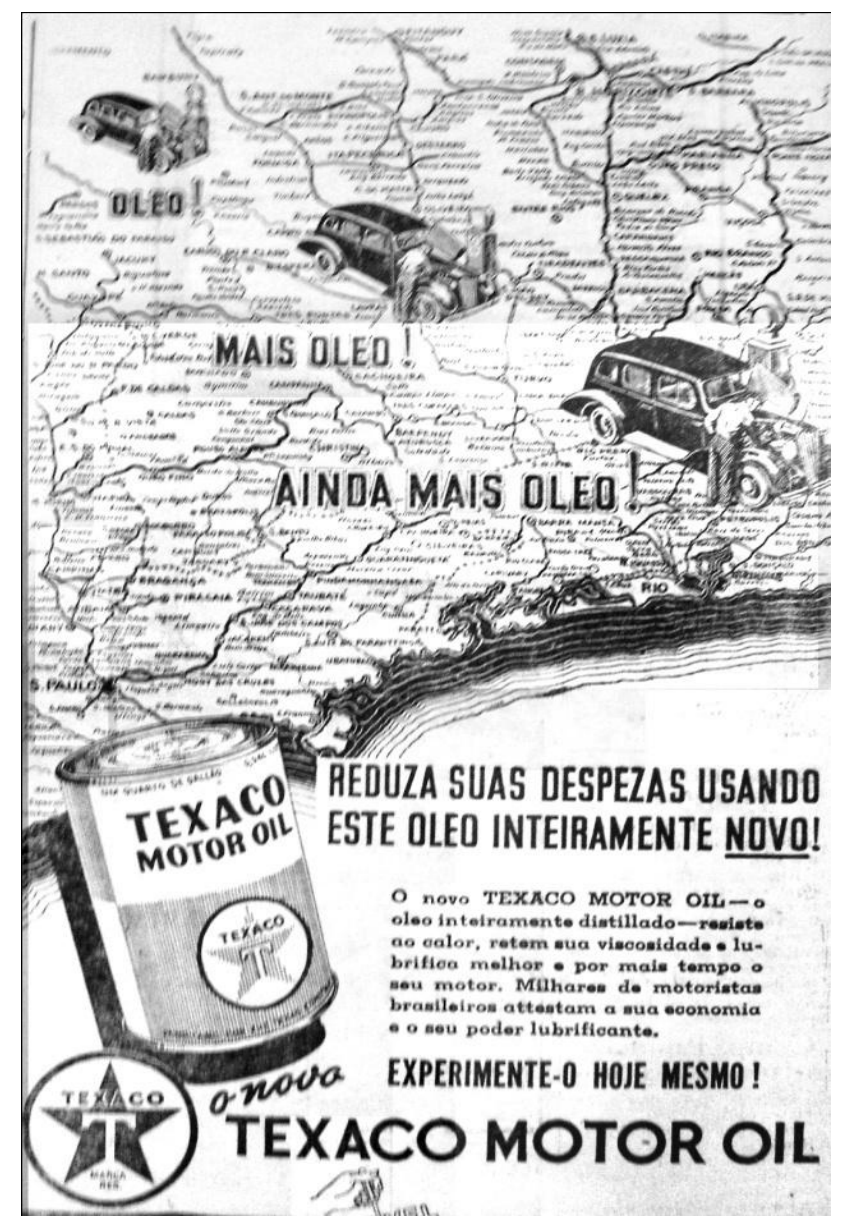

Figura 14: Propaganda de óleo para automóvel em 1938.

Fonte: Correio de São Carlos, 13 de março de 1938.

Em maio de 1943, por decreto estadual, foi declarada de utilidade pública para ser desapropriada pela Fazenda do Estado, uma faixa de terra necessária à construção da rodovia Araraquara-São Carlos (DECRETO N. 13.363, DE 12 DE MAIO DE 1943) e em abril de 1949, foi declarada de utilidade pública, para ser desapropriada pelo Departamento de Estradas de Rodagem (DER), uma faixa de terra necessária à construção da estrada Rio Claro-São Carlos (DECRETO N. 18.566, DE 7 DE ABRIL DE 1949). Essas duas estradas formam parte da atual rodovia Washington Luís.

$\mathrm{Na}$ década de 1950, entrava em funcionamento o tradicional Posto Castelo, localizado no município de São Carlos à margem da estrada São Carlos-Rio Claro. Esse posto foi fundado pelo neto do Conde do Pinhal, Martinho Carlos de Arruda Botelho, que vislumbrou a possibilidade de adquirir terras e empreender um Plaza rodoviário. Assim, em 1957, no ano do centenário de São Carlos, foi fundado o posto e o restaurante Conde do Pinhal, que posteriormente viera a se chamar Posto Castelo, 
devido à construção de um castelo no local, em celebração à origem da família Arruda Botelho $^{13}$. Abaixo as figuras ilustram esse importante estabelecimento de comércio e serviços à margem da rodovia:

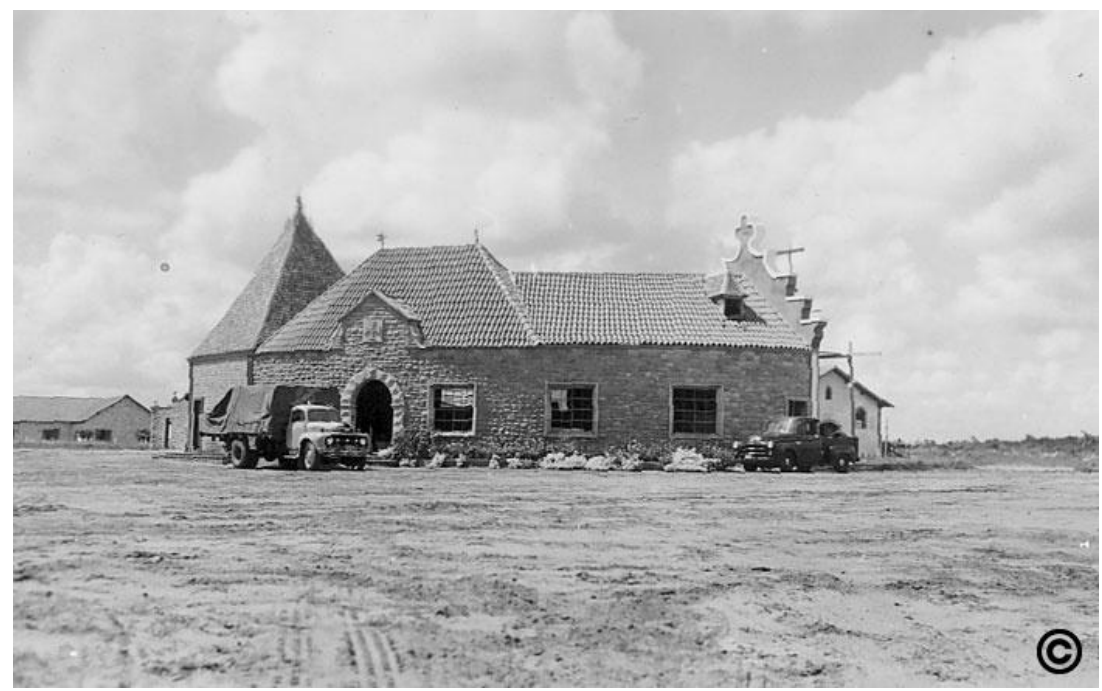

Figura 15: Restaurante Castelo na década de 1950

Fonte: http://www.postocastelo.com.br/fotos-historicas.php

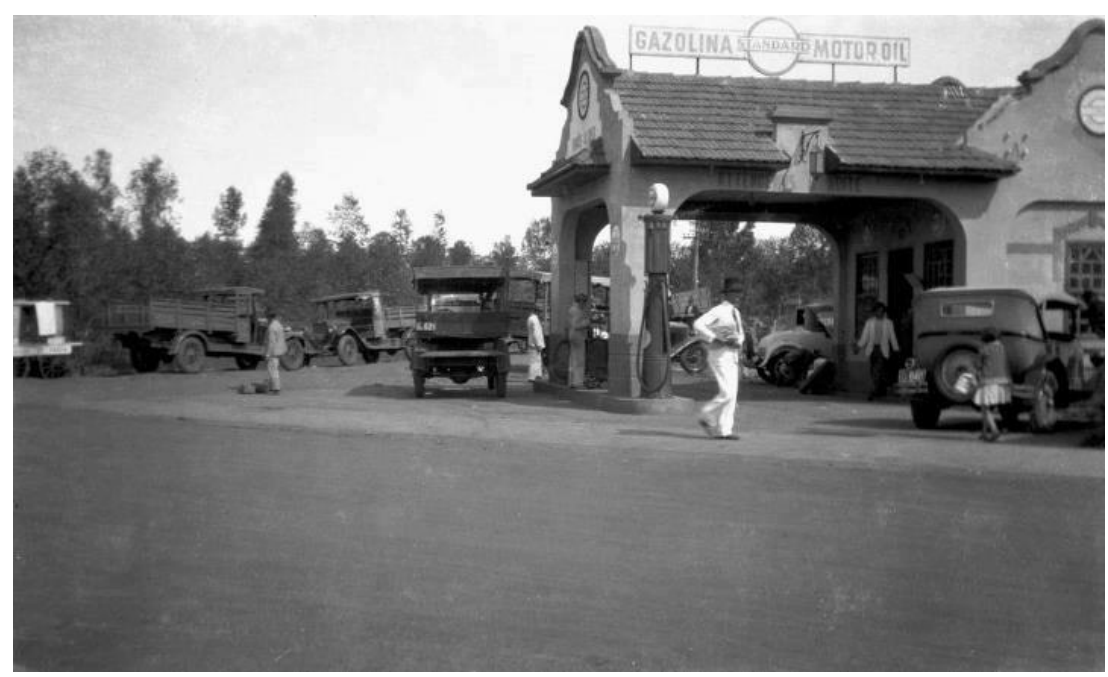

Figura 16: Posto Castelo na década de 1950

Fonte: http://www.postocastelo.com.br/fotos-historicas.php

${ }^{13}$ Disponível em: http://www.postocastelo.com.br/historia.php (acesso em janeiro de 2015) 
Na figura 12, mostramos que em 1938, havia a proposta de construção da estrada entre São Carlos e Bocaina. No ano de 1950, um anúncio do jornal Correio de São Carlos mostrava que essa estrada ainda não havia sido construída, mas que sua construção beneficiaria também os municípios de Jaú, Dourados, Ribeirão Bonito, Trabijú, e Itapuí.

\section{Estradla S. Carlos-Bocaina \\ Resulta de um trabalho incansavel da im. prensa local e do esforç, de varios politicos, in- teressados na construção de uma rodovia moder- na lig indo São Carlos a São João da Bocarna, tanto desta c.d ide como dos municipios que serão cortados ou ating dos direta ou indiretamente por esse traçado, o estulo agora a cargo do Departa- monto de Estradas de Rodagem para determinar as vantagens da mesm; e se a condecendencia topográlica permita se torae esse desiderato uma realidade.}

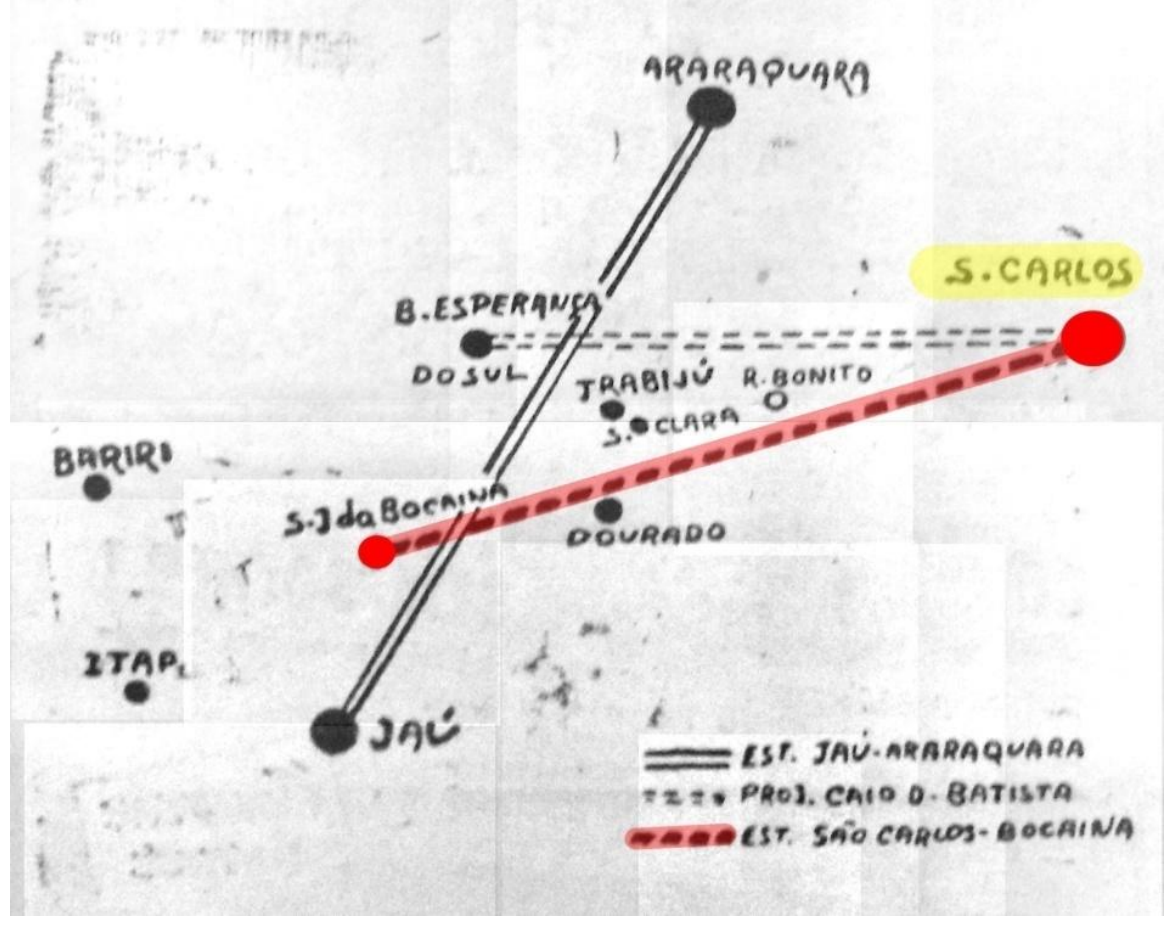

Figura 17: Proposta de estrada entre São Carlos e Bocaina em 1950.

Fonte: Modificado pelo autor com base em: Correio de São Carlos, 25 de maio de 1950 . 
Como conseqüência do desenvolvimento do sistema rodoviário, a partir de 1949, teve início um direcionamento da expansão urbana em São Carlos rumo à rodovia (mapa 11), prenunciando a nova localização da indústria afastada da ferrovia e a mudança na relação moradia-indústria, associadas ao crescimento do número de automóveis e do acelerado crescimento do terceiro setor na economia.

A Lei Municipal no 1456 de 1951 autorizou contratar por meio de concorrência pública, empresa para realizar o serviço de transporte coletivo por meio de ônibus. Assim, no início da década de 1950, começaria a funcionar no município o transporte coletivo urbano por ônibus (CÂMARA MUNICIPAL DE SÃO CARLOS, LEI No 1456 de 1951). A figura abaixo mostra o acesso rodoviário à cidade de São Carlos através da Avenida São Carlos. No canto direito da imagem, vê-se o frigorífico São Carlos do Pinhal S/A, de onde partiam, na década de 1960, quatro linhas de ônibus que ligavam os bairros da região sul de São Carlos, onde se concentrava a população operária do município.

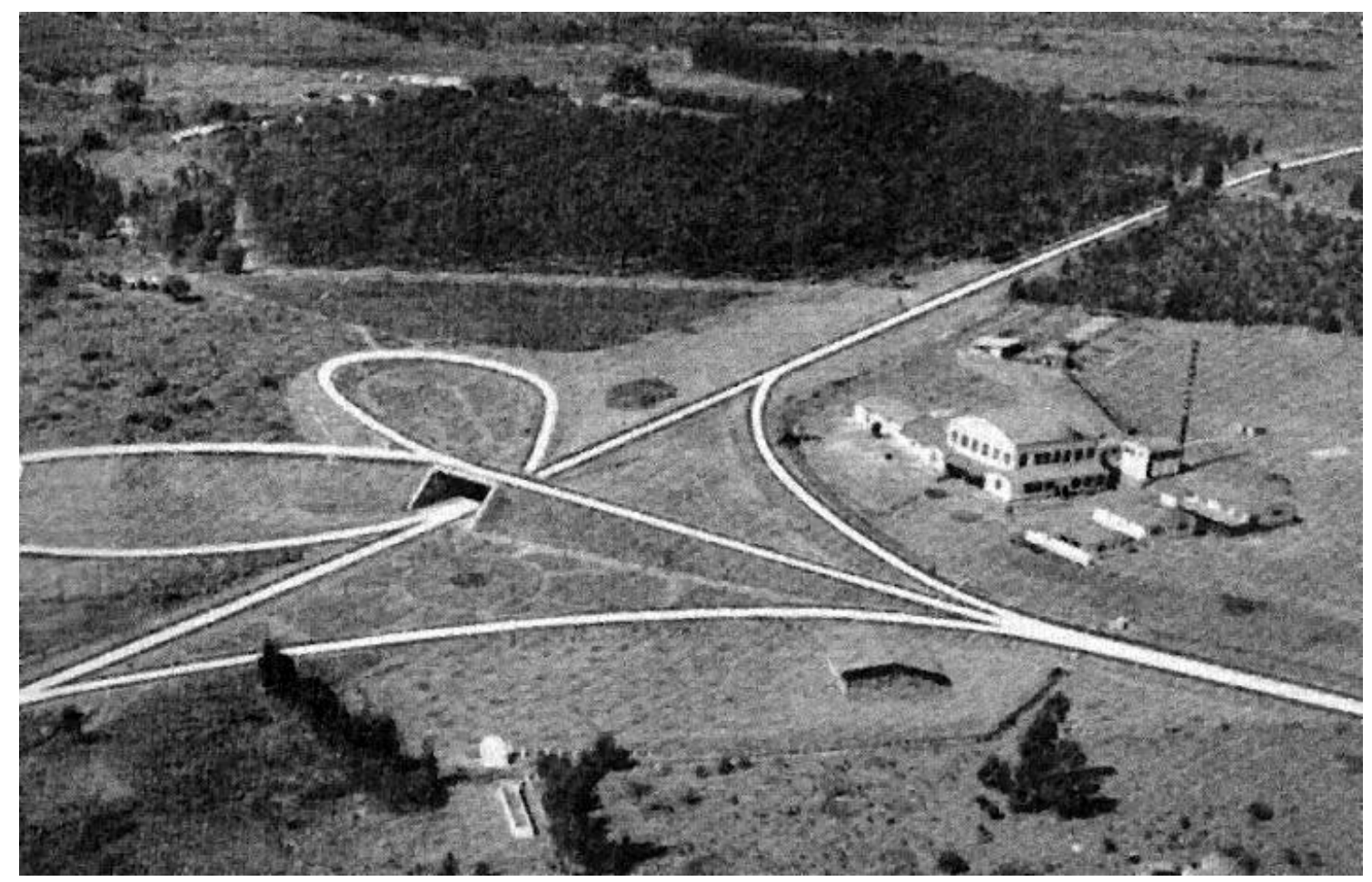

Figura 18: Trevo e frigorífico em São Carlos na década de 1960

Fonte: Prefeitura Municipal de São Carlos. Fundação Pró-Memória 
O processo de industrialização no estado de São Paulo e em São Carlos a partir da década de 1950 foi impulsionado pela produção de bens de consumo duráveis e bens de capital. Em relação à etapa anterior, essas indústrias se diferenciam por possuir uma estrutura produtiva que opera com um índice mais elevado de tecnologia, capitalização e número de empregados. Ao fabricarem produtos com maior valor agregado, tendem a atender um mercado maior e mais diversificado, se aproveitando dos avanços tecnológicos nos meios de transportes. Por necessitarem de um espaço de produção, armazenamento e escoamento da produção amplos, sua localização dentro do sitio urbano tende a ser cada vez mais afastada desse perímetro, seguindo os eixos rodoviários.

Conforme aponta Negri (1996:144), na década de 1950, os investimentos em estradas de rodagem superaram largamente o das ferrovias, sendo que o governo do estado de São Paulo encampou a Cia. Paulista de Estradas de Ferro (empresa que implantou o ramal de São Carlos em 1884), desativando 967 quilômetros de ramais.

"Em 1955, havia em todo o estado de São Paulo um total de 8.980 quilômetros de estradas de rodagem, dos quais 817 quilômetros com pavimentação asfáltica. A partir de então, o Departamento de Estradas de Rodagem (DER) aumentou seu ritmo de obra... Entre 1956/60, são pavimentados quase 5 mil quilômetros de estradas de rodagem em São Paulo, com o que se totaliza 5,9 mil quilômetros asfaltados em 1962, representando $48 \%$ das estradas paulistas... Em 1963, a quilometragem de estradas pavimentadas superaria a das sem pavimentação... Em 1966/67, havia mais de 9 mil quilômetros de estradas pavimentadas, correspondendo a dois terços da extensão da rede, período em que as rodovias radiais são totalmente asfaltadas, juntamente com as transversais mais importantes" (NEGRI, 1966:115).

Portanto, a década de 1950 é o momento de inflexão na lógica territorial, apoiada pelo sistema rodoviário e estimulada economicamente pela industrialização, pela formação de um mercado interno e pelo Plano de Metas (1956-1961) que previa a construção de infraestruturas para dar continuidade ao processo de substituição de importação. Embora a extensa rede ferroviária continuasse a ter um papel importante, o sistema rodoviário ganhava crescente relevância, integrando mercados e áreas de fraco 
povoamento e de difícil acesso, sobretudo locais em que a ferrovia não chegava. Essas mudanças no sistema de transporte de caráter regional, aliadas ao processo de urbanização, constituíram a base para o desenvolvimento da indústria no interior do estado, que, segundo Negri (1996), a partir de 1967, cresceria a taxas superiores à capital e sua região metropolitana.

O desenvolvimento do sistema rodoviário alterou também a conformação do espaço intraurbano em São Carlos. Se durante as décadas de 1930 e 1940, a localização das atividades econômicas no município (indústrias, comércio e serviços) se concentrou próxima à ferrovia e essas atividades atraíram as moradias, a partir do início da década de 1950, a relação espacial entre indústria-transporte e indústria-moradia começou a se alterar, concomitante com a construção das rodovias São Carlos-Araquara e São CarlosRio Claro e com intensificação do sistema de pavimentação urbana. Assim, nas décadas de 1950 e 1960, a localização das indústrias deixou de se concentrar próxima à ferrovia, pois não dependia mais exclusivamente dessa, e os loteamentos passavam a se dispersar pela periferia. Em 1951, começou a funcionar o transporte intraurbano por ônibus, servindo os bairros mais distantes dos locais de trabalho.

A população total do município, de 47.731 habitantes em 1950, passou para 86.385 habitantes no ano de 1970 (aumento de $81 \%$ ). A população urbana passou de $\mathbf{3 2 . 7 0 3}$ habitantes em 1950 para 76.681 em 1970, ou seja, um aumento de $135 \%$ em duas décadas. No ano de 1950, a população urbana correspondia a 68,5\% e no ano de 1970, já havia alcançado $88,8 \%$ da população total do município (IBGE. Censos Demográficos de 1950, 1960, 1970).

A década de 1950 foi também o momento em que se intensificou o crescimento da área loteada, com 43 empreendimentos e uma área total de 751,2 hectares. Em relação às duas décadas anteriores, reduziu-se o número de loteamentos implantados por industriais e os loteamentos se dispersaram seguindo as avenidas que ligam à atual rodovia Washington Luís. Na década de 1960, desacelerou-se a expansão da área loteada, com 415.52 hectares em 14 novos loteamentos, sendo que a participação dos industriais atuantes no parcelamento do solo seguiu diminuindo.

Com todas essas mudanças e com o aumento do número de indústrias, o poder público iniciou uma atuação no final da década de 1950, no sentido de controlar a localização das indústrias, colocando regras ou incentivos para sua instalação. Também foram aprovadas algumas leis relacionadas ao transporte rodoviário. 
Pela Lei n 1360, de 1951, foi criada na Diretoria de Obras da Prefeitura, uma seção especial de estradas e caminhos municipais sob denominação de "Serviço de Estradas de Rodagem Municipal"; a Lei $n^{\circ} 1438$ aprovou um contrato lavrado em 24 de agosto de 1951 para a construção de uma estação rodoviária em terreno do Patrimônio Municipal, celebrado entre Miguel Petroni e a Prefeitura; a Lei no 1456 autorizou contratar por meio de concorrência pública, empresa para realizar o serviço de transporte coletivo por meio de ônibus, para servir aos bairros da cidade (CÂMARA MUNICIPAL DE SÃO CARLOS, LEIS Nº 1360, 1438 e 1456, de 1951).

O mapa 12 mostra a área urbana, as indústrias instaladas e a infraestrutura de transportes no ano de 1965. Percebe-se, em relação ao mapa 10, um crescimento da área loteada e que a ferrovia ainda concentra grande número de indústrias. No entanto, se considerarmos apenas as indústrias fundadas a partir de 1950, veremos que essas passaram a se localizar próximas à rodovia. 


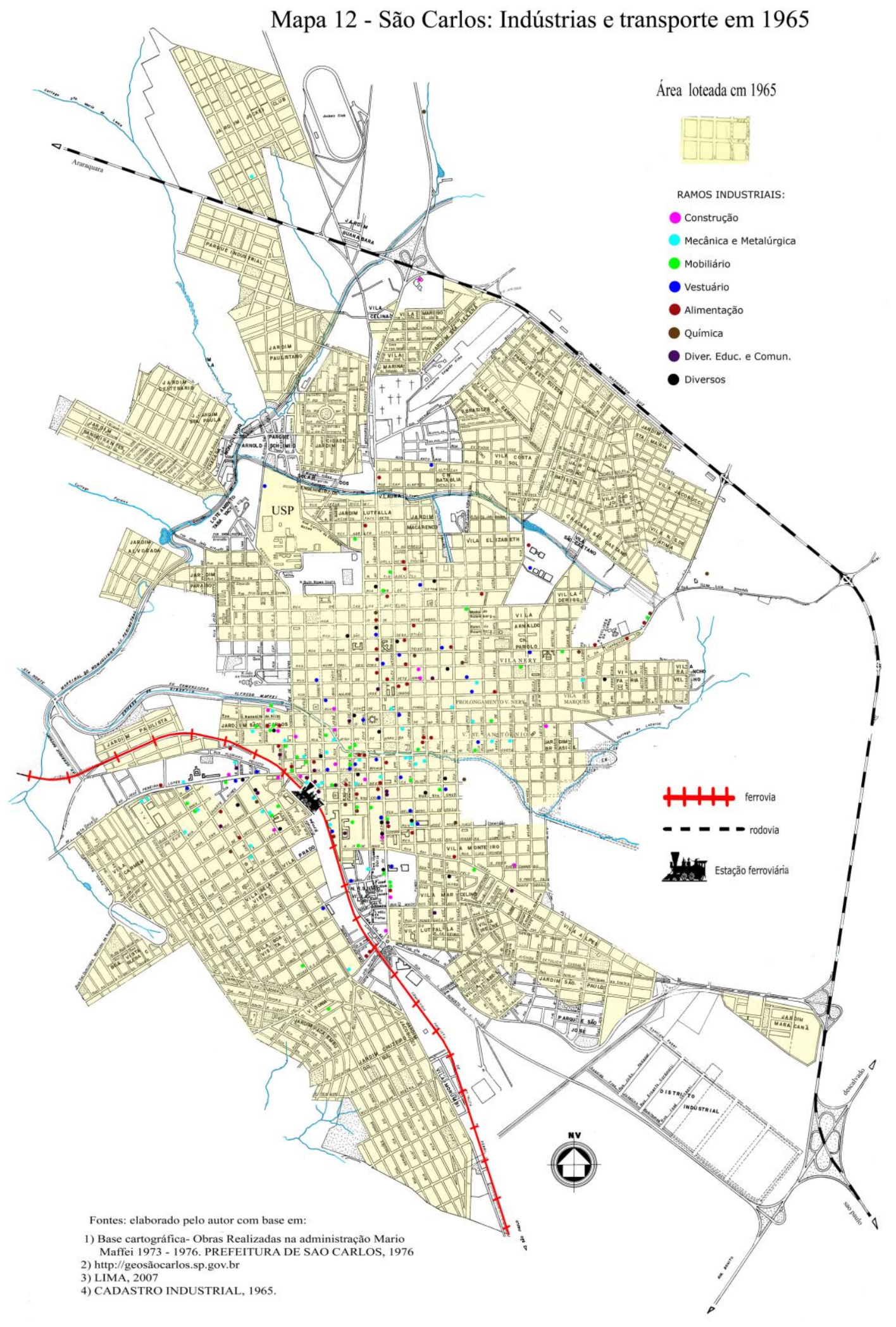


Para mostrar que as indústrias instaladas nas décadas de 1950 e 1960 não se concentravam exclusivamente próximas à ferrovia, consideremos todas que possuíam mais de 20 funcionários no ano de 1965 (33 estabelecimentos), ou seja, aqueles que necessitam de maior aporte de transportes para o escoamento das matérias-primas e dos produtos acabados e atendiam mercados mais distantes. Entre essas 33 indústrias, 16 estabelecimentos foram fundados até 1949 e 17 estabelecimentos entre 1950 e 1965 , (CADASTRO INDUSTRIAL, 1965). Abaixo, listamos as indústrias com mais de 20 funcionários fundadas até 1949. Todas se localizaram próximo à estação ferroviária, na zona sul, como pode ser observado no mapa 13.

\section{INDÚSTRIA ENDEREÇO}

- Indústria Pereira Lopes S/A.................................Av. José Pereira Lopes, 250

- Lápis Johan Faber Indústria..................................Rua José Bonifácio, 420

- Fiação e Tecelagem Germano Fehr.........................Vila Prado, Travessa 8, S/N

- CIA Fiação e Tecidos São Carlos............................Rua Aquidaban, 02

- Ibrahim Remaili e CIA LTDA................................Rua José Bonifácio, 178

- S/A Indústria Giometti..........................................Rua Episcopal, 961

- Cooperativa de Laticínios de São Carlos.................Rua 9 de Julho, 787

- Francisco Ferreira S/A..........................................Rua Vde de Inhaúma, 304

- Ind. de Camas Moraschi S/A...................................Rua 9 de Julho, 1101

- Ind. de Móveis Gelsomino Saia LTDA.....................Rua 13 de Maio, 1084

- Ind. Favoretto LTDA...............................................Av. São Carlos, 468

- Ind. Carlos Facchina S/A.......................................Rua Bento Carlos, S/N

- Antonio F. Crnkovic.................................................... São Carlos, 2810

- Cooperativa Agrícola de São Carlos........................... Cel. Leopoldo Prado, 78

- Gráfica Correio de São Carlos S/A...........................Rua Bento Carlos, 1269

- Willian Sallun e CIA...............................................Av. José Pereira Lopes, 261

Adiante, segue a lista das indústrias que foram fundadas entre 1950 e 1965. Entre essas 17 indústrias, apenas seis se instalaram próximas à estação ferroviária (1Tecelagem São Carlos LTDA, 2-Prominas Brasil S/A, 3-Antoine Azouri e Irmão, 4-Ind. e Com. de Roupas Pinhal S/A, 5-Paço e CIA e 6-J. Ferraz Camargo S/A). As demais se instalaram às margens ou em ruas com fácil acesso à rodovia. Entre essas seis 
indústrias, apenas a Tecelagem São Carlos S/A possuía mais de 100 funcionários, e as demais entre 20 e 49 funcionários, enquanto que as maiores indústrias se instalaram, invariavelmente, próximas à rodovia.

- CIA Brasileira de Tratores .Distrito de Água Vermelha*

- Frigorífico São Carlos do Pinhal S/A Bairro do Monjolinho, S/N

- Fábrica de Tapetes São Carlos LTDA. Rua Miguel Giometti, 340

- Tecelagem São Carlos LTDA Av. São Carlos, 660

- Indústria R. Camargo S/A Av. Luiz Brandão, 85

- Conservas Alimentícias Hero S/A Rua Miguel Giometti, 432

- Cerâmica São José Fazenda Pedrinhas*

- Baptista Lauria Ricetti Ind. E Com. Av. São Carlos S/N

- Diamantul - J K Smit e Sons S/A Jardim Jóquei Club

- Prominas Brasil S/A Aquidaban, 234

- Hece Máquinas e Acessórios Ind. e Com. LTDA....Alfredo Marcondes, 857*

- Ind. de Papel São Carlos S/A Bairro do Monjolinho S/N

- Curtidora Monterrosa LTDA Bairro do Matadouro

- Antoine Azouri e Irmão. São Joaquim, 210

- Ind. e Com. De Roupas Pinhal S/A. Av. José Pereira Lopes, 188

- Paço e CIA. Av. São Carlos, 1028

- J. Ferraz Camargo S/A Rua 9 de Julho, 1269

\footnotetext{
* Indústrias localizadas distantes do perímetro urbano, destaca-se a CBT, instalada no distrito de Água Vermelha.
}

Portanto, o fato mais patente em relação à localização é que as indústrias instaladas nesse período não se localizaram exclusivamente próximas à ferrovia, sendo que as maiores indústrias, invariavelmente, se instalaram próximas aos eixos rodoviários. Outro elemento em relação à localização foi a instalação das indústrias fora do perímetro urbano, conforme mostra a tabela 13. Mostramos que em 1948, $9 \%$ das indústrias se instalaram fora do perímetro urbano e, em 1965, esse número passou para $23 \%$, indicando a mudança na forma de deslocamento do trabalhador para a fábrica. 


\begin{tabular}{|c|c|c|c|c|}
\hline $\begin{array}{l}\text { RAMOS } \\
\text { INDUSTRIAIS* }\end{array}$ & $\begin{array}{c}1948 \\
\text { (unidades) }\end{array}$ & $\begin{array}{c}1948 \\
\text { (percentual) }\end{array}$ & $\begin{array}{c}1965 \\
\text { (unidades) }\end{array}$ & $\begin{array}{c}1965 \\
\text { (percentual) }\end{array}$ \\
\hline Construção & 7 & $33 \%$ & 44 & $58,6 \%$ \\
\hline Alimentação & 3 & $9 \%$ & 14 & $22,2 \%$ \\
\hline Diversos & --- & --- & 6 & $20,6 \%$ \\
\hline Química & --- & --- & 3 & $18,7 \%$ \\
\hline Vestuário & 7 & $9 \%$ & 7 & $15,6 \%$ \\
\hline Metal-Mecânica & --- & --- & 8 & $15 \%$ \\
\hline $\begin{array}{l}\text { Diversão, educ. e } \\
\text { comunicação }\end{array}$ & --- & --- & 3 & $12,5 \%$ \\
\hline Mobiliário & --- & --- & --- & --- \\
\hline TOTAL & 17 & $9 \%$ & 85 & $23,7 \%$ \\
\hline
\end{tabular}

\section{*Ver nota p.75}

Fonte: Cadastro Industrial 1965. Rio de Janeiro: Fibge, 1968.

No mapa 13, mostramos também a relação entre a localização das indústrias e os loteamentos. Fica evidente que a expansão urbana acompanhou o movimento da indústria e do transporte rodoviário, sendo que, em última instância, o transporte induziu a localização das indústrias.

Outro fator que permitiu maior mobilidade espacial na localização das indústrias e das moradias foi a substituição do transporte sobre trilho (bonde) pelo transporte coletivo por ônibus. Conforme vimos, em 1951, foi criada a lei que fez a parceria entre a prefeitura e a iniciativa privada para a construção da rodoviária e a lei para contratação de empresa de ônibus. A rodoviária foi construída em frente à estação ferroviária, onde doravante passou a maioria dos itinerários dos ônibus. Em 1962, o bonde elétrico foi desativado e o transporte coletivo urbano passou a ser exclusivamente por ônibus. A empresa Etracin (figura 19) era responsável por 10 linhas de ônibus no ano de 1969 , como mostra o mapa $13^{14}$.

${ }^{14}$ Foram representados apenas os trajetos de ida dos ônibus. 


\section{Empresa de Transporte}

\section{Coletivo}

\section{Etracin}

Transporte Coletivo Urbano

Onibus modernos

Presteza absoluta no horário

Una garantia nos transportes coletivos de

Sầ Carlos

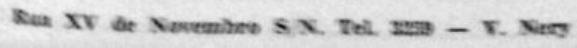

Figura 19: Propaganda de empresa de ônibus

Fonte: SÃO CARLOS: guia de informações, 1969.

A área urbanizada até 1948 era o principal local onde os ônibus circulavam, mas os loteamentos implantados após essa data ficavam distantes do itinerário do ônibus. As indústrias que contavam com maior número de funcionários eram servidas pelos ônibus, a saber, a Indústria Pereira Lopes, o Frigorífico São Carlos, a Tapete São Carlos a Conservas Alimentícias Hero e as demais indústrias da zona sul. Ao final do anúncio dos itinerários dos ônibus lê-se o seguinte:

\footnotetext{
“esses horários citados nos itinerários do ônibus são mantidos rigorosamente. Além das linhas acima citadas e horários, a Empresa coloca carros especiais para os horários das fábricas" (SÃO CARLOS: guia de informações, 1969).
}

A linha chamada "Tapete-Bela Vista", ligando a indústria de tapetes aos bairros Vila Prado e Bela Vista, que abrigavam em quase sua totalidade população operária, demonstra essa relação do ônibus com as indústrias. 
Mapa 13 - São Carlos: Indústrias, bancos, sistema de transporte e área loteada em 1969

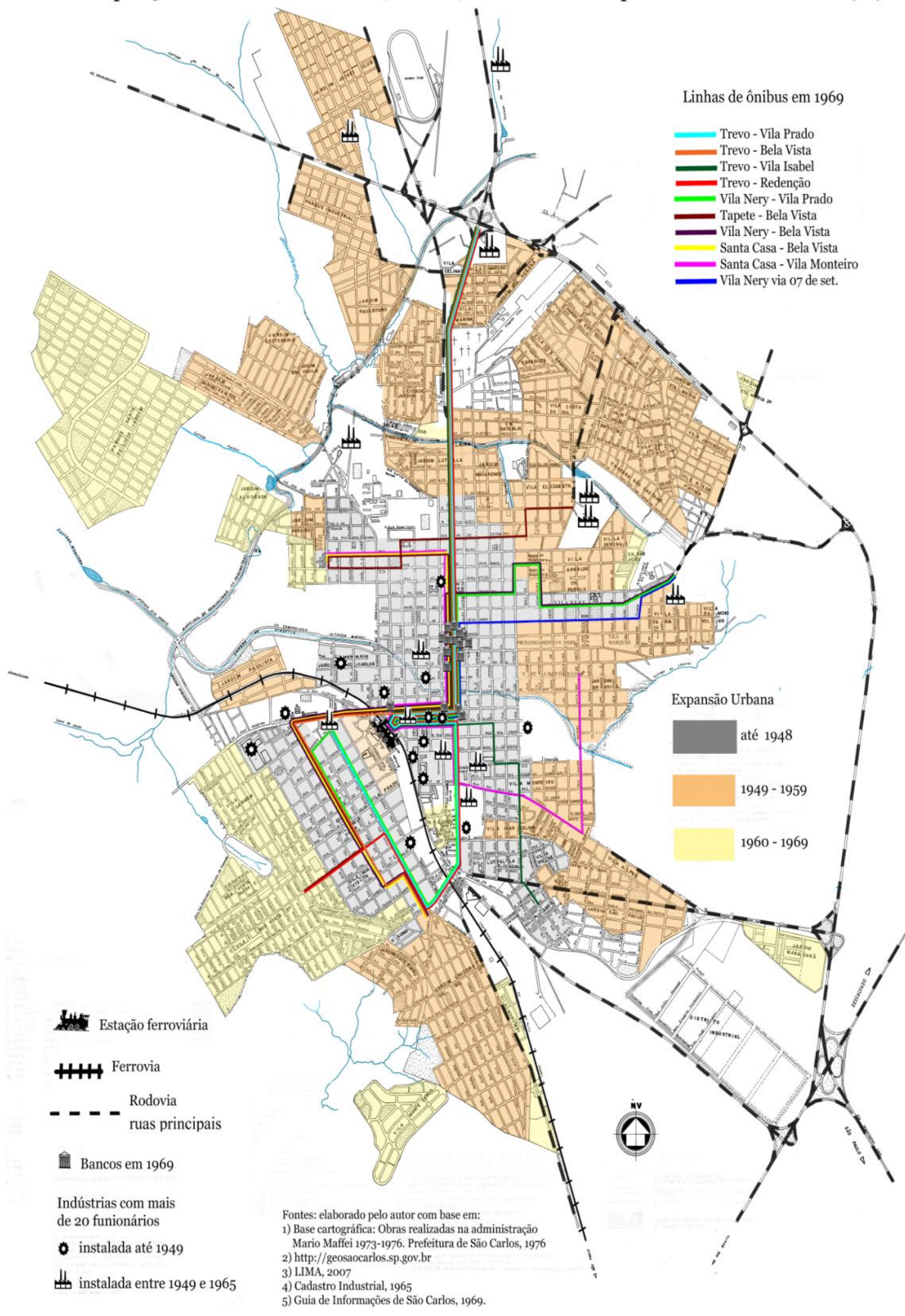


Entre as indústrias representadas no mapa no ano de 1965, a Diamantul - J K Smit e Sons S/A e a Indústria de Papel São Carlos S/A, ambas ao norte, ficavam distantes das linhas de ônibus. As indústrias Cerâmica São José e CIA Brasileira de Tratores não foram mapeadas, pois a primeira se situava na zona rural e a segunda no Distrito de Água Vermelha, no entanto, em entrevista ${ }^{15}$ constatamos que essa empresa possuía ônibus próprios que levavam os funcionários.

\section{7 - A segregação socioespacial em São Carlos nas décadas de 1950 e 1960}

Em seu estudo sobre a segregação socioespacial em São Carlos, Devescovi (1987) estabelece relação da urbanização local com a "questão urbana" no sistema capitalista industrial, na qual as políticas urbanas resultam das necessidades de reprodução da força de trabalho articulados aos investimentos públicos e privados direcionados às diferentes demandas por moradias.

O período objeto desse estudo, no qual analisamos a relação entre industrialização e urbanização, retrata perfeitamente esse processo, sobretudo sobre a análise do (des)controle do poder público sobre a implantação de loteamentos e casas de aluguel destinadas à população de baixa renda, que visava rebaixar os custos com a mão de obra e favorecer a acumulação do capital industrial.

A partir da década de 1930, a expansão urbana se relacionou diretamente aos interesses econômicos da burguesia industrial e comercial, que passaram a investir seu capital no parcelamento do solo urbano, seguros pelo crescente êxodo rural no município. Também se inseriram na política, fato que facilitou a aprovação de loteamentos para atender a demanda de diferentes padrões socioeconômicos. Lima (2007:88) mostra que, até 1929, seguindo os Códigos de Posturas de 1866, 1888 e 1905, os quarteirões ainda mantinham o padrão criado no século XIX, com todas as faces iguais, medindo 90 metros e as ruas tinham de 13 a 14 metros de largura, sendo paralelas e perpendiculares à rua principal, que concentrava atividades urbanas como comércio, bancos, serviços, religião, lazer e moradia da elite. Com a aprovação do Código de Posturas de 1929 e da lei municipal de habitação de 1948 (LEI No 1004/1948), foi aberta a possibilidade de se instalar novos padrões urbanísticos, pois

\footnotetext{
${ }^{15}$ Entrevista concedida por Ítalo Cardinali Filho em 30/06/2014.
} 
ambos tornaram flexíveis os parâmetros urbanos para novos parcelamentos e abriram caminho para uma atuação mais autônoma dos loteadores. Assim, no final da década de 1940, os loteamentos já possuíam lotes menores $\left(300 \mathrm{~m}^{2}\right)$ que na década de 1930 (750 $\mathrm{m}^{2}$ ), mas a prefeitura ainda estabelecia o mínimo de infraestrutura a ser implantada nos loteamentos e que os padrões geométricos dos lotes e ruas fossem mantidos, com ruas retilíneas, ortogonais ou paralelas ao eixo da Avenida São Carlos (LIMA, 2007:90).

A respeito da criação de loteamentos, um artigo ilustra bem como se dava o laissezfaire no ramo imobiliário em São Carlos. Publicado em 1943, no Jornal Correio de São Carlos, lê-se o seguinte:

"São Carlos, como quasi todas as grandes cidades, tem se desenvolvido sem um plano previamente estabelecido. Enquanto que ainda há no perímetro urbano, mesmo no perímetro central, extensas áreas sem edificação, a cidade continua a se "esparramar", como um polvo a extender seus tentáculos. Assim surgiram os nossos inúmeros bairros - Vilas Prado, Neri, Isabel, Pureza, Marcelino, Matias, Municipal, Jardim São Carlos, etc." (Correios de São Carlos, 27 de junho de 1943).

Segundo Abreu (2000), a atuação do poder público local no incentivo aos empreendimentos imobiliários se acentuou após as eleições de 1947, quando industriais e comerciantes passaram a formar a maioria na Câmara Municipal. Para o autor, a partir da segunda metade da década de 1940,

"o incentivo ao desenvolvimento territorial da cidade, que satisfaz a necessidade de moradia e de mão de obra do setor industrial ou facilita o acesso ao local de trabalho, é encarado pelo conjunto da sociedade municipal como uma atitude moderna. Ser moderno é fazer a cidade crescer, é oferecer incentivos para o principal setor da economia... essa concepção de poder levou os poderes públicos da cidade de São Carlos a promover a expansão territorial do município. Primeiro, loteando as áreas de sua propriedade na região central da cidade, depois, dividindo com os loteadores os custos sociais de suas atividades imobiliárias" (ABREU, 2000:114). 
Ao longo das décadas de 1950 e 1960, com a intensificação do processo de industrialização e a influência dos eixos rodoviários e pavimentação urbana, dois fatores relativos às moradias se destacaram: a localização afastada do centro e a concentração da população por renda. Além do novo direcionamento da expansão urbana, a partir do final da década de 1940, prenunciava-se também a mudança no padrão urbanístico que ocorreria nas décadas seguintes. A acelerada expansão de loteamentos na década de 1950 intensificou a concentração por classe. Enquanto que na Vila Elizabeth e Vila Pureza se concentravam famílias de alta renda, que deixavam o centro devido ao aumento do comércio, a Vila São José e a Vila Leonardo (ambos localizados à margem da rodovia), e os bairros da zona sul foram ocupados por famílias de baixa renda.

Abaixo segue uma propaganda do loteamento Vila Faria, lançado em 1949. Esse bairro localizava-se distante da estação e das indústrias da zona sul, seguindo a rua Padre Teixeira, pela qual passava o bonde. Embora tenha sido aprovado em 1949, esse empreendimento foi efetivamente construído na década de 1950 e retrata a mudança de localização que ocorre neste período. A Vila Faria era uma extensão (ver mapa 13) da Vila Nery, que era habitada por moradores de classe média (conforme apontado anteriormente). Pela localização e infraestrutura percebe-se que não era destinada à classe de baixa renda.

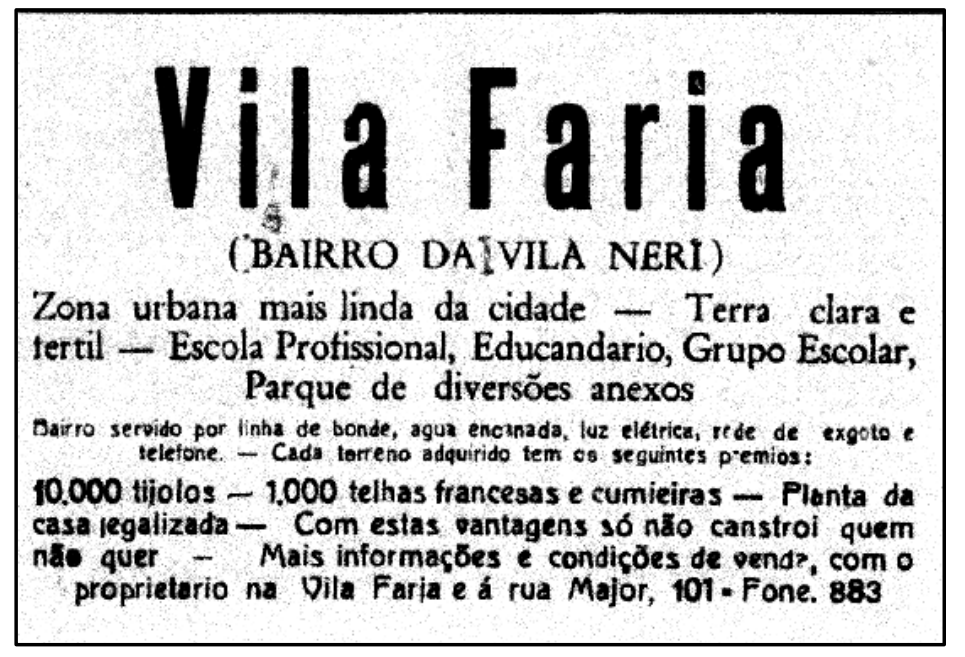

Figura 20: Propaganda do loteamento Vila Faria.

Fonte: Jornal Correio de São Carlos, 08 de Junho de 1950 
No dia 12 de fevereiro de 1955, o jornal denunciava o problema de abastecimento de água nas casas dos bairros Vila Monteiro e Vila Prado, tendo os moradores que buscar água com baldes nas torneiras das ruas. No bairro Vila Puresa, a água não era encanada, existindo um fossa que exalava, segundo a matéria, uma fedentina horrível, originando verdadeiros exércitos de moscas e pernilongos, perturbando os moradores dia e noite e ameaçando a saúde pública (Correio de São Carlos, 12 de fevereiro de 1955).

O loteamento Cruzeiro do Sul, implantado em 1954 pela Imobiliária Lutfalla, que era de propriedade de empresários do ramo têxtil, foi a marca da periferização e precarização das infraestruturas mínimas necessárias para o aprovação de loteamentos. Segundo Lima (2007:93), apesar de o projeto inicial aprovado pela Prefeitura prever uma área de lazer, no Jardim Cruzeiro do Sul foram implantados 1.605 lotes sem uma única área verde. Do mesmo modo ocorreu em loteamentos menores, como na Vila Alpes (1950), Vila Celina (1951), Chácara Bataglia (1955), Vila Derigge (1956) e Jardim Bandeirantes (1958). Nesses empreendimentos, havia precariedade de infraestruturas, os lotes eram bem menores $\left(300 \mathrm{~m}^{2}\right)$ que o padrão tradicional $\left(750 \mathrm{~m}^{2}\right) \mathrm{e}$ as ruas secundárias eram estreitas, enquanto as vias de trânsito rápido e avenidas eram mais largas, marcando a influência do automóvel na construção da espaço (LIMA, 2007).

A grande expansão urbana ocorrida na década de 1950 foi acompanhada da atuação especuladora no mercado imobiliário. O prefeito Antonio Massei, visando controlar a especulação imobiliária na área central, em 16 de fevereiro de 1955, explica para a população, através do jornal Correio de São Carlos, as razões do aumento de impostos na área central da cidade. Segundo o prefeito, além do aumento dos gastos públicos devido ao surgimento de novos loteamentos, aumento do preço dos materiais destinados a melhoramentos públicos da ordem de $500 \%$ em doze anos e aumento do salário mínimo, o poder público convivia com a ação de especuladores que adquiriram lotes vazios em áreas dotadas de todos os melhoramentos públicos. Ainda afirma que esses proprietários pagavam impostos insignificantes, e não desejavam vender ou construir nesses lotes, visando maior valorização dos terrenos. Por isso, relata, tornou-se necessário aumentar o imposto predial, a taxa de limpeza e a taxa de água. Além disso, tendo em vista o aumento de assaltos e visando melhorar a segurança pública investindo na Guarda Noturna Municipal, foram acrescidos $2 \%$ sobre o valor locativo dos prédios, 
o que era suficiente para investir na guarda municipal (Correio de São Carlos, 16 de fevereiro de 1955).

Em 1960, um anúncio de jornal relatava os problemas decorrentes da atuação de agentes privados no mercado imobiliário e da falta de controle e planejamento do poder público:

"Não obstante São Carlos ter nascido planejada, sofreu há 20 anos a esta parte uma deturpação urbanística verdadeiramente contrastadora. $\mathrm{O}$ bairros que foram aparecendo como um milagre das mil e uma noites, fugiram por completo ao traçados antigos de ruas largas e retas, para dar lugar às ruas estreitas e sinuosas, como se realmente sofrêssemos crise de terreno[...]" (Correio de São Carlos, 25 de agosto de 1960, apud ABREU, 2000:81)

O mapa 13 mostra que as condições de acessibilidade/mobilidade pioraram em loteamentos periféricos como Vila Boa Vista, Jardim Cruzeiro do Sul, Jardim Pacaembu, Vila Monte Carlo, Jardim Maracanã, etc., (localizados na zona sul), e em loteamentos como Parque Santa Felícia, Parque Industrial, Jardim Jóquei Clube, Vila São José, Vila Jacobucci, etc., (localizados na zona norte), pois os ônibus não circulavam nesses lugares, dando prioridade para ligar as indústrias com os bairros onde tradicionalmente se concentravam a população operária (Vila Prado, Vila Bela Vista, Vila Monteiro, Vila Isabel e Vila Lutfalla). Os ônibus circulavam também no centro e nos bairros Vila Puresa e Vila Nery, ou seja, onde se concentravam o comércio e serviços e a população de classe média.

Com a implantação da USP, surgiram bairros de classe média destinados à população de melhor qualificação profissional, sobretudo aos professores. Um desses bairros foi o Cidade Jardim, um loteamento implantado em 1954 próximo à USP (figura 21). Em relação aos aspectos urbanísticos, esse loteamento guarda semelhança apenas no nome com a Garden Citie de Ebenezer Howard.

O loteamento implantado em São Carlos com o nome de 'Cidade Jardim', com apenas 33 hectares de área, foi um projeto de loteamento, assim como outros do mesmo período, que segue a racionalidade do melhor aproveitamento do espaço visando maior quantidade de lotes. Seu diferencial foi a localização estratégica, próximo às infraestruturas de transportes (bonde, ônibus e acesso à rodovia). 


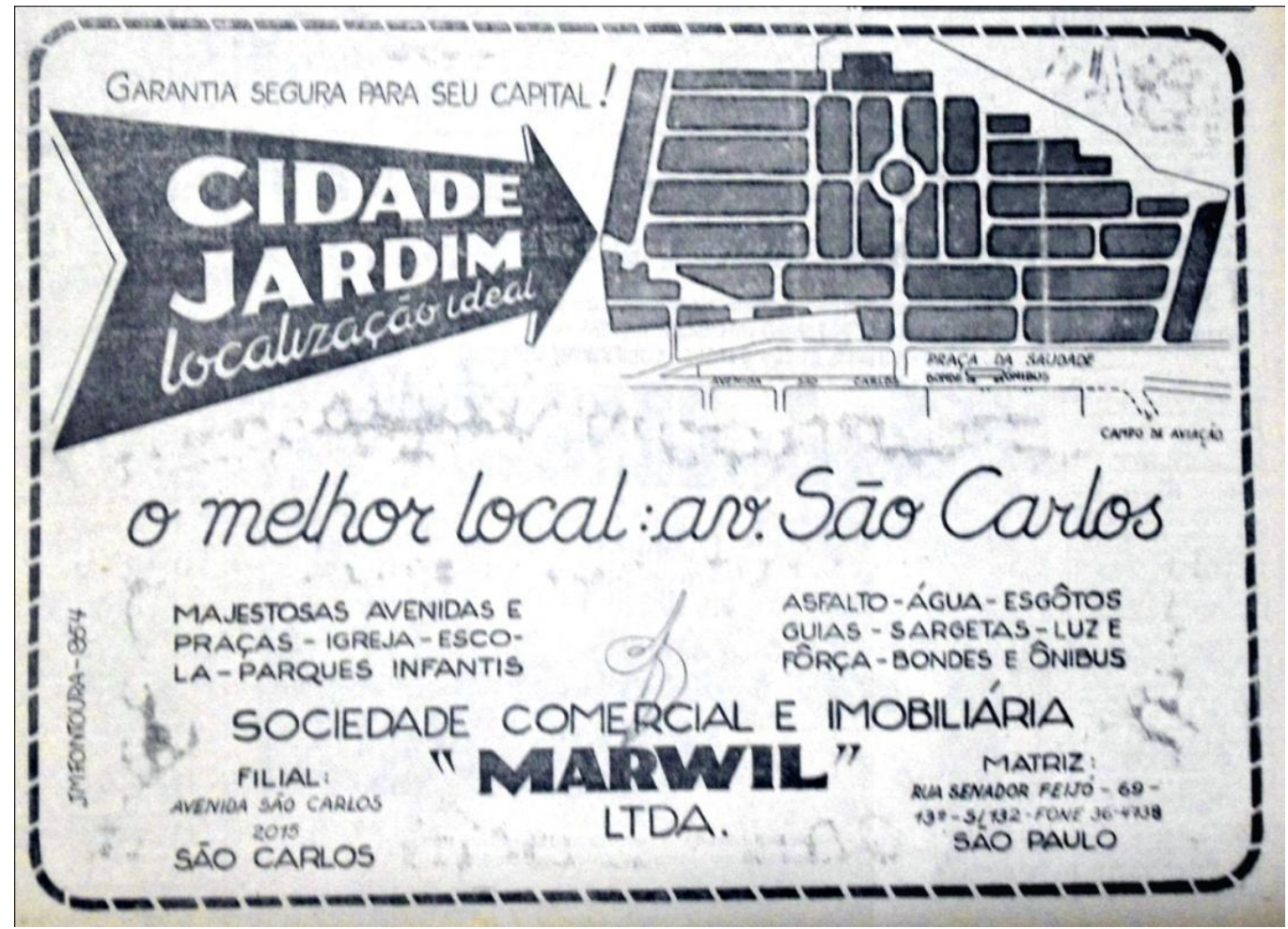

Figura 21: Desenho do loteamento Cidade Jardim: São Carlos, 1954

Fonte: Correio de São Carlos, 10 de junho de 1954

No entanto, em uma matéria de 20 de fevereiro de 1954 do jornal Correio de São Carlo, na qual se lê em letras garrafais "Cidade Jardim - Satélite de São Carlos", com claro objetivo de fazer propaganda do loteamento, explica que o empreendimento (realizado pela Sociedade de Investimentos Imobiliários MARWIL ltda, com sede na cidade de São Paulo e filial instalada na Av. São Carlos), difere completamente dos outros, uma vez que a empresa não só promove a venda dos lotes, como também executa todas as obras de urbanismo e edificação dos prédios. Abaixo transcrevemos parte da entrevista que o jornal realizou com um dos sócios da MARWIL.

"O nosso loteamento conta de início com todos os melhoramentos públicos, como: água própria com instalação de poços artesianos, esgoto, sarjetas, guias, pavimentação a asfalto, etc. O loteamento foi traçado dentro dos mais modernos planos urbanísticos obedecendo em tudo a Codificação das Normas Sanitárias. Esses melhoramentos já foram acatados e estão sendo executados pela Sociedade Industrial 
Urbanizadora e Pavimentadora 'Ubiratan' S/A, com sede em São Paulo. Felizmente, tivemos dos poderes públicos de São Carlos o mais louvável apoio no que diz respeito ao loteamento Cidade Jardim. Aliás, não se trata, como foi dito, de um LOTEAMENTO DE TERRENO, mas da abertura de uma nova cidade-satélite de São Carlos" (sic) [Correio de São Carlos, 20 de fevereiro de 1954].

O anúncio continua, mostrando os procedimentos de compra dos lotes, indicando ainda alguns benefícios de se morar nesse bairro, como a proibição de instalação de indústrias ruidosas ou poluidoras da atmosfera e instalação de ampla rede de comércio, como farmácias, mercearias de luxo, restaurantes e casas comerciais de todos os gêneros.

Também foram implantados loteamentos melhor localizados e com infraestruturas adequadas, destinados à população de classe média e alta do município. Em entrevista ${ }^{16}$ com empresário do ramo imobiliário de São Carlos constatamos que os bairros de classe alta eram a Estância Suíça (1957) com 36,20 hectares e Parque Santa Mônica I (1966) com 8,76 hectares.

Em 1959, foi aprovada a lei n 3907, que criou a Comissão do Plano Diretor, a qual deveria entregar à Câmara, no prazo de dois anos, um Plano Diretor para São Carlos. No ano de 1960, foi criado por decreto municipal o Escritório Técnico do Plano Diretor de São Carlos, como órgão assessor do Plano Diretor (LIMA, 2007).

Em entrevista realizada no Escritório Técnico do Plano Diretor com o arquiteto coordenador do plano, Dr. Alberto Carlos, o jornal são-carlense "A Cidade" (A Cidade, São Carlos, 27 de janeiro de 1962) obteve-se algumas informações sobre o Plano Diretor. Segundo o Dr. Alberto, o Escritório não se restringia ao plano em si, realizando obras paralelas ao planejamento, porém a principal função era o planejamento meticuloso. Para isso, realizavam levantamento de todos os serviços públicos: sistema viário, pavimentação, guias e sarjetas, canais de água e esgoto, escoamento de águas pluviais, redes telefônicas, iluminação pública, coleta de lixo e arborização. Além de levantamento sobre os loteamentos, cálculo de densidade demográfica e outros estudos referentes à zona urbana. Informa ainda que através do plano foram encaminhadas para a Câmara Municipal proposições referentes à atualização do perímetro urbano, uma

\footnotetext{
${ }^{16}$ Entrevista concedida por Ítalo Cardinali Filho em 30/06/2014.
} 
proposição para o estabelecimento de nova zona de expansão urbana e o projeto de lei sobre loteamentos.

Havia também, segundo o coordenador, o contato do escritório técnico com o Centro de Estudos Urbanísticos da Faculdade de Arquitetura da USP São Paulo, onde estava sendo elaborado um Código de Obras que serviria de modelo para todas as cidades do interior do estado.

Amador (1981) aponta que, como o espaço urbano apresentava-se estruturado não havia necessidades de grandes investimentos. No ano de 1960, entre os 9.803 prédios urbanos existentes em São Carlos, 8.664 eram servidos de água e 5.793 de esgoto. O Plano Diretor do Município de São Carlos foi concluído em 1962 e sua principal meta era planejar a cidade futura para até 140 mil habitantes, limitando a zona urbana, zoneando e prevendo o sistema viário para proporcionar o maior equilíbrio das funções de habitação, trabalho, recreação e circulação. (SÃO CARLOS, Plano Diretor do Município de São Carlos, 1962).

No ano de 1962, foram aprovadas duas leis importantes que incidiam sobre o espaço urbano: a Lei de loteamento $n^{\circ} 4411$, que representou um marco no controle da expansão urbana no município. Até a aprovação dessa lei, as exigências que definiam o padrão urbano eram as referentes ao Código de Postura de 1929. Apesar de algumas definições da nova lei serem contrárias às da expansão urbana controlada (LIMA, 2007:146), com a lei de loteamento, foram estabelecidas diversas exigências que impediam uma atuação irresponsável por parte dos loteadores (CÂMARA MUNICIPAL DE SÃO CARLOS, LEI No 4411 de 30 de março de 1962); a outra foi a Lei $\mathrm{n}^{\circ}$ 4421, que dispunha sobre a zona de expansão urbana prevista para o planejamento territorial urbano (CÂMARA MUNICIPAL DE SÃO CARLOS, LEI No 4421 de 25 de abril de 1962).

Ao analisar a atuação da Comissão do Plano Diretor, Amador (1981:44) supõe que sua vida efêmera ocorreu devido às pressões externas a Comissão, pois a racionalização da administração para organizar o ambiente urbano não foi intenção dos grupos dominantes, principalmente dos loteadores. Fato que forçou essa pressão externa foi a constituição da Comissão, na qual a classe mais populosa e mais carente de melhorias na qualidade de vida possuía apenas um representante, enquanto que a elite possuía pelo menos três garantidos. Outro ponto salientado por Amador é que a comissão não fazia parte do quadro administrativo, sendo que sua função era de assessoria indireta ao prefeito, ou seja, tinha a função de órgão consultivo. 
Portanto, nas décadas de 1950 e 1960, a segregação socioespacial foi acentuada em São Carlos. Dois fatores contribuíram para isso: i) a mobilidade urbana propiciada pelos ônibus e automóveis, que permitiu que os trabalhadores tivessem suas moradias distantes do local de trabalho; ii) a flexibilização da legislação permitindo a implantação de loteamentos com lotes menores e carentes de infraestruturas, permitindo a expansão urbana rápida e descontrolada, segregando espacialmente a população por renda. 
CAPÍTUlO 03 - AGENTES PÚblicos E PRIVAdOS NOS PROCESSOS DE INDUSTRIALIZAÇÃO E URBANIZAÇÃO 


\section{1 - Atuação do Estado no processo de industrialização nas décadas de 1930 a 1960}

Durante a década de 1930, os latifundiários começaram a ceder espaço político para a classe que encarnava o novo modo de produção que entrava em cena com o desenvolvimento do capitalismo no Brasil: os industriais. No entanto, como os capitalistas industriais ainda não tinham maturidade para o exercício da hegemonia política, cabia ao "sócio mais velho" (os latifundiários) produzir os líderes que promoveriam a industrialização. Getúlio Vargas, proveniente de uma tradicional família da zona rural na fronteira com a Argentina, foi o exemplo mais acabado dessa liderança (Rangel 1985:26). A política de Estado no contexto do acelerado crescimento industrial e urbano manteve presente os interesses oligárquicos e agroexportadores dos latifundiários, aliados aos interesses de acumulação da burguesia industrial. O campesinato, explorado e ignorante, permaneceu excluído da participação política e os setores populares urbanos (operários, prestadores de serviços, etc.) foram progressivamente ampliando sua representação. Essa é a característica da "revolução burguesa pelo alto" que ocorreu no Brasil em 1930 e deram o tom da política econômico-social nas décadas seguintes (DE DECCA, 1981).

Após 1930, o Governo atuou a favor do processo de industrialização, adotando medidas como resposta à crise que se iniciou em 1929 nos EUA, o principal comprador do café brasileiro. Pelo lado estritamente econômico, Furtado (2008) destaca a depreciação da moeda brasileira para salvar a cafeicultura e as dificuldades impostas às importações, que, por fim, induziram à recuperação da crise pelo setor industrial. Segundo Cano (2002:85), as medidas econômicas tomadas pelo Estado consistiram na desvalorização do câmbio, suspensão do pagamento do serviço da dívida, instituição de controles cambiais drásticos e elevação das tarifas de importação. Baer (1977:17) aponta também que a sustentação da renda do setor cafeeiro conservou no mesmo nível a demanda de bens importados. Essa situação de oferta reduzida e demanda inalterada criou incentivos para aumentar a produção interna das indústrias brasileiras que competiam com as importações. Como o aumento da produção industrial não podia se efetivar através da importação de máquinas, pelo fato de a economia mundial estar em recessão - o que necessariamente induz à depressão dos nossos produtos de exportação relativamente aos preços dos produtos que os países de economias avançadas nos 
exportam -, a fase inicial do crescimento industrial na década de 1930 se caracterizou pela maior utilização da capacidade ociosa das indústrias.

O governo cuidou também de defender a propriedade intelectual brasileira. Em 1933, a Diretoria Geral da Propriedade Industrial ganhou o status de Departamento e novas funções. O Decreto-lei no 22.989 criou o Departamento Nacional da Propriedade Industrial, DNPI. Como atribuições principais do novo órgão, ficaram estabelecidas:

\footnotetext{
“a concessão de patentes de invenção, de melhoramento, de modelo de utilidade, de desenho ou modelo industrial e garantia de prioridade; o registro de marcas de indústrias e de comércio, nome de estabelecimentos, insígnias e emblemas; repressão, dentro da esfera de suas atribuições, da concorrência desleal;" (ABAPI, 1998:32).
}

Segundo Draibe (2004:56), o novo Estado que emergiu em 1930 efetuou uma crescente burocratização e racionalização dos aparelhos do Estado centralizados pelo Executivo Federal. Além de enfraquecer os instrumentos locais e regionais de poder, a centralização trouxe elementos que alteraram a natureza do conjunto de instrumentos políticos e os procedimentos sujeitaram-se crescentemente à lógica racional-legal. A modernização do aparelho do Estado ganharia impulso com o processo de promulgação da Constituição de 1934, no qual foi instituído o Código Eleitoral Brasileiro de 1932, ampliando a participação popular no pleito eleitoral, o que resultou na escolha dos deputados proporcionalmente à população dos estados. Além dos deputados, a Constituinte contou com a presença de representantes escolhidos por entidades sindicais, como sindicato dos trabalhadores, delegados dos empregadores, profissionais liberais e funcionários públicos. $\mathrm{Na}$ nova constituição foram incorporadas como propostas, os direitos trabalhistas (FAUSTO, 1995).

A racionalização administrativa fica evidente com a criação do Conselho Federal do Serviço Público Civil em 1936, que foi sucedido pelo Departamento Administrativo do Serviço Público (Dasp) em 1938. Cabia ao Dasp definir, racionalizar e controlar a carreira do funcionalismo público e a organização administrativa, mas sua ação foi limitada e incapaz de impedir o favoritismo político e o clientelismo (DRAIBE, 2004).

Além de práticas protecionistas, com a formação de numerosa classe trabalhadora nas cidades, reivindicando seus direitos trabalhistas e melhor qualidade de vida, a Questão Social atingiu contornos problemáticos, em especial para a burguesia 
industrial, que passou a se articular com o governo federal para viabilizar novas relações de trabalho. Segundo Fausto (1986:108), durante a década de 1930, o Estado manteve o papel de desorganizador político da classe operária que vinha se organizando nas duas primeiras décadas do século XX, principalmente no Rio de Janeiro e em São Paulo. Devido à organização em massa dos trabalhadores, o Estado reprimiu duramente os partidos operários, ao mesmo tempo em que procurava estabelecer com o conjunto da classe um novo tipo de relação.

Nesse sentido, Oliveira (1987) aponta que o Estado, como representante das emergentes burguesias industrial e comercial, exerceu a importante função de regulador do mercado de trabalho industrial nascente e determinou o preço da força de trabalho, usando o populismo como estratégia para se unir a classe trabalhadora urbana e liquidar politicamente as antigas classes proprietárias rurais. Essa estratégia política começou por estabelecer, também no que diz respeito à organização político-jurídica, a aliança entre o arcaico e o novo, fundando novas formas de relação entre capital e trabalho, a fim de criar as fontes internas de acumulação.

O ponto alto do populismo foi durante o Estado Novo (1937 e 1945), quando o governo aboliu o parlamento (1937), reprimiu os oposicionistas com apoio do exército e controlou a imprensa, através da criação do Departamento de Imprensa e Propaganda (DIP) em 1939, que era diretamente subordinado à Presidência da República. A CLT, editada por Vargas em 1943 (DECRETO-LEI N. ${ }^{\circ}$ 5.452, DE $1^{\circ}$ DE MAIO DE 1943), embora desse licitude à organização sindical, atrelava essas organizações ao Ministério do Trabalho, como forma de controlar os movimentos de interesse econômico e profissional dos trabalhadores.

Segundo Oliveira (1987), ao determinar o preço da força de trabalho através da institucionalização da CLT, equalizando as diferenças de valores para o patamar mais baixo, os industriais, através da estrutura político-jurídica do país, puderam manter os salários reais em um nível baixo e, assim, extrair altas taxas de mais-valia, o que favoreceu o processo de acumulação e novos investimentos em indústrias. Para Rangel (1978:54), na ausência da CLT, a exploração da força de trabalho resultante da livre barganha culminaria em salários ainda mais baixos, além de a legislação colocar outros benefícios aos trabalhadores. No entanto, há um consenso de que a taxa de exploração permanecia elevada.

Um estudo de 1937 do Internacional Labour Office (apud DEAN, 1991:164), concordava que, em parte, o êxito da indústria paulista se explicava pelos baixos 
salários. Devido às extenuantes jornadas de trabalho no início da industrialização paulista, era comum aos operários preferirem descansar a receber salários adicionais num ponto logo acima do limiar da subsistência, tendo os empresários que promover a imigração para reduzir a conseqüente 'escassez de mão de obra'. Vale lembrar que em 'O Capital', lê-se que o valor mínimo da força de trabalho é o valor dos meios de subsistência necessários à conservação de seu possuidor (MARX, 1982). Dean (1991) destaca ainda a face perversa do paternalismo na indústria paulista com que eram tratados os operários, ao mostrar que o mínimo de serviços adicionais, quando fornecidos pelos industriais (v.g., creches, igrejas, restaurantes, habitação, assistências médicas, escolas etc.), eram deduzidos das folhas de pagamentos dos operários.

Com o fim do Estado Novo formaram-se três partidos principais: União Democrática Nacional (UDN), Partido Social Democrático (PSD) e Partido Trabalhista Brasileiro (PTB). Segundo Carvalho (2007:153), os três grandes partidos da Terceira República (1945-1964), PSD, UDN e PTB, no momento em que precisavam atrair as massas,

$$
\begin{aligned}
& \text { "em vez de se limitarem aos grupos de elite, à liderança do governo } \\
& \text { estadonovista se garantiu no processo de democratização via PSD, ao } \\
& \text { passo que a UDN incorporou justamente as lideranças oposicionistas } \\
& \text { nos estados. Tanto esse como àquele eram detentores de amplas bases } \\
& \text { rurais. O PTB, por sua vez, também organizado pela máquina } \\
& \text { administrativa do Estado Novo, incorpora a clientela urbana sindical } \\
& \text { corporativa". }
\end{aligned}
$$

Assim, no processo de redemocratização, a elite do antigo governo totalitário manteve-se no executivo federal via PSD, PTB e via PSP. A estratégia dos partidos consistiu em lograr a simpatia das massas para obter o voto e chegar ao poder, incorporando os interesses populares ao discurso conservador que representavam (CARVALHO, 2007).

Devido ao seu forte apelo popular, em 1945, Vargas elegeu para presidente o militar Eurico G. Dutra do PSD. Após mais um mandato de Vargas como presidente (1952-1954), assumiu o vice Café Filho, filiado ao Partido Social Progressista (PSP), fundado por Ademar P. de Barros. O PSD chegaria ao poder novamente com Juscelino Kubitschek. Na década de 1960, Jânio Quadros chegou à presidência pelo Partido Trabalhista Nacional, formado por dissidentes do PTB, mas, com sua renúncia, o PTB 
assumiu novamente com João Goulart, até 31 de março de 1964, quando os militares chegaram ao poder.

Entre as décadas de 1940 e 1960, no governo do estado de São Paulo destacou-se a trajetória de Ademar Pereira de Barros, aliado político de Vargas. Descendente de uma tradicional família de cafeicultores, foi eleito deputado estadual de São Paulo pela Constituinte de 1934. Durante o Estado Novo foi nomeado interventor federal e, em 1947, foi eleito para o cargo de governador do estado de São Paulo. De 1963 até 1966, Ademar P. de Barros cumpriria seu segundo mandato como governador, até ser cassado pelos militares. Com o fim do seu primeiro mandato como governador eleito, elegeu seu sucessor, o engenheiro Lucas Nogueira Garcês, ambos pertencentes ao PSP fundado por Ademar P. de Barros ${ }^{17}$. Sucederam no governo do estado, Jânio Quadros e Carvalho Pinto, ambos formados em direito e ligados à direita paulista, pelo PSD e pelo Partido Democrata Cristão (PDC), respectivamente (COELHO, 2003). Após o golpe militar, a ARENA assumiu o governo em 1967 com Laudo Natel. A tabela abaixo mostra os presidentes e os governadores de São Paulo e os partidos aos quais pertenciam, entre 1948 e 1969.

Tabela 14: Presidentes e governadores de São Paulo e filiação partidária - 1948 a 1969

\begin{tabular}{|c|c|c|c|c|c|}
\hline CARGO & $1948-1951$ & $1952-1955$ & $1956-1959$ & $1960-1963$ & $1964-1969$ \\
\hline Presidente & $\begin{array}{l}\text { Eurico Gaspar } \\
\text { Dutra (PSD) / } \\
\text { Getúlio Vargas } \\
\text { (PTB) }\end{array}$ & $\begin{array}{l}\text { Getúlio Vargas } \\
\text { (PTB) / Café } \\
\text { Filho (PSP) }\end{array}$ & $\begin{array}{l}\text { Juscelino } \\
\text { Kubitschek (PSD) }\end{array}$ & $\begin{array}{l}\text { JK (PSD) / } \\
\text { Jânio Quadros } \\
\text { (UDN) / João } \\
\text { Goulart (PTB) }\end{array}$ & $\begin{array}{l}\text { João Goulart } \\
\text { (PTB)/ Castelo } \\
\text { Branco/ Costa e } \\
\text { Silva (ARENA) }\end{array}$ \\
\hline $\begin{array}{l}\text { Governa- } \\
\text { dor }\end{array}$ & $\begin{array}{l}\text { Ademar Pereira } \\
\text { de Barros (PSP) } \\
\text { /Lucas Nogueira } \\
\text { Garcês (PSP) }\end{array}$ & $\begin{array}{l}\text { Lucas Nogueira } \\
\text { Garcês (PSP) / } \\
\text { Jânio Quadros } \\
\text { (PTN) }\end{array}$ & $\begin{array}{l}\text { Jânio Quadros } \\
\text { (PTN) / Carvalho } \\
\text { Pinto (PDC) }\end{array}$ & $\begin{array}{l}\text { Carvalho Pinto } \\
\text { (PDC)/ Ademar } \\
\text { Pereira de } \\
\text { Barros (PSP) }\end{array}$ & $\begin{array}{c}\text { Ademar Pereira } \\
\text { de Barros (PSP) } \\
\text { Laudo Natel/ } \\
\text { Roberto de A. } \\
\text { Sodré (ARENA) }\end{array}$ \\
\hline
\end{tabular}

Fontes: Elaborado pelo autor com base em: RAMOS, 1980; Abril S.A. Cultural. Nosso Século, 1985.

\footnotetext{
${ }^{17}$ Disponível: http://www.academiapaulistadeletras.org.br (acesso em janeiro de 2015)
} 
No caso paulista, todos os partidos foram cúmplices do golpe por apoiarem as políticas de exceção anteriores a ele e por apoiarem a ditadura em troca de cargos políticos. Com a redemocratização, formaram-se três partidos principais: União Democrática Nacional (UDN), Partido Social Democrático (PSD) e Partido Trabalhista Brasileiro (PTB). A extinta UDB de Armando S. de Oliveira serviu de modelo para a formação da antigetulista UDN. O plantel do extinto PRP (oligarquia agrária) foi quase todo para o PSD, que se tornou aliado ao PTB fundado por Vargas, que mantinha base eleitoral com o operariado urbano e ligação com os sindicatos (RAMOS, 1980).

Ao analisar a preferência do voto operário, Simão (1956) aponta que, em 1933, o número de eleitores no estado de São Paulo era de 299.074, passando para 1.565.248 eleitores em 1948, aumento esse ocasionado, segundo o autor, pelo crescimento demográfico, diminuição do analfabetismo e pelo decreto de Vargas de 1932 que instituiu o Código Eleitoral. Na eleição para o legislativo e o executivo estadual de 1947, os eleitores operários do estado de São Paulo compunham 24,92\% dos votos do estado, $36,62 \%$ na capital e $18,18 \%$ no interior. Em áreas da capital onde $40 \%$ dos eleitores eram operários, o Partido Trabalhista Brasileiro (PTB) obteve 19,5\% dos votos e o Partido Comunista do Brasil (PCB) 15,56\%. Assim, os partidos considerados de centro-esquerda somaram $35,06 \%$ de votos entre os operários, enquanto que a direita representada por PSP, UDN, PSD e PDC somou 66,19\% de votos, fato que ficou conhecido como "populismo de direita" no estado de São Paulo. Considerando o fenômeno do populismo como uma variável histórica com base de classe, e não apenas um fenômeno de manipulação eleitoral, Simão (1956) mostra que as aspirações das baixas camadas médias encontraram expressão no conservadorismo, na defesa da "moral" e dos bons costumes e na construção de um Estado autoritário, traços típicos do discurso dos partidos de direita.

A década de 1950 foi o período de grande crescimento industrial, atuação do Estado na economia e de entrada do capital estrangeiro na indústria. No ano de 1951, foi criada a Comissão Mista Brasil-Estados Unidos para o Desenvolvimento Econômico, na qual as políticas de elevação dos níveis de vida foram definidas menos nos termos da justa distribuição da riqueza e do produto nacional do que do desenvolvimento econômico. Acreditava-se que havia muito pouco que se dividir, por isso, preconizava-se uma política de bem-estar social apoiada no alicerce da economia do país. No contexto da Guerra Fria, os governos brasileiros acreditavam que o sucesso da economia e da 
elevação do nível de vida de parte da sociedade era a arma mais eficaz na luta contra o comunismo. Essa era a concepção de governo do segundo mandato de Getúlio Vargas e que permeou a visão de governo dos futuros presidentes, pelo menos até o final da Ditadura Militar ${ }^{18}$.

A Comissão Mista acabou aprovando 41 projetos do Plano de Reaparelhamento Econômico elaborado pelo governo, os quais foram financiados pelos governos federal e estaduais, pelo Banco Interamericano de Reconstrução e Desenvolvimento (BIRD) ou pelo Export-Import Bank. Do investimento total, 60,6\% deveriam ser alocados no setor de transportes, $33,1 \%$ no setor de energia elétrica e $6,3 \%$ em projetos relativos à indústria, máquinas agrícolas e estocagem de cereais. Como resultado do trabalho da Comissão, ficou estabelecido que seria criado o Banco Nacional de Desenvolvimento Econômico (BNDE). Em 1952, foi sancionada a Lei $n^{\circ} 1.628$, que criou o BNDE, que tinha por objetivo formular e executar a política nacional de desenvolvimento econômico. Numa primeira fase, o BNDE investiu em infraestrutura, mas com a criação de empresas estatais, aos poucos, o Banco passou a investir mais na iniciativa privada e na indústria ${ }^{19}$. Em relação à produção energética, em 1953, foi sancionada a Lei Federal $n^{\circ} 2004$ que estabeleceu o monopólio da União na exploração, produção, refino e transporte do petróleo no Brasil, criando a Petrobras. Em 1954, o Governo propôs a criação da Centrais Elétricas Brasileiras, que só foi aprovado por Jânio Quadros em 1960, pela Lei 3.890-A, autorizando a construção da Eletrobras, que ocorreria somente em 1962.

O Plano de Metas lançado no governo de Juscelino Kubitschek tinha por objetivo eliminar os pontos de estrangulamento da economia por meio de investimentos estatais em infraestruturas, principalmente em produção de energia e transporte rodoviário, e expandir o setor de indústria pesada, como indústria automobilística e de material elétrico, incentivando investimentos privados nacionais e estrangeiros através da criação de condições econômica, financeira e sociais adequadas (Ianni, 1991:163).

Como consequiência do plano, no período de 1957-1961, o PIB cresceu 7,9\% a.a. e o setor de transportes, 8,8\%. Apesar da entrada de empresas estrangeiras, entre $1956 \mathrm{e}$ 1960, a renda das empresas governamentais cresceu acima da economia nacional e a

${ }^{18}$ Disponível em: http://cpdoc.fgv.br (acesso em janeiro de 2015).

${ }^{19}$ Disponível em: http://cpdoc.fgv.br (acesso em janeiro de 2015). 
participação da renda gerada por essas empresas nos setores de indústria, bancos e transportes passou de 7,5\% em 1956 para 9,9\% em 1960 (IANNI, 1991:167). Assim, quem deixou de ganhar com o novo imperialismo foi a burguesia industrial brasileira.

Nas décadas de 1930 e 1940, as indústrias privadas nacionais cresceram em função do mercado interno com apoio do Estado, que assumiu o protagonismo do processo. Com o fim do ciclo de substituição de importações e o início do processo de industrialização pesada, a partir de meados da década de 1950, as empresas estrangeiras foram atraídas pelo governo brasileiro, elevando o nível socioeconômico do país, mas principalmente, trazendo o know-how de que o Brasil necessitava para adentrar em novo ciclo de crescimento do capitalismo industrial e financeiro. O papel do Estado consistiu em investir em infraestrutura e financiamento para o setor privado nacional e estrangeiro. Embora houvesse regras que limitassem a entrada das empresas de fora, nesse processo de abertura a burguesia industrial brasileira inevitavelmente diminuiu sua parcela de participação do PIB nacional. Nas palavras de Octavio Ianni (1991:183),

\footnotetext{
“o Programa de Metas implicou numa mudança qualitativa na figura e nos papéis do Estado. De fato, esse programa implicou na adoção de uma política econômica de associação e interdependência, de âmbito internacional. Isso significava que os governantes optaram por uma estratégia política de desenvolvimento econômico que trazia consigo, como componente essencial, a reelaboração da dependência estrutural, que sempre caracterizou a economia brasileira. E significava, ainda, que a intervenção estatal na Economia deixara de inspirar-se na idéia de emancipação ou autonomia"
}

Segundo Pereira (1974), a burguesia industrial brasileira perdeu a oportunidade de ser nacional e independente, na medida que, com sua ascensão consolidada, foi incapaz de desenvolver uma ideologia própria, aliando-se à oligarquia dependente e alienada e aceitando uma posição de dependência do governo que adotava práticas protecionistas. No final da década de 1950, não fizeram resistência à abertura econômica e preferiram se aliar ao capital internacional, pois isso significava, de um lado, concorrência, mas de outro, a possibilidade de cooperação na qualidade de fornecedores e compradores de empresas estrangeiras, aceitando uma posição secundária ao reservar setores para a indústria estrangeira. 


\begin{abstract}
"Renovava-se, assim, a aliança entre o capitalismo internacional e o brasileiro. Os parceiros, porém haviam mudado e os objetivos também eram algo diversos. A velha aliança fora estabelecida entre a oligarquia agrário-comercial mercantilista e o capitalismo internacional, em função da divisão internacional do trabalho e do modelo primário-exportador. Corresponde ao velho imperialismo, que limita-se a organizar a produção e a comercialização dos produtos primários, e se opõe ao desenvolvimento industrial. A nova aliança é estabelecida entre o capitalismo brasileiro moderno inclusive os empresários industriais e o capitalismo internacional, com a participação do governo como parte essencial da aliança. Corresponde ao novo imperialismo, que não é mais anti-industrializante, mas que propõe um modelo de desenvolvimento industrial dependente muito particular para o Brasil (PEREIRA, 1974:19)"
\end{abstract}

Nos governos de Jânio Quadros e João Goulart, a economia enfrentava séria crise inflacionária e diminuição da entrada de capital externo. Politicamente, havia um antagonismo entre o Legislativo, formado em grande parte por representantes do setor agrário, e o Executivo, que adotara o industrialismo como sinônimo de progresso e o agrarismo como estagnação, fato que agravava a crise conjuntural. Para Ianni (1997), nem Jânio, nem Jango estavam preparados para resolver a herança dos governos anteriores, pois não conseguiram elaborar um sistema de diretrizes coerentes para resolver os problemas econômicos, representados por baixo crescimento do PIB e crescente inflação. A direita conservadora se apropriou da conjuntura fragilizada e, em aliança com os interesses imperialistas, uma parte do legislativo e do exército promoveram o golpe militar de 1964.

Durante o regime autoritário na década de 1960, foram elaborados o Programa de Ação Econômica do Governo (1964-1966), o Plano Decenal de Desenvolvimento e o Programa Estratégico de Desenvolvimento. Em termos de governança, os Atos Institucionais garantiram uma estrutura política adequada para atingir os objetivos do governo. Como resultado para o processo de industrialização na década de 1960, o governo militar reduziu o ritmo da inflação, criou a Embraer - Empresa Brasileira de Aeronáutica S.A -, e o Banco Nacional da Habitação (BNH), que impulsionou a indústria da construção. 
Com a abertura da economia para as indústrias estrangeiras iniciada com o Plano de Metas e continuada no governo militar, no ano de 1968, alguns setores da indústria eram quase que totalmente controlados por empresas estrangeiras, com destaque para a produção de automóveis, cigarros, produtos elétricos, medicamentos e máquinas para indústria e agricultura. A tabela abaixo mostra em quais ramos o capital estrangeiro ocupava maior parcela da produção industrial no ano de 1968.

\begin{tabular}{|l|c|}
\hline \multicolumn{2}{|l|}{$\begin{array}{l}\text { Tabela 15: Produção das indústrias estrangeiras em } \\
\text { relação ao total da produção industrial de origem } \\
\text { privada em 1968 }\end{array}$} \\
\hline \multicolumn{1}{|c|}{ INDÚSTRIA } & PRODUÇÃO \\
\hline Automobilística & $90 \%$ \\
\hline Cigarros & $85 \%$ \\
\hline Eletricidade & $82 \%$ \\
\hline Farmacêutica & $70 \%$ \\
\hline Máquinas & $70 \%$ \\
\hline Química & $50 \%$ \\
\hline Plásticos & $45 \%$ \\
\hline Autopeças & $35 \%$ \\
\hline Cimento & $20 \%$ \\
\hline
\end{tabular}

Fonte: Boletim Cambial, de 23 a 30/10/1968 apud Rattner, 1972.

\section{2 - Industriais na política em São Carlos}

A estrutura política do município de São Carlos acompanhou o movimento nacional no período em que se desencadeou o crescimento industrial e urbano no município, durante as décadas de 1930 e 1940, tanto no que tange à composição dos agentes do poder público como na forma de atuação. Ao longo das décadas de 1950 e 1960, as indústrias de grande porte se instalaram no município e o processo de urbanização se acelerou, sendo que a representação política da burguesia agrária foi definitivamente suplantada pelos interesses dos industriais e da classe média urbana (pequena burguesia comercial e profissionais liberais). 
Nos anos de 1936 e 1947, foram realizadas as eleições municipais em todo território nacional, ou seja, antes e depois do Estado Novo. A partir do levantamento dos vereadores e prefeitos no município de São Carlos, mostraremos as mudanças que ocorreram em relação à representação das classes sociais na política, a saber, ocaso da elite agrária e ascensão dos industriais e da classe média urbana.

Percebe-se que as mudanças na representação política durante as décadas de 1930 e 1940 foram drásticas, pois a estrutura agrária e política no município de São Carlos se arrastava desde o Império e Primeira República (PREFEITURA MUNICIAPAL DE SÃO CARLOS, Galeria do Prefeitos, 2012). A República não conseguiu estruturar partidos nacionais e, em São Paulo, a oligarquia se organizou em torno do Partido Republicano Paulista (PRP). A luta política são-carlense no início do século XX se dava entre duas famílias de fazendeiros de café, a família Salles e a família Botelho. Embora fossem adversárias políticas, ambas as famílias se organizavam e se revezavam no poder em torno do PRP, fundado em 1878 na cidade de São Carlos. Segundo Neves $(1984: 22)$,

$$
\begin{aligned}
& \text { "a luta política era, portanto, exclusivamente municipal, } \\
& \text { arregimentando-se as hostes em dois bandos antagônicos, disputando } \\
& \text { tão somente o controle político do município: constituía o grupo } \\
& \text { vencedor o Diretório do Partido governista, que ocupava os cargos de } \\
& \text { administração local, ficando o grupo vencido como a ala dissidente e } \\
& \text { inconformada do mesmo partido" }
\end{aligned}
$$

A composição de prefeitos e vereadores em São Carlos começou a ser alterada a partir das eleições municipais de 1936 e, sobretudo, com as eleições de deputados, prefeitos e vereadores em 1947. Ao estudar a formação da estrutura administrativa pública em São Carlos durante os anos de1930 até 1960, Abreu (2000:50) aponta que o período das intervenções federais nos estados e municípios, iniciado com a Revolução de 30 e intensificado com o Estado Novo, não alterou as características do poder público executivo na cidade de São Carlos. Os dois prefeitos nomeados pelo interventor federal pertenciam à oligarquia agrária local. Após a Revolução de 1930, a Prefeitura foi dirigida de forma intermitente por diversos prefeitos-interventores por períodos muito curtos até 1938. Durante o Estado Novo, foram nomeados pelo Interventor Federal, os prefeitos Carlos de Camargo Salles e Sabino de Abreu Camargo. O primeiro era agrônomo e participou da Revolução de 1932; o segundo, fazendeiro e produtor de café, governou São Carlos de 1941 até 1947, quando ocorreram as eleições diretas, 
tendo assumido o cargo o professor Luís Augusto de Oliveira, popularmente conhecido como Luisão (PREFEITURA MUNICIPAL DE SÃO CARLOS, Galeria do Prefeitos, 2012).

Pelo viés econômico, na década de 1930, São Carlos passava por profundas transformações. Enquanto declinava a produção agrícola, a produção industrial crescia rapidamente. As repercussões na composição da Câmara Municipal e na forma de atuação do poder público não tardaram a acontecer. Nas eleições de 1936, a participação da classe dos fazendeiros ainda era majoritária entre os vereadores, mas nas eleições de 1947 essa participação quase desapareceu, tendo sido eleitos apenas dois fazendeiros entre os vinte e sete vereadores, e ainda com pequena parcela de votos. Em sua maioria, os representantes da população eram comerciantes, industriais e prestadores de serviços, como médicos, advogados e contadores.

A Câmara Municipal de São Carlos, em 1936, era composta (entre efetivos e suplentes), por 26 vereadores, dos quais 9 eram fazendeiros, 7 comerciantes, 5 industriais, 2 contadores, 2 médicos e 1 advogado. Nas eleições de 1947, dos 27 vereadores, 8 eram industriais, 6 comerciantes, 2 fazendeiros, 2 dentistas, 2 médicos, 2 funcionários públicos, 2 professores, 1 contador, 1 empresário e 1 farmacêutico. A tabela abaixo permite visualizar melhor essas informações.

\begin{tabular}{|c|c|c|}
\hline \multirow{2}{*}{\multicolumn{3}{|c|}{$\begin{array}{l}\text { Tabela16: Composição da Câmara Muni } \\
\text { segundo a profissão dos vereadores, nas ele } \\
\text { VEREADORES }\end{array}$}} \\
\hline & & \\
\hline PROFISSÃO & ELEIÇÃO 1936 & ELEIÇÃO 1947 \\
\hline Fazendeiros & 09 & 02 \\
\hline Industriais & 07 & 08 \\
\hline Comerciantes & 05 & 06 \\
\hline $\begin{array}{l}\text { Funcionários públicos, } \\
\text { profissionais liberais e } \\
\text { prestadores de serviço }\end{array}$ & 05 & 11 \\
\hline TOTAL & 26 & 27 \\
\hline
\end{tabular}


Fonte: Elaborado pelo autor com base em: CÂMARA MUNICIPAL DE SÃO CARLOS. Setor de Recepção, Expedição e Registro de Documentos Oficiais. Cadastro de vereadores.

Para compreender esse processo de mudanças dos agentes no poder público municipal, Costa (2001) analisou os principais fatores e acontecimentos que levaram os e descendentes de imigrantes ao poder. Como resultado de sua pesquisa, chegou às seguintes conclusões: a inserção na política deu-se a partir da crise do café, pois muitos fazendeiros perderam seu poder econômico; o fechamento das Câmaras em 1937 e a criação de cargos no Governo Vargas levaram à inserção de descendentes de imigrantes na política local; o nível de instrução e a participação em associações, relações de parentesco ou amizade e assimilação dos partidos políticos proporcionou distinção e prestígio de alguns indivíduos.

Nesse percurso de mudanças econômicas durante as décadas de 1930 e 1940, aliadas à política ditatorial e populista da Era Vargas, pode-se afirmar que houve uma progressiva reestruturação da elite social e da composição do poder público em São Carlos. Em outras palavras, na passagem de uma economia agrário-exportadora para urbano-industrial foram criadas as condições político-jurídicas para o desenvolvimento do capitalismo industrial e urbano. Conforme mostraremos, a burguesia e a classe média retiraram da agenda municipal as questões relativas à grande propriedade rural e direcionaram a atenção para atividades e demandas de novos setores urbanos, economicamente mais representativos.

Ao longo das décadas de 1950 e 1960, a representação dos vereadores por profissão ocorreu conforme é mostrado na tabela abaixo. Verificamos que a partir da década de 1950 não havia mais fazendeiros atuando em nenhuma esfera na política de São Carlos. 


\begin{tabular}{|c|c|c|c|c|}
\hline \multicolumn{5}{|c|}{$\begin{array}{l}\text { Tabela 17: Composição da Câmara Municipal de São Carlos segund } \\
\text { vereadores, nas décadas de } 1950 \text { e } 1960\end{array}$} \\
\hline \multicolumn{5}{|c|}{ VEREADORES DE SÃO CARLOS } \\
\hline \multirow[t]{2}{*}{ PROFISSÃO } & \multicolumn{4}{|c|}{ MANDATO } \\
\hline & $(1952-1955)$ & $(1956-1959)$ & $(1960-1963)$ & $(1964-1969)$ \\
\hline FAZENDEIROS & --- & --- & --- & --- \\
\hline INDUSTRIAIS & 03 & 02 & 03 & 01 \\
\hline COMERCIÁRIOS & 04 & 02 & 01 & 03 \\
\hline FUNC. PÚBLICO & 03 & 02 & 02 & 05 \\
\hline SERVIÇOS* & 09 & 13 & 13 & 10 \\
\hline TOTAL & 19 & 19 & 19 & 19 \\
\hline
\end{tabular}

*Na categoria "serviços" incorporamos as seguintes profissões: médico, advogado, contador, ferroviário, farmacêutico, professor, bancário, enfermeiro, mecânico, escriturário e funcionário do SESI.

Fonte: Elaborado pelo autor com base em: CÂMARA MUNICIPAL DE SÃO CARLOS. Setor de Recepção, Expedição e Registro de Documentos Oficiais. Cadastro de vereadores.

O executivo também passou a ser ocupado por industriais, funcionários públicos e prestadores de serviços. O prefeito Luís Augusto de Oliveira, um dos professores mais conhecidos da cidade, governou de 1948 até 1950, quando foi eleito deputado estadual, assumindo seu lugar o industrial Leôncio Zambel. Este foi sucedido pelo funcionário público (tesoureiro da prefeitura) Antonio Massei (1952-1955). Em 1955, Luís A. de Oliveira foi eleito prefeito de São Carlos pela segunda vez, mas faleceu em 1956. Em seu lugar, assumiu o médico Alderico Vieira Perdigão, que governou até 1959. Entre 1960 e 1963, Antonio A. Lobbe, diretor da S/A Indústrias Giometti, governou o município. Antonio Massei assumiu o cargo em 1964 pela segunda vez, governando até 1969. Vê-se que a prefeitura foi governada por professor, médico, funcionário público e industriais. 
Os industriais tiveram representação, principalmente, com o prefeito Antonio Adolphe Lobbe, com o vice-prefeito Carmine Botta e com os vereadores Ernesto Pereira Lopes, Leôncio Zambel, Dr. Emílio Fehr e Mario Maffei, esse último chegando à prefeitura na década seguinte. A tabela abaixo mostra os dirigentes do executivo e do legislativo em São Carlos de 1948 a 1969.

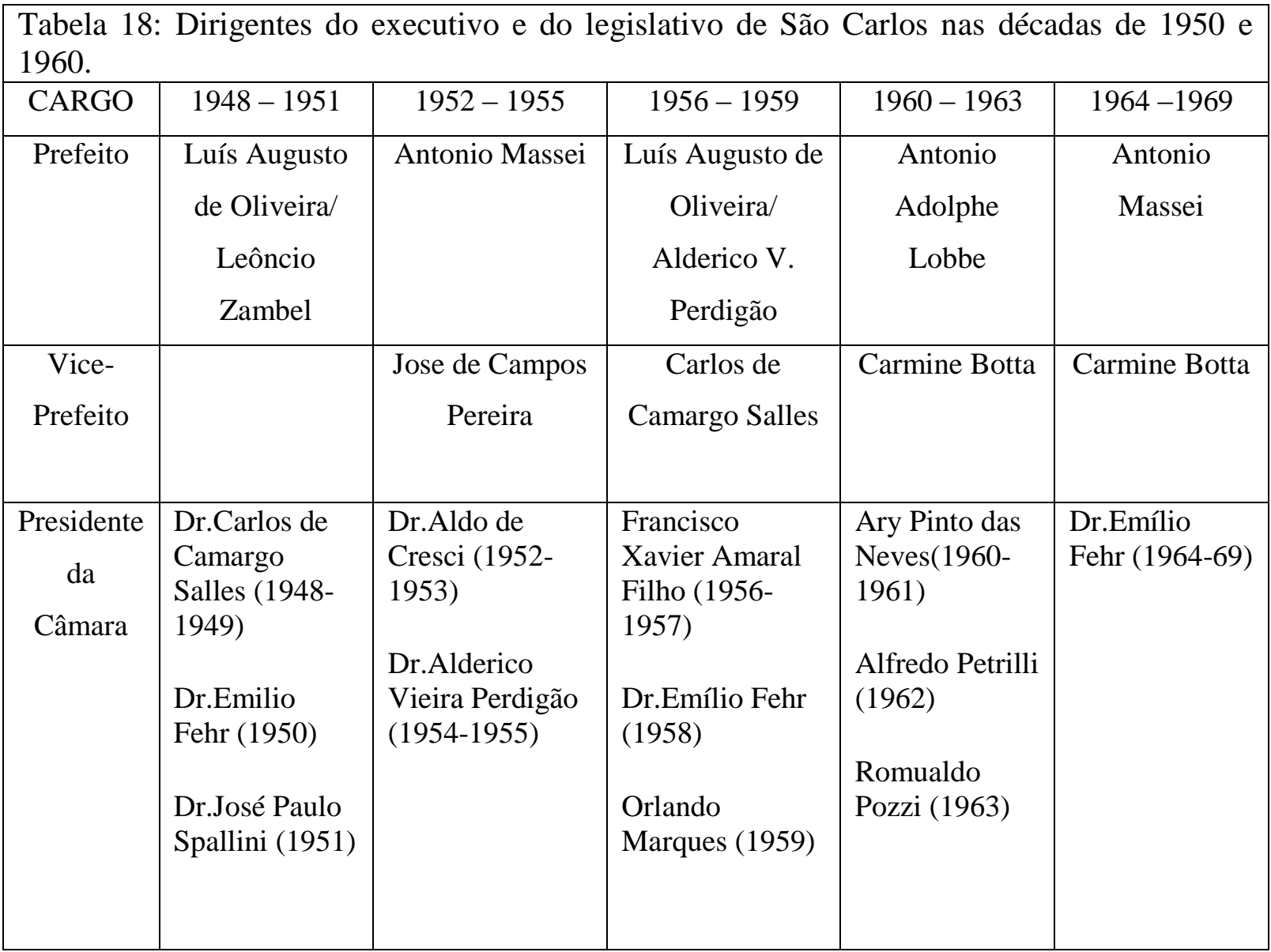

Fontes: Elaborado pelo autor com base em: PREFEITURA MUNICIAPAL DE SÃO CARLOS, Galeria dos Prefeitos, http://www.camarasaocarlos.sp.gov.br/novo/portalold/index.php/conheca-acamara/listas-dos-presidentes.html ${ }^{20}$

Entre os políticos de São Carlos que ultrapassaram as fronteiras municipais, atuando no legislativo estadual e federal, se destacam os deputados Ernesto Pereira Lopes e Miguel Petrilli, ambos com ligação na indústria local. $\mathrm{O}$ primeiro foi $\mathrm{o}$ personagem mais conhecido em São Carlos após 1930, desempenhando também as

${ }^{20}$ Acesso em janeiro de 2015 . 
funções de médico e, sobretudo, empresário industrial, dono das indústrias Pereira Lopes.

Fernando Pereira Lopes ${ }^{21}$, neto de Ernesto Pereira Lopes, revela fatos importantes que levaram Ernesto a se tornar um dos industriais e políticos mais importantes do Brasil. Segundo Fernando, a IPL (Indústria Pereira Lopes), fundada em 1946 em São Carlos, teve sua origem na década de 1930 na cidade de São Paulo com uma iniciativa de Mario Pereira Lopes com ajuda do pai, que financiava Mario em seu empreendimento de fabricar produtos elétricos (motores, fogões, rádios, etc.) com a condição de que Mario incluísse seus irmãos Ernesto, José e Otávio como sócios.

Na década de 1930, o proprietário das lojas Isnard, localizada na cidade de São Paulo, decidiu financiar a produção nacional de fogões elétricos, quando os fogões ainda eram importados. A ideia era de que alguma indústria fabricasse e as lojas Isnard fizessem a comercialização. Sabendo da competência do engenheiro Mario Pereira Lopes, o proprietário da loja emprestou o capital inicial para Mário fabricar fogões e outros produtos elétricos. Com o início da produção, a loja passou a vender os produtos.

Ernesto Pereira Lopes era médico e não tinha ligação com a fabricação dos produtos, idealizada e efetivada pelo engenheiro Mario. Ernesto, por estar acometido por um problema de saúde e trabalhar muito em São Paulo, a convite de seu padrinho Antonio Militão, que era prefeito de São Carlos, decidiu se tratar e montar seu consultório médico nessa cidade. Pouco tempo depois, os irmãos Mário e Ernesto Pereira Lopes compraram um terreno próximo à Vila Prado e decidiram montar a IPL para fabricar fogões elétricos e geladeiras em São Carlos. Fernando salienta que a razão de montarem a indústria no interior de São Paulo deve-se ao fato Ernesto ter vindo se tratar na cidade e montar seu consultório médico, iniciando também sua vida política nesse município, reiterando que é errônea a ideia de que poderia ter sido a posição

21 Entrevista concedida em 30/06/2014 pelo empresário industrial Fernando Pereira Lopes, sócio da indústria de fios de algodão Rossignollo. Os dois avôs de Fernando eram médicos, industriais e políticos em São Carlos: o já citado Ernesto Pereira Lopes e também Emílio Fher, este último, fillho do precursor da indústria são-carlense, o suíço Germano Fehr. Foi através de Emílio que Fernando ingressou na indústria do ramo têxtil. 
estratégica de São Carlos no centro do estado de São Paulo o fator que levou à instalação nessa cidade.

Segundo Paino (2002), advogado e ex-sindicalista de São Carlos, Ernesto prestava relevantes serviços humanitários atuando como médico, fato que contrastava com a maneira truculenta que a IPL tratava seus funcionários, conforme denunciado pelo próprio Paino. Foi devido à sua popularidade como médico que Ernesto se elegeu vereador e foi presidente da câmara a partir de 1937. Somente em 1946 ele fundaria a IPL, juntamente com seu irmão Mario.

A carreira política de Ernesto prosperou. Filiado à UDN, foi eleito deputado da Assembléia Constituinte estadual paulista em janeiro de 1947. Já conhecido como um próspero industrial, em outubro de 1950, foi eleito deputado federal, deixando a Câmara em janeiro de 1955. Conseguiu a reeleição em 1958 e 1962, sempre pela legenda da UDN. Com a instauração do bipartidarismo após a edição do Ato Institucional $n^{\circ} 2$, em 27 de outubro de 1965, filiou-se à Aliança Renovadora Nacional (ARENA), sendo reeleito deputado federal nos pleitos de 1966 e de 1970. O empresário industrial ainda seria presidente da Câmara dos Deputados em fevereiro de 1971, após ter sido indicado pelo governador de Minas Gerais, Rondon Pacheco, e ratificado pelo presidente Emílio Médici. Encerraria sua carreira política no ano seguinte, se dedicando exclusivamente à indústria (ABREU; BELOCH, 1984).

Outro industrial que se tornou deputado estadual foi Miguel Petrilli, porém sua carreira como industrial foi bem curta, sendo mais conhecido como político e pecuarista. Filho de imigrantes italianos, que chegaram bem jovens ao Brasil para trabalhar como colonos em fazendas de café da região, Miguel Petrilli fez seu curso primário e secundário na antiga Escola "Dante Alighieri" e na escola de Comércio "Julien Fauvel" de São Carlos, onde se formou. Trabalhou na cidade, no distrito de Ibaté, até 1937, fabricando bebidas e refrigerantes por sua conta em uma pequena indústria de propriedade de seus pais. Em 1947, na primeira legislatura após a queda de Getúlio Vargas, elegeu-se deputado estadual pelo Partido Democrata Cristão (PDC), exercendo três mandatos consecutivos até 30 de março de 1959, quando abandonou definitivamente a política (CÂMARA MUNICIPAL DE SÃO CARLOS. PROCESSO No 2485/01 - PROJETO DE LEI No 229). Seu irmão, Leonardo Petrilli, continuou com a indústria de bebidas em São Carlos.

Entre as realizações desses deputados por São Carlos pode-se destacar a força política que exerceram para aprovar a instalação das duas universidades públicas do 
município, USP e UFSCar. Nas décadas de 1950 e 1960, foram instaladas a Escola de Engenharia de São Carlos (USP) e a Universidade Federal de São Carlos,a primeira instituição federal de Ensino Superior localizada no interior do Estado de São Paulo.

O texto da Lei Estadual $n^{\circ} 161$, de 24/9/1948, dispõe sobre a criação de estabelecimentos de ensino superior em cidades do interior do Estado. O Artigo $1^{\circ}$ instituiu a criação no interior do estado e subordinada à Universidade de São Paulo, a Escola de Engenharia de São Carlos. Visando a sua efetiva implantação pelo poder executivo, foram tomadas diversas iniciativas de políticos, tanto pelo governo estadual quanto pelo municipal. Entre os políticos de São Carlos envolvidos na implantação da USP em São Carlos encontram-se os nomes de Antonio Massei (prefeito municipal), Aldo de Cresci (presidente da Câmara Municipal), Ernesto Pereira Lopes (deputado federal), Luís Augusto de Oliveira, Miguel Petrilli e Vicente Botta, (deputados estaduais). Outros nomes provenientes de São Carlos são Germano Fehr Júnior, delegado do Centro das Indústrias do Estado de São Paulo e João Leopoldino Fraguas, presidente da Associação Comercial e Industrial

As aulas tiveram início em abril de 1953, no antigo prédio da extinta Sociedade Italiana Dante Alighieri, mas em 1956 foi transferida para um terreno de forma irregular medindo $21.500 \mathrm{~m}^{2}$ que foi doado à USP pela Prefeitura no ano de 1954 , onde se constituiu o campus universitário (CÂMARA MUNICIPAL DE SÃO CARLOS, LEI $\mathrm{N}^{\mathrm{o}} 1946$, de 23 de agosto de 1954).

A figura a seguir mostra o edifício E-1 em 1957, construído segundo estética modernista. 


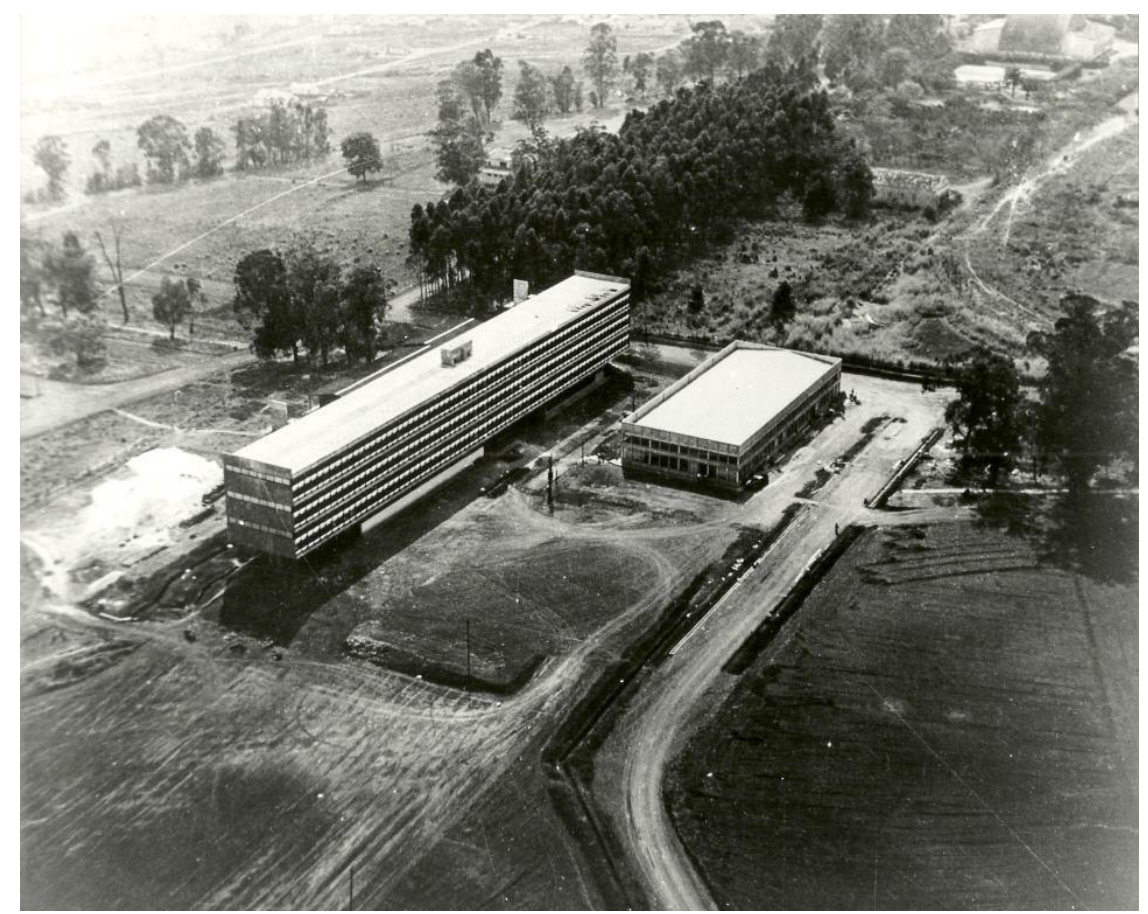

Figura 22: Prédio E-1 da Escola de Engenharia de São Carlos, 1957.

Fonte: Acervo Pró-Memória da Prefeitura Municipal de São Carlos.

Em 1969, São Carlos contava com uma população de 100 mil habitantes (Anuário Estatístico do IBGE, 1970). Já havia inúmeros cursos técnicos e de nível superior na área de engenharia. Em 1968, foi criada a Universidade Federal de São Carlos (UFSCar). Sua criação deve-se à influência que os políticos de São Carlos exerciam no Brasil.

Uma matéria de 10 de julho de 1966 do jornal A Folha relatava que na década de 1960 havia uma discussão a respeito da instalação de uma universidade federal em São Carlos. Segundo a matéria, um dos últimos atos de Juscelino Kubitschek foi a aprovação da Lei Federal No 3.885 de 13 de dezembro de 1960, localizando em São Carlos a Universidade Federal de São Paulo.

O industrial Antonio A. Lobbe, prefeito de São Carlos, já havia desapropriado uma área lindeira à rodovia Washington Luís, ao lado da Av. Getúlio Vargas para a instalação da Universidade, mas ao ato foi alegado inconstitucionalidade, pelo fato de haver a Escola de Engenharia e o estado já contar com uma universidade federal. Contudo, os deputados federais de São Carlos, Ernesto Pereira Lopes (presidente da Câmara Federal) e Lauro Monteiro da Cruz trouxeram novamente a discussão sobre a instalação da universidade. Em outra matéria de 24 de julho de 1966, do jornal A Folha 
era estampada a manchete: "Inúmeros deputados na luta pela Universidade Federal em São Carlos". Uniram-se à causa os deputados de Araraquara. A matéria mostra o entendimento travado entre vereadores, deputados, o Ministro da Educação e o Presidente da República sobre a instalação da universidade. Por fim, pelo Decreto $\mathrm{n}^{\mathrm{o}}$ 62.758, de 22 de maio de 1968, foi aprovada a criação da Universidade Federal de São Carlos (UFSCar).

\section{3 - Incentivos às indústrias e regulação urbanística em São Carlos}

Nesse contexto das cidades que se industrializavam, a partir da década de 1930, iniciou-se uma nova forma de atuação do poder público sobre o urbano. Se, por um lado, o desenvolvimento industrial induz ao crescimento urbano, por outro, o poder público, ao atuar sobre o urbano, cria as condições para impulsionar o crescimento industrial. Segundo Feldman (2005), as mudanças ocorridas no setor de urbanismo entre 1925 e 1936 evidenciaram uma linearidade no processo de construção do pensamento urbanístico, claramente identificado com as concepções do planning que se desenvolveu nas três primeiras décadas do século XX nos EUA e que foram difundidas no Brasil por Anhaia Mello. Feldman (2010) aponta ainda que as próprias mudanças que ocorreram no Brasil na década de 1930, no âmbito da economia, da política, da organização social, da administração pública e do desenvolvimento urbano, forçaram o alargamento da concepção de urbanismo e a reconstrução de saberes e práticas urbanísticas. Villaça (1993) aponta que os planos de melhoramento e embelezamento das cidades, tipicamente de economias coloniais, cederam lugar ao planejamento urbano, ideologicamente fundamentado no estudo da racionalidade econômica da produção do espaço. Os urbanistas brasileiros, como agentes do poder público, passaram a admirar o Regional Survey of New York and Its Environs, de 1927, o qual se baseava em três linhas de investigação: os requisitos espaciais das funções econômicas; as tendências nas mudanças de demandas por espaço; o futuro dessas tendências.

No final da década de 1920, devido ao crescente número de indústrias instaladas em São Carlos, houve necessidade de estabelecer algumas regras para instalação de fábricas insalubres. De acordo com o Código de Posturas de 1929, era proibido, dentro da 
cidade, o funcionamento de fábricas de sabão, óleo e velas; curtumes; máquinas de beneficiar café, arroz e milho; depósito de sal em grande quantidade; e outros estabelecimentos que exalassem vapores nocivos à atmosfera; prejudicassem a salubridade pública ou causassem algum incômodo à vizinhança (SÃO CARLOS, 1929, artigo 123).

Segundo Lima (2007:59), o Código de Postura de 1929 incorporou parte das mudanças trazidas por novos paradigmas urbanísticos, relativo ao crescimento urbanoindustrial e ao alargamento da concepção de urbanismo que ocorreu, sobretudo, na década de 1930. Através de consulta à legislação municipal entre as décadas de 1930 e 1960 e da bibliografia corrente sobre São Carlos, pode-se afirmar que, apesar do intenso processo de industrialização e urbanização, o poder público atuou de forma pontual na provisão de infraestruturas, formação de mão de obra e incentivos fiscais.

Algo que favoreceu a indústria foram as escolas técnicas em São Carlos. Draibe (2004:62) aponta que nos primeiros anos da década de 1930, foram estruturadas no Ministério da Educação, a Inspetoria do Ensino Profissional e Técnico e a Divisão do Ensino Industrial. Em São Carlos, foi fundada a Escola Industrial Paulino Botelho em 1932 (figura 23). Na Escola Industrial havia os cursos de Mecânica de Automóveis, de Alvenaria e Revestimentos e de Tipografia e Encadernação. Em 1949, foram criados os cursos de Alfaiataria e de Fiação e Tecelagem (LEI N. 373, DE 25 DE JULHO DE 1949). Esses cursos estavam direcionados para os ramos de indústrias que mais cresceram em São Carlos: Metal-Mecânica, Mobiliário e produtos para Educação, Diversão e Comunicação, respectivamente, conforme mostramos no capítulo 02. 


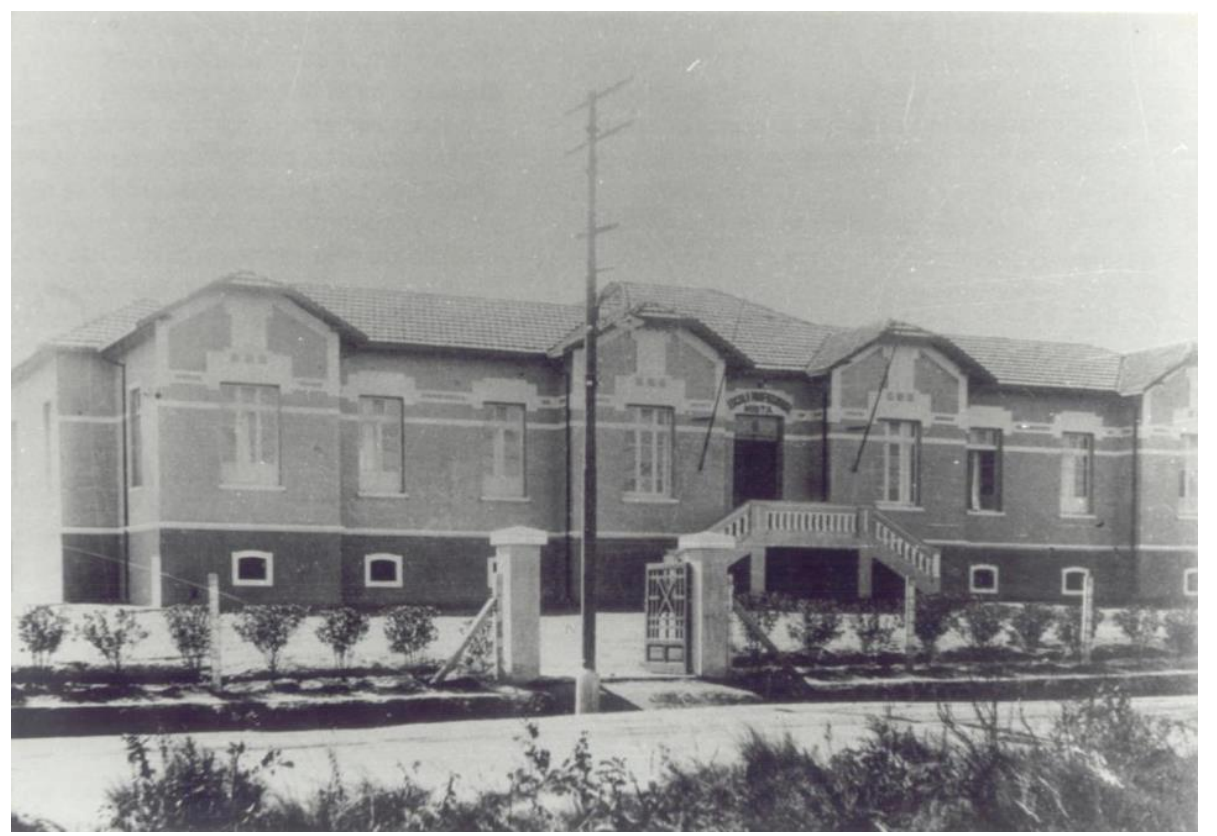

Figura 23: Escola Industrial Paulino Botelho em São Carlos, 1933.

Fonte: Acervo Pró-Memória da Prefeitura municipal de São Carlos.

Entre os anos de 1942 e 1946, foram sancionadas no âmbito federal as Leis Orgânicas do Ensino Industrial e Comercial e instituído o sistema SENAI-SENAC para educação dos trabalhadores urbanos (2004:62). Em São Carlos, no ano de 1944, os serviços de caráter educativo, organizado e dirigido pelo SENAI (Serviço Nacional de Aprendizagem Industrial) ficaram isentos dos impostos municipais (CÂMARA MUNICIPAL DE SÃO CARLOS, LEI No 625, de 14 de janeiro de 1944). Em consequência, no ano de 1949, foi construído o prédio da escola SENAI, localizada entre a Vila Prado e a estação ferroviária. O SENAI iniciou suas atividades em 1951, com cursos profissionalizantes na área de marcenaria, carpintaria, mecânica e eletricidade $^{22}$. No mesmo ano, doou áreas de terreno na Vila Prado para a Prefeitura, destinadas a abertura ou prolongamento de vias públicas para melhorar a comunicação entre os bairros da região sul, onde se concentrava a população operária, com as indústrias e o centro comercial da cidade (CÂMARA MUNICIPAL DE SÃO CARLOS, LEI No 1134, de 1949). Em 1950, o SESI e o SENAI ficaram isentos dos impostos municipais (CÂMARA MUNICIPAL DE SÃO CARLOS, LEI No 1335, de 30 de dezembro de 1950).

${ }^{22}$ Disponível em: http://sãocarlos.sp.senai.br/institucional/299/0/ historico (acesso em janeiro de 2015) 
Através de entrevistas $^{23}$, industriais de São Carlos afirmaram a importância da mão de obra qualificada no município, provenientes das escolas técnicas e das próprias indústrias, que também eram formadoras de operários. Ítalo Cardinali Filho relata que todas as indústrias do ramo de injeção de plástico instaladas em São Carlos foram fundadas por ex-funcionários da Indústria Cardinali, que aprenderam o ofício na indústria. Para Ítalo, esse acontecimento foi positivo para as indústrias, pois criou um polo industrial que favoreceu todas as outras. Fernando Pereira Lopes também salienta a importância da mão de obra ao citar as escolas e afirma que é vantajoso ter uma indústria cercada de outras com muitos funcionários preparados do que estar sozinho e ter que formar a mão de obra. Ítalo Cardinali lembra ainda que a imigração italiana para São Carlos no final do século XIX (Fachina, Giometti, Casale, Cardinali) constituiu importante presença de mão de obra. Posteriormente, com as inúmeras escolas primárias e secundárias e, após a década de 1930, com as escolas profissionalizantes, São Carlos foi ampliando o mercado de trabalho qualificado. Além dessa formação técnica, Ítalo relata que as exposições que o SENAI realizava todos os anos eram muito importantes para incentivar a população ao ingresso na indústria mas, antes, fazer o curso.

"Fazia-se um showroom de todas as empresas no SENAI [...] todas as empresas iam lá para incentivar o jovem a visitar o showroom das empresas, para ir trabalhar em uma dessas empresas, mas antes fazer o SENAI. Então o próprio SENAI articulava isso com as empresas"

A Escola de Engenharia de São Carlos (EESC) que, a partir de 1953 funcionou no antigo prédio da extinta Sociedade Italiana Dante Alighieri, na rua 9 de Julho, foi transferida para uma área bem maior, onde se constituiu o campus universitário, em 1956. Nos cursos da USP durante a década de 1950, constavam um curso fundamental e um intermediário, como base científica indispensável ao estudo das ciências gerais do engenheiro. Os cursos de aplicação constituíam o estudo dos processos característicos da Engenharia, agrupados nas suas especializações mais importantes para a região e para o país na época. Em 1956, foram instalados os cursos de aplicação em Engenharia Mecânica e Engenharia Civil (Decreto 24.263-A, de 26/1/1955).

${ }^{23}$ Entrevista concedida por empresários de São Carlos em 30/06/2014 : Ítalo Cardinali Filho ex-industrial que trabalha no ramo imobiliário, e Fernando Pereira Lopes, proprietário de indústria. 
A UFSCar recebeu, no ano de 1970, seus primeiros alunos para os cursos de Licenciatura em Ciências e Engenharia de Materiais, pioneiro na América Latina. Vê-se que os cursos de ambas as universidades estavam direcionados para formação de mão de obra qualificada e para inovação em ciência e tecnologia.

A partir da consulta da legislação municipal e estadual, mostramos que a Prefeitura e o Governo do Estado tomaram medidas no sentido de dotar o município de infraestruturas de transportes urbanas e intermunicipal, visando o crescimento industrial. Em 1943, foi declarado de utilidade pública, para o fim de ser expropriada pela Fazenda do Estado, uma faixa de terra com a área de $1.147 .335 \mathrm{~m}^{2}$, situada no distrito de Ibaté e nos municípios de Araraquara e São Carlos, necessária à construção da Rodovia Araraquara-São Carlos. As despesas para a construção ficaram por conta das verbas próprias do Departamento de Estradas de Rodagem - DER (ASSEMBLEIA LEGISLATIVA DO ESTADO DE SÃO PAULO, DECRETO N. 13.363, DE 12 DE MAIO DE 1943).

A construção dessa rodovia foi importante para a ligação de São Carlos com Araraquara e, alguns anos mais tarde, com Rio Claro e São Paulo, quando teve início o seu prolongamento através da construção da Rodovia Rio Claro-São Carlos. Em 1949, foi declarada de utilidade pública, para ser desapropriada pelo DER, uma faixa de terra com a área de 2.937.940,00m² (ASSEMBLEIA LEGISLATIVA DO ESTADO DE SÃO PAULO, DECRETO N. 18.566, DE 7 DE ABRIL DE 1949). Essas duas rodovias mencionadas haveriam de formar a atual Rodovia SP-310, denominada Rodovia Washington Luís. Como conseqüência, a partir de 1949, as grandes indústrias se instalaram as margens da rodovia.

Em 1948, a lei no 995 autorizou a execução, mediante concorrência pública, de calçamento a paralelepípedos, de cento e quinze quarteirões, mas a lei não especificava os locais (CÂMARA MUNICIPAL DE SÃO CARLOS, LEI No 995 de 1948).

Em 1951, foram aprovadas algumas leis relacionadas ao transporte rodoviário: pela Lei $n^{\circ} 1360$, foi criada na Diretoria de Obras da Prefeitura, uma seção especial de estradas e caminhos municipais sob denominação de "Serviço de Estradas de Rodagem Municipal”; a Lei n 1438 aprovou um contrato lavrado em 24 de agosto de 1951 para a construção de uma estação rodoviária em terreno do Patrimônio Municipal, celebrado entre Miguel Petroni e a Prefeitura; a Lei $\mathrm{n}^{\circ} 1456$ autorizou contratar por meio de concorrência pública, empresa para realizar o serviço de transporte coletivo por meio de 
ônibus, para servir aos bairros da cidade (CÂMARA MUNICIPAL DE SÃO CARLOS, LEIS No 1360, 1438 e 1456, de 1951).

Em matéria publicada no jornal Correio de São Carlos em 1955, o referido jornal destacava obras de infraestrutura urbana realizada pelo poder público, a saber, o calçamento de cento e dezesseis quarteirões em diversos setores da cidade onde as ruas apresentavam-se com buracos, e os problemas urbanos a serem resolvidos: reparação das pontes e retificação do Córrego Gregório tendo em vistas as constantes enchentes na região do Mercado Público Municipal (Correio de São Carlos, 3 de fevereiro de 1955).

Após a criação da seção especial de estradas e caminhos municipais, em 1951, foi autorizada a criação do SERM (Serviço de Estradas de Rodagem do Município de São Carlos) no ano de 1960, ao qual competiam os encargos de construção, melhoramentos, pavimentação e conservação das estradas e caminhos municipais, além de serviços afins (CÂMARA MUNICIPAL DE SÃO CARLOS, LEI No 4113 de 01 de novembro de 1960).

No ano de 1962, o mesmo ano em que o bonde elétrico foi desativado, a Prefeitura foi autorizada a receber um empréstimo do Governo Estadual no valor de 20.000.000 Cr\$ para as obras do viaduto sobre os trilhos da C.P.E.F, ligando os bairros Vila Prado e arredores com o centro (CÂMARA MUNICIPAL DE SÃO CARLOS, LEI No 4504 de 04 de setembro de 1962). O viaduto faz a ligação da área com maior número de operário com a região onde se concentra as indústrias e o comércio.

A Lei n ${ }^{\circ} 5411$ de 1966 autorizou a pavimentação por asfalto da Av. São Carlos e da Rua General Osório, incluindo obras de esgoto e água. Essas ruas eram, sobretudo até a década de 1950, os locais de concentração das atividades industriais, bancárias e de comércio (CÂMARA MUNICIPAL DE SÃO CARLOS, LEI Nº 5205 de 07 de maio de 1966; LEI No 5206 de 11 de maio de 1966).

O transporte coletivo urbano por ônibus estava em circulação no começo da década de 1960. Em 1969, o Guia de Informação de São Carlos indicava os itinerários e os horários de partidas e chegadas dos ônibus. Havia dez linhas de ônibus, mas no guia constava que, além das linhas convencionais, a empresa colocava a disposição carros especiais para horários das fábricas, colégios, futebol, enterros e aos domingos e feriados pra o Espraiado.

Para os transportes intermunicipais de cargas e pessoas, o trem ainda funcionava em 1969, mas havia quatro empresas de ônibus com itinerários fixos: Viação Cometa S/A, Empresa Cruz, Viação Jauense Ltda. e Viação Marchiori. 
A tábua itinerária do trem em 1969 constava onze municípios (Brasília, São Paulo, Analândia, Araraquara, Brotas, Ibaté, Itirapina, Luis Antônio, Ribeirão Bonito, Rincão e Rio Claro). A tábua itinerária rodoviária constava, além destes municípios, mais vinte e um municípios (Ribeirão Preto, Santa Eudóxia, Água Vermelha, Descalvado, Porto Ferreira, Leme, Araras, Taquaritinga, Monte Alto, Novo Horizonte, Campinas, Ibitinga, Tabatinga, Nova Europa, Mogy, Bonfim Paulista, Piracicaba, Pirassununga, Matão, Jaboticabal e Bocaina) (SÃO CARLOS: Guia de informações, 1969). Portanto, em 1969, o transporte rodoviário de pessoas havia superado largamente as ferrovias.

No sentido de estimular o desenvolvimento da indústria em São Carlos, a Prefeitura tomou outras medidas para favorecer esse setor. Como mostra o anúncio abaixo, publicado em 1938 no jornal Correio de São Carlos, a Prefeitura se articulava com o setor privado para que a cidade recebesse novos investimentos em indústrias.

\section{Favorecendo as indústrias no Município}

\section{$\mathrm{O}$ sr. dr. Prefeito devera baixar um ato legislativo a respeito}

O sr. dr. Prefeito municipal, considerando a elevada importancia que as industrias representam para o progresso de nossa cidade e municipio, resolveu tomar medidas que venham favorecer as industrias existentes $\mathrm{e}$ as que futuramente vierem a existir, concedendo-lhes isenção de impostos. Essa isenção estabelecerá um prazo relativo, de acôrdo com o capital empregado em cada um dos estabelecimentos industriaes.

Tratando de uma medida de elevado alcance para o futuro do municipio, pois uma vez decretado esse ato legislativo S. Carlos abrirá suas portas para novas industrias; o sr. dr. Teixeira de Barros, governador da cidade resolveu submeter á apreciação do departamento das Municipalidades um projeto de um ato legislativo regulamentando o assunto.

Afim de que a imprensa e outras pessoas autorizadas no assunto se manifestem a respeito, apresentando suas sugestões, o sr. prefeito municipal resolveu publicar o seguinte projeto de Ato, que não deixará de merecer a atenção de todo quanto vêem neste gesto uma ação eminentemente construtora digna de aplausos (sic) [Correio de São Carlos, 3 de maio de 1938] 
O anúncio continua mostrando na íntegra o Ato Legislativo, que especifica todas as regras que a indústria ficaria condicionada por contrato para ser beneficiada, v.g., número e qualidade de empregados, valor do capital invertido, valor do imóvel, etc. Os $\operatorname{artigos} 4^{\circ}, 5^{\circ}$ e $6^{\circ}$ especificam o seguinte:

“Art. 4.0 - A transferência de terrenos municipais para a instalação de novas industrias, será sempre condicional e subordinada ao funcionamento da industria dentro do prazo e depois de cumpridas as condições que foram estipuladas no contrato.

Art. 5.0 - Fica facultado á Prefeitura localizar as novas industrias que se beneficiarem dos favores deste ato, para atender a segurança, saúde e bem estar da população e á formação do bairro industrial da cidade. (sic) [Correio de São Carlos, 3 de maio de 1938]

Vê-se que a Prefeitura pretendia ceder terrenos para a instalação de indústrias, determinando a localização das instalações visando os interesses da população (segundo o Ato). Abaixo, segue um anúncio de 1942 do mesmo jornal, mostrando como a ACISC e a Prefeitura se articulavam para a instalação de indústrias.

\section{Incentivando a instalação de novas indústrias}

A Associação Comercial e Industrial de São Carlos, visando sempre o aumento do numero de estabelecimentos industriais e comerciais nessa cidade, não poupa esforços e está procurando estar em contato com as grandes industrias da Capital e demais Estados com referência à instalação de filiais nesta cidade.

O ofício que abaixo transcrevemos demonstra os esforços da diretoria da Associação Comercial de São Carlos:

“À Standard Brands of Brazi Inc. - Rio de Janeiro. - Prezados senhores. Tendo chegado ao conhecimento da Associação Comercial e Industrial de São Carlos, que VV.SS. pretendem montar uma fábrica dos afamados 'Fermentos Fleischmann' no interior do Estado de São Paulo, pela situação privilegiada no ponto mais central do Estado de São Paulo, sede de importantes entroncamentos ferroviários, rodoviários, servida por excelentes estradas de rodagem estaduais e municipais, acrescendo a tudo isso ser o maior parque industrial do interior, e o pequeno custo da mão de obra, melhor se aconselha para o estabelecimento que VV.SS. pretendem montar. 
Outrossim, colocamo-nos à disposição de VV.SS. para quaisquer informações que se tornem necessárias, bem como para auxiliá-los na obtenção de impostos e outros favores. Sem outro assunto, somos muito atenciosamente, de VV.SS. pela Associação Comercial e Industrial de S. Carlos, LEÔNCIO ZAMBEL - Presidente" (SIC). [Correio de São Carlo, 15 de janeiro de 1942]

Este anúncio demonstra claramente a intenção de trazer investimentos industriais para São Carlos, além de mostrar a relação entre industrialização e urbanização que estabelecemos em nosso estudo. Primeiramente, porque o objetivo do anúncio é mostrar que a Prefeitura visa à implantação de estabelecimentos comerciais e industriais. Em segundo lugar, demonstra que os agentes do poder público que decidem sobre a isenção de impostos e "outros favores", são os próprios industriais e comerciantes. O Sr. Leôncio Zambel, que foi prefeito, vereador e presidente da câmara, foi também presidente da ACISC (Associação Comercial e Industrial de ao Carlos) e além disso, um industrial dos ramos de metalurgia e de construção. Por fim, atuou no parcelamento do solo urbano, implantando, em 1969, o loteamento Vila Monte Carlo, com 24,5 ha.

Em relação às virtudes da cidade, o anúncio destaca a mão de obra disponível para indústria e com baixo custo, a posição geográfica no centro do estado de São Paulo e a infraestrutura de transporte, elementos que induzem a ampliação da demanda de mercado e ao baixo custo de produção e escoamento.

A indústria Fleischman (uma marca de origem estadunidense), foi fundada por um austríaco em 1868 e em 1932 inaugurou uma filial em Petrópolis-RJ. Em 1948, surgiu a escola Fleischman de panificação, que teve um importante papel na formação de padeiros e na abertura de novas padarias no Brasil ${ }^{24}$, mas, para infelicidade da cidade de São Carlos, a filial do interior a qual se refere o anúncio de jornal foi inaugurada no município de Jundiaí no ano de 1954 (figura 24).

${ }^{24}$ Disponível em: http://www.fleischmann.com.br/sobre/ (acesso em janeiro de 2015) 


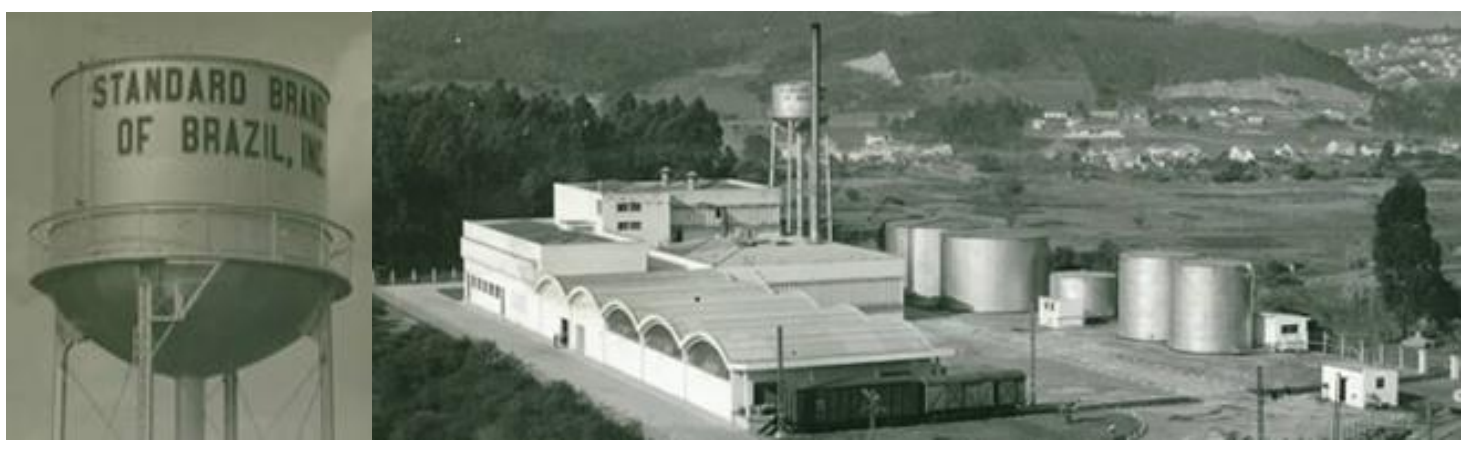

Figura 24: Unidade fabril da Fleischman em Jundiaí, 1954.

Fonte : http://www.fleischmann.com.br/sobre/ ${ }^{25}$

As indústrias instaladas em São Carlos recebiam algumas isenções de impostos por parte da Prefeitura. Em 1948, a Prefeitura adquiriu, por doação, terrenos destinados ao prolongamento das ruas Episcopal na direção sul e a construção de uma via pública

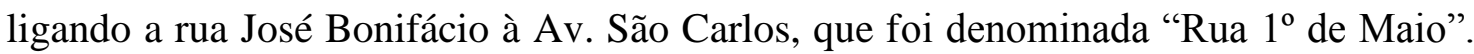
Os terrenos, em parte dos quais estavam instaladas uma tecelagem e uma fábrica de lápis, eram constantes de Companhia Fiação e Tecidos de São Carlos, Lápis Johann Faber Ltda, e José Duarte de Souza. Por essa doação, ficaram isentos do imposto territorial urbano e da taxa de remoção de lixo domiciliar as áreas remanescentes que faziam frente às novas vias públicas (CÂMARA MUNICIPAL DE SÃO CARLOS, LEI No 983, de maio de 1948).

Na década de 1950, começou haver uma atuação orientada tecnicamente sobre o espaço urbano. Em 1953, a prefeitura havia autorizado a contratação de um arquiteto especialista para estudar o planejamento do município (CÂMARA MUNICIPAL DE SÃO CARLOS, LEI No 1716, de 30 de abril de 1953) e em 1954, a prefeitura contraiu um empréstimo junto a Caixa Econômica Estadual de 70.394.235,00 Cr\$, destinados à reforma e ampliação dos serviços de abastecimento de água, sob orientação técnica do Departamento de Obras Sanitárias da Secretaria de Viação e Obras Públicas do Estado.

Em 1959, foi criada a comissão do Plano Diretor, com o objetivo de elaborar um planejamento para a cidade. Em 1962, foi concluído o primeiro Plano Diretor de São Carlos. Embora o Plano não tenha sido aprovado por lei, com a criação da Comissão para o Plano Diretor e da criação por decreto do Escritório Técnico do Plano Diretor de São Carlos em 1960, foi intensificada a aprovação de leis importantes.

25 Acesso em janeiro de 2015 
Com intuito de atrair novas indústrias para São Carlos, foram criadas duas leis no ano de 1965: a Lei $\mathrm{n}^{\circ} 5205$ autorizava a Prefeitura adquirir uma área de terreno para doar às novas indústrias que queriam se instalar nesta cidade; a Lei $\mathrm{n}^{\circ} 5206$ concedia isenção de impostos por 10 anos para as novas indústrias que se estabelecessem no município. Contudo, havia alguns requisitos para ser concedido o benefício, v.g., número mínimo de funcionários (CÂMARA MUNICIPAL DE SÃO CARLOS, LEI No 5205 de 07 de maio de 1965; LEI N 5206 de 11 de maio de 1965).

Em 1966, foi criada uma lei importante na regulamentação e incentivo para instalação de indústrias: a Lei Municipal nº 5319 delimitava a zona industrial na cidade, ficando estabelecida uma área ao sudeste, onde há uma larga avenida (Av. Getúlio Vargas) fazendo a ligação do início da Av. São Carlos com a Rod. Washington Luís. Na década seguinte, seria criado nessa área o Distrito Industrial de São Carlos.

\section{4 - Atuação dos industriais nos negócios imobiliários}

Além da representação majoritária na Câmara Municipal, com o acúmulo de capital, os empresários industriais tiveram atuação direta no processo de urbanização em São Carlos, se inserindo no ramo imobiliário. Segundo Melo (1992), a propriedade imobiliária se tornou campo de investimento de lucros da indústria e do comércio durante a década de 1940. Dois fatores contribuíram fortemente para a inversão de capitais no setor imobiliário e aceleração da especulação: a dificuldade de importação durante $2^{\mathrm{a}}$ Guerra Mundial e a Lei do Inquilinato de 1942. Em São Carlos, observamos que a expansão urbana se acelerou a partir do ano de 1948, com atuação de comerciantes e industriais no parcelamento do solo.

Através do cruzamento dos nomes de proprietários de indústrias e de loteamentos, identificamos os empresários industriais atuaram no parcelamento do solo, conforme as tabelas abaixo separadas por décadas. 


\begin{tabular}{|c|c|c|c|c|}
\hline \multicolumn{3}{|c|}{ LOTEAMENTO } & \multirow[b]{2}{*}{ Proprietário } & \multirow[b]{2}{*}{ Ramo industrial } \\
\hline $\begin{array}{c}\text { Ano de } \\
\text { implantação }\end{array}$ & Nome & Área & & \\
\hline 1939 & Jd. Bela Vista & 53,00 ha & $\begin{array}{c}\text { Saba \& Nicolau } \\
\text { Sallum }\end{array}$ & $\begin{array}{c}\text { Fábrica de meias } \\
\qquad(1938)\end{array}$ \\
\hline 1948 & Vila Lutfalla & 13,00 ha & $\begin{array}{c}\text { Fiação de Tecidos } \\
\text { Lutfalla }\end{array}$ & Têxtil \\
\hline 1948 & Vila Sônia & 3,30 ha & $\begin{array}{l}\text { Fiação de Sedas } \\
\text { São Carlos S/A }\end{array}$ & Têxtil \\
\hline 1949 & Vila Pelicano & 10,00 ha & Irmãos Pelicano & $\begin{array}{c}\text { Beneficiamento } \\
\text { de café }\end{array}$ \\
\hline 1949 & Vila São José & 34,00 ha & $\begin{array}{c}\text { José Ventura de } \\
\text { Medeiros }\end{array}$ & $\begin{array}{c}\text { Fábrica de } \\
\text { camisas (1937) }\end{array}$ \\
\hline 1949 & Vila Leonardo & $1,8 \mathrm{ha}$ & Leonardo Petrilli & $\begin{array}{c}\text { Fábrica de } \\
\text { Bebidas (1936) }\end{array}$ \\
\hline Total & 5 & 115,1 ha & & \\
\hline
\end{tabular}

Fonte: Elaborado pelo autor com base em: PREFEITURA MUNICIPAL DE SÃO CARLOS. Livro de impostos sobre indústrias e profissões para o ano de 1948. São Carlos: Fundação Pró-Memória de São Carlos. LIMA, 2007. ABREU, 2000;

Durante a década de 1930, foram implantados apenas dois loteamentos, totalizando uma área de 69,8 hectares. O primeiro, Jardim. São Carlos, era de propriedade da família Arruda Botelho e consistiu em uma extensão das ruas centrais Conde do Pinhal e 13 de Maio para além do Córrego do Gregório. O outro, o Jardim. Bela Vista, com 53 hectares, implantado por industriais em 1939, foi uma continuação da Vila Prado, que era um loteamento ocupado por um grande número de operários da nascente indústria em São Carlos. Importantes indústrias se instalaram no Jardim Bela Vista e arredores, como a IPL, a Tecelagem Germano Fehr e a indústria de camas Colmeia.

Foi precisamente em 1948 que teve início a grande expansão da área urbana em São Carlos. Em dois anos houve um aumento de 105,4 hectares de área loteada (ver mapa 11 
no capítulo 02), com presença preponderante dos industriais nos empreendimentos imobiliários. Do total da área loteada, $58 \%$ foi realizada por industriais (tabela 20).

Tabela 20: Empresários industriais atuantes no parcelamento do solo São Carlos nas décadas de 1950 e 1960

\begin{tabular}{|c|c|c|c|c|}
\hline \multicolumn{3}{|c|}{ Loteamento } & \multirow[b]{2}{*}{ Proprietário } & \multirow[b]{2}{*}{ Ramo industrial } \\
\hline $\begin{array}{c}\text { Ano de } \\
\text { implantação }\end{array}$ & Nome & Área & & \\
\hline 1950 & Vila Alpes & 11,00 ha & Marcilio Barbieri & $\begin{array}{c}\text { Oficina de } \\
\text { Ferreiro (1938) }\end{array}$ \\
\hline 1950 & Vila Arnaldo & $3,30 \mathrm{ha}$ & $\begin{array}{c}\text { Arnaldo } \\
\text { Antoniolli }\end{array}$ & $\begin{array}{c}\text { Fábrica de } \\
\text { calçados (1935) }\end{array}$ \\
\hline 1951 & Jardim Lutfalla & 15,50 ha & $\begin{array}{c}\text { Imobiliária } \\
\text { Lutfalla }\end{array}$ & Têxtil \\
\hline 1954 & $\begin{array}{c}\text { Jardim Cruzeiro } \\
\text { do Sul }\end{array}$ & 91,0 ha & $\begin{array}{c}\text { Imobiliária } \\
\text { Lutfalla }\end{array}$ & Têxtil \\
\hline 1955 & Vila Jacobucci & 26,0 ha & $\begin{array}{l}\text { Domingos } \\
\text { Jacobucci }\end{array}$ & $\begin{array}{c}\text { Fábrica de } \\
\text { Ladrilhos (1936) }\end{array}$ \\
\hline 1955 & Vila São Gabriel & 10,0 ha & Leonardo Petrilli & $\begin{array}{c}\text { Fábrica de } \\
\text { Bebidas (1936) }\end{array}$ \\
\hline 1955 & $\begin{array}{l}\text { Vila São João } \\
\text { Batista }\end{array}$ & 20,5 ha & Leonardo Petrilli & $\begin{array}{c}\text { Fábrica de } \\
\text { Bebidas (1936) }\end{array}$ \\
\hline 1958 & $\begin{array}{c}\text { Cidade } \\
\text { Universitária }\end{array}$ & 37,00 ha & Irmãos Crnkovic & $\begin{array}{l}\text { Curtume e } \\
\text { fábrica de } \\
\text { calçados }\end{array}$ \\
\hline 1969 & $\begin{array}{c}\text { Vila Monte } \\
\text { Carlo }\end{array}$ & 24,5 ha & Leôncio Zambel & $\begin{array}{l}\text { Extração de } \\
\text { pedras para } \\
\text { construção }\end{array}$ \\
\hline
\end{tabular}

Fonte: Elaborado pelo autor com base em: LIMA, 2007; ABREU, 2000; PREFEITURA MUNICIPAL DE SÃO CARLOS. Livro de impostos sobre indústrias e profissões para o ano de 1948. São Carlos: Fundação Pró-Memória de São Carlos. 
A década de 1950 é o período em que se intensifica o crescimento da área loteada, com 43 empreendimentos e uma área total de 751,2 hectares (ver mapa 15 no capítulo 02). Em relação às duas décadas anteriores, a participação dos industriais no total da área parcelada diminui significativamente, conforme pode ser observado na tabela abaixo e no quadro 01. Do total da área loteada, 28,5 foi implantada por industriais. Nessa década, os loteamentos se dispersam pela cidade seguindo as avenidas que ligam à atual rodovia Washington Luís, portanto, não mais sendo polarizado pela localização das indústrias.

Entre 1948 e 1958, ou seja, quando se acelera a implantação dos loteamentos, além dos industriais, muitos comerciantes se inserem no ramo imobiliário. Dos 49 loteamentos implantados, 13 foram realizados por industriais, como mostra Abreu (2000:91) e 13 foram realizados por comerciantes. Isto é, considerando ambos como integrantes do processo amplo da industrialização, e não apenas como instalação unidades industriais, podemos inferir que mais da metade (53\%) de um total de 49 loteamentos foram implantados por agentes ligados ao processo de industrialização.

Como se observa nos gráficos a seguir (quadro 05), na década de 1960 houve desaceleração da implantação de loteamentos. Foram implantados 406,5 hectares, sendo que apenas $6 \%$ foi realizado por industrial. Apenas o industrial Leôncio Zambel implantou um loteamento, na zona sul da cidade. Inclusive esse personagem revela a ligação estreita existente entre poder público, indústria, comércio e loteamentos, pois além de atuar na indústria no ramo de construção civil e metalúrgica, Leôncio Zambel foi presidente da ACISC (Associação do Comércio e Indústria de São Carlos), vereador e, em 1969, implantou o loteamento Vila Monte Carlo com 24,5 hectares. 


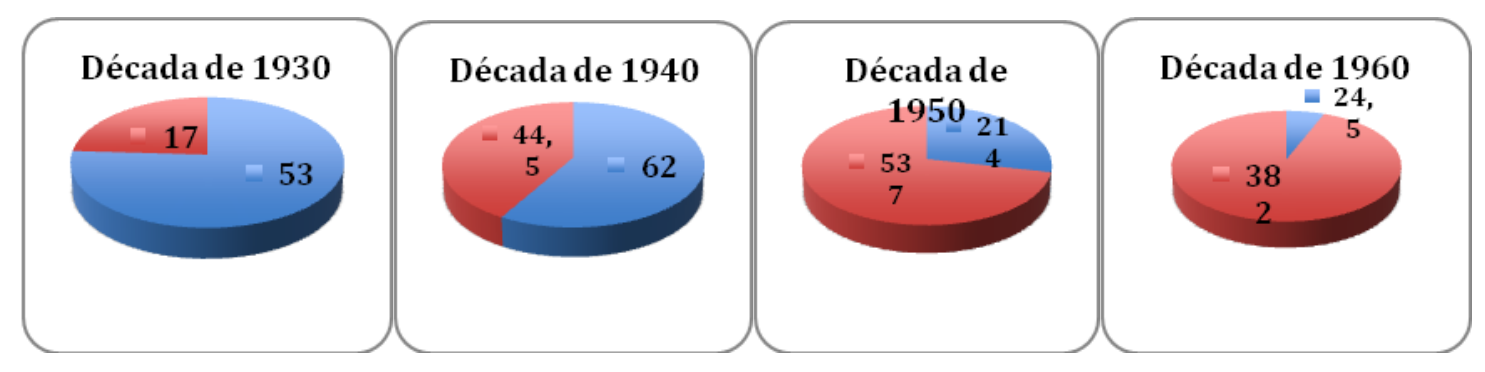

\section{Entre 1930 e 1969}

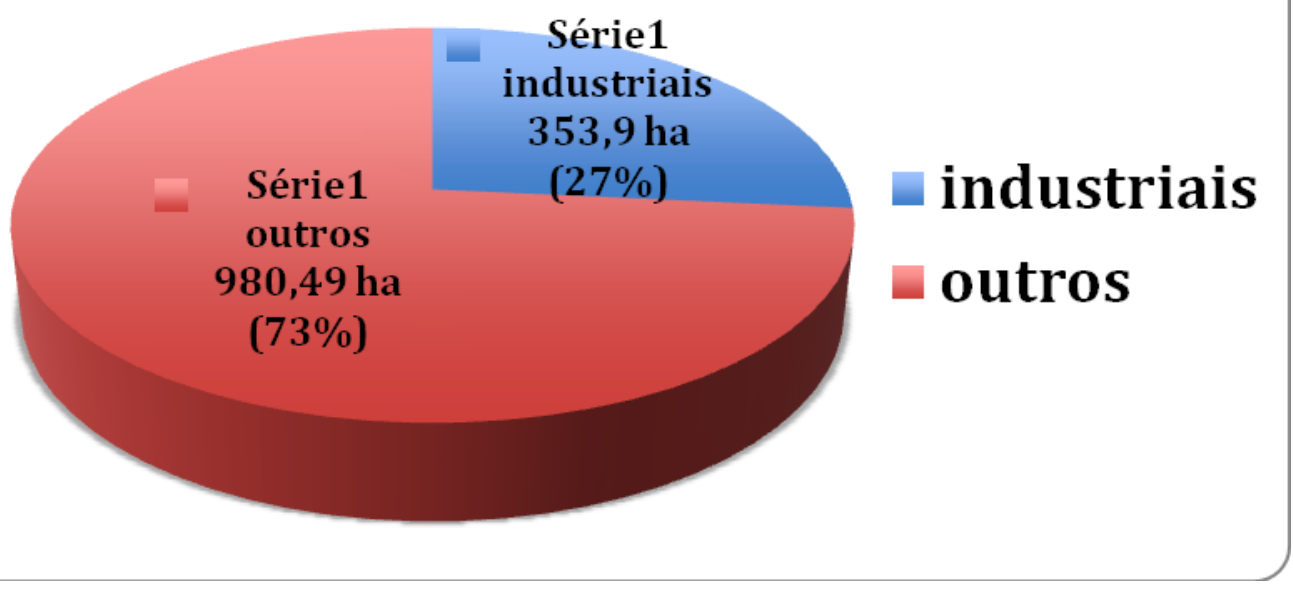

Quadro 05: Área em hectares e agentes da implantação de loteamentos em São Carlos entre 1930 e 1969.

Fonte: PREFEITURA MUNICIPAL DE SÃO CARLOS. Livro de impostos sobre indústrias e profissões para o ano de 1948. São Carlos: Fundação Pró-Memória de São Carlos; LIMA, 2007; ABREU, 2000.

Em entrevista realizada com Ítalo Cardinali Filho $^{26}$, constatamos que os próprios industriais compravam as terras e implantavam os loteamentos. No caso da família Cardinali, que fundaram a Indústria e Comércio Cardinali em 1964, Ítalo C. Filho conta que, como a indústria da família cresceu bastante, seu pai decidiu comprar fazendas ao redor da cidade e realizar loteamentos, fundando a Imobiliária Cardinali, em 1974. No entanto, a atuação da família no ramo industrial começou bem antes da fundação da Indústria Cardinali.

A indústria começou através de Giácomo Cardinali (bisavô de Ítalo C. Filho), que chegou da Itália em 1901 e começou a trabalhar com conserto de bicicletas. Os dois filhos de Giácomo, Eugênio (avô de Ítalo C. Filho) e Núncio, a partir das bicicletas, montaram uma oficina de automóveis, como mostra a figura 25.

\footnotetext{
${ }^{26}$ Realizada em 30/06/2014 com Ítalo Cardinali Filho, empresário do ramo imobiliário em São Carlos.
} 


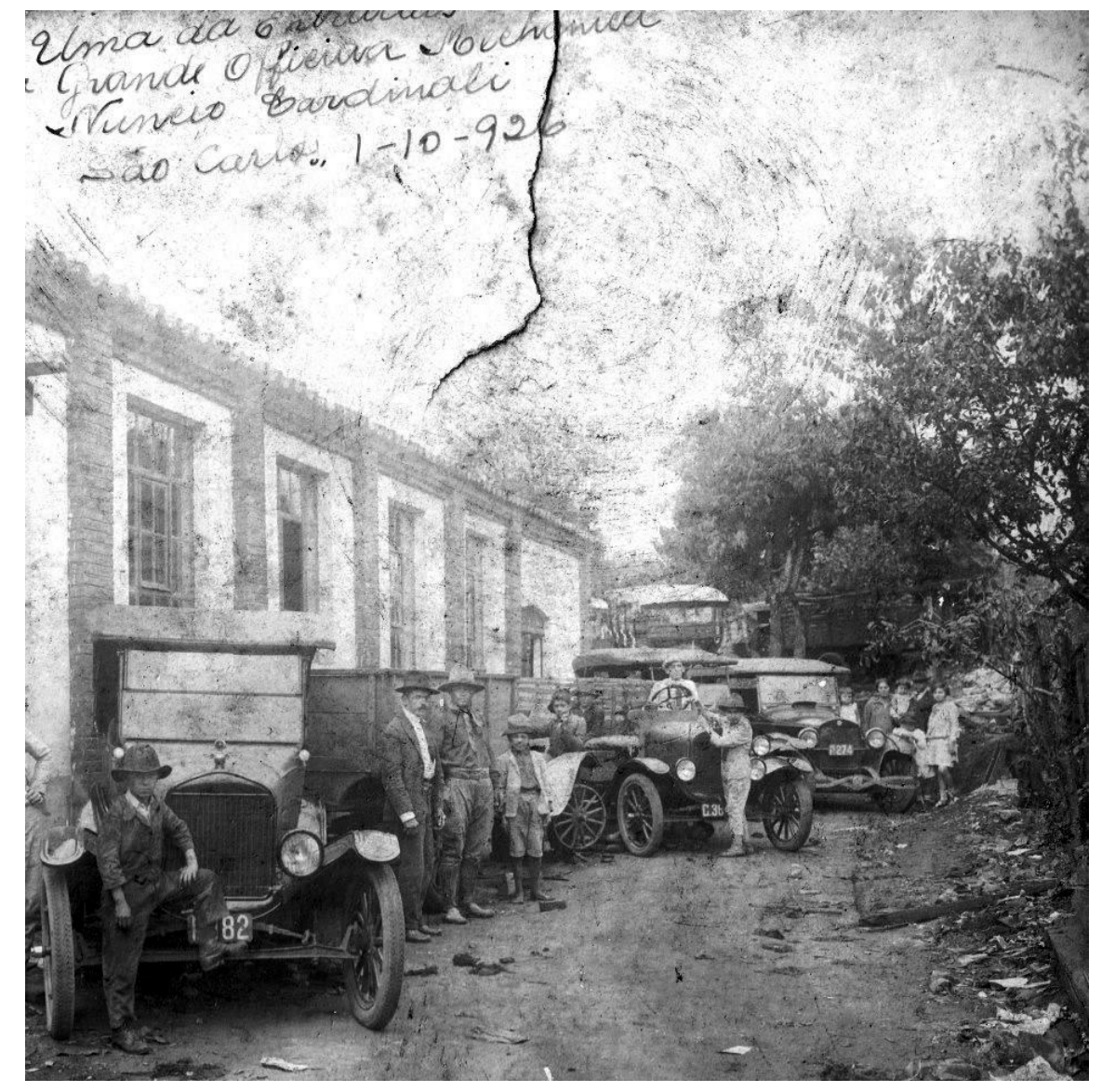

Figura 25: Oficina Mecânica de Núncio Cardinali, 1926.

Fonte: Prefeitura Municipal de São Carlos. Fundação Pró-Memória

Eugênio se separou de Núncio e montou um posto de gasolina e uma oficina de automóveis da Studebaker, ambos de propriedade do avô de Ítalo. Foi no fundo da oficina da Studebaker que o pai de Ítalo C. Filho começou a indústria, com o apoio do avô, que entrou como sócio e deu um aporte maior de capital para a indústria. Assim, nasceu a Indústria e Comércio Cardinali, que no início era uma recuperadora das sucatas de plástico das geladeiras Clímax fabricadas pela IPL. A partir de então, começou a produzir as peças de plásticos das geladeiras e fornecer para IPL. Quando começaram a chegar geladeiras importadas com portas sem maçanetas e com ímãs, a Indústria Cardinali desenvolveu o primeiro ímã de geladeira fabricado no Brasil. Posteriormente, passou a fornecer para outras empresas de geladeiras. A indústria (do setor de bens de produção) cresceu e diversificou sua produção, se inserindo também no setor de bens de 
consumo, com fabricação de tubos e conexões. Posteriormente, ficou conhecida por esse ramo embora sua maior produção fosse para outras indústrias.

Portanto, percebe-se que a origem da Imobiliária Cardinali remonta ao início da industrialização em São Carlos, quando foram acumulando capital com a indústria, comprando terras ao redor da cidade e posteriormente as loteando. Como não foi possível realizar entrevistas com os loteadores mais antigos, esse procedimento de inversão de capital da indústria para o ramo imobiliário praticado por essa família ajuda a compreender como se dava a relação em períodos anteriores.

Segundo relata Ítalo C. Filho:

"Na década de 1970, realmente, se você for fazer um apanhado aí nas cinco, dez maiores indústrias de São Carlos, eram todas indústrias de são-carlenses, italianos, descendentes de italianos, portugueses, alemães, suíços, mas eram todos de São Carlos, e nessa década, realmente, ganhou-se muito, porque a indústria cresceu muito. E se você pegar essas quase dez empresas, todas investiram no setor imobiliário, comprando fazendas ao redor da cidade. Mas, o meu pai sempre gostou do ramo imobiliário. Em contrapartida, em 74, já com bastante áreas em volta da cidade ele abriu a imobiliária com o intuito não só de especular, como todo mundo fez guardando as áreas, meu pai já começou a fazer loteamento, então abriu-se a Imobiliária Cardinali com o primeiro empreendimento em 74 , do $J d$. Cardinali, depois disso veio uma série de loteamentos: Val Paraíso 1, 2, Martinelli e a gente continua loteando até hoje.(sic)"

Seguindo a entrevista, constatamos que era uma imobiliária pequena, que contava com cerca de apenas quinze pessoas empregadas, mas possuía todo o maquinário para fazer os loteamentos, como esteira, máquina retroescavadeira, lâmina, pá carregadeira, caminhões, etc.. Assim, a própria imobiliária fazia toda a infraestrutura. No início não era aberta a terceiros, trabalhavam apenas com os loteamentos e imóveis próprios, i.e, da Indústria Cardinali ou da família Cardinali e a venda dos loteamentos era passada para outras imobiliárias. O entrevistado ainda explica que era uma imobiliária mais empreendedora do que comercializadora, pois funcionava como um braço de investimento da indústria e uma poupança. 


\section{CONSIDERAÇÕES FINAIS}

\section{- Crescimento industrial e industrialização de 1930 a 1960}

Durante a fase em que a produção principal em São Carlos era o café, a cidade não era o local da produção, mas de consumo e de prestação de serviços. As cidades que cresceram nessa conjuntura desempenhavam função de entreposto comercial e administrativo (público e privado) da produção agrícola para o mercado internacional. Ao mesmo tempo, por ação da dialética histórica, os imigrantes desenvolviam relações de produção capitalista produtiva e comercial, fazendo germinar um novo polo dinâmico (interno) na economia. No contexto nacional, São Carlos foi pioneira na produção industrial, assim como todo o estado de São Paulo, que se beneficiou do desenvolvimento do complexo cafeeiro, responsável por introduzir infraestruturas de transportes e energia, bancos, mão de obra livre e acumulação de pequeno capital comercial e industrial. Os imigrantes, sobretudo italianos, foram os pioneiros na instalação das primeiras indústrias e, posteriormente, conquistariam status na sociedade, tendo importante papel político.

A partir de 1930, novas condições políticas impulsionaram a indústria, sendo que a cidade de São Carlos havia reunido condições que possibilitaram a reorganização da atividade produtiva no rumo industrial: infraestrutura urbana, acumulação do pequeno capital comercial/industrial, disponibilidade de mão de obra e mercado consumidor interno. Com a crise do setor agrícola, devido à fase recessiva da economia mundial que entrou em colapso em 1929, a indústria em São Carlos começou a se diversificar em gêneros e crescer em volume.

Durante as décadas de 1930 e 1940, São Carlos, a região metropolitana da capital e o estado de São Paulo, tiveram um crescimento industrial que caminharam de modo muito semelhante. Assim como em relação ao Brasil e ao estado de São Paulo, em São Carlos os setores que mais cresceram foram os de bens intermediários e de bens de consumo duráveis, devido principalmente ao crescimento dos ramos de construção e metal-mecânica (bens intermediários e de consumo duráveis) e mobiliário (bens de consumo duráveis). Apesar do crescimento desses ramos, no final da década de 1940, a maior parte da produção no estado de São Paulo em São Carlos ainda era representada por bens de consumo não duráveis, principalmente vestuário e alimentos (industrialização restringida). Ao longo dessas duas décadas, a produção industrial do 
estado de São Paulo se concentrou na capital, que teve taxas de crescimento mais elevadas que o interior do estado.

Nas décadas de 1950 e 1960 começa a industrialização propriamente dita, quando se instalam indústrias de grande porte votadas para a fabricação de bens de consumo duráveis e bens de capital. No ano de 1965, os ramos mais representativos para o total da produção industrial eram, por ordem, metal-mecânica, alimentação e vestuário, seguidos por diversão-educação-comunição (devido principalmente à indústria Johan Faber e às gráficas), mobiliário, construção e química.

Assim, o setor industrial mais importante em São Carlos no ano de 1965 ainda era o de bens de consumo não duráveis (alimentos, vestuário e artigos de educação e comunicação), seguido por bens de consumo duráveis (móveis e eletrodomésticos), bens intermediários (construção e produtos para construção) e bens de capital (máquinas para indústria e agricultura).

\section{- O processo de industrialização assume a forma da urbanização}

Quando se intensifica a substituição de importações e ocorre uma ruptura estrutural com o modelo de economia colonial, inicia-se o processo de independência econômica ao centro dinâmico, passando o setor produtivo a crescer em função do mercado interno. Ao mesmo tempo, a cidade deixa de desempenhar função supletiva à produção agroexportadora e torna-se o local da produção voltada para as necessidades da população local.

Adotando a conceituação de "urbano" como a dimensão mínima a partir da qual as atividades econômicas na cidade passam a servir às necessidades inadiáveis da população local, identificamos a formação do urbano em São Carlos durante a década de 1930, pois foi o momento de inflexão do crescimento da economia, que passou a crescer em função do mercado interno. Além da queda da produção de café e aumento da produção industrial, comércio e serviços, a partir de 1935, após longo tempo de estagnação, a área e a população urbana de São Carlos recomeça o crescimento.

Rapidamente, a cidade adquiriu outra função: passou a ser o local da produção, com a instalação de fábricas nas áreas centrais e a formação de bairros tipicamente industriais. O processo de crescimento econômico e urbano adquiriu outra lógica de acumulação e organização espacial, ou seja, não mais se dava no sentido de 
diversificação do complexo cafeeiro, mas para atender a atividade industrial voltada para o mercado interno. Com uma população majoritariamente urbana, morar na cidade não era mais sinônimo de prestígio e poder, e sim onde morar nesta cidade, pois começou a se intensificar a segregação por classes socioeconômicas.

A população total de São Carlos passou de 51.620 habitantes em 1934, para 86.385 em 1970 (aumento de 67\%). A população urbana passou de 20.791 habitantes em 1934, para 76.681 em 1970 (aumento de 274\%). A população rural passou de 30.829 habitantes em 1934, para 9.704 em 1970 (diminuição de 68\%).

A área urbana em 1929 era de 423,5 hectares em 1934 e em 1969 passou para 1.753 hectares em 1969 (aumento de 325\%). Desse modo, a densidade demográfica em 1934 era de 49 hab./ha e em 1969 passou para 43,7 hab./ha.

O número de indústrias passou de 103 estabelecimentos em 1930, para 409 em 1969, representando um aumento de $297 \%$. Vale lembrar que o tamanho e a complexidade das indústrias, de um modo geral, também aumentaram. O crescimento do setor de comércio foi muito superior ao de indústrias. São Carlos possuía 225 estabelecimentos comerciais em 1930 e em 1969, 1.725 estabelecimentos, o que representa um aumento de $667 \%$.

\section{- Atividades urbanas sob influência do sistema de transporte: concentração, dispersão e segregação}

Primeiramente, entre 1930 e 1948, a expansão urbana ficou concentrada próxima às indústrias e ao sistema de transporte sobre trilhos. Os padrões urbanísticos até então preservavam o mesmo modelo do século XIX. A distribuição das atividades econômicas e das moradias no território se relacionaram de modo estreito, sob influência do sistema de transporte sobre trilhos, o principal meio de transporte da época. O comércio, os bancos e, principalmente, as indústrias se instalaram próximos à estação ferroviária e aos trilhos do bonde elétrico. As moradias, também sob influência da imobilidade dos trilhos, se instalaram próximas ao local de trabalho. Todos os loteamentos implantados até 1948 se localizaram próximos à estação ferroviária. O caso mais emblemático foi a Vila Bela Vista, o maior loteamento desse período, que foi implantado por dois sócios de uma fábrica de meias e passou a abrigar, em sua maioria, operários. Assim, nas décadas de 1930 e 1940, o trabalhador tinha a necessidade de residir perto do local de 
trabalho. A ocupação pelas indústrias e por loteamentos se concentrou próximos à estação ferroviária.

Posteriormente, a expansão urbana seguiu o direcionamento dos eixos rodoviários. Entre 1949 e 1969, a expansão urbana se dispersou pela periferia, sob a influência dos transportes rodoviários, que imprimem uma nova localização para as indústrias, e também do transporte por ônibus que permitem o acesso às moradias em lugares distantes. A flexibilização da legislação urbanística, nesse segundo momento, permitiu que se instalassem novos padrões urbanísticos, ocasionando segregação socioespacial.

O automóvel foi introduzido no interior paulista na década de 1920, mas foi somente no final da década de 1940 que se popularizou e as estradas de rodagem ganharam importância e exerceram influência na conformação do espaço urbano. Na década de 1950, ocorre a maior expansão urbana no município em conjunto com o desenvolvimento do sistema rodoviário intermunicipal e do sistema de transporte urbano por ônibus. As maiores indústrias implantadas nesse período buscaram nova localização, próxima aos eixos rodoviários. Os loteamentos se dispersaram pela periferia com clara separação dos moradores por renda. Este fato foi possibilitado pela flexibilização da legislação que permitiu a implantação de loteamentos com lotes menores e dotados de pouca infraestrutura.

\section{- Atuação dos agentes públicos e privados}

A relação entre industrialização e urbanização se expressa também na convergência dos agentes do processo. Nessas duas décadas, diversos empresários ligados à industrialização se inseriram no ramo imobiliário, comprando terras e implantando loteamentos. Esses empresários também se inseriram no poder público, que passou a atuar a favor das indústrias, no provimento de infraestruturas urbanas e na regulação e/ou incentivos para instalação de indústrias e de crescimento do espaço urbano.

Além de ingressarem no poder público, os industriais e comerciantes também tiveram participação direta ou indireta no processo de expansão urbana. Indireta, no sentido de que a oferta de empregos nas indústrias gerou aumento da população urbana e ampliação do setor de comércio e equipamentos urbanos voltados para indústria. E, diretamente, pois, com o acúmulo de capital por parte desses agentes ligados ao 
processo da industrialização, muitos diversificaram seu ramo de atuação, comprando terras e implantando loteamentos.

Ao longo das décadas de 1930 a 1960, a participação dos agentes ligados ao processo de industrialização no ramo imobiliário foi diminuindo gradativamente. Na década de 1960, apenas um loteamento foi implantado por empresário do ramo industrial. Se considerarmos que durante o processo de industrialização se intensifica a divisão social do trabalho e as empresas se profissionalizam e se especializam, verticalizando a inversão de capital, uma hipótese para explicar essa diminuição pode ser encontrada na especialização dos industriais em seus respectivos ramos.

Em relação ao poder público, mostramos que este atuou de forma pontual no incentivo ao desenvolvimento dos processos de industrialização e expansão urbana. A atuação se deu na forma de incentivos fiscais às indústrias e na provisão de infraestrutura e mão de obra qualificada. Até a década de 1947 a expansão urbana caracterizou-se por um crescimento lento, conservando o mesmo padrão do século XIX, com controle definido pelo Código de Postura de 1929. A partir de 1948, intensificou-se a implantação de loteamentos e na década de 1950 e 1960 a flexibilização da legislação urbanística permitiu que fossem implantados loteamentos com lotes menores, carentes de áreas institucionais e infraestrutura, gerando heterogeneidade do traçado urbano e aprofundando a segregação socioespacial. Na década de 1960, foi fortalecida a construção de órgãos de planejamento urbano. A atuação sobre o processo de industrialização ganhou coordenação técnica, gerando a lei municipal que delimitava a zona industrial na cidade e que, na década seguinte, culminaria na criação do Distrito Industrial, localizado às margens da rodovia Washington Luís. 


\section{REFERÊNCIAS BIBLIOGRÁFICAS}

AMADOR, Itamar Moraes. O Urbano em São Carlos - vinte anos de política urbana: 1960 - 1980. 1981. Dissertação (Mestrado) EESC - USP , São Carlos.

ABREU, Alzira Alves de / BELOCH, Israel. Dicionário Histórico-biográfico Brasileiro Pós 1930. Editora: Fgv / Cpdoc, 1984.

ABREU, Jonas Modesto. Política, economia e desenvolvimento urbano na cidade de São Carlos (1880-1960). 2000. Dissertação (Mestrado) - UFSCAR, São Carlos.

ABRIL S.A. CULTURAL. Nosso Século: 1900/1910. A Era dos Bacharéis. São Paulo: Círculo do Livro S.A., 1985.

AZEVEDO, Aroldo de. A cidade de São Paulo: estudos de geografia urbana. Sao Paulo: Cia. Ed. Nacional, 1958.

BAER, Werner. A industrialização e o desenvolvimento econômico do Brasil. 2. Ed. rev. e aum. Rio de Janeiro, Ed. Fundação Getúlio Vargas, 1975.

BRAGA, C. de C. (1984). Contribuição ao estudo da história e geografia da cidade e município de São Carlos do Pinhal. In: ALMANACH DE 1894. (Ed. Fac-sím.) Joaquim Augusto (Ed.). São Carlos, SP: EdUFSCar, 2007.

CANO, Wilson. Raízes da concentração industrial em São Paulo $-2^{\mathrm{a}}$ edição, $1^{\mathrm{a}}$ reimpressão - São Paulo: T. A. Queiroz, 1983.

, Wilson. Ensaio sobre a formação econômica e regional do Brasil. Campinas:

Unicamp, 2002.

CARDOSO, Fernando Henrique. Dependência e desenvolvimento na América Latina: ensaio de interpretação sociológica/ Fernando Henrique Cardoso e Enzo Faletto. $6^{\text {a }}$ edição. Rio de Janeiro: Zahar Editores, 1981. 
CARVALHO, Eder Aparecido. PSD, UDN E PTB, OS TRÊS GRANDES PARTIDOS

DA TERCEIRA REPÚBLICA. Revista eletrônica de ciências sociais Ano I, Edição 01, fev 2007.

COELHO, Sandro Anselmo. O Partido Democrata Cristão: teores programáticos da terceira via brasileira (1945-1964. Rev. Bras. Hist. vol.23 no.46 São Paulo 2003). Online version ISSN 1806-9347.

COSTA, Cláudia Silvana da. Os imigrantes e seus descendentes no poder local - o caso de São Carlos. (Dissertação de mestrado) São Carlos: UFSCAR, 2001.

DE DECCA, Edgar Salvadori. O Silêncio dos vencidos. $3^{\text {a }}$ edição, São Paulo: Brasiliense, 1986.

DEAN, Warren. A Industrialização de São Paulo. $4^{a}$ edição. Rio de Janeiro: Editora Bertrand Brasil S.A., 1991

Warren. Rio Claro: um sistema brasileiro de grande lavoura (1820-1920). Rio de Janeiro: Paz e Terra, 1977.

DEVESCOVI, Regina C. Balieiro. Urbanização e Acumulação: um estudo sobre a cidade de São Carlos. - São Carlos: EDUSFCar, 1987.

DRAIBE, Sônia Miriam. Rumos e Metamorfoses: Estado e industrialização no Brasil, 1930 - 1960. Rio de Janeiro: Paz e Terra, 2004.

FARIA, Philippe Ladela de. Apontamentos à história do município de São Carlos do Pinhal, 1904, in Almanáque de São Carlos 1905, 2007

FAUSTO, Boris. História do Brasil. 2ª edição. Editora EDUSP. São Paulo, 1995. Boris. A revolução de 1930: historiografia e história. 5a ed. São Paulo: Brasiliense, 1978 
Boris. Pequenos ensaios de história da república: 1889 - 1945. Cadernos

Cebrap10<http://www.cebrap.org.br/v1/template.php?area=7\&pagina=31\&item biblio=205\&lang=pt $>$.

Data de acesso: 10/07/2011

FELDMAN, Sarah. O Urbanismo que exige a vida moderna. Anais do XI Seminário de Histporia da Cidade e do Urbanimo. Vitória. UFES, 2010.

, Sarah. Planejamento e Zoneamento. São Paulo: 1947-1972. São Paulo: EDUSP/FAPESP, 2005.

FREYRE, Gilberto. Casa Grande \& Senzala: formação da família brasileira sob o regime de economia patriarcal. 14 edição. Rio de Janeiro: J. Olympio, 1969.

, Gilberto. Sobrados e Mucambos: decadência do patriarcado rural e desenvolvimento do urbano. 5 ed. Rio de Janeiro: J. Olympio, 1977.

FURTADO, Celso. Formação econômica do Brasil. 34 ed. São Paulo: Companhia das Letras, 2008.

, Celso. Um Projeto para o Brasil. Rio de Janeiro: editora Saga S.A., 1968.

GOMES, Maria Terezinha Serafim. O processo de reestruturação produtiva em cidades médias do Oeste Paulista: Araçatuba, Birigui, Marília, Presidente Prudente e São José do Rio Preto. Tese (Programa de Pós-Graduação em Geografia Humana) Universidade de São Paulo, 2007.

GRIMBERG, Maria Cláudia Nunes. A formação da indústria no interior paulista: um estudo sobre o papel do pequeno capital na industrialização de São Carlos. São Carlos: Fundação Pró-Memória de São Carlos, 2007.

HARVEY, David. A Produção Capitalista do Espaço. $2^{a}$ edição. São Paulo: Annablume, 2006.

IANNI, Octávio. Estado e planejamento econômico no Brasil. $5^{\text {a }}$ edição. Rio de Janeiro: Editora Civilização Brasileira S.A, 1991. 
LENIN, Vladimir Ilich. O Desenvolvimento do Capitalismo na Rússia: o processo de formação do mercado interno para a grande indústria. São Paulo: Abril Cultural, 1982.

LIMA, Renata Priore. O processo e o (des)controle da expansão urbana em São Carlos (1857-1977). Dissertação (Dissertação-Programa de Pós-Graduação em Arquitetura e Urbanismo. Área de concentração: Arquitetura, Urbanismo) - Escola de Engenharia de São Carlos da Universidade de São Paulo, 2007.

LORENZO, Helena Carvalho de. A década de 1920 e as origens do Brasil moderno/ Helena Carvalho de Lorenzo e Wilma Peres da Costa, organizadoras. São Paulo: Editora UNESP, 1998.

, Helena Carvalho de. Origem e crescimento da indústria na região “Araraquara-São Carlos” (1900-1970). São Paulo: USP, 1979.

MAMIGONIAN, Armen. "Notas sobre o processo de industrialização no Brasil”. In: Boletim do Departamento de Geografia da Faculdade de Filosofia, Ciências e Letras, n. 2, Presidente Prudente, São Paulo, 1969.

MARX, Karl. O Capital: Edição Resumida por Julian Borchardt. Rio de Janeiro: Zahar Editores S.A., 1982. Karl. Ideologia Alemã. Fondo de Cultura, Cidade do México, 1969.

MATTOS, Dirceu Lino de. O parque industrial paulistano. In: Azevedo, Aroldo de. A cidade de São Paulo: estudos de geografia urbana. Volume III: Aspectos da metrópole paulista. Sao Paulo: Cia. Ed. Nacional, 1958.

MELO, Marcus André. B. C. de. "O Estado, o Boom do Século e a Crise da Habitação: Rio de Janeiro e Recife (1937-1946)". In: Fernandes, A. F. \& Filgueiras Gomes, M. A. (orgs.) Cidade \& História, Salvador, UFBA/Anpur, 1992. 
MELO, Marcus André. Municipalismo, Nation-Building e a Modernização do Estado no Brasil. In Revista Brasileira de Ciências Sociais $\mathrm{n}^{\circ}$ 23, ano 8, outubro. São Paulo:1993.

MELLO, João Manuel Cardoso de. O capitalismo Tardio: contribuição da formação e d desenvolvimento da economia brasileira. São Paulo: editora Brasiliense S.A., 1982.

MONBEIG, Pierre. Pioneiros e Fazendeiros de São Paulo. 2a edição. Editora Hucitec Ltda, 1998.

MOURÃO, Paulo Fernando Cirino. A industrialização do Oeste Paulista: O caso de Marília. Presidente Prudente, 1994. Dissertação (Faculdade de Ciências e Tecnologia Universidade Estadual Paulista).

MÜLLER, N. L. A área central da cidade. In: Azevedo, Aroldo de. A cidade de São Paulo: estudos de geografia urbana. Volume III: Aspectos da metrópole paulista. Sao Paulo: Cia. Ed. Nacional, 1958.

NEGRI, Barjas. Concentração e Desconcentração Industrial em São Paulo. Campinas SP: Editora da UNICAMP, 1996.

NEVES, Ary Pinto das. (1984). São Carlos: Na esteira do tempo (Álbum comemorativo do centenário da ferrovia: 1884 - 1984). São Carlos, s/ed.

, Ary Pinto das. O Jardim Público de São Carlos do Pinhal. - São Carlos: EdUFSCar, São Paulo: Imprensa Oficial do Estado de São Paulo, 2007.

NOSELLA, Paolo, et al. Schola Mater: a antiga Escola Normal de São Carlos 19111933/ Paolo Nosella, Ester Buffa - São Carlos: EdUFSCar, 2002.

OLIVEIRA, Francisco de. A economia brasileira: crítica à razão dualista. $5^{\text {a }}$ edição. Editora Vozes Ltda. Petrópolis - RJ, 1987. 
, Francisco de. O Estado e o Urbano no Brasil. In: Espaço e Debates:

revista de estudos regionais e urbanos, jun/set 1982. São Paulo/SP: Nucleo de Estudos Regionais e Urbanos.

PAINO, José Roberto Andrade. Matizes de uma Luta: capítulos tenebrosos da história sindical, empresarial e política de São Carlos. A tirania e a crueldade da ditadura e a volta à democracia, depois de muito sofrimento - São Carlos: Suprema, 2002.

PENTEADO, A. R.; PETRONE, P. In: Azevedo, Aroldo de. A cidade de São Paulo: estudos de geografia urbana. Volume IV: Os subúrbios paulistanos. São Paulo: Cia. Ed. Nacional, 1958.

PEREIRA, Luiz Carlos Bresser. Empresários e administradores no Brasil. Editora Brasilense. São Paulo, 1974.

PETRONE, Pasquale. São Paulo no século XX. In: Azevedo, Aroldo de. A cidade de São Paulo: estudos de geografia urbana. Volume II: A evolução urbana. São Paulo: Cia. Ed. Nacional, 1958.

PRADO JUNIOR, Caio da Silva. História econômica do Brasil. São Paulo: Brasiliense, 2010.

RAMOS, Plínio de Abreu. Os partidos paulistas e o Estado Novo. Editora Vozes Ltda. Petrópolis - RJ, 1979.

RANGEL, Ignácio. A Inflação Brasileira. São Paulo: Editora Brasiliense, 1978. , Ignácio. “A história da dualidade brasileira". In: Revista de Economia Política. n. 4. Ed. Brasiliense, 1981. Ignácio. Economia: Milagre e Anti-Milagre. Rio de Janeiro: Jorge Zahar Ed., 1985.

RATTNER, Henrique. Industrialização e Concentração Econômica em São Paulo. Rio de Janeiro, Fundação Getúlio Vargas, Serv. De publicações, 1972. 
ROSSINI, Rosa Ester. Geografia e Gênero: a mulher na lavoura cafeeira paulista. Tese apresentada ao Departamento de Geografia da Faculdade de Filosofia, Letras e Ciências Humanas da Universidade de São Paulo. São Paulo, 1988.

SANTOS, Milton. A urbanização brasileira - São Paulo: HUCITEC, 1994. , Milton. Espaço e Método. $3^{\text {a }}$ edição. São Paulo: Editora Nobel, 1992. , Milton. Espaço e Sociedade (Ensaios). $2^{\mathrm{a}}$ edição. Petrópolis: Editora Vozes Ltda, 1982.

SINGER, Paul Israel. Desenvolvimento econômico e evolução urbana: uma análise da evolução econômica de São Paulo, Blumenau, Porto Alegre, Belo Horizonte e Recife. $2^{\circ}$ ed. São Paulo: Nacional, 1977.

SIMÃO, A. O voto operário em São Paulo. Revista Brasileira de Estudos Políticos, Belo Horizonte, n. 1., p. 130-141, 1956

TRUZZI, Oswaldo. Café e Indústria. São Carlos: 1850-1950 - São Carlos: EdUFSCar, 2000.

VILLAÇA, Flávio. Espaço intra-urbano no Brasil - São Paulo: Studio Nobel: FAPESP: Lincoln Institute, 2001. Flávio (1993) Uma Contribuição para a história do planejamento no Brasil. In DEAK, Csaba e SCHIFFER, Sueli R. (1999) O Processo de Urbanização no Brasil. São Paulo. EDUSP/FUPAM. 


\section{FONTES DOCUMENTAIS}

\section{- Sobre indústrias}

Atlas Censitário Industrial do Brasil, 1960. Rio de Janeiro: IBGE, 1965.

CATÁlOGO DAS INDÚSTRIAS DO ESTADO DE SÃO PAULO (exclusive o município da capital). São Paulo: D.E.E. 1943.

CADASTRO INDUSTRIAL 1965. Rio de Janeiro: Fibge, 1968

ESTATÍSTICA INDUSTRIAL. São Paulo: DEE., 1938/1939.

INSTITUTO BRASILEIRO DE GEOGRAFIA E ESTATÍSTICA. Cadastro Industrial: São Paulo em 1952. Rio de Janeiro: IBGE, 1952.

PIZA, Marcello. Os Municípios do Estado de São Paulo: informações interessantes. São Paulo: 1933.

PREFEITURA MUNICIPAL DE SÃO CARLOS. Livro de impostos sobre indústrias e profissões para os anos de 1930; 1934; 1938; 1942; 1946; 1948. São Carlos: Fundação Pró-Memória de São Carlos.

Produção Industrial do Estado de São Paulo, 1957. São Paulo: DEE. 1959.

SÃO PAULO (Estado) Departamento de Produção Industrial. Livro dos municípios do Estado de São Paulo. São Paulo: 1951.

VALliM, Pedro E.. Álbum dos municípios do estado de São Paulo. São Paulo: Diretoria de Propaganda e Publicidade, 1940.

\section{- Sobre São Carlos}

ALMANACH DE 1894. (Ed. Fac-sím.) Joaquim Augusto (Ed.). São Carlos, SP: EdUFSCar, 2007. (Coleção Nossa História). 
ALMANACH DE S. CARLOS PARA 1915. (Ed. Fac-sím.) Joaquim Augusto (Ed.). São Carlos, Sp: EdUFSCar, 2007. (Coleção Nossa História)

ALMANACH-album de São Carlos: 1916-1917. São Paulo: São Carlos, SP: Imprensa Oficial, EdUFSCar, 2007.

ALMANACK Annuario de São Carlos: 1928. São Paulo: São Carlos, SP: Imprensa Oficial, EdUFSCar, 2007.

ASSEMBLEIA LEGISLATIVA DO ESTADO DE SÃO PAULO, DECRETO N. 13.363, DE 12 DE MAIO DE 1943

ASSEMBLEIA LEGISLATIVA DO ESTADO DE SÃO PAULO, DECRETO N. 18.566, DE 7 DE ABRIL DE 1949

CÂMARA MUNICIPAL. Código de Postura do Município de São Carlos de 1866

CÂMARA MUNICIPAL. Código de Postura do Município de São Carlos de 1886

CÂMARA MUNICIPAL. Código de Postura do Município de São Carlos de 1902

CÂMARA MUNICIPAL DE SÃO CARLOS, LEI No 625, de 14 de janeiro de 1944

CÂMARA MUNICIPAL DE SÃO CARLOS, LEI Nº 983, de maio de 1948

CÂMARA MUNICIPAL DE SÃO CARLOS, LEI Nº 995 de 1948

CÂMARA MUNICIPAL DE SÃO CARLOS, LEI Nº 1134, de 1949

CÂMARA MUNICIPAL DE SÃO CARLOS, LEI N 1335, de 30 de dezembro de 1950

CÂMARA MUNICIPAL DE SÃO CARLOS, LEIS No 1360,1438 e 1456, de 1951

CÂMARA MUNICIPAL DE SÃO CARLOS, LEI No 1716, de 30 de abril de 1953 
CÂMARA MUNICIPAL DE SÃO CARLOS, LEI Nº 1946, de 23 de agosto de 1954

CÂMARA MUNICIPAL DE SÃO CARLOS, LEI No 4113 de 01 de novembro de 1960

CÂMARA MUNICIPAL DE SÃO CARLOS, LEI Nº 4411 de 30 de março de 1962

CÂMARA MUNICIPAL DE SÃO CARLOS, LEI No 4421 de 25 de abril de 1962

CÂMARA MUNICIPAL DE SÃO CARLOS, LEI No 4504 de 04 de setembro de 1962

CÂMARA MUNICIPAL DE SÃO CARLOS, LEI No 4709 de 22 de agosto de 1963

CÂMARA MUNICIPAL DE SÃO CARLOS, LEI No 5205 de 07 de maio de 1966

CÂMARA MUNICIPAL DE SÃO CARLOS, LEI Nº 5206 de 11 de maio de 1966

CÂMARA MUNICIPAL DE SÃO CARLOS, Setor de Recepção, Expedição e Registros de Documentos Oficiais. Arquivo.

GUIA DE INFORMAÇÕES DE SÃO CARLOS DE 1969. Tipografia Pinhal LTDA. São Carlos, 1969.

INSTITUTO BRASILEIRO DE GEOGRAFIA E ESTATÍSTICA. Censos Demográficos de 1940, 1950, 1960, 1970.

\section{- Jornais}

Correio de São Carlos, 13 de janeiro de 1938

Correio de São Carlos, 30 de janeiro de 1938 
Correio de São Carlos, 27 de fevereiro de 1938

Correio de São Carlos, 27 de fevereiro de 1938

Correio de São Carlos, 13 de março de 1938

Correio de São Carlos, 3 de maio de 1938

Correio de São Carlo, 15 de janeiro de 1942

Correios de São Carlos, 27 de junho de 1943

Correios de São Carlos, São Carlos, 27 de junho de 1943

Correio de São Carlos, 02 de fevereiro de 1950

Correio de São Carlos, 25 de maio de 1950

Correio de São Carlos, 06 de junho de 1950

Correio de São Carlos, 08 de Junho de 1950

Correio de São Carlos, 12 de fevereiro de 1955

Correio de São Carlos, 16 de fevereiro de 1955

Correio de São Carlos, 20 de fevereiro de 1954

Correio de São Carlos, 10 de junho de 1954

Correio de São Carlos, 3 de fevereiro de 1955

A Cidade, 27 de janeiro de 1962

A Folha, 10 de julho de 1966 
- Bases cartográficas

Título: Planta da Cidade de S. Carlos Conjuncto da Rede de Águas com remanejamento e prolongamento

Ano: 1930

Escala: $1: 5.000$

Autor: Joel Garcês

Fonte: http://www.arquivoestado.sp.gov.br/mapas.php (Data de acesso: novembro de 2013).

Título: Planta da Cidade de São Carlos. Estado de São Paulo

Ano: 1949

Escala: 1:10.000

Autor: Des. Jader Vaz

Fonte: http://www.arquivoestado.sp.gov.br/mapas.php(Data de acesso: novembro de 2013).

Título: Obras realizadas na administração Mario Maffei 1973 - 1976

Ano: 1976

Escala: 1:10.000

Fonte: PREFEITURA DE SÃO CARLOS

\section{- Sites sobre temas pesquisados}

www.seade.gov.br

http://www.arquivoestado.sp.gov.br/

http://geo.saocarlos.sp.gov.br/

http://www.al.sp.gov.br/repositorio/legislacao/lei/1949/lei-373-25.07.1949.html

http://www.portalk3.com.br/Artigo/ memoria/sao-carlos-foi-capital-nacional-dos-

alfaiates).

http://saocarlos.sp.senai.br/institucional/2299/0/historico

http://www.lugardotrem.com.br 
http://cpdoc.fgv.br

http://www.estacoesferroviarias.com.br

http://www.fleischmann.com.br/sobre/

http://www.al.sp.gov.br/ (Câmara Legislativa do estado de São Paulo)

http://www2.camara.leg.br/ (Câmara Legislativa Federal) 


\section{LISTA DE TABELAS}

01: Evolução da produção de energia elétrica no estado de São Paulo 30

02: Importações brasileiras com uma perspectiva da oferta global. .52

03: Evolução da produção industrial e da inflação entre 1958 e 1965 .53

04: Estabelecimentos comerciais instalados em São Carlos em 1894. .64

05: Estabelecimentos industriais instalados em São Carlos em 1894 .64

06: Indústrias Instaladas em São Carlos em 1940 com fundação anterior a 1930. 70

07: Área, população e produção agrícola em São Carlos, Araraquara, Rio Claro e Jaú, 1938.

08: Distribuição das propriedades por tamanho em São Carlos, Araraquara e Rio Claro, 1937 .74

09: Indústrias instaladas por ramos industriais em São Carlos: 1930, 1940 e 1948.......76

10: Imposto pago para a prefeitura por ramos industriais em São Carlos, 1930 e 1948.

11: Crescimento no número de estabelecimentos industriais em São Carlos: 1948 a 1965.

12: Número de operários por ramos nas indústrias instaladas em São Carlos em 1965.

13: Indústrias localizadas fora do perímetro urbano do município de São Carlos em 1965.

6

14: Presidentes e governadores de São Paulo e filiação partidária: 1948 a 1969

15: Produção das indústrias estrangeiras em relação ao total da produção industrial de origem privada em 1968 .

16: Composição da Câmara Municipal de São Carlos segundo a profissão dos vereadores, nas eleições de 1936 e 1947

17: Composição da Câmara Municipal de São Carlos segundo a profissão dos vereadores nas décadas de 1950 e 1960. 
18: Dirigentes do executivo e do legislativo de São Carlos nas décadas de 1950 e 1960.

19: Empresários industriais atuantes no parcelamento do solo em São Carlos nas décadas de 1930 e 1940.

20: Empresários industriais atuantes no parcelamento do solo São Carlos nas décadas de 1950 e 1960 160

\section{LISTA DE FIGURAS}

01: Primeiras estradas de ferro do Oeste Paulista............................................................25

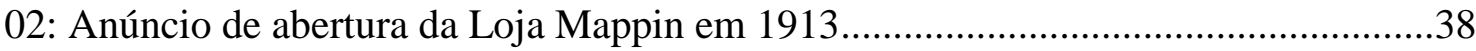

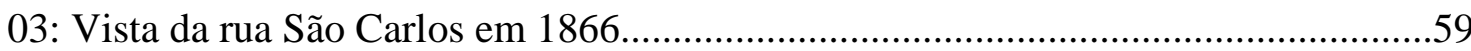

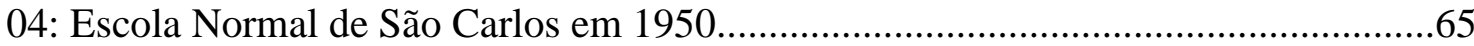

05: Infraestruturas de transporte em São Carlos até 1929.............................................66

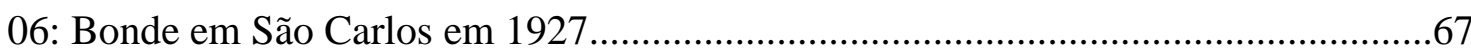

07: Banco de crédito internacional e depósito de secos e molhados em 1915................70

08: Anúncio loteamento Vila Monteiro, 1950...........................................................100

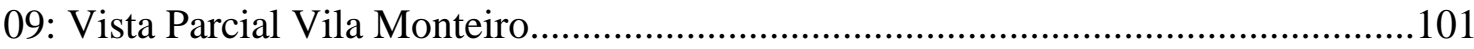

10: Construção de residência, Vila Monteiro, 1950......................................................101

11: Propaganda da primeira gleba do Loteamento Vila Monteiro, 1950.....................103

12: Sistema de transporte na região de São Carlos, 1938 ..............................................104

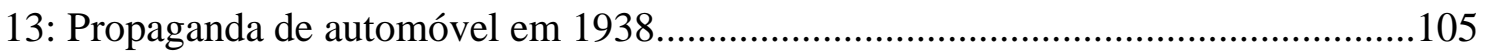

14: Propaganda de óleo para automóvel em 1938.....................................................106

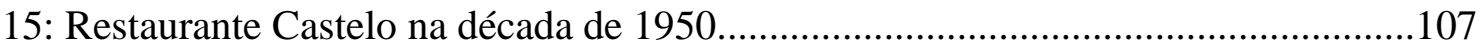


17: Proposta de estrada entre São Carlos e Bocaina em 1950.....................................108

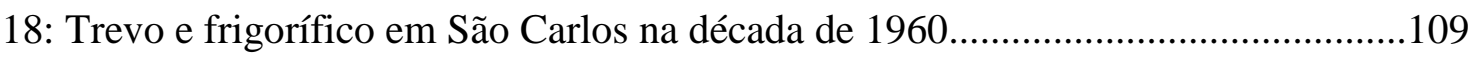

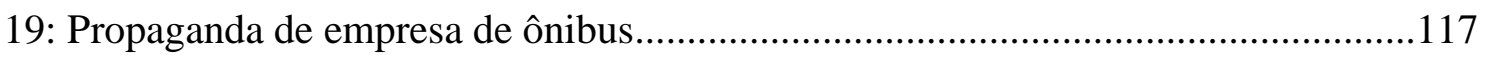

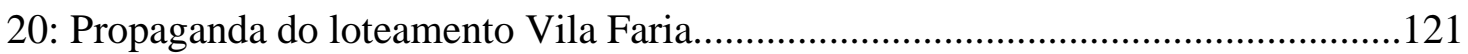

21: Desenho do loteamento Cidade Jardim: São Carlos, 1954_....................................124

22: Prédio E-1 da Escola de Engenharia de São Carlos, 1957.....................................147

23: Escola Industrial Paulino Botelho em São Carlos, 1933.......................................150

24: Unidade fabril da Fleischman em Jundiaí, 1954...................................................157

25: Oficina Mecânica de Núncio Cardinali, 1926.......................................................... 163

\section{LISTA DE MAPAS}

01: Localização das lavouras cafeeiras e ferrovias no início do século XX.

02: Localização das lavouras cafeeiras e ferrovias às vésperas da crise de 1929.

03: Capacidade de geração de energia elétrica no estado de São Paulo e localização das usinas $\mathrm{cm}$ mais de $1.000 \mathrm{HP}$.

04: Localização dos imigrantes que passaram pela Hospedaria dos Imigrantes de São

Paulo no período de 1898 a 1902.

05: Localização dos imigrantes que passaram pela Hospedaria dos Imigrantes de São Paulo no período de 1926 a 1930

06: Concentração da produção industrial no estado de São Paulo em 1930.

07: São Carlos área urbanizada em 1893.

08: São Carlos: Indústrias, área loteada e sistema de transporte em 1930 .89

09: São Carlos: Indústrias, área loteada e sistema de transporte em 1948. .92 
10: São Carlos: Atividades econômicas, expansão urbana e sistema de transporte em 1930.

11: São Carlos: Atividades econômicas, expansão urbana e sistema de transporte em 1948 .98

12: São Carlos: Indústrias e área loteada em 1965 113

13: São Carlos: Indústrias, bancos , sistema de transporte e área loteada em 1969......118

\section{LISTA DE QUADROS}

01: São Carlos: número de estabelecimentos industriais por ramos: 1930 e 1948 .75

02: São Carlos: número de estabelecimentos industriais por ramos 81

03: Indústrias com maior número de operários em São Carlos em 1965. .84

04: Indústrias com maiores valores de vendas em São Carlos em 1965 .85

05: Área em hectares e agentes da implantação de loteamentos em São Carlos entre 1930 e 1969 162 